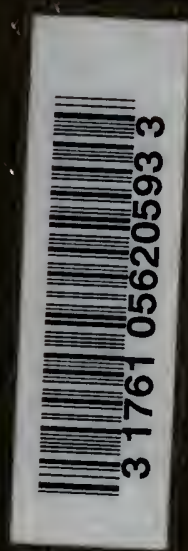






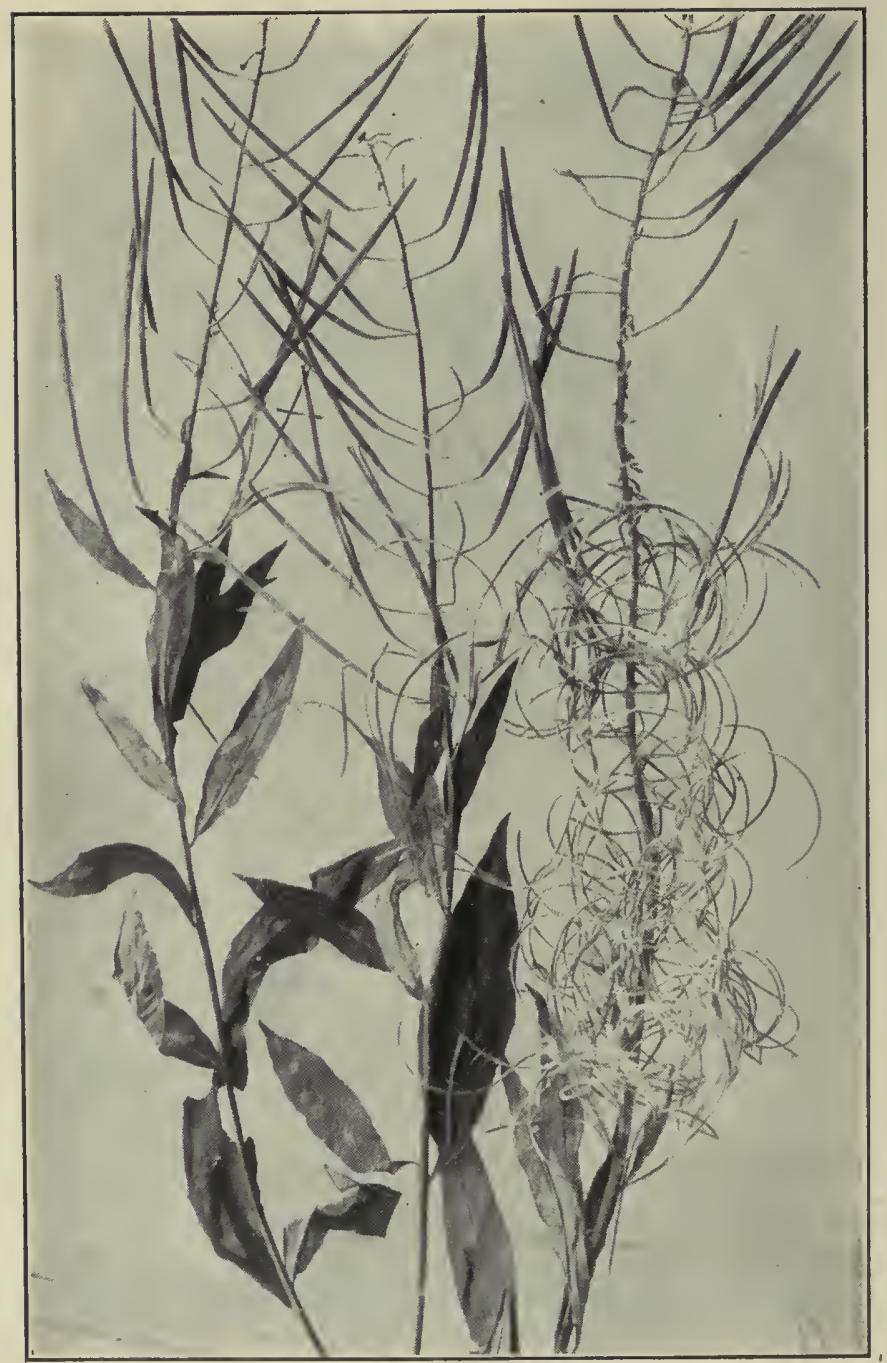

Great Western Fireweed (Epilobium angustifolium). A weed in clearings following fires, especially in the North, Rocky Mountains and the Pacific Coast. The seeds are carried by the wind. (Photograph by Charlotte M. King.) 
$\frac{B o}{P}$

\section{WEEDS OF THE}

\section{FARM AND GÁRDEN}

L. H. PAMMEL, B. Agr., M. S., Ph. D.

Professor of Bolany, Iowa Stale College, and Botanist Iowa Agricultural Experiment Station

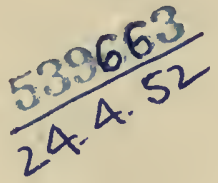

NEW YORK

ORANGE JUDD COMPANY

LONDON

KEGAN PAUL, TRENCH, TRÜBNER \& CO., Limited 


\author{
Copyright, 1911, by \\ ORANGE JUDD COMPANY \\ All Rights Reserved \\ ENTERED AT STATIONERS HALL \\ LONDON, ENGLAND
}

Printed in U.S.A. 
This work is dedicated to the Honorable Secretary of Agriculture, James Wilson, under whose auspices as Secretary of Agriculture, a great stimulus has been given to American Agriculture.

The Author 
Digitized by the Internet Archive in 2007 with funding from Microsoft Corporation 


\section{PREFACE}

There has long been needed a book describing the more important weeds of the United States, although there are numerous publications of the United States government and state experiment stations that treat of the more important weeds of the United States and Canada and their eradication. The demand for publications of this kind is so great that the editions soon become exhausted.

This work on weeds is here presented to bring some of the more important phases of the subject together in one treatise. Comparatively few books on this subject have been published in America. The treatise by Fletcher and Clark, and a second edition revised by Clark, treat the subject admirably. The work of Darlington and Thurber, "American Weeds and Useful Plants," found a welcome place in the botanists' library. The little book by Prof. Thomas Shaw also filled a most useful place in the agricultural literature of this country.

The weeds described in the present manual by no means cover all that are injurious, and we have described many more from eastern North America than from the Pacific coast or the southern states. In a work of limited scope it has been impossible to include more than a fraction of the weeds of the country. Those who are interested in a further study of the plants should provide themselves with such admirable manuals as the seventh Revised Edition of Gray's Manual by Robinson and Fernald, Nelson and Coulter's New Manual of Rocky Moun- 
tain Botany and Britton's Manual, Chapman's Flora of the Southern States, Small's Flora of the Southern States and a Flora of California soon to be issued by Professor Jepson.

The chapters on eradication of weeds, how weeds are disseminated, the farmer's interest in good seed, as well as the method of weed propagation, should be of special interest to the farmer. The illustrations should be helpful to those who are not familiar with the technical terms used in the descriptions of plants. Some of the figures were drawn by Miss Charlotte M. King, generally not indicated except by her initials, others by Miss Ada Hayden, all indicated except figures redrawn from other sources. To both I express my thanks for the artistic sketches. Many of the remaining figures have been taken from publications of the United States Department of Agriculture and the Iowa Agricultural Experiment Station. Credit has been given in every case. I am also greatly indebted to Miss Harriette S. Kellogg for the preparation of the bibliography, index, the reading of the manuscript and proof.

Ames, Iowa.

April 5, I9I I. 


\section{TABLE OF CONTENTS}

Chapter

Page

I. Weeds: Injury to Crops and Nature of.... I

II. Kinds of Weeds as to Duration......... 7

III. Dispersal of Weed Seeds............. I4

IV. The Farmer's Interest in Good Seed, and How to Test Seed............... 27

V. Weed Impurities in Agricultural Seeds..... 32

VI. Some Weed Laws and Seed-Control Laws.. 43

VII. Weeds of Special Crops............. 50

VIII. Poisonous Weeds................ $6_{3}$

IX. Table of Noxious Weeds............. $6_{5}$

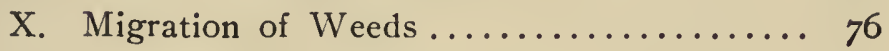

XI. Extermination of Weeds ............ 87

XII. Treatment for Special Weeds............ I04

XIII. Morphology of Weeds ............. II 4

XIV. Descriptions of Some Common Weeds...... I35

XV. Partial Bibliography, Consisting of Easily Accessible References, Arranged by Harriette S. Kellogg................. 255 



\section{LIST OF ILLUSTRATIONS}

Fireweed-Frontispiece

1. Canada Thistle Seed

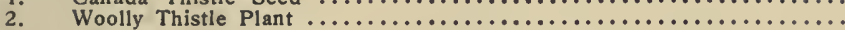

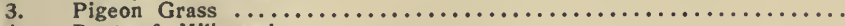

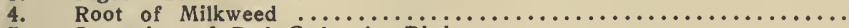

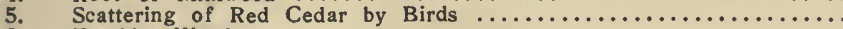

Tumble Weed

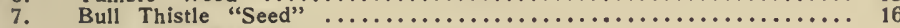

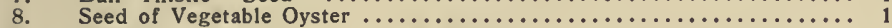

9. Ragweed Sunflower, and Foxtail Seeds $\ldots \ldots \ldots \ldots \ldots \ldots \ldots \ldots \ldots \ldots \ldots$

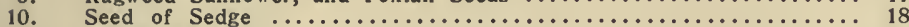

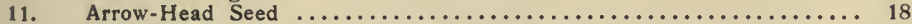

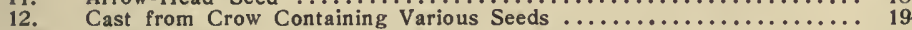

13. Goldfinch Eating Dandelion Seeds ........................ 20

14. Pod of Licorice; "Seed" of Cocklebur; Section of Carrot Seed ........ 20

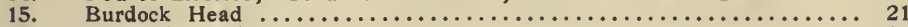

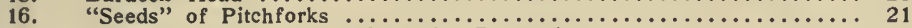

17. Seeds Scattered through Explosive Properties $\ldots \ldots \ldots \ldots \ldots \ldots \ldots \ldots \ldots \ldots 21$

18. Explosive Seeds and Fruits $\ldots \ldots \ldots \ldots \ldots \ldots \ldots \ldots \ldots \ldots \ldots \ldots \ldots \ldots \ldots \ldots 22$

19. Seeds Distributed with Wheat Seed $\ldots \ldots \ldots \ldots \ldots \ldots \ldots \ldots \ldots \ldots \ldots \ldots \ldots \ldots 23$

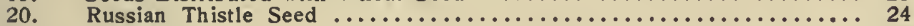

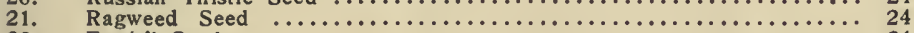

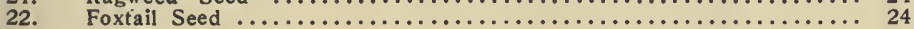

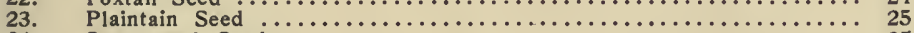

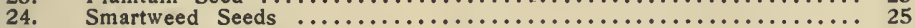

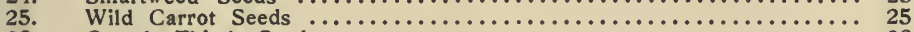

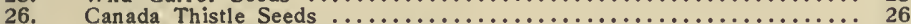

27. Impurities in Red Clover Seeds $\ldots \ldots \ldots \ldots \ldots \ldots \ldots \ldots \ldots \ldots \ldots \ldots \ldots \ldots \ldots \ldots \ldots . \ldots \ldots$

28. Red Clover and Sweet Clover Seeds $\ldots \ldots \ldots \ldots \ldots \ldots \ldots \ldots \ldots \ldots \ldots \ldots \ldots$

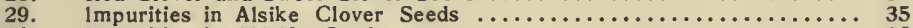

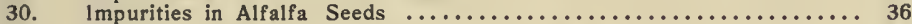

31. Seeds of Kentucky and Canadian Blue Grass $\ldots \ldots \ldots \ldots \ldots \ldots \ldots \ldots \ldots \ldots . \ldots$

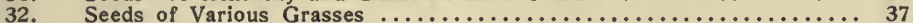

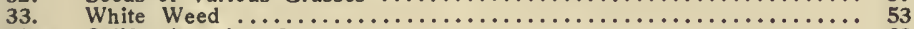

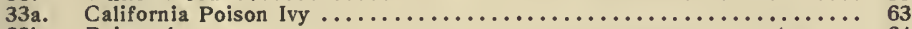

33b. Poison Ivy ...................................... 64

33c., 33d., 34., Maps Showing Distribution of Various Weeds ......77, 79, 82

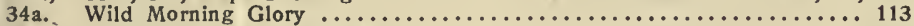

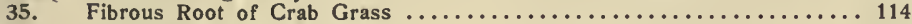

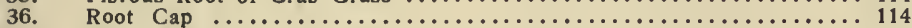

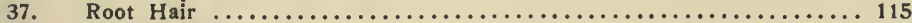

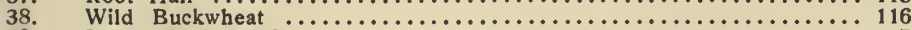

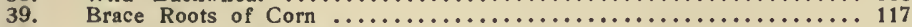

40. Cross-Section of an Endogenous Stem of $\mathrm{Com} \ldots \ldots \ldots \ldots \ldots \ldots \ldots \ldots \ldots \ldots \ldots$

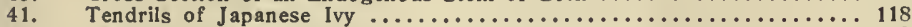

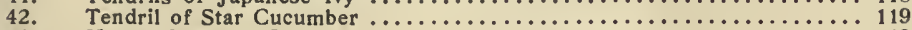

43. Horse Chestnut Leaf $\ldots \ldots \ldots \ldots \ldots \ldots \ldots \ldots \ldots \ldots \ldots \ldots \ldots \ldots \ldots \ldots \ldots \ldots \ldots \ldots 119$

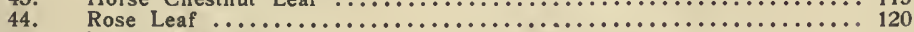

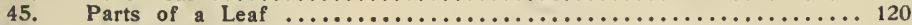

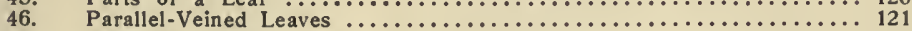

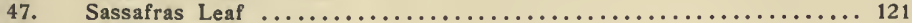

48. Aconite Leaf $\ldots \ldots \ldots \ldots \ldots \ldots \ldots \ldots \ldots \ldots \ldots \ldots \ldots \ldots \ldots \ldots \ldots \ldots \ldots \ldots \ldots \ldots \ldots \ldots \ldots \ldots$

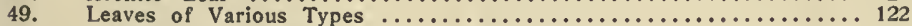

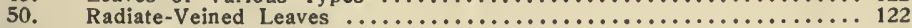

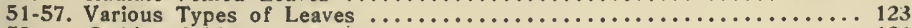

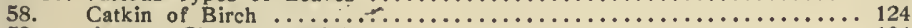

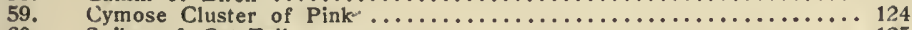

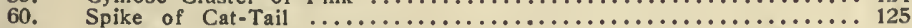

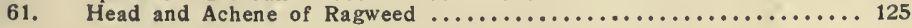




\begin{tabular}{|c|c|}
\hline RE & AG \\
\hline 62. & $\ldots \ldots \ldots \ldots \ldots \ldots \ldots \ldots \ldots \ldots \ldots \ldots \ldots \ldots, \ldots$ \\
\hline 6 & 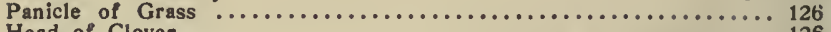 \\
\hline 6 & $\ldots \ldots \ldots \ldots \ldots \ldots \ldots$ \\
\hline & of Wild Lettuce $\ldots \ldots \ldots \ldots \ldots \ldots \ldots \ldots \ldots \ldots \ldots \ldots \ldots \ldots \ldots$ \\
\hline 3. & 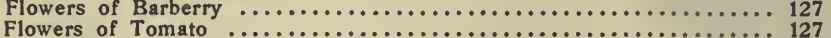 \\
\hline 3. & \\
\hline & conite Flower ...... \\
\hline & 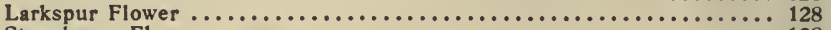 \\
\hline & 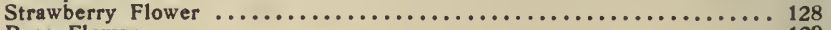 \\
\hline 73 & 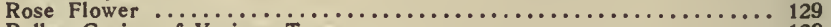 \\
\hline 74 & 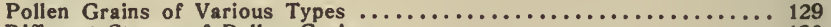 \\
\hline & erent Stages of Pollen Grains $\ldots \ldots \ldots \ldots \ldots \ldots \ldots \ldots \ldots$ \\
\hline & 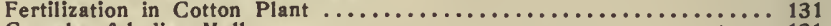 \\
\hline 77 & 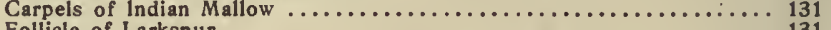 \\
\hline 78 & cle of Larkspur $\ldots \ldots \ldots \ldots \ldots \ldots \ldots \ldots \ldots \ldots \ldots \ldots \ldots \ldots \ldots \ldots$ \\
\hline & 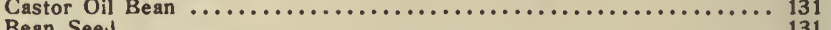 \\
\hline & 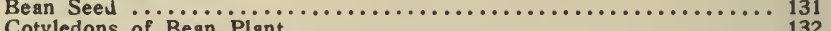 \\
\hline & 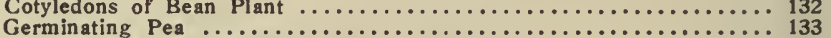 \\
\hline & 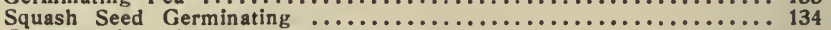 \\
\hline & -Section of Buckwheat Seed \\
\hline & - Section of Date Seed ..... \\
\hline & udinal Section of Kernel \\
\hline & on Brake $\ldots \ldots \ldots \ldots \ldots \ldots \ldots \ldots \ldots \ldots \ldots$ \\
\hline & 10oth Crab Grass $\ldots \ldots \ldots \ldots \ldots \ldots \ldots \ldots \ldots$ \\
\hline & een Foxtail .......... \\
\hline & rgia racemosa ..... \\
\hline & Grass $\quad \ldots \ldots \ldots \ldots \ldots \ldots \ldots \ldots \ldots \ldots \ldots \ldots \ldots \ldots \ldots \ldots \ldots \ldots$ \\
\hline & urass $\quad \ldots \ldots \ldots \ldots \ldots \ldots \ldots \ldots \ldots \ldots \ldots \ldots \ldots \ldots \ldots \ldots \ldots \ldots \ldots \ldots \ldots$ \\
\hline & 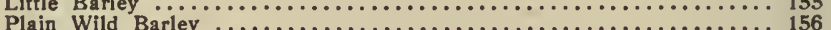 \\
\hline & 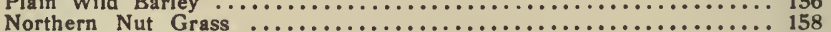 \\
\hline & 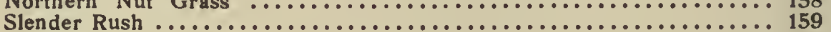 \\
\hline & ion Nettle $\cdots$ \\
\hline & 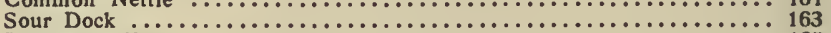 \\
\hline & 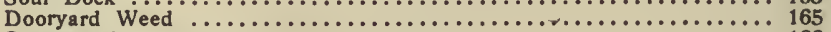 \\
\hline & 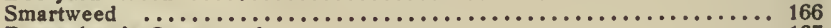 \\
\hline & 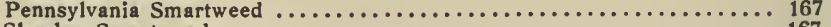 \\
\hline & nartweed....... \\
\hline & igweed..$\ldots \ldots \ldots$ \\
\hline & $\ldots \ldots \ldots \ldots \ldots \ldots \ldots \ldots \ldots \ldots \ldots \ldots \ldots \ldots$ \\
\hline & $\ldots \ldots \ldots \ldots \ldots \ldots \ldots \ldots \ldots \ldots \ldots$ \\
\hline & $\ldots \ldots \ldots \ldots \ldots \ldots \ldots \ldots \ldots \ldots \ldots \ldots \ldots$ \\
\hline & 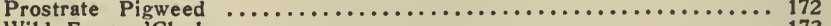 \\
\hline & 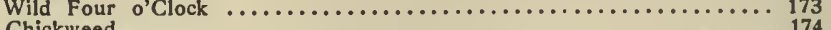 \\
\hline & $\ldots \ldots \ldots \ldots \ldots \ldots \ldots \ldots \ldots \ldots \ldots \ldots$ \\
\hline & $\cdots$ \\
\hline & Cockle $\ldots \ldots \ldots \ldots \ldots$ \\
\hline & •..... \\
\hline & $\because$ \\
\hline & \\
\hline & Grass. \\
\hline & n Mustard \\
\hline & Mustard .... \\
\hline & $\ldots \ldots 185$ \\
\hline & .... \\
\hline & 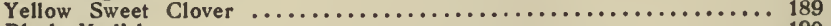 \\
\hline & 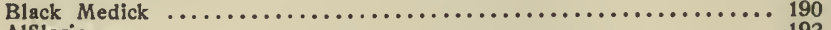 \\
\hline & $\ldots \ldots \ldots \ldots \ldots \ldots \ldots \ldots \ldots, 19$ \\
\hline & $\ldots \ldots \ldots \ldots \ldots \ldots \ldots \ldots \ldots$ \\
\hline & $\ldots \ldots \ldots$ \\
\hline & g Spurge ..... \\
\hline & \\
\hline
\end{tabular}


Balloon Vine

Butterprint

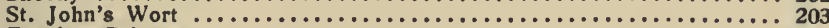

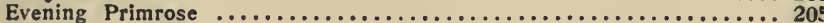

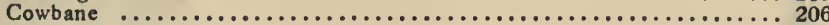

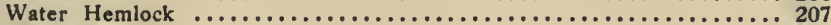

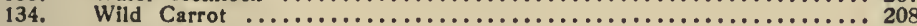

135.

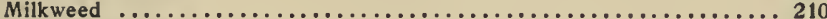

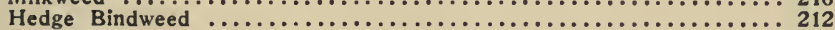

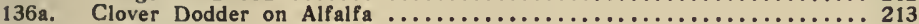

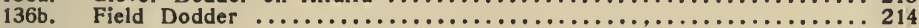

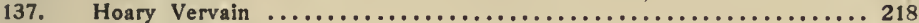

138. Dead Nettle $\ldots \ldots \ldots \ldots \ldots \ldots \ldots \ldots \ldots \ldots \ldots \ldots \ldots \ldots \ldots \ldots \ldots \ldots \ldots \ldots \ldots \ldots \ldots \ldots . \ldots 219$

139. Black Nightshade .................................... 220

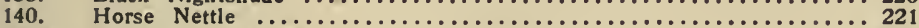

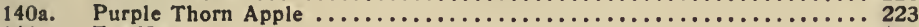

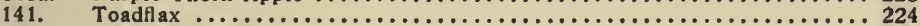

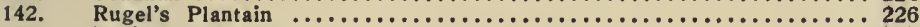

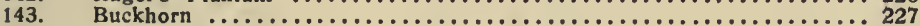

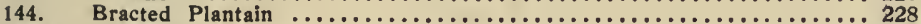

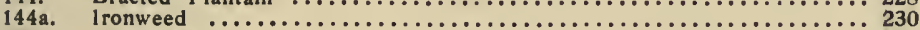

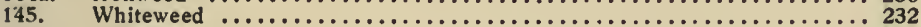

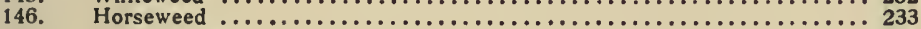

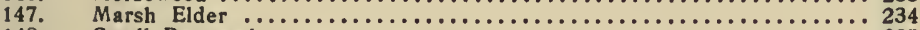

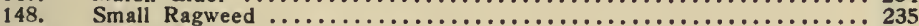

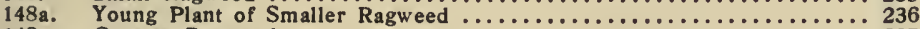

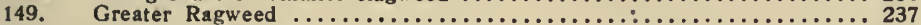

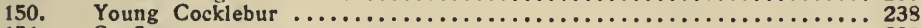

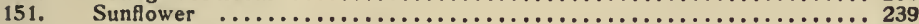

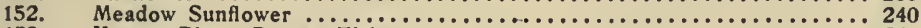

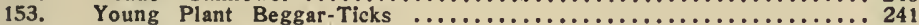

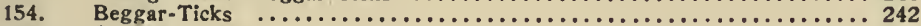

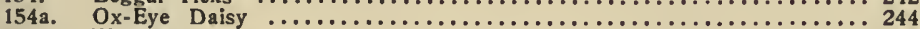

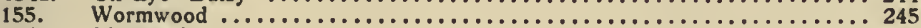

156. Fireweed $\ldots \ldots \ldots \ldots \ldots \ldots \ldots \ldots \ldots \ldots \ldots \ldots \ldots \ldots \ldots \ldots \ldots \ldots \ldots \ldots \ldots \ldots \ldots \ldots$

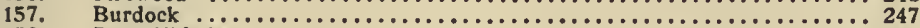

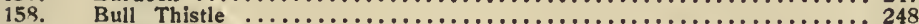

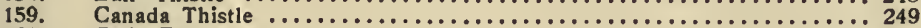

160. Cat's Ear $\ldots \ldots \ldots \ldots \ldots \ldots \ldots \ldots \ldots \ldots \ldots \ldots \ldots \ldots \ldots \ldots \ldots \ldots \ldots \ldots \ldots \ldots \ldots \ldots \ldots \ldots 251$

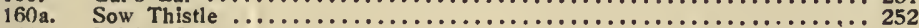

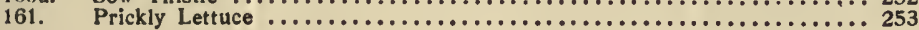





\section{CHAPTER I}

\section{WEEDS: INJURY TO CROPS AND NATURE OF}

What Is a Weed?-A weed has been defined as a plant out of place. If we accept this definition, pumpkins growing in a cornfield, if they are not wanted, are weeds; oats and barley growing in with wheat are to be regarded as weeds. Perhaps we may define "weed" by saying that it is a plant injurious to agriculture and horticulture, but I am reminded that many people have different notions in regard to weeds.

A great many people call every plant a weed the flower of which is not ornamental. The plants found in a forest would thus be regarded as weeds. As a matter of fact, these very plants found in the forest are important for the forest and cannot be regarded as weeds; they are a part of that particular plant community.

Weeds a Money Loss to the Farmer.-Weeds are of tremendous economic importance to all tillers of the soil. A crop shortage on many farms in this country is in part due to the growth of weeds. Farmers everywhere could increase their crops at least one-third by preventing the growth of weeds. The loss to farmers in every state would pay the taxes.

In the fall of 1908 the writer had some of his students make an estimate in different parts of the state of the injuriousness of weeds to a corn crop. It was found, for instance, that corn fields kept clean produced a one-third larger crop and that an estimate of the loss of corn from the growth of weeds in the state of Iowa amounts to $\$ 7,000,000$ to $\$ 9,000,000$ annually. In all of our great crop-producing states the losses are equally great. The injury from weeds in the United States is not far from 
$\$ 100,000,000$ annually. All of this could be prevented by applying better methods of cultivation. I have also had a very complete illustration that the removal of weeds increased the crop greatly in the case of a cornfield which contained a great deal of quack grass. In 1908 this field was cleaned and the present season has been in oats. The treated field contained one-third more oats to the acre than the weedy adjacent fields.

The same has been shown to be true also in some experiments made by Professors Edson and Eaton, for Vermont; they report not only a much larger yield but more fodder. The yield in fodder in some cases was two and one-fourth tons.

Why Weeds Are Injurious.-Weeds are injurious to the farmer because they exhaust the soil of the valuable nutrient material required for the crop. No one succeeds in obtaining a good yield of corn, wheat or other cultivated crop where weeds are allowed undisputed sway. The difference can be noticed at once when one farmer keeps his field clean and his neighbor allows weeds to grow. The one may obtain 60-70 bushels per acre from his field, while the latter has but thirty-five. Surely it does not pay to allow weeds to grow on land worth seventy-five or eighty or one hundred dollars per acre. Prof. H. L. Bolley says: "It is quite evident that if one sows enough seed wheat or other cereal to give a proper planting for the largest possible yield of grain, that it will not be possible to obtain this fullest yield if the ground already contains countless seeds of many sorts of weeds. One of the worst fallacies that is known to farming is indicated at this point. Almost every farmer knows some sort of weed which he thinks, or at least says he thinks, is of no harm to the wheat crop. For example, many persons have said French weed does not hurt the wheat crop, and many persist in saying that common mustard does not reduce the yield of wheat or 
oats. One might thus make a list covering practically all kinds of weeds. A peculiar feature is observed, however. It is never said of the weedy plant that it is not injurious to crop yield until it becomes so abundant on the man's farm or in a particular neighborhood that it seems practically impossible for the farmers concerned to get rid of it. It is then tolerated and finally the evil effects condoned in the manner indicated.

"A growing crop or plant gets its food material by absorbing the soil solutions. The excess of water is evaporated by the leaves. No more water is taken up by the crop than is evaporated by the leaves.

"If the leafy growth of a cereal crop is not normal in extent, but weakened and insufficient because of crowding out by other plants which exclude light and proper air supply, then the rate of water evaporation fron the leaves, and consequent absorption from the soil, will be greatly diminished. Thus even if there is an abundance of water and food materials, the cereal crop does not get its just supply if it is unduly crowded by other weedy growths. When drouthy times occur the weeds are able to do their greatest destruction."

"We have made many examinations of this question and have almost invariably come to the conclusion from our studies that where a normal stand of grain or other crop is upon the ground the yield of the crop will be found to be reduced in approximately direct proportion to the weeds which are developed on the ground during the growth season. This assumes that the water and soil conditions are normal. If, however, such conditions are abnormal during the maturing period of the crop, the loss in yield occasioned is often very much greater than that indicated. This is especially true if a drouthy time occurs just while the grain is filling."

A part of the depletion of our soils must be attributed to the growth of weeds on the farms, some weeds being 
much more exhaustive than others. We need conservation of the fertility of soil by preventing the growth of weeds.

Another reason why weeds are injurious, especially to young crops, is because they crowd out the useful plants. This is particularly true of such weeds as nut grass in our cornfields, mustard, at times, in oats and flax fields.

Some weeds are injurious because they are poisonous to man and the lower animals. Cowbane and water parsnip are powerfully poisonous; the seed of corn cockle poisons grain ; squirrel-tail, wild barley and awned brome grass are injurious because the awns work into the gums, causing serious inflammation and consequent loss of teeth.

Weeds are injurious because, on account of their presence, it is much harder to remove the crop. It is much more difficult to harvest wheat where Russian thistle is present. It is much more difficult to harvest small grain where wild buckwheat and morning glory occur. The spines of rose stems often inflict injury to persons obliged to shock and stack grain.

Weeds are frequently injurious because they harbor fungi. The well-known club root of cabbage occurs on mustard and on other allied plants; also on common pepper grass, and Dr. Halsted has shown that this is a frequent source of the disease on cabbage. Rust is often found on squirreltail grass. Professor Bolley says: "Weeds, because of their rank foliage, tend to keep the atmosphere cooler and moist, keeping the stems and foliage of the grain plants befogged with dew and other moisture when ordinarily it would remain comparatively dry. This accounts for the rust getting a stronger infection in the wheat fields than upon a clean, open crop. Later, when the grain is strongly attacked by the rust fungus and is in great need of water to keep up the supply which is being evaporated from the straw or stems where the rust has 
broken them open, the weeds cause the greatest damage by robbing the soil of the necessary moisture; the grain must, therefore, be shriveled in maturing."

Root rot of cotton is abundant on many plants, but especially so on members of the mallow family, as sida and shoofly. In this way this fungus is transmitted to cotton, sweet potato and the apple tree.

It is not unusual for owners of elevators to dock wheat containing a great deal of any weed seed proving difficult of removal, although the wheat itself might be graded No. I. The seed of kinghead cannot be taken out by the proper elevator machinery, hence the elevator men at Duluth decided that after August I, 1910, they would lock wheat that contained a great deal of kinghead. In the grain-growing states of the Dakotas and Minnesota, there is considerable dockage on account of weed seeds and the same is also true of the Canadian Northwest provinces. The loss to the farmers must amount to millions of dollars a year.

Certain weeds are injurious because when they become mixed with small grain, they must be removed before it can be sold as "A" wheat or oats, although all other conditions may be fulfilled. Where there is much mustard in oats, the grain will not bring so good a price as clean oats do, and the same may be said of wheat containing cockle, vetch, cow herb, garlic, sweet clover, etc.

Some Weeds Are Useful.-Weeds may in some cases serve some useful purpose. Digitalis is obtained from foxglove; hyoscyamine from black henbane; daturin from Jimson weed. Many weeds, like tansy and hemp, have medicinal properties. Others serve culinary purposes, as when the roots of chicory are used as a substitute for coffee. Lamb's quarter, dandelion and the young shoots of pokeweed are used as spring greens. The roots of tanweed or shoestring (Muhlenberg's 
smartweed) were formerly used in the process of tanning. The tubers of the cultivated artichoke are used as food, and the Indians used the wild artichoke in the same manner. The meadow sunflower was another plant that furnished food to the Indians. Sweet clover is an excellent bee plant, a good forage plant and a satisfactory soil renovator. Dr. Millspaugh states that many weeds possess good fertilizing properties. Weeds are of value if, when added to the soil, they give looseness and furnish a plant covering. Professor Bolley says: "The plant growths, consisting largely of common weeds and grasses which at once occupy idle land, keep it from becoming a useless dust bed and finally a mass of shifting sand. In shiftless and improper crop rotation the weeds and grasses which intervene may be looked upon as savers of soil quality. Those with tap roots bring up the substances from a greater depth than some of the ordinary crops; and by their varied characters introduce essential elements of proper crop rotation and in other ways reinstate the humus of the soil, which, by poor cropping methods, is often quickly removed. Under certain conditions large crops of weedy growths plowed under by shiftless farmers produce conditions of green manuring which, while not of the best type, are essential in preventing an entire loss of humus." 


\section{CHAPTER II.}

\section{KINDS OF WEEDS AS TO DURATION}

Weeds may be grouped with reference to their duration under the following classes: Annual, biennial, and perennial. An annual plant is one which germinates from seed in the spring, produces flowers and seed the same season, after the accomplishment of which it usually dies. Examples of annual weeds are foxtail, ragweed, and smartweed. The members of this class vary greatly. Some annuals approach biennial in habit and are called winter annuals.

Seeds of winter annuals germinate in the fall and produce a good growth until checked by frost. In the succeeding spring they make rapid growth, mature fruit, and die. Examples of winter annuals are speedwell, shepherd's purse, and chickweed.

The biennial plant, during the first season, produces vegetative growth only, this often consisting of a rosette of leaves close to

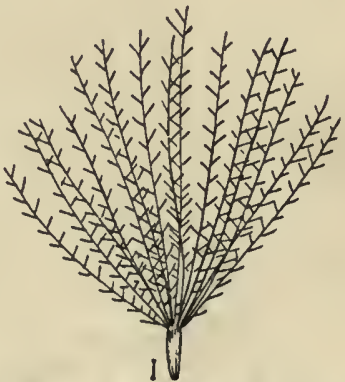

Fig. I. Canada thistle seed; a common source of spreading the weed. (C. M. King.)

the ground. In the second season, a flower stem is produced. Examples of biennial weeds are bull thistle, mullein, burdock, parsnip and carrot. Biennial weeds do not appear when the ground has been properly plowed.

The perennial plant has a natural existence of more than two years. These plants produce stems and roots which send up flower stalks year after year. Examples of this class are morning glory, milkweed, horse-nettle, and horse-radish. 
How Weeds Spread.-Weeds are spread by means of seeds, by vegetative reproduction, or by both seeds and vegetative reproduction.

Reproduction by Seeds.-Most weeds reproduce themselves by seeds. One of the exceptions to this rule is the

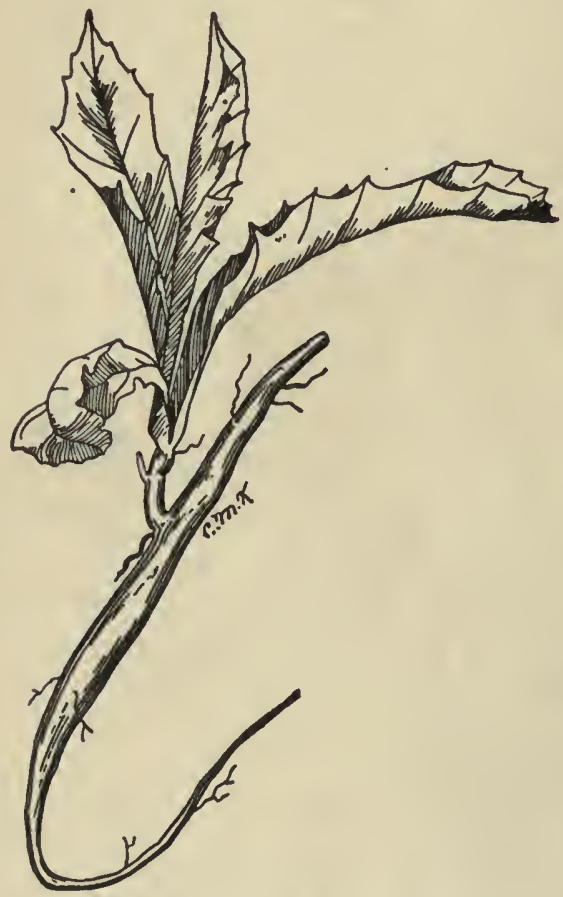

Fig. 2. Woolly thistle, a type of perennial root. quack grass, one
means of multiplication is by stems commonly called "roots," which are divided into a series of joints at which new shoots are produced. The same structure occurs in germander or wood sage. Horse-radish may be propagated by roots exclusively. In another type, like the does not, so far as we know, seed in Iowa.

It has been our observation that the Canada thistle usually does not seed in Iowa, although specimens of heads containing seed have been received from different parts of the state. It is also probable that the Canada thistle does not seed so frequently in Iowa or in the United States as in Europe.

Vegetative Reproduction. - M a n y weeds multiply by means of roots, stems, or both. In

horse-radish, which in

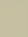


Canada thistle, morning-glory, and horse nettle, a small part of the underground portion is stem, the rest being

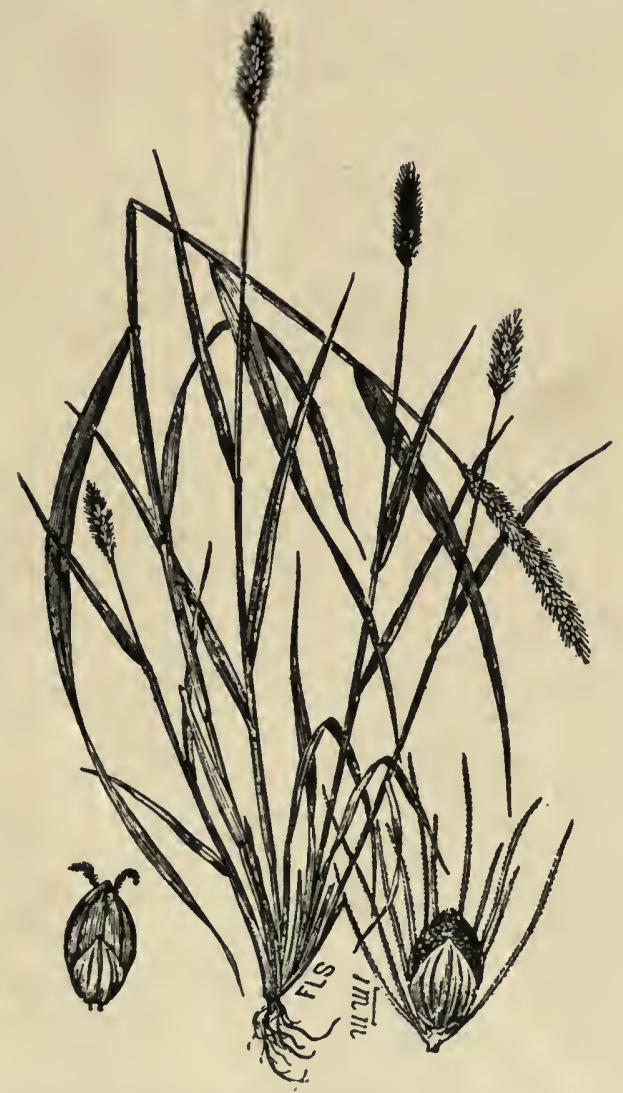

Fig. 3. Pigeon grass, a type of annual plant. (U. S. Dept. Agrl.)

true root. On these roots buds are produced which send up new shoots each year.

Some plants, like wild onion, produce bulblets. In others, as crab grass, the stem above the ground may 
strike root at the nodes, or roots may be produced at the joints, as in purslane.

These roots and stems, capable of producing new plants, are widely scattered in fields by means of the cultivator and plow. They may be dispersed with undecomposed manure, packing materials, or imported fruit trees. Mice and gophers may scatter roots to different parts of the field.

Character of Root Systems of Weeds.-The root systems of weeds vary greatly. The term root, as ordinarily used by the farmer, may mean a rootstock, as in the case of quack grass or nimble will. A great many weeds, especially perennials, have not only perennial roots but rootstocks also. A rootstock is simply a stem growing beneath the surface of the ground.

Many weeds have strong tap roots, this being especially true of biennial weeds like the Canadian lettuce, mullein, hemp, cocklebur, wild carrot, ragweed, prickly lettuce, pigweed, mayweed, lamb's quarter, bull thistle, and field thistle. The roots of many annual plants are fibrous and without any distinct tap roots. Moreover they are shallow, like those in the buckhorn, foxtail, plantain, yellow oxalis, and bootjack. The roots of plants in the same order may differ greatly, but their general habit depends a little on the character of the season. During moist seasons they become quite shallow, while after the season becomes drier, they descend obliquely. The common spurge (Euphorbia Preslii) has a straight taproot with horizontal roots near the surface of the ground which descend obliquely later. The common field thistle (Cirsium discolor) has a straight tap root with portions frequently enlarged bearing several more or less prominent lateral roots.

The cocklebur, which belongs to the same family, has a tap root which is considerably thickened near the surface of the ground, and which has large lateral roots. It 
may likewise produce a few nodal roots, but these are generally small and fibrous. The large ragweed ( $\mathrm{Am}$ brosia trifida) has a straight tap root with numerous small fibrous roots that descend obliquely into the lower strata of the soil. The horseweed of the same family has a straight tap root, numerous small fibrous roots, and one or more prominent lateral roots. These are at first horizontal, descending obliquely later.

The Spanish needle (Bidens frondosa) and its ally, stick-seed ( $B$. discoidea), are frequently found in moist places. Although they belong to the same family as the sunflower and ragweed, they do not ordinarily produce tap roots, but large lateral roots instead, which soon descend obliquely into the ground. The Canadian goldenrod (Solidago

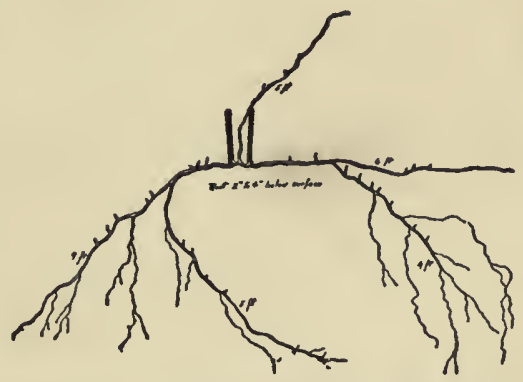

Fig. 4. Root of common milkweed, single root 14 feet long, with numerous lateral roots. The points indicate where new roots and stems are forming. Root method of spreading the weed. (C. M. King.) canadensis), with a horizontal rootstock, produces small lateral roots which soon begin to descend. The ox-eye (Heliopsis scabra), related to the goldenrod, also produces a rootstock from which grow fibrous roots, horizontal at first and then gradually descending. In the common mayweed of the same family the straight tap root produces numerous fibrous roots which descend obliquely. The buckhorn and plantain produce a large number of whitish, fibrous roots which are at first horizontal and then descend gradually into the soil. In some plants, as in cowbane, the roots are fascicled. In the wild parsnip and the garden parsnip the 
roots are conical. Common quack grass, wood sage, and peppermint produce numerous horizontal rootstocks that are found close to the surface of the ground, 75 per cent of the rootstocks being found within four inches of the surface. From the nodes there arise numerous small fibrous roots.

The roots of many perennial plants, like Canada thistle, morning-glory, horse nettle, and milkweed, spread extensively through the ground. The root of a common milkweed was traced by Mr. Garner and Mr. Lyle Clapper for a distance of 14 feet through the soil.

Dr. Byron D. Halsted, who made a study of the roots of various weeds, comments as follows concerning the character of roots: "By means of the root system most plants become anchored to the soil; therefore, other things remaining the same, among those species that live from year to year, the size of the root becomes an index of the persistency and pestiferousness of the plant." Then he comments upon the length of roots of a great many different weeds, stating that the common dandelion (Taraxacum officinale) had a root an inch in diameter and fifteen inches in length, but the writer has found a root of the dandelion more than four feet in length. It should be remembered also that in many cases when the root is injured near the top that a multiple root development follows. The burdock and dock frequently produce numerous roots when the plants are injured, although ordinarily these roots are straight and produce a single thick fleshy root. The characters of roots sometimes differ very materially in closely related species of plants. The common sour dock has a straight fleshy root, whereas the smooth or peach-leaf dock produces a number of branched roots, making it rather difficult to exterminate.

The following tables give the depth of roots and area covered by some of the common weeds. These figures 
indicate that the weeds may effectively rob the soil of many valuable constituents.

TABLE I

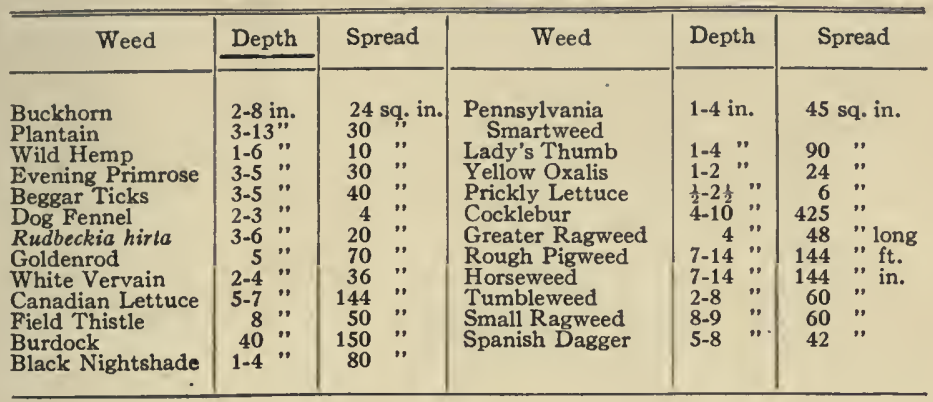

TABLE II

\begin{tabular}{|c|c|c|c|c|c|c|c|}
\hline Kind of weed & ¿े & 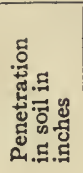 & 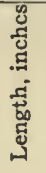 & Kind of weed & $\stackrel{\circ}{Z}$ & 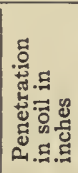 & 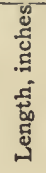 \\
\hline Quack Grass & $\begin{array}{r}1 \\
2 \\
3 \\
4 \\
5 \\
6 \\
7 \\
8 \\
9 \\
10 \\
11 \\
12 \\
13 \\
14 \\
15 \\
16 \\
17 \\
18 \\
19 \\
20 \\
21 \\
22 \\
23\end{array}$ & $\begin{array}{l}6 \\
4 \frac{1}{1} \\
5 \frac{1}{2} \\
5 \\
5 \frac{1}{3} \\
6 \\
5 \\
5 \frac{1}{2} \\
53 \frac{1}{2} \\
3 \\
3 \frac{1}{3} \\
2 \frac{1}{2} \\
3 \\
2 \frac{1}{2} \\
3 \\
3 \frac{1}{2} \\
3 \\
3 \\
2 \frac{1}{2} \\
4 \\
6 \\
8 \\
6\end{array}$ & $\begin{array}{r}32 \\
24 \\
34 \\
14 \\
18 \\
\\
16 \\
20 \\
\\
24 \\
\\
14 \\
12 \\
9 \\
56 \\
44\end{array}$ & $\begin{array}{l}\text { Quack Grass } \\
\text { Horse Nettle* }\end{array}$ & $\begin{array}{r}24 \\
25 \\
26 \\
27 \\
1 \\
2 \\
3 \\
4 \\
5 \\
6 \\
7 \\
8 \\
1 \\
2 \\
3 \\
4 \\
5 \\
6 \\
7 \\
8\end{array}$ & $\begin{array}{r}7 \\
7 \\
8 \\
6 \\
30 \\
29 \\
30 \\
27 \\
32 \\
30 \\
26 \\
36 \\
36 \\
42 \\
48 \\
36 \\
32 \\
30 \\
36 \\
32\end{array}$ & $\begin{array}{r}60 \\
38 \\
42 \\
30 \\
29 \\
30 \\
27 \\
32 \\
30 \\
26 \\
36 \\
48 \\
64 \\
60 \\
30 \\
39 \\
31 \\
108 \\
72\end{array}$ \\
\hline
\end{tabular}

*The roots of horse nettle extend straight down into the soil. 


\section{CHAPTER III}

\section{DISPERSAL OF WEED SEEDS}

Scattering of Plants.-After the seed is formed it must be placed in a congenial soil so that its kind may be perpetuated. This scattering of seeds and fruits is therefore important. The following are the different ways by which plants are scattered:

\section{WIND.}
A. Tumble weeds, Russian Thistle.
B. Winged fruit appendages, Maple.
C. Winged seed appendages, Milkweed.
D. Parts of inflorescence with modified expanded bracts, etc., Basswood.
E. Parts of the seed or fruit inflated, Balloon Vine.

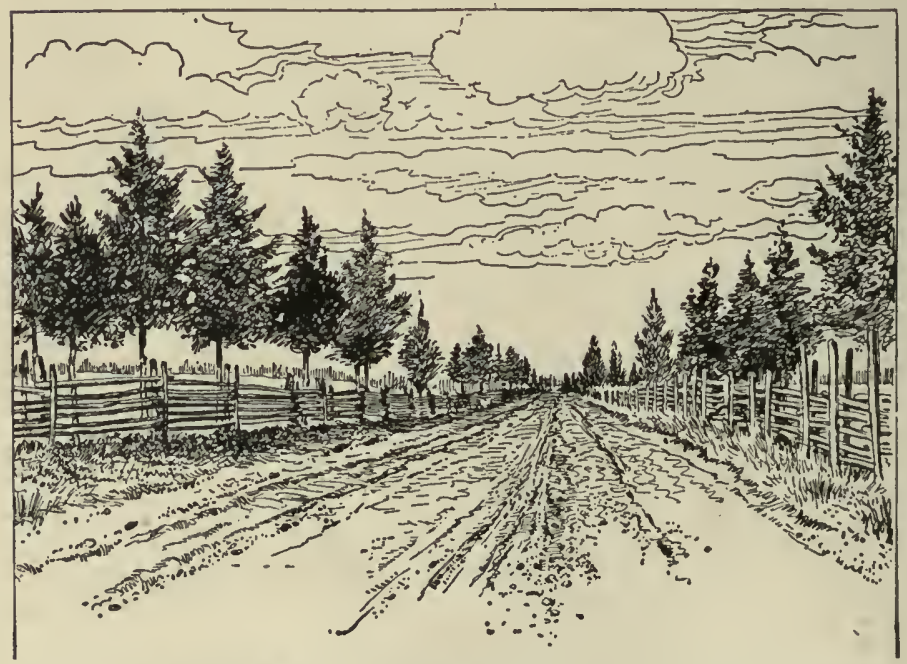

Fig. 5. Scattering of red cedar by birds. (U. S. Dept. Agrl.) 
II. WATER.

A. Seed with light, inflated pods, Sedges.

B. In large receptacles, Nelumbo (Water Chinquapin).

C. Mucilaginous seeds, Pepper Grass.

D. Currents of water in a mechanical way, Driftwood.

E. Plants floating on water because provided with air spaces, Lemna (Duckweed).

III. SNOW AND WIND CoMBINED.

Many weed seeds.

IV. Animals.

A. Fleshy, edible fruits and seeds, Nightshade, Cherry

B. Edible seeds not fleshy, Sunflower, Acorn.

C. Fruits with houks or barbs, Bidens (Beggar-ticks).

D. Seed or fruits with webs, Blue Grass.

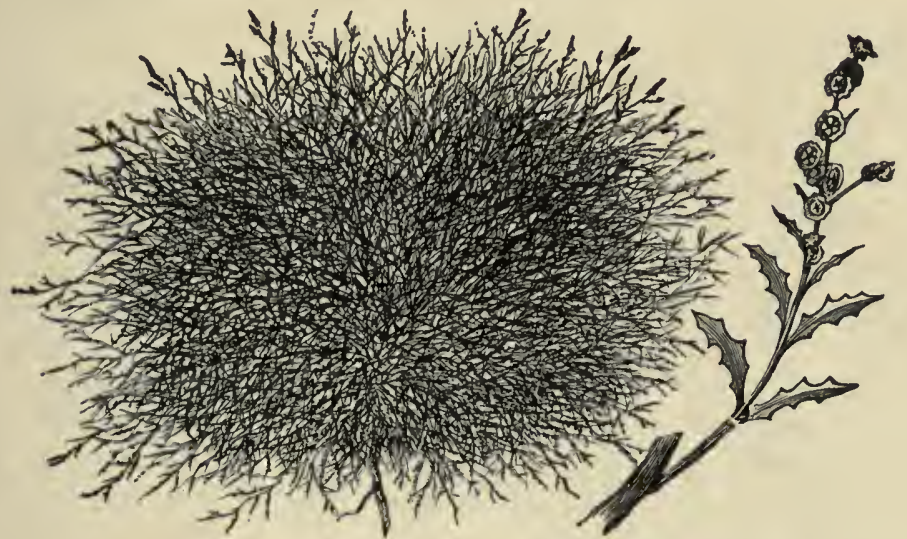

Fig. 6. A tumble weed, winged pigweed (Cycloloma atriplicifolium), scattered by its tumble habit. The Russian thistle and a kind of pigweed are scattered in the same way. (U. S. Dept. Agrl.)

V. Explosive Properties of Fruits and Seeds.

A. Contraction of seed vessel, as in Hura crepitans

B. Twisting of pod, Vetch.

C. Tension in pod, Impatiens (Jewel-weed).

D. Shooting of seeds, Oxalis.

E. Turgidity of fruit, Squirting Cucumber.

VI. Creeping Mechanisms and by the Seeds Burying Themselves.

A. Hygroscopic movements, Stipa.

B. Cleistogamous flowers, Violet.

VII. Man ás an Agent.

A. Impure seed, Clover Dodder. 
B. Common carriers, Russian Thistle.

C. Nursery stock and flowers, Canada Thistle.

D. Hay and wool, Buffalo Bur.

E. Plants grown for ornamental purposes, and as food plants, Ox-eye Daisy, Chicory.

Wind.-Many of our weeds are scattered by the wind. The squirrel-tail grass, which is permitted to grow in an unobstructed manner in pastures and on roadsides, is car-

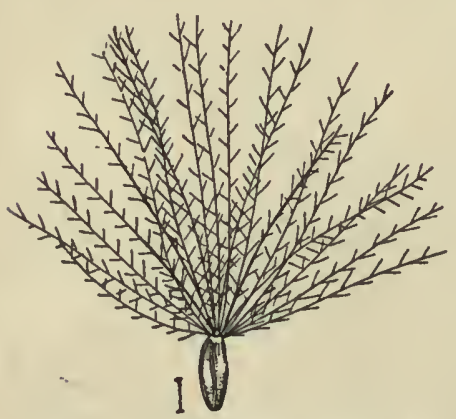

Fig. 7. Bull thistle "seed" scattered by the wind. ried to adjacent fields where it did not occur. Tumbleweed and Russian thistle have the rolling habit, and when growing along the roadsides or the railway they get into adjacent fields. In prairie countries the tumble habit is common for many weeds, as shown many years ago by Dr. Bessey. The seeds of milkweed with a light fluffy coma are carried for some distance. The "seeds" of dandelion with cylindrical body and a tuft of capillary bristles are carried for long distances from roadsides to fields and meadows. The bull thistle "seed" with hairy appendage is carried from the roadside to fields and pastures.

Wind and Snow.-Many seeds glide over the frozen snow and become deposited in the field. Greater ragweed is frequently carried in this way. So, too, are the foxtails. Prof. H. L. Bolley states that January 20, he found in the contents of a snow drift of 28 square feet, 2 seeds of pigeon grass, 5 of French weed, 2 of biennial wormwood. and $\mathrm{o}$ of barnyard grass. $\mathrm{He}$ also reports having distributed, on January $3 \mathrm{I}$, a peck of mixed seeds 30 rods distant from a drift of snow 4 rods long. In Io minutes this had caught a large number of millet, I9I 
wheat, 53 flax, 43 buckwheat, and 9I ragweed seeds. The wind was blowing at the rate of 20 miles per hour. There can be no question but that a drift holds a large number of weed seeds. Along our highways one may find, where the snow has drifted, the ragweed and thistle growing in large numbers.
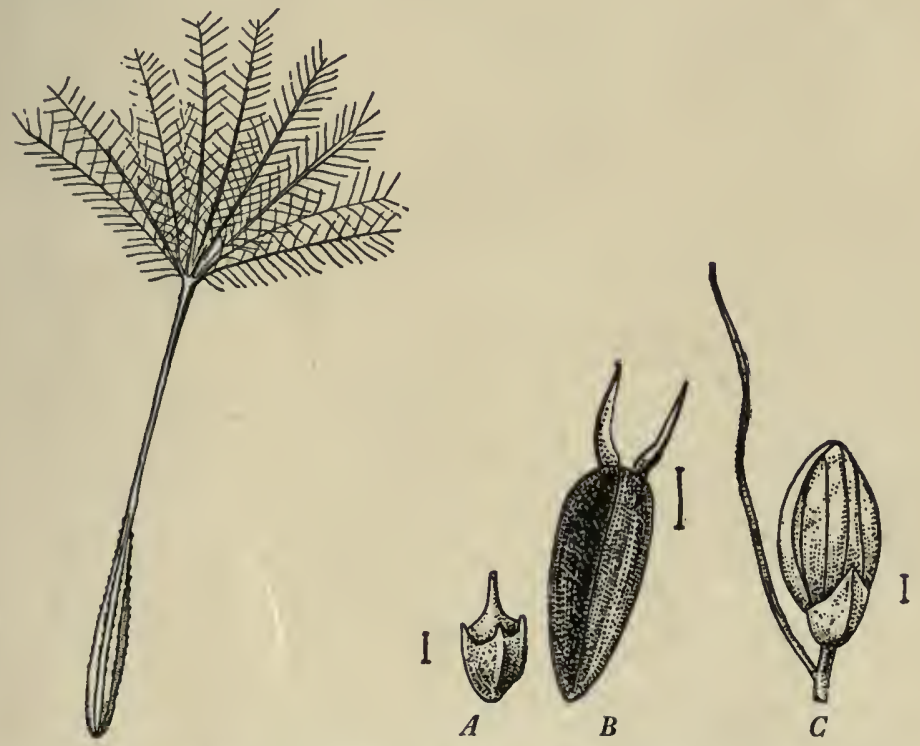

Fig. 8. The seed of vegetable oyster plant scattered by the wind.

Fig 9. Various "seeds" scattered by drifting snow. $A$, small ragweed; $B$, sunflower; $C$, foxtail.

Water.-A number of our very troublesome weeds are carried by the water. This is notably true for the "seeds" of docks. Three of the sepals or outer floral envelopes of the flower of the docks each bear an enlarged body called the tubercle, which is hollow. This body, combined with the calyx, enables it to float on the water. During our recent wet years, it has been noticed by 
farmers that these docks are unusually common on low ground, having been carried thither by water. Many seeds, like those of pepper grass, are mucilaginous. In

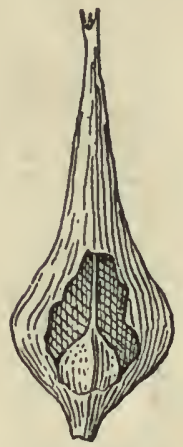

Fig. ro. The "seed" of a common sedge surrounded by an inflated sac, scattered by the water. (Beal.) walking through a patch of this weed with moist shoes, many seeds are caught and carried to new situations.

Wild oats and many other seeds may be found on land subject to overflow. These seeds are scattered in a mechanical way.

Animals.-Many of our weeds are scattered by animals, this being brought about either because the plants offer something for food, as in the ground-cherry, black nightshade, dandelion and thistle, or because the fruit is accidentally carried. Examples of the latter class are Spanish bayonet or bootjack, cocklebur or stick-seed, burdock, sandbur, and tick trefoil.

Explosive Properties.-We have but one weed the seeds of which have explosive properties. This is the yellow sorrel (Oxalis), which is common in some fields. The outer coat of the seed separates and the seed is forced out of the pod as though shot from it.

Creeping Mechanisms.-The needle-grass is important as a weed at times only, in gravelly pastures. The seed of this grass has a sharppointed callus and hairs above this point that project obliquely upwards. It has a long, twisted awn, and in this way the seed not only creeps

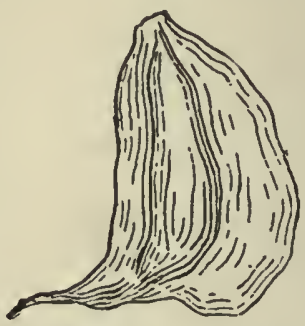

Fig. II The seedlike fruit of arrow-head, scattered by water. (Beal.) 
over the ground, but becomes buried. The wild oats also has a creeping arrangement.

Man as an Agent.-Nursery stock is responsible for the scattering of a number of weeds and weed seeds. The scattering of quack grass in this way had been reported to us. Canada thistle, ox-eye daisy, and other perennial weeds are known to have been carried and scattered by this means.

Wool.-Wool is often responsible for the introduction of a great many different weed seeds. Around woolen mills it is common to find Fuller's teasel, which is so commonly used in carding of wool. The western storksbill (Erodium cicutarium) no doubt owes its origin in this section to having been introduced with wool. There is constant danger when getting live stock from the western states that weeds of

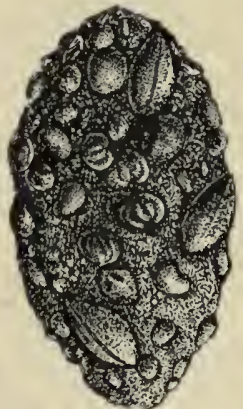

Fig. x2. Seeds scattered by birds. A cast from crow containing seeds of poison ivy, etc. (U. S. Dept. Agrl.) this character will be introduced. Some members of the borage family like Lappula floribunda have been scattered in this way.

Cultivation.- It is not uncommon to find that weeds are carried from one field to another by cultivators or plows. This is particularly true of quack grass and Johnson grass.

Impure Seed.-Many bad weeds are introduced with impure seed. We have during the past season received many specimens of weeds found in clover meadows. These weeds were undoubtedly introduced with clover seed.

In nearly all instances the farmers stated that they had not observed these weeds, before. Not all of the clover seeds sold by seed merchants contained these weed seeds, much of it being of good quality. 
As examples of presence in clover fields of weeds introduced with seed, a few selected areas observed July, 1908 . may be cited. Three areas ro feet square situated south-

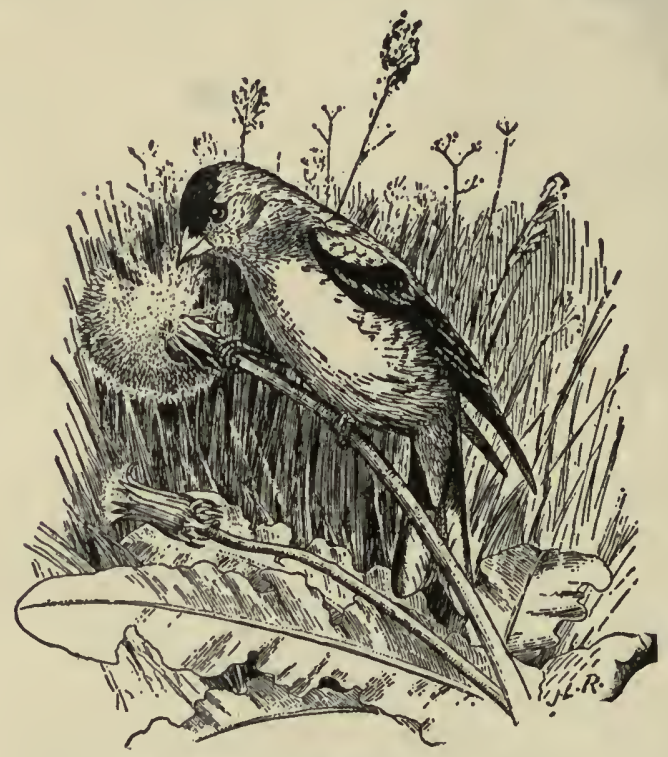

Fig. 13. Goldfinch eating the seed of dandelion. (U. S. Dept. Agrl.)
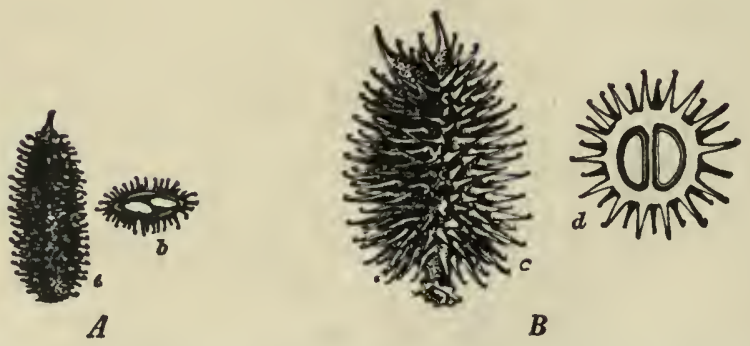

Fig. 14. $A, a, b$, pod of wild licorice. $B, c$, "seed" of cocklebur; $d$, section of carrot seed; scattered by animals. (Dewey, U. S. Dept. Agrl.) 
west of Ames averaged 53 vigorous specimens of ribgrass. Two areas 12 feet square upon a farm near Mar-
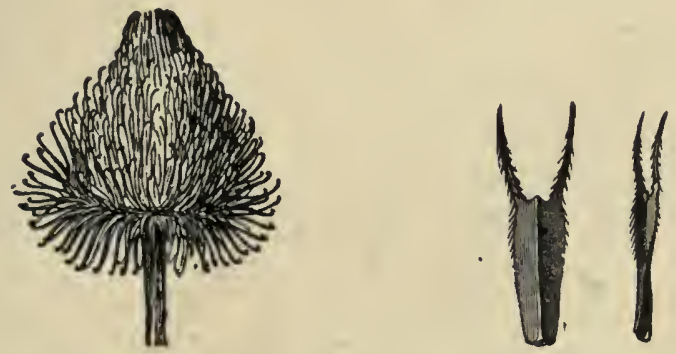

Fig. 15. Burdock head with many "seeds" scattered by animals. (Dewey, U. S. Dept. Agrl.)

Fig. I6. "Seed" of pitchforks, Spanish needle, scattered by animals. (U. S. Dept. Agrl.)

athon averaged six ribgrass and three wild carrot plants. In another piece of the same field not cut at Marathon,
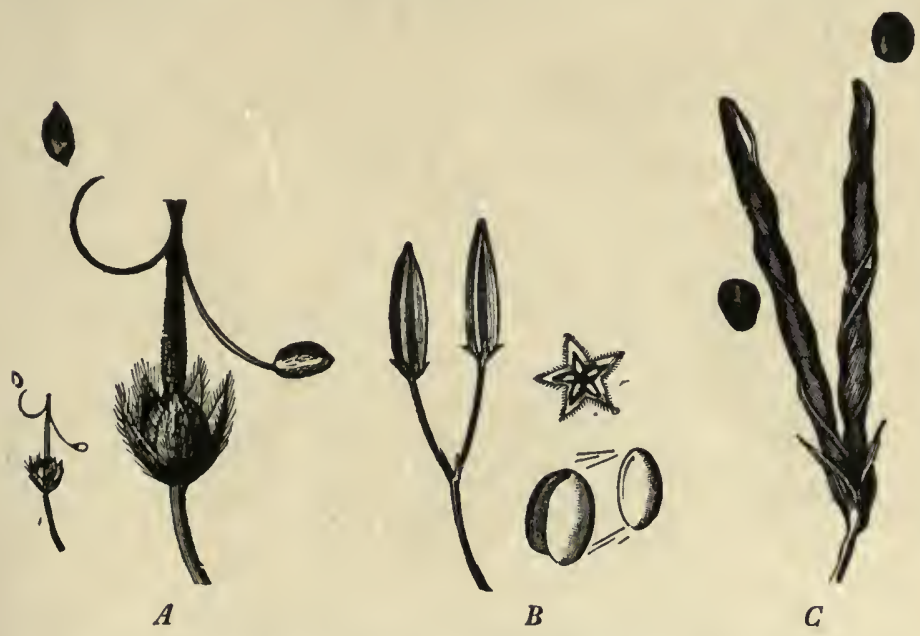

Fig. 17. Seeds scattered by explosive properties. $A$, geranium; $B$, wood sorrel; $C$, pod ot common vetch. (U. S. Dept. Agri.) 


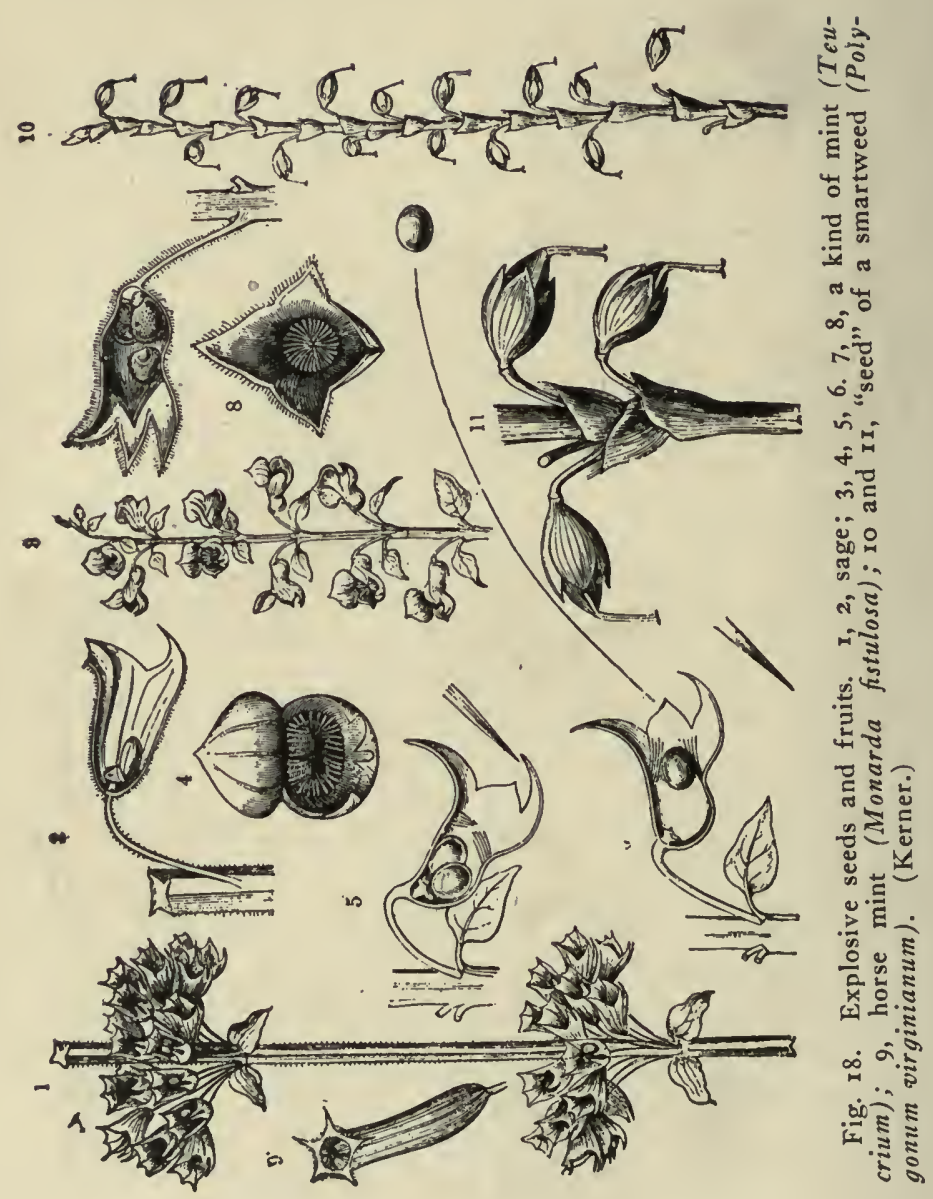


were found night-flowering catchfly, corn cockle, and bull thistle.

Grain Seed.-The wild oats is frequently scattered with oats, but there is little of this weed in Iowa except in a few counties in northern and northwestern parts. Mustard is also frequently scattered with oats. There is some danger of scattering quack grass seed with oats. Quack grass seed found maturing with oats will germinate. In one case 8 per cent. of the seed was capable of producing new plants. In an investigation of quack grass in northern Iowa and Minnesota it was found that it is nearly always scattered near the grain elevators. Straw is an
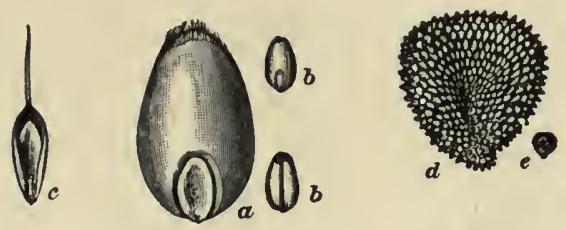

Fig. 19. Seeds distributed with wheat seed; $a$ and $b$, wheat; $d$ and $e$, cockle; $c$, common chess. (U. S. Dept. Agrl.)

important factor in scattering quack grass. A single farm has been responsible for scattering quack grass along the highway in every direction leading from the farm. The straw, with its seed of quack grass, fell along the roadside, and in a few years quack grass was observed along the highway. One farmer said the quack grass was introduced on his farm by using oat straw for covering his grapes. Many other similar cases, are on record. Cockle, cowherb and vetch are frequently scattered with wheat seed.

Garden Seed and Ornamental Plants.-Shoofly, which has been widely cultivated as an ornamental plant in this state, has scattered to the fields and has become a troublesome weed in grain fields. Mexican fireweed, 
cultivated as an ornamental plant, is becoming troublesome in many places. Butter-and-eggs was not only introduced as an ornamental plant and cultivated, but since has spread because sent out with horticultural plants. The bouncing bet, used as an ornamental plant,

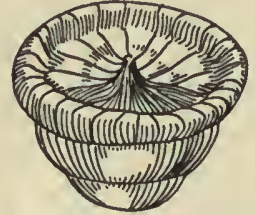

Fig. 20. Russian thistle, distributed with grain. (C. M. King.)

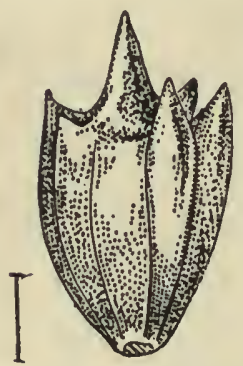

Fig. 2r. Kinghead or ragweed distributed with grain. (C. M. King.)

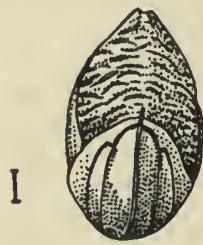

Fig. 22. Foxtail. (C. M. King.) has become troublesome in northwestern Iowa along the roadsides and in fields:. Other plants, as horseradish and ground-ivy, have become weeds in the same way.

Railways.-Some railways are using various kinds of screenings to sow along their right of way to cover the steep fills. A variety of weeds may be found here. Other weeds are scattered from passing cars. Russian thistle, buckhorn, ox-eye daisy, thistle, and other varieties of weeds may be found along the right-of-way. On a patch of ground of not more than two square rods in extent in a town in Central Iowa, in August. I908, the following weeds were observed by Miss Kellogg: Wild morning glory, hedge bindweed, prickly lettuce, sow thistle, pigweed, lamb's quarter, purslane, velvet weed, mallow, chickweed, shepherd's purse, sweet clover, burdock, curled dock, sheep sorrel, horseweed, pepper grass, wild-radish, black bindweed, water pepper, smartweed, milkweed, black mustard, ragweed, dog-fennel, mullein, creeping Charley, five-finger, squirrel-tail grass, sandbur, yellow foxtail, sedge, wire grass, and horse- 
tail. It is but fair to say that these weeds were mostly on soil that had been brought in by the railway company for the purpose of raising the grade of the road bed. Many of these weeds

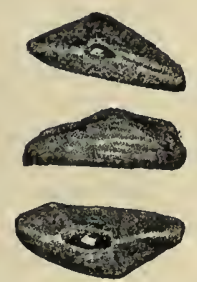

Fig. 23. Plantain. (C. M. King.)
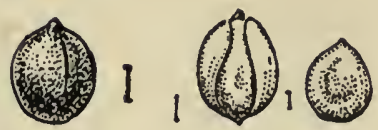

Fig. 24. Two kinds of smartweed. (C. M. King.)

have, however, in the course of five years, spread to the surrounding territory, and the problem of eradicating them has already become serious.

Highways.-Highways are an important factor in the distribution of weeds to adjacent fields. No matter how clean the fields are kept, if the seeds of plants like the

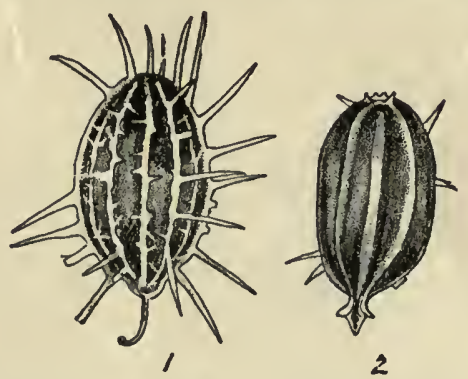

Fig. 25. Seeds found in red clover. 1 , 2, wild carrot. (C. M. King.)

cocklebur, Canada thistle, sweet clover, thistle, ragweed, and squirrel-tail grass are permitted to develop and mature along the highways they will naturally spread to 
the adjacent fields. Vehicles passing from a field infected with weeds, especially when the roads are moist, are sure to leave weed seeds along the roadsides. Then the driving of cattle, and the carrying of grain, all contribute to the weeds that are found along the roadsides, and to the scattering of the same.

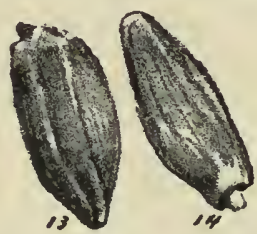

Fig. 26. 13, 14, Canada thistle. (C. M. King.)
The following is a partial list of weeds commonly found along the roadside: Poison ivy, horse-radish, horseweed, bull thistle, sweet clover, squirrel-tail grass, Russian thistle, tumbling mustard, cocklebur, mustard, large ragweed, small ragweed, foxtail, crab grass, partridge pea, wild blackberry, burdock, wild morning glory, milkweed, velvet leaf, and wild parsnip. 


\section{THE FARMER'S INTEREST IN GOOD SEED, AND HOW TO TEST SEED}

The farmer is especially interested in obtaining seed free from such noxious weeds as Canada thistle, quack grass and dodder. To avoid the introduction of such weeds, the seeds should be examined by the experiment station in the state in which the farmer is located or by the U. S. Dept. of Agriculture. It is customary in the seed laboratory to secure an average sample, thoroughly mixed, of the seed to be examined; then to weigh out 2 or 5 grams and separate out the impurities, such as weed seeds, dirt, chaff, etc. The remaining seed is then weighed and the amount of impurities determined. When a given quantity of weed seed is large this is weighed separately and the per cent of impurity obtained. A more accurate way is to use the table given below. This method is fairly accurate. We have for a number of years checked these results with those determined by weighing. If the weighing method is used, the analyst gives the total impurities and names those found.

The following table showing the number of seeds to the gram of various species of weed seeds was compiled by D. C. Snyder and Charlotte M. King in the Botanical Laboratory of the Iowa state college. To ascertain the number of seeds per pound in any given variety multiply the number per gram by 453.584 .

NUMBER OF SEEDS TO THE GRAM IN WRED SEEDS FOUND AS IMPURITIES IN CL.OVER SEED. PREPARED BY D. C. SNYDER AND C. M. KING

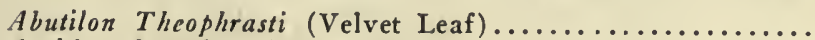
Acnida tuberculata (Water Hemp). 
Amarantus retroflexus (Tumbleweed) ............... 2,684 Arctium Lappa (Burdock) ....................... $\quad 320$

Brassica arvensis (Field Mustard).................. 496

Brassica nigra (Black Mustard)................ $\mathbf{1 , 2 8 0}$

Camelina sativa (False Flax) ..................... 900

Cassia Chamaecrista (Partridge Pea).................. Irg

Chenopodium album (Lamb's Quarter)............... 1,440

Cirsium arvense (Canada Thistle) ................. $\quad 880$

Cirsium discolor (Field Thistle)..................... $\quad \mathbf{1}_{74}$

Cirsium lanceolatum (Bull Thistle)................... $\quad 620$

Cirsium lanceolatum (dup.) ........................ 456

Cuscuta arqensis (Dodder)..................... $\quad$ 1,688

Cuscuta Epithymum (Clover Dodder)................ 3,840

Cyperus esculentus (Nut Grass) .................... 540

Datura Stramonium (Jimson Weed) $\ldots \ldots \ldots \ldots \ldots \ldots \ldots \ldots \ldots \ldots$

Digitaria sanguinalis (Crab Grass) ................ 3,640

Echinochloa crus-galli (Barnyard Grass)............. $\quad \mathbf{1 , 4 0 0}$

Euphorbia Preslii (Spurge) .....................

Hibiscus trionum (Bladder Kermia)................. 304

Ipomoea purpurea (Morning Glory)................. $4^{\mathrm{I}}$

Lepidium apetalum (Pepper Grass)................ 2,515

Medicago lupulina (Trefoil) ....................... . 692

Medicago sativa (Alfalfa)......................... 452

Melilotus alba (Sweet Clover)..................... 490

Monarda fistulosa (Horsemint).................... r,o8o

Nepeta Cataria (Catnip)....................... r,076

Oxybaphus nyctaginea (Oxybaphus)................. 404

Panicum capillare (Old Witch Grass) ............... 2,592

Phleum pratens (Timothy) ........................

Plantago aristata (Bracted Plantain) .................. $\quad 7_{760}$

Plantago lanceolata (Ribgrass)................... $\quad \mathbf{1 , 1 5 6}$

Plantago Rugelii (immature)..................... $\quad \mathbf{2 , 1 7 6}$

Plantago Rugelii (Rugel's plantain) ................ $\quad \mathbf{1 , 7 0 4}$

Poa pratensis (Blue Grass)...................... 17,050

Poa serotina (False Red Top).................... ro, 370

Polygonum Convolvulus (Bindweed)................. ${ }_{216}$

Polygonum Lapathifolium (Pale Smartweed).............. 640

Polygonum pennsylvanicum (Smartweed)............... 200

Polygonum Persicaria (Lady's Thumb) ................ 712

Potentilla monspeliensis (Five-finger) ................ $1 \mathrm{n}, 880$

Rumex Acetosella (Sheep Sorrel)................... 200

Rumex crispus (Curly Dock) ...................... ${ }_{728}$

Rumex obtusifolius (Dock)........................ 846

Saponaria Vaccaria (Cowherb) ..................... 228

Scrophularia marilandica (Simpson Weed).............. 6,690

Setaria glauca (Pigeon Grass), immature.............. 815

Setaria glauca ................................. $\quad 386$

Setaria italica (Millet) .......................... 544

Setaria viridis (Green Foxtail), immature.............. 2,140

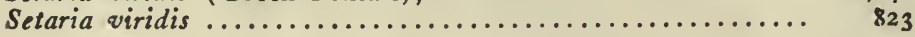


Silene stellata (Catchfly)......................... 900

Thalictrum purpurascens (Meadow-rue) ................. 496

Trifolinm hybridum (Alsike Clover) ................. $\quad \mathbf{1 , 6 0 4}$

Trifolium pratense (Red Clover).................... ${ }_{662}$

Trifolium repens (White Clover) ....................

Verbena stricta (Vervain) ......................

Verbena urticaefolia (Vervain) ..................... 2,408

Mr. J. R. Campbell has kindly worked out the following formula for determining the percentage of impurities in some of the different agricultural seeds. A table is herewith appended giving the number of seeds in one per cent of one teaspoonful or 5 grams of clover seed, and one per cent of one teaspoonful or 4 grams of timothy seed.

Analysis of Seed (Approximate).-In making an analysis of red clover or any other seed, the sample should be thoroughly mixed. If we have a sack of seed, a handful should be taken from the top, another from the middle, and another from the bottom of sack. Mix them in a pasteboard box, plate or anything handy; then take a pinch here and there until we have a slightly rounding teaspoonful. (Use common tin teaspoon.) Do not have it more than slightly rounding or the figures will be inaccurate.

Pour this out on a sheet of white paper, or glass, and with the aid of a toothpick, lead pencil or anything convenient, separate the good clover into one pile and the weed seed and dirt into another. Then with the help of the manual in identification, separate the different weed seeds and count them. Next find the percentages of each, using the table for this purpose. For example, suppose there are 120 seeds of crab grass and 16 seeds of buckhorn. The table says 182 seeds of crab grass are equal to I per cent. 'Therefore I2O seeds equal $12 \% 1 \mathrm{~s} 2$ of I per cent, or .659 per cent, and since 57 seeds of buckhorn equals I per cent, 16 seeds equal $16 / 57$ of I per cent, or .28 
per cent. The sum of both is .939 per cent, a little less than one per cent. The weight of the dirt will have to be guessed at, as it varies greatly with different kinds.

(The above method is for the use of those who have not the apparatus for an exact analysis. The results are, of course, only approximate, but are near enough for the purpose of the law.)

NUMBER OF SEEDS REQUIRED TO MAKE I PER CENT BY WEIGHT OF 5-GRAM SAMPLE (EQUAL TO ONE TEASPOONFUL OF SEED)

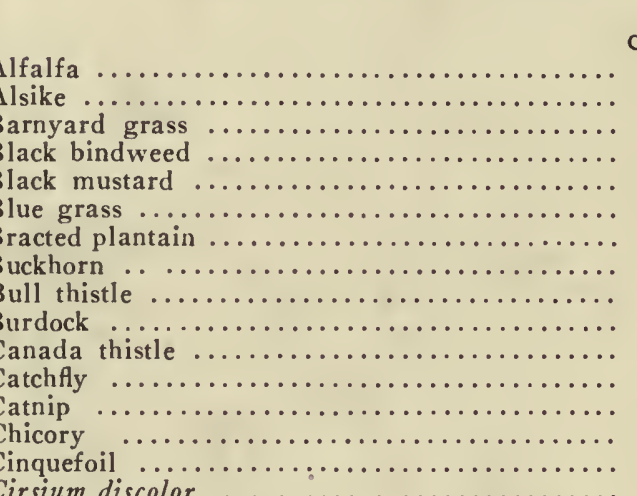

\begin{tabular}{|c|c|}
\hline & TIMOTHY \\
\hline 22 & I8 \\
\hline 80 & 64 \\
\hline 70 & 56 \\
\hline I I & 9 \\
\hline 64 & 51 \\
\hline 852 & 682 \\
\hline 38 & 30 \\
\hline 57 & 45 \\
\hline 23 & 19 \\
\hline 16 & 12 \\
\hline 44 & 36 \\
\hline 45 & 36 \\
\hline 53 & 43 \\
\hline 40 & 32 \\
\hline 594 & 475 \\
\hline 9 & $71 / 2$ \\
\hline I I & 9 \\
\hline 182 & 145 \\
\hline 36 & 28 \\
\hline 84 & 67 \\
\hline 192 & 156 \\
\hline 27 & 25 \\
\hline 210 & 168 \\
\hline 45 & 36 \\
\hline 518 & 414 \\
\hline 40 & 32 \\
\hline 54 & 43 \\
\hline $\begin{array}{r}7 \\
36\end{array}$ & $\begin{array}{r}5 \\
28\end{array}$ \\
\hline 72 & 57 \\
\hline 15 & 12 \\
\hline 24 & 20 \\
\hline 27 & 21 \\
\hline 2 & I $3-5$ \\
\hline
\end{tabular}




$\begin{array}{rc} & \text { TIMOTHY } \\ \text { CLOVERS } & \text { OT MILLFT } \\ 20 & \text { I6 } \\ 6 & 5 \\ \text { I26 } & \text { IOO } \\ 20 & 16 \\ \text { I34 } & \text { II8 } \\ 10 & 8 \\ 18 & 14 \\ 18 & 131 / 2 \\ 33 & 26 \\ 85 & 68 \\ 43 & 34 \\ 100 & 80 \\ 334 & 467 \\ 32 & 25 \\ 185 & 148 \\ 86 & 68 \\ 24 & 19 \\ 144 & 115 \\ 5 & 4 \\ 51 & 41 \\ 140 & 112 \\ 95 & 76 \\ 62 & 50 \\ 25 & 20 \\ 2 & 11 / 2 \\ 130 & 104 \\ 34 & 27 \\ & \end{array}$

Oxybaphus

Partridge pea

Pepper grass. . . . .

Pigweed

Polygonum pennsylvanicum

Quack grass

Ragweed

Red clover

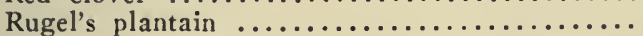

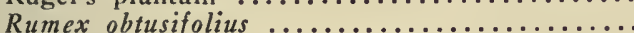

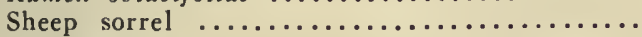

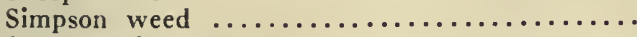

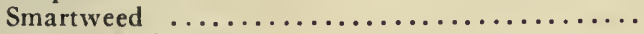

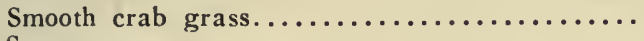

Spurge

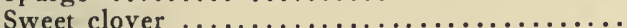

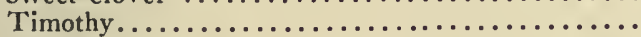

Velvet leaf

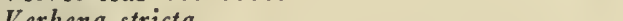

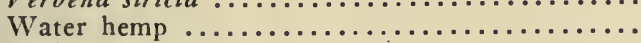

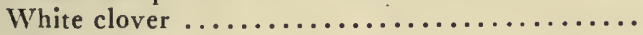

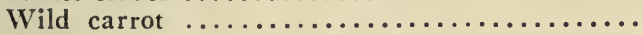

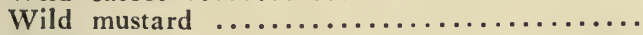

Wild oats $\ldots \ldots \ldots \ldots \ldots \ldots \ldots \ldots \ldots \ldots \ldots \ldots \ldots$

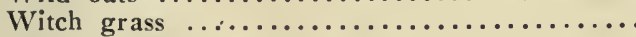

Yellow trefoil 
CHAPTER V.

\section{WEED IMPURITIES IN AGRICULTURAL SEEDS}

A large number of weed seeds of different kinds occur in various commercial seeds. These weed seeds vary, depending on the character of the crop and locality where the commercial seed was grown. The foreign material in the seed is largely accidental. For instance, the Iowagrown clover seed contains pigeon grass, foxtail, smartweed and other weed seeds found in the Iowa clover meadow. Clover seed grown in Missouri will have a great deal of bracted plantain, while eastern-grown seed has much buckhorn. Alfalfa seed grown in Utah is likely to have dodder, black medic, etc. Minnesota-grown wheat is sure to have corn cockle and vetch, while seed oats from the same state may have quack grass. Mustard is certain to occur in Iowa-grown oats. The fault is not always with the seed merchant. The farmer demands a cheap seed and in doing so is likely to buy seeds that contain many weed seeds. It is always better to buy the better quality of seed. I knew of a case where the farmer was selling his neighbor red clover seed at $\$ 9$ per bushel, when he could have bought good clover seed for a little more. Thirty-four per cent of the seed consisted of weed seeds and dirt. He was paying more for this seed than the best seed on the market was selling for.

The only way to buy seed is on a guaranty. It is an easy matter for the seed merchant to make a statement that his seed contains a given per cent of purity and is free from noxious weeds of a certain type. I believe most seed merchants are beginning to realize the importance of selling good seed. The matter of germination is so 
unreliable and the seed varies from year to year so much that very little that is definite can be given on this point.

Impurities of Red Clover Seed.-The kind of impurities found in red clover seed varies somewhat with the locality in which the clover is grown. In the United States the more common impurities reported are as follows: Rugel's plantain (Plantago Rugelii), green foxtail (Setaria viridis), lady's thumb (Polygonum Persicaria), lamb's quarter (Chenopodium album), ribgrass (Plantago lanceolata), curled dock (Rumex crispus), yellow foxtail (Setaria glauca), sorrel (Rumex Acetosella), large spotted spurge (Euphorbia nutans), bracted plantain (Plantago aristata), timothy (Phleum pratense), witch grass (Panicum capillare), smooth crab grass (Digitaria humifusa), crab grass (D. sanguinalis), tumble weed (Amarantus albus), alsike clover (Trifolium hybridum), night-flowering catchfly (Silene noctiflora), blue vervain (Verbena hastata), mayweed (Anthemis Cotula), ragweed (Ambrosia artemisiaefolia), barnyard grass (Echinochloa crus-galli), white clover (Trifolium repens), wild pepper grass (Lepidium virginicum), bull thistle (Cirsium lanceolatum), Canada thistle (Cirsium arvense), field dodder ( $C$ uscuta arvensis), wild carrot (Daucus Carota), black mustard (Brassica nigra), chicory (Chicorium Intybus), yellow trefoil (Medicago lupulina), five-finger (Potentilla monspeliensis), nimble will (Muhlenbergia mexicana and glomerata).

To illustrate the quality of seed in general use, the following statement of red clover seed, analyzed in Iowa, may be given:

One hundred and thirty samples of weighed red clover were examined for impurities and adulteration, the average per cent of impurities was 1.93 , the highest per cent was 33.2, only two samples consisted of pure seed. The following impurities were found in 255 samples of red clover seed in percentages, as follows: Timothy, 64.8; Canada thistle, 9.2 ; foxtail, 54.0 ; dodder, 4.0 ; bull thistle, 
6.o; sheep sorrel, 34.4; dock, 44.0, and others. Of the unweighed samples 63.8 per cent contained foxtail, 57.I per cent timothy, 5I per cent curled dock, 47.8 per cent green foxtail, 38.6 per cent rib plantain, buckhorn, or ribgrass; 28.5 per cent sheep sorrel, and II.9 per cent Canada thistle. Of the two hundred and fifty-five samples examined timothy was found in 162 , sand and dirt 138, yellow foxtail I35, green foxtail I28, curled dock IIo, sheep sorrel 86, bracted plantain 38,

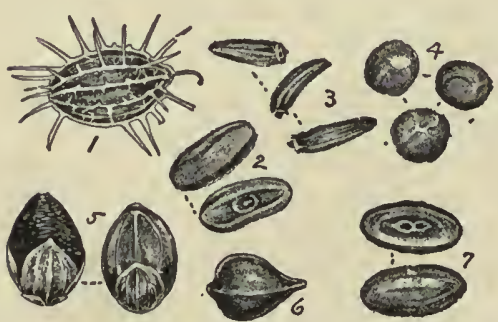

Fig. 27. Some impurities in red clover seed. I, wild carrot; 2 , buckhorn, two views; 3, Canada thistle; 4, clover dodder; 5, green foxtail, two views; 6, curled dock; 7, bracted plantain. (C. M. King.) evening cockle 22, Canada thistle 24 and dodder ro. It will be seen from the above partial list that many bad weed seeds are found in clover seed. We found, further, that clover seed in some instances showed a very low vitality. Only four of the samples showed a vitality of 99 per cent and over. There was a considerable number below 80 per cent and twenty-one samples above.

Impurities of White Clover Seed.-The more common impurities are sorrel mayweed, lamb's quarter, the plantains, dooryard knotgrass, night-blooming catchfly, fivefinger and chickweed.

The following illustration is given of samples examined in Iowa:

The impurities found in weighed samples of white clover were sheep sorrel, 44.4 per cent; plantain, 33.3; bracted plantain, II.I; lamb's quarter, II.I. Of these the sheep sorrel, dock and plantain are bad weeds. In the unweighed samples sheep sorrel occurred in 80 per 
cent of the samples. Slightly different results have been obtained in other localities. The kind of impurity will depend on locality.

Meadow Fescue: Common Impurities or.-Yarrow, Rugel's plantain, sedge, cinquefoil, chess or cheat,

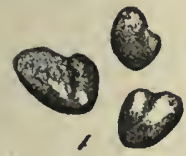

Fig. 28. I, three seeds of red clover; 2 , two seeds of sweet clover. (Hillman.) pepper grass, sorrel, brome grass, orchard grass, velvet grass (quack grass a possibility), English ryegrass.

Kentucky Blue Grass: Common Impurities of.- The impurities of Kentucky blue grass are practically the same as given for meadow fescue. although Kentucky blue grass may contain Canadian blue grass and English blue grass (meadow fescue).

Alsike: Common Impurities of.-Timothy, sheep sorrel, lamb's quarter, night-flowering catchfly, dooryard plantain, pigweed, pepper grass, red clover, wild clover, five-finger, crab grass, mayweed, curled dock, blue grass, hair grass. Alsike clover is not generally adulterated, but impurities were found as follows in Iowa: Sheep sorrel, 86. I per cent; plantain, 33.3 per cent; Canada thistle, 25 per cent; buckhorn or rib plantain, I I'. per cent.

- Alfalfa: Common Impurities of.-Green foxtail, yellow foxtail, red clover, bur clover, barnyard grass, yellow trefoil, crab grass, chicory, centaurea, alsike, sweet clover, wild rye, grindelia, Rugel's plantain. The chief impurities found in alfalfa are
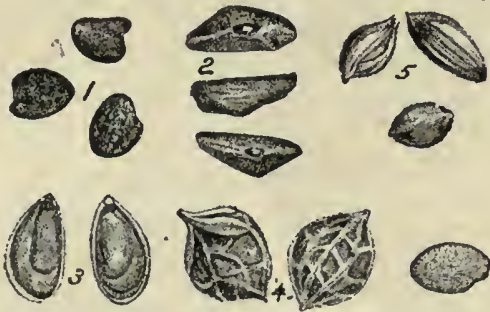

Fig. 29. Impurities in alsike. I, alsike clover; 2, Rugel's plantain; 3 , small pepper grass (Lepidium apetalum); 4, sheep sorrel (Rumex Acetosella), with covering; 5 , timothy, hulled and unhulled; 6, sweet clover. (C. M. King.) 
black medic, bur clover and sweet clover. The impurities found in samples examined in Iowa are alfalfa dodder, 4.I; knot weed, 4.I ; rib grass or buckhorn, 62.5; cockle, I2.5; Canada thistle, 8.3; sheep

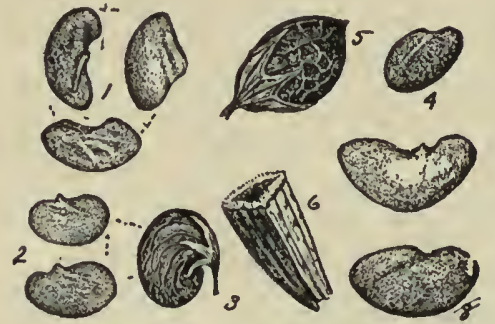

Fig. 3o. Some impurities in alfalfa. 1, alfalfa; 2 , seeds of yellow trefoil; 3 , pod of same; 4, seed of sweet clover; 5, pod of sweet clover; 6 , chicory; 7 , spotted clover; 8, bur clover. (C. M. King.) sorrel, 4.I ; plantain, 4.I; bracted plantain, 4.I; yellow foxtail, 33.I; curled dock, 8.3.

Impurities in Orchard Grass.-The more important impurities found in orchard grass are, fescue grass (Festuca pratensis), velvet grass (Holcus lanatus), especially in New Zealandgrown seed; English rye grass (Lolium percnne), blue pearl grass (Molinia caerulea), crested dog'stail (Cynosurus cristatus), dock (Rumex crispus), sheep sorrel (Rume.r Acctosella), pepper grass (Lepidium apctalum and $L$. virginicum).

The Vitality of Weed Seeds.-Some weed seeds show prolonged vitality; this is especially true of seeds that belong to the pulse and mallow families. The earliest recorded experiments on prolonged vitality of seeds are those of De Candolle. This writer
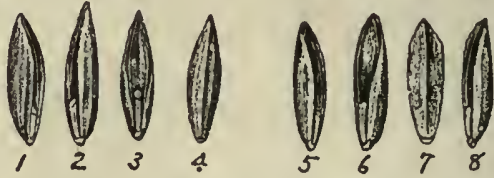

Fig. 31. $x-4$, seeds of Kentucky blue grass, the scales cover the seed; $5-8$, Canadian blue grass. Notice the difference in shape. (Hillman and King.) found that certain members of the mallow, pulse, and mint families had a prolonged vitality. Later Becquere! also made a study of the prolonged vitality of seeds, and he found of the 550 
species studied by him, the age of seeds varied from r25 to I35 years, and that a few of the old seeds germinated, notably those belonging to the pulse, water lily, and mallow families. In this connection the study made by Ewart on the Longevity of Seeds is of interest. Thus in some of the common Indian mallow or butter-print, 6 per cent of seed germinated after the lapse of 57 years, the common shoo-fly after 57 years, the
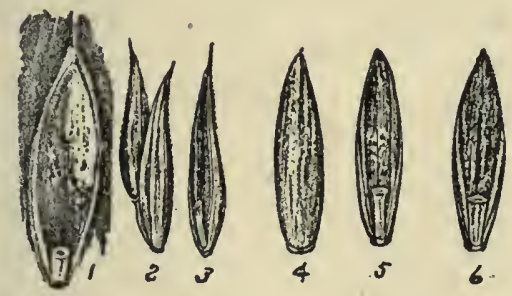

Fig. 32. Seeds of some grasses. I, quack grass; 2, 3, orchard grass; 4, 5 , meadow fescue; 6, English rye grass. (Hillman.) seed of white sweet clover showed germination after 77 years, and 52 per cent after 44 years, chicory after Io years. In this connection the experiments conducted by Dr. W. J. Beal are also of interest.

A number of years ago he made an interesting experiment on the prolonged vitality of the seeds of some common plants, testing for vitality at different periods of $5,10,15,20$, and 25 years. The seeds were placed in sand in bottles slanting downward so that water could not enter, and buried in the soil, 20 inches below the surface. The seeds were all grown the year they were buried. The * indicates that the seed germinated.

The following table indicates the vitality at these periods :

\section{NAME OF SEED}

Amarantus retroflexus ............ Ambrosia artemisiaefolia .........

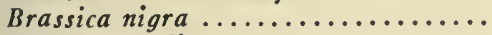
Bromus secalinus ............... Capsella bursa-pastoris .......... Erechthites iicracifolia ............. Euphorbia maculata.............

$\begin{array}{ccccc}5 \text { TH } & \text { IOTH } & \text { I5TH } & \text { 2OTH } & 25 T H \\ \text { YEAR } & \text { YEAR } & \text { YEAR } & \text { YEAR } & \text { YEAR } \\ * & * & * & * & * \\ 0 & 0 & 0 & 0 & 0 \\ 0 & * & * & * & * \\ 0 & 0 & 0 & 0 & 0 \\ * & 0 & * & * & * \\ 0 & 0 & 0 & 0 & 0 \\ 0 & 0 & 0 & 0 & 0\end{array}$




\section{NAME OF SEED}

Lepidium virginicum ...........

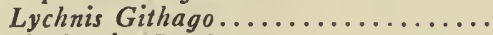

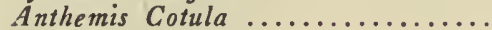

Malva rotundifolia ...............

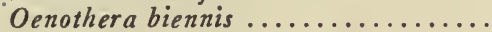

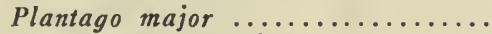

Polygonum Hydropiper............

Portulaca oleracea ................

Quercus rubra .................

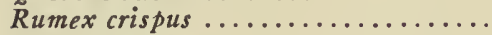

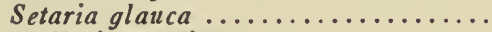

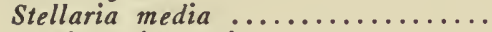

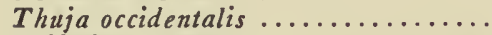

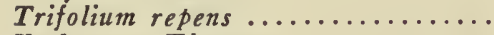

Verbascum Thapsus.............

$\begin{array}{ccccc}5 \mathrm{TH} & \text { IOTH } & \text { ISTH } & 2 \mathrm{OTH} & 25 \mathrm{TH} \\ \text { YEAR } & \text { YEAR } & \text { YEAR } & \text { YEAR } & \text { YEAR } \\ * & * & * & * & * \\ 0 & 0 & 0 & 0 & 0 \\ * & * & * & 0 & * \\ * & 0 & 0 & * & 0 \\ * & * & * & * & * \\ 0 & 0 & * & 0 & 0 \\ 0 & * & * & * & * \\ 0 & * & * & * & * \\ 0 & 0 & 0 & 0 & 0 \\ * & * & * & * & * \\ * & * & * & 0 & * \\ * & * & * & * & * \\ 0 & 0 & 0 & 0 & 0 \\ 0 & 0 & 0 & 0 & 0 \\ * & ? & * & * & *\end{array}$

Prof. L. R. Waldron has shown that in the case of some weeds there is delayed germination. He experimented with seven different kinds of weed seeds, as follows: Great ragweed or kinghead, wild oats, green foxtail, shepherd's purse, wild mustard, wild buckwheat and French weed.

In the fall of 1889 there were planted in a seed bed out of doors at depths of $1,2,3,4,5,7$, and ro inches the above seeds. During the same fall shepherd's purse produced a few plants at depths of $\mathrm{I}$ and 2 inches; French weed, 25 plants at $\mathrm{I}$ inch; wild mustard, many plants at I, 2 , and 3 inches; wild oats, several plants at 1,2 , and 3 inches.

During 1900 the seeds continued to germinate, and it was true of them that the small weed seed did not come up through 2 inches of soil; no seeds buried below 3 inches germinated except kinghead or great ragweed and wild oats, which came up through 5 inches of soil. The writer, Miss King and Mr. Fawcett have conducted some experiments on delayed germination of weed seeds.

It was found that the seeds of different species showed great differences in germination; in general the results 
of 1902 and 1903 indicated that stratification in sand and freezing were favorable to germination.

Weed $\quad$ Before stratification of germination

Milkweed ( $A$. syriaca) ................

Vestern ragweed ....................

Lamb's quarter......................

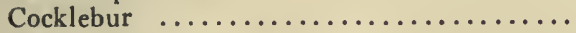

$\begin{array}{ll}0 & 12 \\ 0 & 18 \\ 0 & 88 \\ 0 & 25\end{array}$

Mr. H. S. Fawcett made a study of 52 species of weed seeds.

The samples were gathered after maturity in September, October and November of 1904. The seeds were threshed out, and placed in paper envelopes. Fifty seeds of each kind were placed in November in sand in boxes kept during the winter in the greenhouse under uniform conditions. Similar plantings were made each month until May. The sand in all these germination trays was kept moist.

In addition a large number of weed samples was placed out of doors for the purpose of subjecting them to freezing and thawing. The seeds were placed in sacks in a wooden box and covered with a thin layer of sand; the box was then deposited about one foot below the surface, where it remained till snring. The general effect of freezing and thawing was to increase the percentage of germination and lessen the dormant period, especially in case of seeds with hard coats; in all cases the dormant period of hard-coated seeds seems to be greater than that of thin-coated seeds. The following examples illustrate these differences:

The dormant period of common pigweed (Amarantus retroflexus) was nine and one-third days when kept in packages in a dry room, and six and one-third days after having wintered out of doors; its germination was increased from 40 to 50 per cent. In common pigeon grass the average dormant period was lessened from eleven to seven and one-quarter days; the percentage of germina- 
tion increased from $34^{1} / 2$ to 38 per cent. In wild rye the dormant period was lessened from nine to five days; the germination increased from 22 to 48 per cent.

It was found that the longest dormant period was found in those seeds which have the hardest and thickest seed-coats. Some of the ragweed seeds had a dormant period of 152 days, while some seeds of barnyard grass had a dormant period of 178 days.

The highest average percentage of germination was observed in common mustard, which was 100 per cent, and for the six tests, 90.3 per cent.

It has long been known that many seeds refuse to germinate until they have passed a period of rest. Nobbe and Hänlein made a study of the seeds of 31 species of weedy plants, continuing the experiment for I,I73 days. A number of these weeds showed germination after a lapse of I,I73 days; among them were Campanula persicifolia, silvery cinquefoil (Potentilla argentea), mouse-tail (Myosurus minimus), hoary plantain (Plantago media), and field penny-cress (Thlaspi arvense).

It would seem that freezing is decidedly favorable for the germination of many weed seeds. Of 65 species planted November, 1908 , four species failed to germinate; of 60 species planted in December, 48 failed; of 63 species planted in January, 44 failed; of the March planting of 62 species; 27 failed; of 59 species planted in April, 46 failed; of the seeds exposed to the weather, 64 species, 24 failed to germinate.

With the closest care and observation there was lack of constancy in the germination, resulting in marked irregularities not to be attributed to known causes, due possibly to inherent qualities.

Germinability of Weed Seeds After Having Been Kept in Compost and Manure.-There is a widespread impression that germinable weed seeds may be scattered with 
manure. This is true so far as seeds which get into manure not thoroughly composted are concerned.

Mr. E. I. Oswald made a series of experiments to ascertain the vitality of seeds when placed in manure under different conditions. Three kinds of manure were usedhorse manure, cow manure, and horse and cow manure mixed in equal parts. The manure was placed in separate piles, and seeds inclosed in gauze bags were placed in the manure and allowed to remain for varying periods of time, in some cases 60 days, in others six months. This lot contained 52 different kinds of seeds. After the required length of time, the seeds were planted in the greenhouse, and it was found that they had become thoroughly rotted and their vitality destroyed. In order to cover the conditions usually followed by dairymen and gardeners, where the manure remains but a short time, another set of experiments was started in the fall. The seeds remained in the pile only one month and were then planted as in the previous experiment. The results of the experiments entirely confirmed the previous ones, except in the cases of the seeds of ribgrass, horse nettle, common plantain, large ragweed, bitter dock, and mallow, which were still firm.

Early in the summer of 1908 we placed 31 different seeds of weeds and seeds of a few cultivated plants in gauze bags and left them in horse manure for five weeks. The seeds were placed in this manure on May Io and were removed June 19. The seeds were then germinated in the greenhouse. Only a small percentage of the following weed seeds were capable of germination.

We also conducted some experiments in feeding various weed seeds to animals, among them sour dock, quack grass, and sunflower; very little seed was capable of germination after it had passed the digestive tract of the animals. It is well-known, however, that hard-coated seeds do pass the digestive tract uninjured. Numerous 
cases of animal dissemination of seeds such as mesquit, acacia, and honey locust, are on record. In some cases even the seeds of corn, oats, millet, and foxtail have been found capable of germination after they have passed the digestive tract of animals. However, there is little danger from these in manure.

\section{The Results of a Test of Germinability of Seeds which Had Been Deposited in Manure for Five Weeks.}

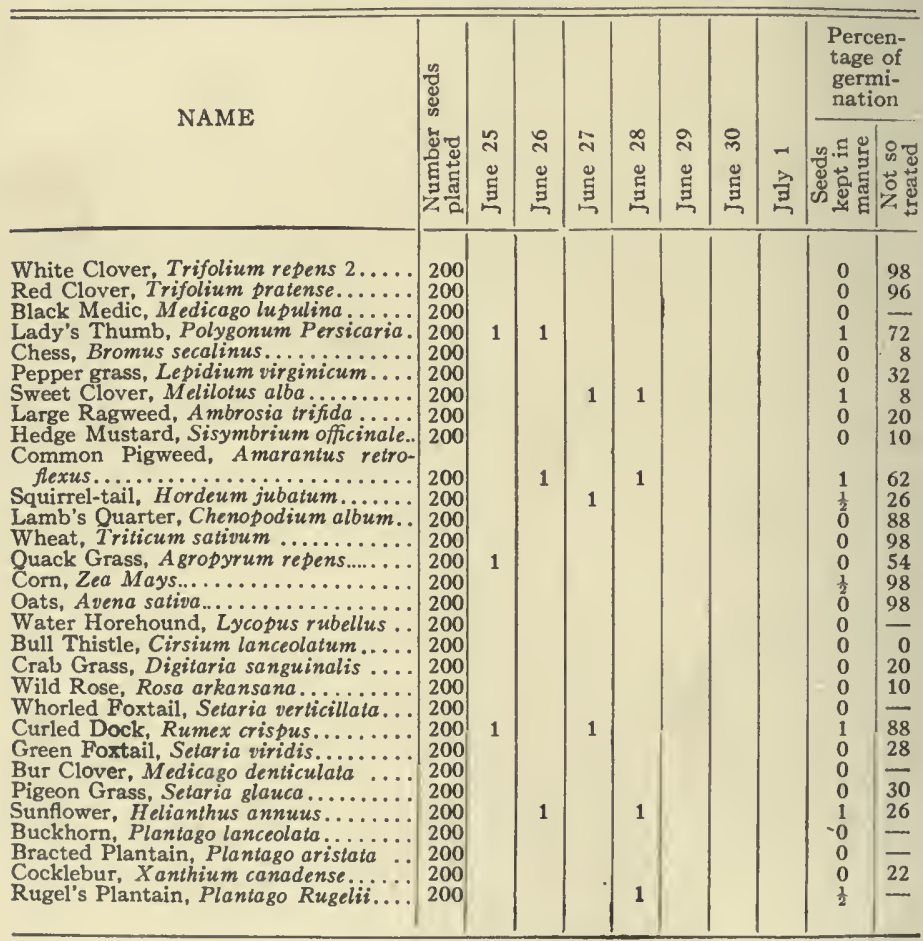




\section{SOME WEED LAWS AND SEED-CONTROL LAWS}

In connection with weed control the following laws are published herewith: The Iowa Weed Law, the Iowa Seed Law, which has formed the basis for seed laws of several states, and the seed law proposed for general adoption, prepared by a committee of the American Seed Trade Association and the American Association of Official Seed Analysts.

\section{THE IOWA WEED LAW}

Section r. Land Owners or Tenants to Destroy Weeds; When.It shall be the duty of every person, firm or corporation owning, occupying or controlling lands, town and city lots, land used as right of way, depot grounds or for other purposes to cut, burn or otherwise entirely destroy all weeds of the kinds mentioned in section two (2) hereof at such times in each year and in such manner as shall prevent the said weeds from blooming or coming to maturity.

SEc. 2. Noxious WeEDs. - The following weeds are hereby declared to be noxious weeds, namely: Quack grass (Agropyron repens), Canada thistle (Cirsium arvense), cocklebur (Xanthium canadense), wild mustard (Brassica arvensis), sour or curled dock (Rumex crispus), smooth dock (Rumex altissimus), buckhorn or ribbed plantain (Plantago lanceolata), and wild parsnip (Pastinaca sativa), horse nettle (Solanum carolinense), velvet weed or button weed (Abutilon Theophrasti) and burdock (Arctium lappa).

Sec. 3. Destructicn on Highways; Neglect or Refusal to DeSTROY.-It shall be the duty of the township trustees or other officers responsible for the care of public highways in each township or county in this state to destroy or cause to be destroyed all noxious weeds mentioned in section two (2) hereof or unnecessary brush on the highways in such a manner as to effectually prevent the production of their seeds or their propagation in any other manner, to warn out labor or to employ labor for this purpose in the same manner as for repairs to the highways, and for neglect or failure to perform this work they shall be subjected to the penalties in this act. If any occupant of lands adjacent to the public highways neglect or refuse to destroy the noxious weeds upon his land, or shall fail to prevent the said noxious weeds from blooming or coming to maturity, when such weeds are likely to be the means of infesting the public highway, or upon complaint of any landowner to the township trustees that his lands have been or are 
likely to be infested by weeds from the lands of another, including railway right of way, the trustees shall make investigation of such condition or complaint, and if the same appe. to be well founded, they shall make an order fixing the time within which the weeds shall be prevented from maturing seed, and an order that within one year such noxious weeds shall be permanently destroyed, and prescribing the manner of their destruction and shall forthwith give notice to the occupant of the lands where the noxious weeds exist, and if he shall neglect to obey such order within the time so ordered the trustees may cause such noxious weeds to be prevented from maturing seeds or may cause such noxious weeds to be permanently destroyed, and the cost of the work shall be recovered from the owner by a special tax, to be certified by the township clerk in the same manner as other road tax not paid.

Sec. 4. Road Funds May Be Expended.-The destruction of noxious weeds in the public highway and other public places is hereby made a part of the road work of the township trustees and the county supervisors, and they shall have authority to expend road funds for the destruction of weeds.

SEC. 5. PROPERTY TAX.-The law, as it appears in section fifteen hundred and twenty-eight (1528) of the supplement to the code, 1907, is hereby amended as follows, namely: By inserting after the comma in the eighth line thereof the following words: "and for the destruction of noxious weeds in public highways and other public places," and by striking out the word "four" in the tenth line of said section and inserting the word "six" in lieu thereof.

SEC. 6. School of InSTRUCTION.-Between November and the succeeding April of each year the county supervisors shall call a meeting of the township trustees and the road supervisors of the county to consider the best methəds of road work anc weed destruction, and in the public interest may secure services of experts to give instruction in road building and weed destruction. For such attendance the same compensation shall be allowed to the trustees and road supervisors and the county supervisors as is allowed by law for other services, to be paid as other expenses. The expenses of experts herein provided for may be paid from the county road fund

Sec. 7. Cutting of WEEDS of Highways.--It shall be the duty of township trustees and other officers directly responsible for the care of public highways to cause to be cut near the surface all weeds on the public highways in their respective districts at such times and in such manner as to prevent seeds from maturing.

SEC. 8. PENALTY. - Any person, firm or corporation violating any of the provisions of this act, or any township trustees, inspector or other officer who neglects or fails to perform the duties incumbent on him under the provisions of this act, shall be guilty of a misdemeanor, and shall be punished by a fine not exceeding one hundred dollars ( $\$ 100.00)$.

IOWA SEED LAW

SECTION r. Every lot in bulk, barrel, bag, pail, parcel or package of concentrated commercial feeding stuffs as defined in section three (3) of 
this act; and every parcel, package or lot of agricultural seeds as defined in section nine (9) of this act, and containing one pound or more, offered or exposed for sale in the state of Iowa, for use within this state, shall have affixed thereto, in a conspicuous place on the outside thereof, distinctly printed in the English language, in legible type not smaller than eight point heavy gothic caps, or plainly written, a statement certifying:

In the case of agricultural seeds:

First. The name of the seed.

Second. Full name and address of the seedsman, importer, dealer or agent.

Third. A statement of the purity of the seed contained, specifying the kind and percentage of the impurities as defined in sections eleven (II) and twelve (I2) hereof, provided that said seeds are below the standards fixed in this act.

Fourth. Locality where said seed was grown, when known.

SEC. 6. The state food and dairy commissioner shall cause to be made analyses of all agricultural seeds sold or offered for sale in this state. Said state food and dairy commissioner is hereby authorized, in person or by deputy, to take for analysis a sample from any lot or package of agricultural seeds, a sample not exceeding four ounces in weight; but said sample shall be drawn or taken in the presence of the party or parties in interest, or their representative, and shall be taken from a parcel, lot or number of parcels which shall not be less than five per cent of the whole lot inspected and shall be thoroughly mixed and divided into two samples and placed in glass or metal vessels carefully sealed and a label placed on each, stating the name or brand of the agricultural seeds or material sampled, the name of the party from whose stock the sample is drawn, and the date and place of taking such sample, and said label shall be signed by the said state food and dairy commissioner, or his authorized agent; or said sample may be taken in the presence of two disinterested witnesses; one of said duplicate samples shall be left on the premises of the party whose stock was sampled and the other retained by the state food and dairy commissioner, for analysis and comparison with the certified statements required by sections one ( 1 ) and four (4) of this act. The result of the analysis of the sample, together with additional information, shall be published from time to time in bulletins issued by the state food and dairy commissioner upon approval of the executive council.

SEC. 7. Any person purchasing any agricultural seeds in this state for his own use, may submit fair samples of said seeds to the state food and dairy commissioner, who, upon receipt of an analysis fee of fifty cents ( $5 \circ c$.) for each sample of agricultural seeds, shall cause an analysis of the same to be made.

SEC. 8. No person shall sell in ground form, wheat or rye screenings containing cockle or other poisonous or deleterious substances.

SEC.9. The term, agricultural seeds, as used in this act, shall include the seeds of the red clover, white clover, alsike clover, alfalfa, Kentucky blue grass, timothy, brome grass, orchard grass, red top, meadow fescue, oat grass, rye grass and other grasses and forage plants, flax, rape and cereals. 
SEc. ro. No person shall sell, offer, or expose for sale, or distribution in this state, for the purpose of seeding, any of the agricultural seeds as defined in section nine (9) of this act, unless the said seeds are free from the seeds of the following weeds: Wild mustard or charlock (Brassica sinapistrur:), quack grass (Agropyron repens), Canada thistle (Cnicus arvensis), wild oats (Avena fatua), clover and alfalfa dodder (Cuscuta epithymum), field dodder (Cuscuta arvensis), and corn cockle (Lychnis githago).

SEC. II. The seeds of the following weeds shall be considered as impurities in the agricultural seeds as defined in section nine (9) of this act, sold, offered, or exposed for sale, within the state for the purpose of seeding: White cockle (Lychnis vespertina), night-flowering catchfly (Silene noctiflora), 'urled dock (Rumex crispus), smooth dock (Rumex altissimus), sheep sorrel (Rumex acetosella), yellow trefoil (Medicago lupulina), bur clover (Medicago denticul), sweet clover (Melilotus alba and $M$. officinalis) black mustard (Brassica nigra), plantain buckhorn (Plantago lanceolata), bracted plantain (Plantago aristata), bindweed (Convolvulus sepium), smooth crab grass (Panicum glabrum), common chickweed (Stellaria media). When such impurities or any of them are present in quantity exceeding a total of 2 per cent of the weight of said agricultural seeds, the approximate percentage of each shall be plainly indicated in statement specified in sec. one ( $I$ ) of this act.

SEC. r2. Sand, dirt, chaff and foreign substances and seeds other than those specified in sections thirteen (13) and fourteen (14), or broken seed and seed not capable of germinating, shall be considered impurities when present in agricultural seeds sold, offered, or exposed for sale, in this state, for the purpose of seeding, and when such impurities, or any of them, are present in quantity exceeding the standards of purity and viability authorized in section sixteen (16) of this act, the name and approximate percentage of each shall be plainly indicated in the statement specified in section one ( $I$ ) of this act.

SEC. I3. For the purposes of this act, seeds shall be deemed to be mixed or adulterated:

First. When orchard grass (Dactylis glomerata) seed contains ro per cent or more by weight of meadow fescue (Festuca elatior pratensis) seed, or Italian rye grass (Lolium italicum) seed, or English rye grass (Lolium perenne) seed.

Second. When blue grass or Kentucky blue grass (Poa pratensis) seed contains 5 per cent or more by weight cf Canadian blue grass ( $P$ oa compressa) seed, red top chaff, red top (Agrostis alba) seed, or any other seed or foreign substance.

Third. When red clover (Trifolinm pratense), mammoth red clover (Trifolium pratense var.), or alfalfa (Medicago sativa), contains 5 per cent or more by weight of yellow trefoil (Medicago lupulina), or sweet clover (Melilotus alba and M. officinalis) seed or bur clover (Medicago denticulata) seed.

Fourth. When rape (Brassica rapa) contains 5 per cent or more of common mustard (Brassica sinapistrum) or black mustard (B. nigra).

SEC. 14. For the purposes of this act, seed shall be deemed to be misbranded: 
First. When meadow fescue (Festuca elatior pratensis), English rye grass (Lolium perenne) or Italian rye grass (Lolium italicum) is labeled or sold under name of orchard grass (Dactylis glomerata) seed.

Second. When Canadian blue grass (Poa compressa) seed, red top (Agrostis alba) seed, or any other se:d not blue grass seed, is sold under the name of Kentucky blue grass or blue grass (Poa pratensis) seed.

Third. When yellow trefoil (Medicago lupulina), bur clover (Medicago denticulata) or sweet clover (Melilotus alba) is sold under the name of clover, June clover, red clover ( $T$ rifolium pratense), medium red clover, small red clover, mammoth red clover, sapling clover, peaine clover ( $T$. pratense var.), or alfalfa (Medicago sativa) seed.

Fourth. When the seeds are not true to name under which they are sold.

SEC. 15 . The provisions concerning agricultural seeds contained in this act shall not apply to:

First. Any person or persons growing or selling seeds for food purposes only, or having such seeds in possession for sale for such purposes.

Second. Any person selling seeds direct to merchants to be cleaned or graded before being offered for sale for the purpose of seeding. This shall not, however, exeinpt the seller from the restrictions of section ten (ro) of this act.

Third. Seed that is held in storage for the purpose of being recleaned, and which has not been offered, exposed or held in possession of or for sale for the purpose of seeding.

Fourth. Seed marked "not absolutely clean," and held or sold for export outside the state only.

Fifth. The sale of seed that is grown, sold and delivered by any farmer on his own premises for seeding by the purchaser himself, unless the purchaser of said seeds obtains from the seller at the time of the sale thereof a certificate that the said seed is supplied to the purchaser subject to the provisions of this act.

Sixth. Mixtures of seeds for lawn or pasture purposes. This shall not, however, exempt the seller of such mixtures of seeds from the restrictions of sections ten (ro) and eleven (II) of this act.

SEC. 16. The following standards of purity (meaning freedom from weed seeds or other seeds) and viability are hereby fixed:

\section{STANDARD OF PURITY AND VIABILITY OF AGRICUL- TURAL SEEDS}

\begin{tabular}{|c|c|c|}
\hline Name of Seed & purity & minable seeds \\
\hline $\begin{array}{l}\text { Alfalta }(\text { Medicago sativa }) \ldots \ldots \ldots \ldots \\
\text { Barley } \quad \ldots \ldots \ldots \ldots \ldots\end{array}$ & $\begin{array}{l}96 \\
98\end{array}$ & $\begin{array}{l}80 \\
90\end{array}$ \\
\hline Blue grass, Canadian (Poa compressa).. & 90 & 45 \\
\hline Blue grass, Kentucky (Poa pratensis).. & 80 & 45 \\
\hline Brome, awnless (Bromus inermis)..... & 90 & 75 \\
\hline Clover, alsike (Trifolium hybridum). $\therefore$ & 90 & 75 \\
\hline Buckwheat $\ldots \ldots \ldots \ldots \ldots \ldots \ldots \ldots \ldots$ & 96 & 90 \\
\hline Clover, crimson (Trifolium incarnatum) & 98 & 85 \\
\hline Clover, red (Trif & 92 & 80 \\
\hline
\end{tabular}




\section{Name of Seed}

Clover, white (Trifolium repens)......

Corn, field (Zea mays)...............

Corn, sweet..$\ldots \ldots \ldots \ldots \ldots \ldots \ldots$.

Fescue, meadow (Festuca pratensis)....

Flax (Linum usitatissimum)..........

Millet, common (Setaria italica).......

Millet, hog (Panicum miliaceum)......

Millet, pearl (Pennisetum typhoideum).

Oats (Avena sativa)................

Oat grass, tall (Arrhenatherum avena-

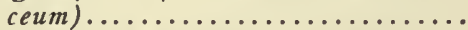

Orchard grass (Dactylis slomerata)...

Rape (Brassica rapa)................

Red Top (Agrostis alba).............

Rye (Secale cereale)...............

Rye grass, perennial (Lolium perenne).

Rye grass, Italian (Lolium italicum)....

Sorghum (Andropogon sorghum)......

Sorghum, for fodder ...............

Timothy (Phleum pratense)...........

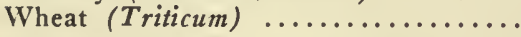

Per cent of Per cent of gerpurity minable seeds

$\begin{array}{ll}90 & 75 \\ 99 & 94 \\ 99 & 75 \\ 95 & 85 \\ 96 & 89 \\ 90 & 85 \\ 90 & 85 \\ 99 & 65 \\ 98 & 90 \\ & \\ 72 & 70 \\ 70 & 70 \\ 99 & 90 \\ 90 & 70 \\ 98 & 90 \\ 96 & 90 \\ 95 & 80 \\ 96 & 80 \\ 90 & 60 \\ 96 & 85 \\ 98 & 90\end{array}$

SEc. 17 . It is hereby made the duty of the state food and dairy commissioner to enforce the provisions of this act. The inspectors, assistants and chemists appointed by the state food and dairy commissioner shall perform the same duties and have the same authority under this act as are prescribed by chapter one hundred and sixty-six (166), laws of the thirty-first general assembly, and the said state food and dairy commissioner may appoint, with the approval of the executive council, such analysts and chemists as may be necessary to carry out the provisions of this act.

SEc. I8. Whoever sells, offers or exposes for sale any of the seeds specified in sections thirteen ( $x_{3}$ ) and fourteen ( $x_{4}$ ) of this act which are mixed, adulterated or misbranded, or any agricultural seeds which do not comply with sections ten (xo), eleven (II) and twelve (I2) of this act, or who shall counterfeit or use a counterfeit of any of the tags prescribed by this act; or who shall prevent or attempt to prevent any inspector in the discharge of his duty from collecting samples or who shall violate any of the provisions of this act shall be guilty of a misdemeanor, and upon conviction, shall be fined not more than one hundred dollars $(\$ 1 \infty)$ and costs of prosecution; provided, that no one shall be convicted for violation of the provisions of section ten (ro) of this act if he is able to show that the weed seeds named in section ten (10) are present in quantities not more than one in ten thousand, and that due diligence has been used to find and remove said seeds.

SEC. 19. There is hereby appropriated, for the purpose of enforcing the provisions of this act, a sum not exceeding three thousand dollars $(\$ 3, \infty 0)$ annually. Such expense shall be paid by warrant of the state 
auditor upon bills filed by the state food and dairy commissioner with the executive council and approved by them. All fees collected under the provisions of this act shall be paid into the state treasury.

The above law has been enacted nearly in the above form in several states as Washington and Wisconsin. There are also laws in Kentucky, Maine, North Dakota, Michigan, New York, and Canada. The laws of Kentucky, Maine and Canada have been in operation longer than in Iowa. The Maine law is based on a guaranty. The Iowa law fixes standards of vitality and purity. It is well known that vitality varies from year to year. This cannot well be fixed by statute. At a recent meeting of the American Association of Official Seed Analysts in conference with a committee of the American Seed Trade Association, and the Wholesale Seedsmen's League and Wholesale Grass Seed Dealers' Association, agreement was reached to recommend uniform state seed legislation and require that seeds shall be sold under a guaranty rather than the Iowa law, which fixes the purity and vitality. Each state will naturally exclude certain weeds. In Iowa the Canada thistle, dodder and quack grass should be excluded. 


\section{CHAPTER VII.}

\section{WEEDS OF SPECIAL CROPS}

Weeds of Meadows and Pastures.-The weeds of meadows differ in various places according as they are affected by the soil, climate or latitude. In well-kept pastures and meadows weeds are seldom troublesome, but in those not well kept weeds are certain to appear, although a pasture without a weed is not possible. It has been said that when land is well farmed weeds cannot survive. In alternate husbandry, weeds ought to succumb rapidly, but in pastures and meadows it is more difficult to remove them, for weeds will grow only where there is room, where they can obtain plenty of sunshine and light, and the more room they have the more vigorously they will grow. Bailey says: "Ground may be covered with a given plant, and yet a species of wholly different character and habits may thrive along with it. If weeds, then, are to be kept out of grounds, the land must not only be occupied with some crop, but with some crop that will not allow the weed to grow with it." Now, the first condition of weediness of meadow or pasture is the destruction of the turf. This is done by overstocking, or is the effect of cold or drouth. The native prairie would afford valuable pasture were it not for overstocking. This sod, at one time, contained a large number of species of different grasses as rich in nutrient qualities and producing as bountiful crops as any pastures east of the Mississippi. These were naturally a great source of revenue, but during the last decade this has changed. Jared G. Smith says: "It was a magnificent legacy to the rancher and the farmer. To the one it promised food for a million cattle; to the other it proved the golden possibilities of a soil 
that would bring forth bountiful harvests." But no time should be lost. Prof. Toumey says, in regard to conditions in Arizona: "In the early days of our great West almost the only method of travel from the Mississippi Valley to our western coast and intervening points was by caravan. Wagons drawn by horses and cattle were several months in making the journey. During this time they subsisted almost entirely upon the natural forage afforded by the country traversed. For the most part this consisted of perennial grasses, which at that time were everywhere abundant. The whole of the West was then a great open pasture, unstocked save for the herds of buffalo, deer and antelope. Many regions which were then covered with a luxuriant growth of grasses are now entirely destitute of vegetation, if we exclude a few straggling, stunted bushes and the yearly crop of annuals which follow the summer rains. As a more specific case, the rancher who drove the first herd into Tonto basin, in central Arizona, found a well-pastured valley, everywhere covered with grass reaching to his horse's flanks. In passing through this region a year ago, scarcely a stalk of grass was to be seen from one end of the valley to the other. The transformation has taken place in half a score of years."

As a result of the overstocking of pastures, weedy annuals, like southern poverty grass, foxtail, squirrel-tail, and awned brome grass, spring up and take the places of the better perennial species, or the native ragweeds and verbenas spread and occupy the soil. All of these have become so plentiful that farmers remark on their greater frequency of occurrence now than in former years. Several rank growing weeds are abundant in meadows and pastures of western Iowa. Sunflower and marsh elder find in the rich alluvial soil of the river bottoms a most congenial place for development. They are especially troublesome in land that is often flooded dur- 
ing spring freshets. In addition to these plants, the pastures throughout Iowa are, especially in the fall, troubled with weeds such as goldenrod, the large yellow-flowered goldenrod (Solidago rigida) being exceedingly common in native pastures after the cattle have been running in them all summer. Sometimes these pastures present a mass of yellow. Frequently the $S$. canadensis is found in similar situations. In low-lying districts, especially in swampy ground, the rose-flowered smartweed or shoestring (Polygonum Muhlenbergii) is common. This persistent perennial produces very long, thick, stout root stocks and grows so thickly that grass does not appear. Another weed which occurs in our low, wild meadows is the thistle (Cirsium iowense), a biennial which makes very little growth the first season, but the second season sends up a large much-branched stalk and produces numerous purple flowers. The allied bull thistle (C. lanceolatum) is especially troublesome in pastures in the timber lot, frequently growing in such large masses as to become decidedly noxious. Canada thistle is common in the East and Canada. Stock carefully feed around this plant, thus permitting its seed to be sown broadcast in the field. It is occasionally found in meadows also. The meadowsunflower (Helianthus grosseserratus) is common throughout the northern states, in draws; the artichoke (Helianthus tuberosus) also occasionally occurs.

In the East, the ox-eye daisy (Chrysanthemum leucanthemum), as yet rare in Iowa, is a pernicious weed in meadows eastward. In the West the white weeds (Erigeron ramosus and E. annuus) take its place. In the South, boneset (Eupatorium) and ironweed (Vernonia) are common.

Another plant which has recently come into notice as a troublesome weed is the rib plantain (Plantago lanceolata), which has been brought into our meadows with clover seed. It is much more common in the East than 
in the West and is quite easily recognized by its perennial habit and its long leaves, which are close to the ground. The flower stalk is groove-angled and from one to two feet long. It bears a cylindrical spike of flowers somewhat like the common dooryard plantain, but much shorter. Like many of our other troublesome weeds it is a native of Europe.

Another European vagrant, the sheep sorrel (Rumex Acetosella), is widely distributed in the country. The fact that this weed spreads freely by its running roots accounts for its appearance in mats. There is a widely prevalent opinion that ground on which it occurs lacks lime; but this is far from being the fact, since the weed is very common in soils which contain large quantities of calcareous matter.

An ally of the preceding species is the curled dock (Rumex crispus). This pestiferous plant, widely distributed throughout the northern states to the Pacific coast, does much injury in meadows and pastures. The best method of destroying it is to pull it up by twisting the root and then removing it by a sudden pull or jerk. Several other species of dock are

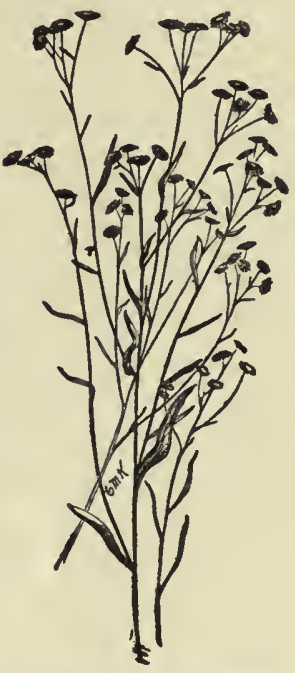

Fig. 33. White weed (Erigeron ramosus) a common weed in timothy and clover meadows in the North and East. (C. M. King.) common in low meadows, among them being the smooth dock (Rumex altissimus).

Sneezeweed (Helenium autumnale) is extremely common in low ground in many portions of Iowa. This weed has sometimes caused much alarm among stockmen, as it is poisonous. In the South the narrow-leaved species (H. tenuifolium) is abundant. 
The blue vervain (Verbena stricta), with hairy leaves and long spikes of blue flowers, is common in many pastures of the northern Mississippi valley. Yarrow is also common, not only in northern states, but across the continent, especially in dry pastures and meadows.

Two weeds of the morning glory family are very frequently found in Iowa. One, the European bindweed (Convolvulus arvensis), has made its way from Illinois and Missouri, where it is already something of a pest, and is now seen in meadows in Iowa. The other, the common morning glory (C. sepium), very closely allied to the above, is common in low meadows, where it has long been known as a persistent, troublesome weed. It differs from the European bindweed in having much larger flowers and longer twining stems. It not only shuts out the light from the grass, but its presence in hay renders the latter less valuable. There is no method of exterminating this weed except by close pasturing and preferably using the pasture for hogs. It must be taken up root and all or it will not be subdued.

Milkweed (Asclepias syriaca) is frequently troublesome in meadows of the north; the showy milkweed from Iowa to Utah and the swamp milkweed ( $A$. incarnata) are also seen in low meadows of the North.

Horse nettle (Solanum carolinense) is also frequently complained of. Allied to this is the buffalo bur (S. rostratum), a bushy annual which grows only in open places in the meadow and would not occur if the meadow were kept in good condition. It is common in the Rocky Mountain country and from Kansas to Texas.

Cowbane (Cicuta maculata), belonging to the same family as the carrot, parsnip and celery, is a frequent inhabitant of low meadows in Iowa and is easily recognized by its white flowers borne in umbels. It is one of the most deadly poisonous plants of the North, the poison residing in the root. Many cases of poisoning of human 
beings as well as of cattle have been reported in the United States. In the West there are several other kinds which are common, like the western cowbane (C. vagans).

Squirrel-tail grass (Hordeum jubatum) has long been a troublesome pest in many parts of the West, especially in Wisconsin, Illinois, Nebraska, Wyoming and Utah. It is one of our worst meadow weeds. Though originally a native of the sandy seashores from Nova Scotia to Maryland, and the upper great lakes, it has spread from the lakes to adjoining prairie country and is now troublesome in both pastures and meadows. In the former, it may be removed by cutting the plant before it is mature. It frequently causes injuries to cattle that may result in death. Broom sedge (Andropogon virginicus) is a most troublesome weed in meadows from southern Missouri, southeast to Virginia.

Sweet clover (Melilotus alba), one of the most common weeds of pastures, is regarded by bee keepers as a valuable honey plant; but in the North is little esteemed as a forage plant. In the South it is valuable for reclaiming waste land, as it grows not only on rich land, but will thrive in the poorest soil. Professors Tracy and Goff both recommend it as a soil renovator. Although occasionally useful in Iowa as a bee plant, a soil renovator, and a forage plant, we must nevertheless regard it as a weed.

A few members of the mustard family are troublesome in the pastures and meadows of Iowa. Among these are pepper grass-Lepidium apetalum and L. virginicumthe former of which is abundant, especially in timothy seed. Its brown color enables it to be easily detected.

The wild carrot (Daucus Carota) is common in the East in some clover meadows, having been introduced largely with clover seed.

The bracted plantain looks much like buckhorn, but has 
narrower leaves. It is common in Missouri, Illinois, Iowa, Nebraska and Kansas, extending east as far as the Atlantic coast.

Field dodder is common not only on native herbage clear across the continent, but also occurs on clover. The clover dodder appears in California, Utah, Colorado, Montana, Missouri, and Iowa on alfalfa and clover.

Pepper grass (Lepidium virginicum) furnishes an impurity for alsike and blue grass.

Persicaria, or lady's thumb (Polygonum Persicaria), and the two ragweeds are common in many meadows. Among the common weedy grasses are foxtail (Setaria glauca), crab grass (Digitaria sanguinalis) and barnyard grass (Echinochloa crus-galli).

On the plains and ranches in Colorado and Utah occur many bad weeds. The Russian thistle (Salsola Kali, var. tenuifolia) is easily one of the most common weeds in eastern Colorado, coming up not only in the streets, but also along roadsides and in fields. In the early days of the Russian thistle it was thought that it would prove a very troublesome weed in the more humid conditions of our country. Thus far it has not, but in the West it has found ideal conditions for development. Another weed which has become abundant is the tumbling mustard (Sisymbrium altissimum), which is found in many places. It has light yellow, mustard-like flowers, and later stiff pods without leaves. Sweet clover grows everywhere along roadsides and streets in eastern Colorado and stands drought well. On some of the foothills and streets of the eastern slope of the Rockies a species of brome grass (Bromus tectorum) is becoming abundant. It is an annual which grows with very little moisture and is crowding out many more valuable grasses, and alfalfa. It is particularly common near Colorado Springs, Salt Lake Basin and in California. It has little value for forage purposes; the hay is light, and moreover the plant is injuri- 
ous to stock in much the same way that squirrel-tail is; $i$.e., it gets into the mouth, producing inflammation and causing severe ulceration. Squirrel-tail grass is abundant where seepage water occurs, and like the brome grass just mentioned causes much injury to stock. Little can be done to check it as long as it isi allowed to go to seed.

In Utah another annual brome grass, the quaking brome (Bromus bri aeformis), is often seen, also several species of squirrel-tail grass (Hordeum jubatum, $H$. caespitosum), common in the East, and wild barley ( $H$. murinum).

Storksbill (Erodium cicutarium) is common on much of the western country to California. Wild oats (Avena fatua) is frequently seen.

In most meadows of Utah there is an abundance of a sprecies of thistle (Cirsium scariosum). It is a large stocky plant with very spiny, light-colored leaves and light purple flowers. In some places the green hellebore (Veratrum viride) is common.

In low meadows or sandy, moist meadows, of the North the common horsetail (Equisetum arvense) is abundant and troublesome. In the Pacific Northwest another large species is common. The common brake (Pteris aquilina) is common and troublesome in the same region. Both the brake and horsetails are poisonous.

Weeds of Grain Fields: Small Grains.-The kinds of weeds found in small grain fields vary with the locality; although some kinds are quite universal. Among these are mustard, corn cockle, cowherb and vetch. Many others are local. Among these may be named Russian thistle, in the West; wild garlic, pennycress, mustard, tumbling mustard, foxtails, crab grass, germander, smartweed, lady's thumb, corn gromwell, Canada thistle in the East and Canada; perennial sow thistle in Minnesota and North Dakota; ragweed, milkweed, artichoke, 
morning glory, wild oats, cocklebur, chess (Bromus secalinus), cockle, cowherb, vetch, rose, etc.

Corn.-Many of the foregoing weeds also occur in corn fields. To them we might add velvet weed, shoofly, sida, chicken corn, horse nettle, shoestring, meadow sunflower, cocklebur, artichoke, large ragweed, nut grass, quack grass and buffalo bur.

Weeds of Gardens.-The more important weeds of gardens are prickly lettuce, annual sow thistle, lamb's quarter or goosefoot, purslane or pusley, lady's thumb, pigweed, five-finger, crab grass, horseweed, quack grass and nimble will.

The character of weeds of gardens naturally differs in various parts of the United States. In New England and the Central States such weeds as goosefoot, fall dandelion, smartweed, sheep sorrel, crab grass, common mouseear chickweed, purslane, celandine, shepherd's purse, horse-radish, sweet clover, milk spurge or milk purslane, cheeses, wild carrot, blueweed, corn gromwell, henbit or dead nettle, speedwell, small ragweed, toadflax, burdock, bootjack, prickly lettuce, green foxtail, pigeon grass, buttercups and Canada thistle, chicory, quack grass, are all common weeds.

The weeds of the central northern Mississippi vallev are much the same, except the larger ragweed, squirreltail, Pennsylvania smartweed, bindweed or wild buckwheat (Polygonum Convolvulus); dropseed grasses ( $\mathrm{Muhl}$ enbergia mexicana and $M$. glomerata), are abundant, and occasionally night-flowering catchfly (Silene noctiflora). In the latitude of St. Louis, a wild bean (Strophostyles pauciflora), the southern morning glory (Ipomoea hederacea), European bindweed (Convolvulus arvensis), boneset (Eupatorium scrotium), Mexican tea, spiny pigweed, Indian mallow or velvet weed, galinsoga, ironweed ( Vernonia noveboracensis), aster (Aster Tradescanti and A. salicifolius), goldenrod (Solidago serotina); the boneset, 
asters, goldenrod and European bindweed, are perennial. Marsh elder (Iva ciliata), poverty grasses (Aristida dichotoma), dead nettle or henbit (Lamium anplexicaule), are abundant annuals. The Virginia plantain (Plantago virginica), pokeweed (Phytolacca decandra), Carolina crane's-bill (Geranium carolinianum), turkey-foot grass (Eleusine indica), and sida (Sida spinosa) are the common weeds; the large and small ragweeds should also be included in this list.

From western Iowa to Denver the weeds are much the same as in Iowa and New England, except the false ragweed or marsh elder, Mexican fireweed, yellow and white sweet clover, Russian thistle, buffalo bur, vegetable oyster plant, wild licorice, tarweed or rosin weed (Grindelia squarrosa), perennial ragweed (Ambrosia psilostachya), prickly poppy (Argemone intermedia), woolly thistle (Cirsium canescens), Fremont's goosefoot (Chenopodium Fremontii) and annual sunflowers (Helianthus annuus and $H$. petiolaris) are common. The latter are abundant from western Iowa to Texas. The cleome is abundant on the plains.

In the interior basin, awned brome grass, conium, wild barley, peppermint, caraway, horehound (Marrubium vulgare), pineapple weed and black medic are among the common weeds.

In California the more important weeds are wild licorice, spiny cocklebur, wild heliotrope, crowfoot grass. crab grass, milk thistle, storksbill, bur clover, tarweed, wild carrot, etc.

In Maryland and Virginia, wild onion, dandelion, wild carrot, prickly lettuce, sweet clovers, horseweed, cocklebur, Mexican tea and pigweed are common.

In the Gulf states the narrow-leaved sneezeweed, pigweed (Boerhaavia), sida, morning glory (Ipomoea hederacea), croton (C. capitatus and C. monanthogynus), crab grass, etc., are the common weeds, and westwara in 
Texas the buffalo bur; the prickly poppy (Argemone mexicana) is one of the most common weeds.

Many of these annual weeds are easily exterminated by cultivation, but attention must be paid to weeds which occur in waste places where they produce seeds in enormous quantities. Weed seeds often retain their vitality for a considerable period of time. Even though the first crop is removed, a second crop appears from the seeds buried somewhat deeper in the soil.

Weeds of Vacant Lots.-The vacant lots of all parts of our country are a continual menace to the agricultural community. Many of our worst weeds start in the city. The writer has observed the spreading of orache (Atriplex) from a small beginning in an Iowa city over a considerable area. There are hundreds of acres of Canada thistle in Chicago, and in some streets much of the perennial sow thistle, which is such a menace to the agriculture of Canada, the eastern states, northern Minnesota and North Dakota. The bouncing bet and toadflax are spreading rapidly to the adjacent country from such cities as St. Paul, Minnesota, La Crosse, Wisconsin, and Chicago. The unoccupied lands are great weed patches and in most cases are very unsightly.

In an interesting article on "Weeds of Cities and Towns" by Lyster H. Dewey, the statement is made that "the weeds of cities and villages are usually of the migratory class, cosmopolitan in character, and capable of thriving under a wide range of environment. According to the early European works on botany, plants from Asia, adventive in Europe, usually appeared first in cities. Many of these plants are found about the cities and towns of this country. Others are native plants which have withstood the changed conditions due to cultivation and have acquired a weedlike habit. In the eastern cities and in those on the Pacific coast Old World species predominate, while in the cities of the interior, 
especially in those west of the Mississippi river, there is a larger proportion of native plants. The species vary in different cities, in different years, and in different sea6ons."

These weeds can be removed by sowing these lots and vacant areas with clover and grasses. These plants will effectually prevent the growth of many weeds, except the annual spear grass (Poa annua), dandelion, wild onion (Allium vineale), star of Bethelem (Ornithogalum umbellatum) and cat's-ear (Hypochaeris); or they can be utilized for the growth of vegetables, like the potato.

Where there are large areas, these weeds can be kept down by allowing sheep to graze; this method is followed in New York and Philadelphia. These animals are excellent lawn mowers. The driveways of parks and walks can be kept clean by spraying with iron sulphate or some other herbicide; however, the iron sulphate will be more effective than most of the other herbicides. The method has been described in full in another connection.

In many states there are laws on the extermination of weeds, and while they may be enforced in the country, no attention is paid to them in cities. The municipal authorities should enforce the laws. It may be necessary to appoint a weed commissioner who shall work under the authority of the street or park commissioner. Dewey suggests that "a few good examples, which may be produced through individual effort or by the united action of a small community, will demonstrate the practical utility of the work and lead to its extension. Examples of this kind are now found in many villages and suburban towns. If the practice can be made general in the cities and towns throughout the country it will cut off one of the principal avenues for the introduction of foreign weeds."

Roadside Weeds.-There is very little excuse for the appearance of many of the weeds that appear along roadsides, the character of these differing only with the local- 
ity. Among the most conspicuous roadside weeds are the greater ragweed, small ragweed, meadow sunflower, artichoke, bull thistle, dog fennel, beggar-ticks, marsh elder, fetid marigold, velvet weed, Jimson weed, cocklebur, mustard, mullein, Canada thistle, woolly thistle, squirreltail grass, wild barley, sweet clover, annual brome grass, black medic, bur clover, dodder (the last three especially common in Colorado), tumbling mustard, Russian thistle, fireweed (especially common in the West), Mexican poppy (Texas), capitate croton (Missouri to Texas), sneezeweed, and buffalo bur (common from Colorado to Texas). Sunflower and marsh elder are very frequently seen in Kansas, Nebraska, the Dakotas and Colorado.

Weeds of Yards.-The weeds of yards, especially of barnyards, also vary greatly. In nearly all cases they are such as can stand considerable tramping over, or else they are weeds that are avoided by stock, because of siome injurious properties residing in the plants. In the North the most common barnyard weeds are dog fennel, barnyard grass, cheeses or small mallow, Jimson weed, dock, fetid marigold (in Iowa, Nebraska to Kansas), smartweed and dooryard knotweed. In the Southwest, buffalo bur and smartweed are common.

Weeds of Lawns.-Blue grass, during the dry season, may become weedy. In the greater part of the Mississippi valley, the most common weed on lawns is the smooth crab grass which fruits so closely to the surface of the ground that the lawn mower will not catch all of the seeds. Yellow foxtail or pigeon grass is also common where the lawn is not properly cut. Chickweed is one of the most common weeds in the North. Dandelion is one of the most common weeds in lawns in the Northwest. Cat's-ear (Hypochacris radicata) is common on the Pacific coast, in Washington and Oregon. 


\section{CHAPTER VIII. \\ POISONOUS WEEDS}

A great many people are ignorant of the presence of poisonous plants growing in their neighborhood. In the list given below are some of the most common species. While some of these are found more frequently than are others, it is also true that some in the list are more virulently poisonous than others. In wet places in the North, the cowbane is one of the most poisonous of weeds; the fleshy roots with a pungent odor are eaten, people mistaking them for parsnips. The hemlock of the ancients, a common plant in the West, contains a deadly poison. The seeds of Jimson weed are also poisonous. The nectar in the flowers of this weed and of Wright's datura have caused the death of children.

In the list appended below,

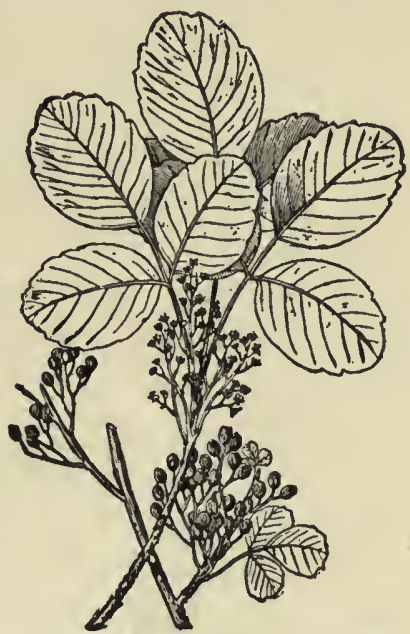

Fig. 33a. California poison ivy ( $R$ hus diversiloba). Many people poisoned by touching the plant. (U. S. Dept. Agrl.) the more poisonous species are printed in bold face type.

Anemone or wind flower, black henbane, black locust, black nightshade, bloodroot, bouncing bet, buckwheat, bunchflower, bulb-bearing hemlock, calycanthus, caper, celandine, choke cherry, cockleb Ir, common brake, common juniper, corn cockle, crimson clover, crowfoot, cursed crowfoot, cypress spurge, 
aarne!, elderberry, flax, flowering spurge, fly agaric, hellebore (green and false), hemp, hogwort, horse chestnut, horse-radish, horsetail, Indian hemp, Indian tobacco, Jimson weed, Kentucky coffee tree, large blue flag, larkspurs, lepiota, lily of the valley, lima bean, mandrake, marsh marigold, monkshood, moonseed, mustard, needle grass, opium, osage orange, partridge pea, pasque flower, peach, poison hemlock, poison ivy, pokeweed, prickly poppy, purple foxglove, purple Jimson weed, ragweed, rattlebox, rose, sleepy grass, smartweed, sneezeweed, sorghum, spotted spurge, spreading dogbane, stemless loco weed, stinging nettle, stonecrop, swamp camas, sweet clover, tansy, some toadstools, tobacco, tree of heaven, water hemlock, water parsnip, white snakeroot, wild barley, wild black cherry, wild indigo, wild oats, wormseed, Wright's datura, yellow lady's slipper, yew.

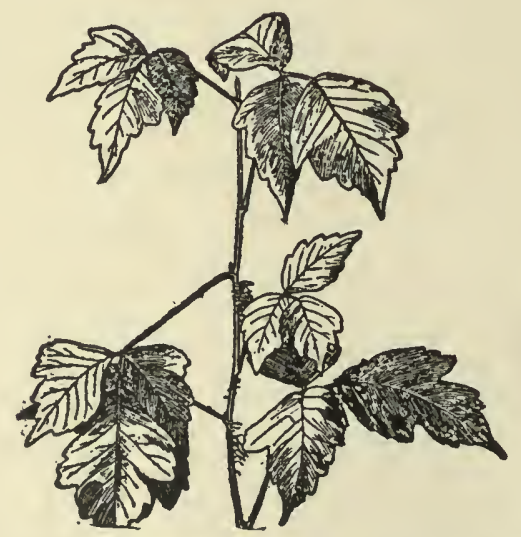

Fig. 33b. Poison ivy (Rhus Toxicodendron), common in eastern North America. Many people are sensitive to its poison. 


\section{TABLE OF NOXIOUS WEEDS}

In the table which follows the most troublesome weeds of North America have been given. No doubt there are many other plants which should be classified as weeds, but it is difficult to always draw a sharp line; moreover, it is a difficult matter sometimes to determine the worst weeds for a given locality and even more difficult to determine the worst weeds for the entire country. A weed may be very bad in Iowa and yet comparatively harmless in Missouri, Arkansas, and Florida. For instance, the sow thistle is certainly a very bad and aggressive weed in the Canadian Northwest and on the borders of North Dakota and Minnesota; the orange hawkweed is a troublesome weed in the New England states and New York, the same is true of the ox-eye daisy, but it is not troublesome in Iowa, Nebraska, Kansas, or Missouri. Quack grass is an extremely troublesome weed from: the New England states to Minnesota and is becoming troublesome in northern Iowa.

Some years ago Dr. Byron D. Halsted published a paper giving a scale of points of our worst weeds. 1 The report was based upon reports received from more than one hundred replies from different parts of the United States. It was found that the following weeds were reported the most frequently:

Canada thistle ro times, pigweed ro times, purslane I4 times, cocklebur six times, and so on. That is to say the correspondents mentioned these as the worst weeds in their particular locality.

Dr. Halsted considers the following as important in

1 Proc. Soc. Prom. Agrl. Scl., 1889:43. 
determining the scale of points: $I$, the recognition of the seed; 2 , separation of the seed; 3 , recognition oi plant; 4 , prevalence; 5 , robbing soil; 6 , seeding capacity; 7 , dissemination; 8 , vitality of seed; 9 , longevity; Io, root and stem propagation; II, obnoxious qualities; I2, forage value; I3, resist eradication; I4, aggressiveness; I5, harbor fungi; I6, harbor insects; I7, soil habitat; I8, climate habitat; I9 and 20, miscellaneous. Dr. Halsted gives a tabulated scale showing the characters of the worst weeds of the country as follows:

\begin{tabular}{|c|c|c|c|c|c|c|c|c|c|}
\hline & & 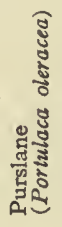 & 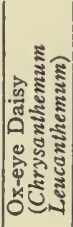 & 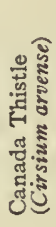 & 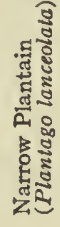 & 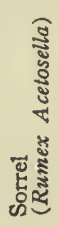 & 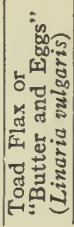 & 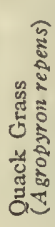 & 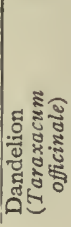 \\
\hline \multirow{20}{*}{$\begin{array}{r}1 \\
2 \\
3 \\
4 \\
5 \\
6 \\
7 \\
8 \\
9 \\
10 \\
11 \\
12 \\
13 \\
14 \\
15 \\
16 \\
17 \\
18 \\
19 \\
\& \\
20\end{array}$} & Recognition of Seed... & 4 & 4 & 4 & 4 & 3 & 3 & 5 & \\
\hline & Separation of Seed.... & 1 & 4 & 4 & 4 & 2 & 3 & 4 & 4 \\
\hline & Recognition of Plant......... & 2 & 3 & 4 & 3 & 3 & 2 & 3 & 1 \\
\hline & Prevalence............... & 3 & 3 & 4 & 4 & 4 & 3 & 3 & 3 \\
\hline & Robbing Soil........ & 3 & 5 & 5 & 2 & 2 & 2 & 4 & 2 \\
\hline & Seeding Capacity........... & $\mathbf{5}$ & 5 & 5 & 3 & 3 & 2 & 1 & 3 \\
\hline & Dissemination,$\ldots \ldots \ldots \ldots$ & 1 & 4 & 5 & 2 & 2 & 1 & 1 & 5 \\
\hline & Vitality of Seed........ & ? & ? & ? & ? & ? & $?$ & ? & ? \\
\hline & Longevity $. . \ldots \ldots \ldots \ldots, \ldots, \ldots$ & 2 & 5 & 5 & 4 & 4 & 3 & 4 & 4 \\
\hline & Root and Stem Propagation. & 0 & 3 & 5 & 1 & 1 & 1 & 5 & 1 \\
\hline & Obnoxious Qualities......... & 0 & 3 & 5 & 1 & 1 & 0 & 0 & 0 \\
\hline & Forage Value............ & 4 & 4 & 5 & 2 & 4 & 3 & 3 & 4 \\
\hline & Resist Eradication........... & 3 & 4 & 5 & $\overline{1}$ & 1 & 1 & 5 & 1 \\
\hline & Aggressiveness........... & 4 & 5 & 5 & 1 & i & 2 & 5 & 3 \\
\hline & Harbor Fungi..$\ldots \ldots \ldots \ldots \ldots$ & 1 & 0 & 0 & 0 & 0 & 0 & 1 & 0 \\
\hline & Harbor Insects.$\ldots \ldots \ldots \ldots$ & 0 & 0 & 0 & 3 & 0 & 0 & 0 & 3 \\
\hline & Soil Habitat.............. & 3 & 3 & 4 & 2 & 2 & 2 & 3 & 3 \\
\hline & Climate Habitat........... & 4 & 4 & 4 & 2 & 2 & 2 & 3 & 4 \\
\hline & Miscellaneous. . . . . . . . . & 4 & 5 & 5 & 4 & 3 & 2 & 4 & 1 \\
\hline & Total Points............ & 44 & 64 & 74 & 43 & 38 & 31 & 54 & 46 \\
\hline
\end{tabular}

For the state of Iowa the weeds given in the Iowa Weed Law are the most injurious with the possible exception of the squirrel-tail; they are as follows: Quack grass, Canada thistle, cocklebur, wild mustard, sour or 
curled dock, smooth dock, buckhorn, or ribbed plantain, wild parsnip, horse nettle, velvet weed or button weed and burdock.

The Canada thistle, quack grass, horse nettle, cocklebur, and squirrel-tail grass are the most injurious in Iowa, while Dr. Halsted gives some of the worst weeds found in the state of New Jersey as follows: Canada thistle, wild carrot, docks, ox-eye daisy, ragweed, sorrel and narrow plantain.

In $W$ isconsin the worst weeds are quack grass, Canada thistle, mustard, dock, ragweed, wild carrot in some places, and cocklebur. The worst weeds for Indiana, according to Mr. J. R. Campbell, are white weed in clover and timothy meadows, cocklebur in corn fields, horse nettle, buckhorn, and in the southern part of the state wild garlic, while in Kentucky the star of Bethlehem has become a most pestiferous weed in gardens and fields. In parts of Canada, especially the province of Manitoba, they consider the Canada thistle, perennial sow thistle, wild oats, and marsh elder to be the most troublesome of their weeds. H. L. Bolley, in his account of the weeds of North Dakota, gives the following as some of the most troublesome: Kinghead, Canada thistle, French weed, mustard, and wild oats. Dr. Millspaugh reports the oxeye daisy, yarrow, broom sedge, and blue thistle as the worst weeds in the northeastern part of West Virginia. The broom sedge here listed is generally a troublesome weed in many parts of Virginia and other southern states, where it is considered one of the worst of weeds, as it is also so considered in Ohio by Professor Selby. Dr. A. Nelson considers Russian thistle, squirrel-tail grass, cockle, Canada thistle, bull thistle, buffalo bur, prickly lettuce, among the worst weeds of Wyoming. 


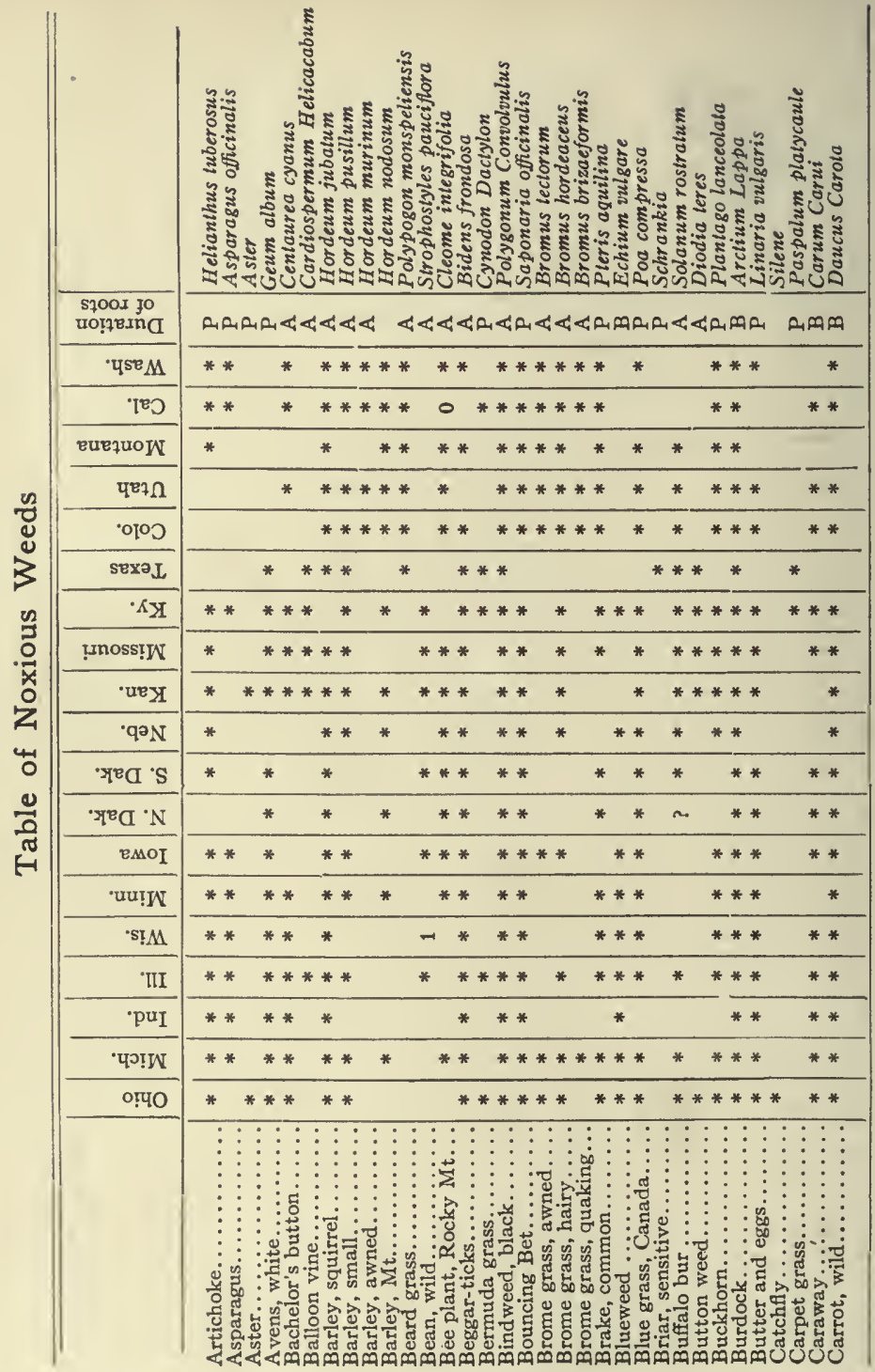




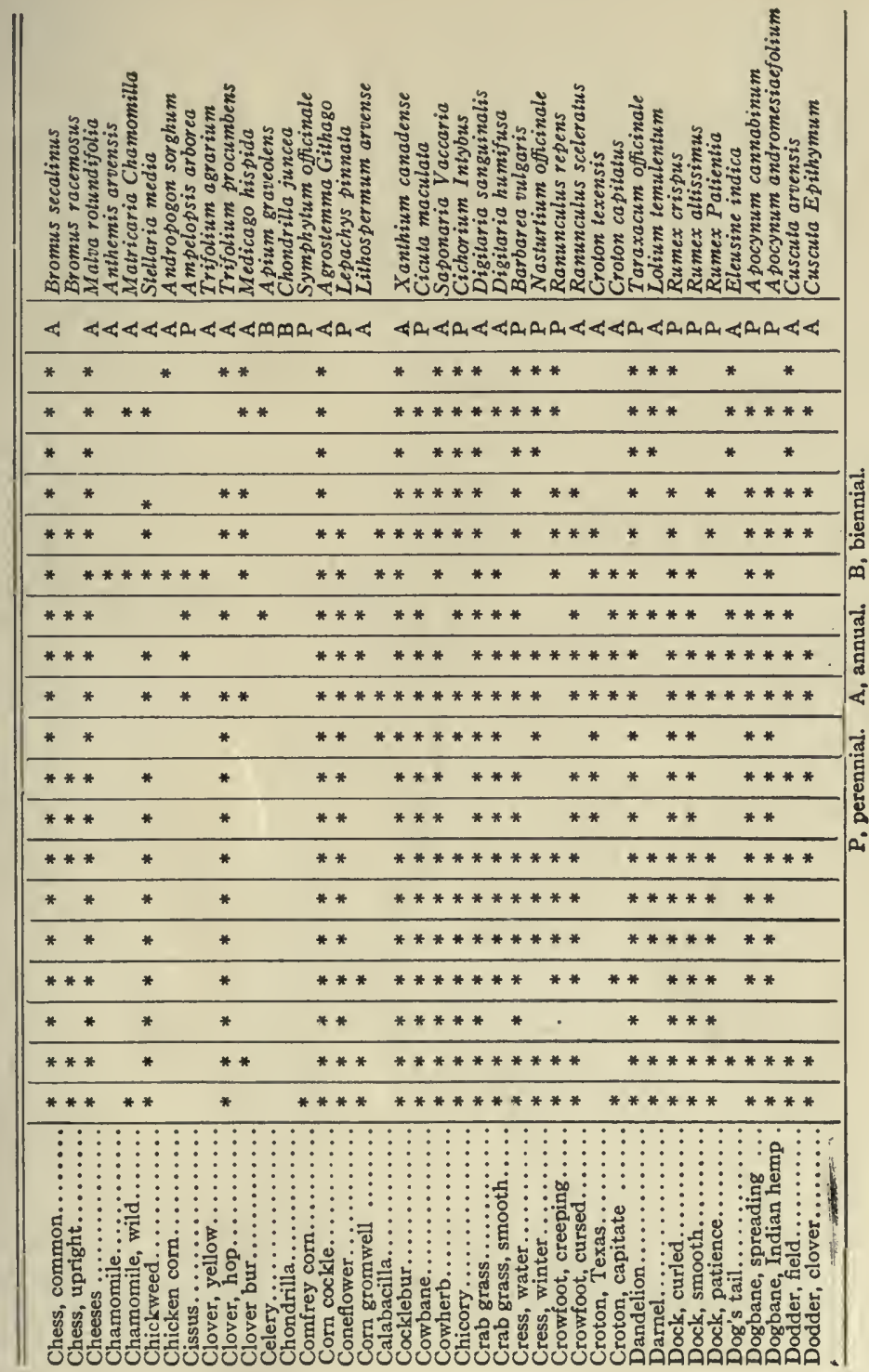




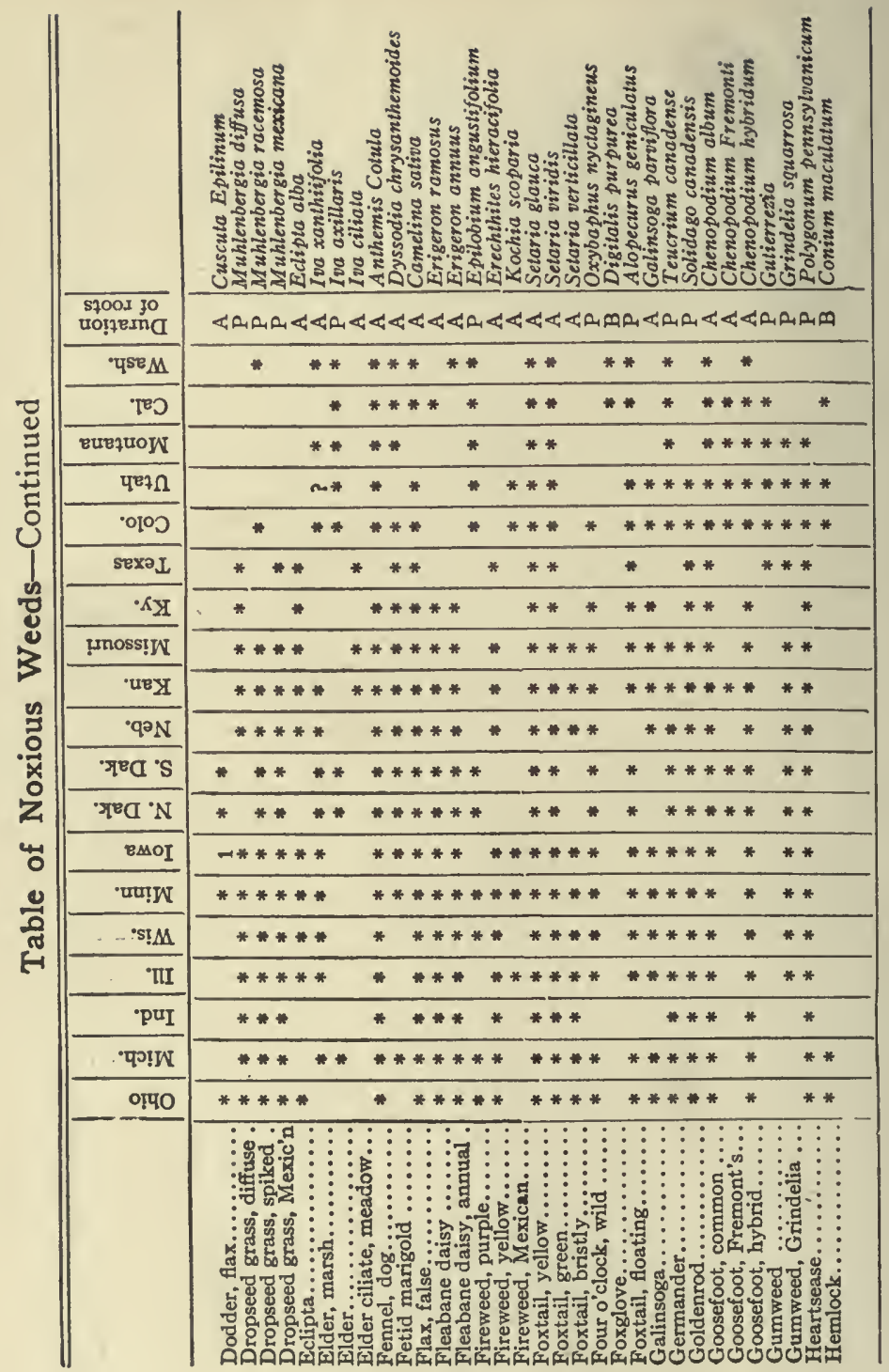




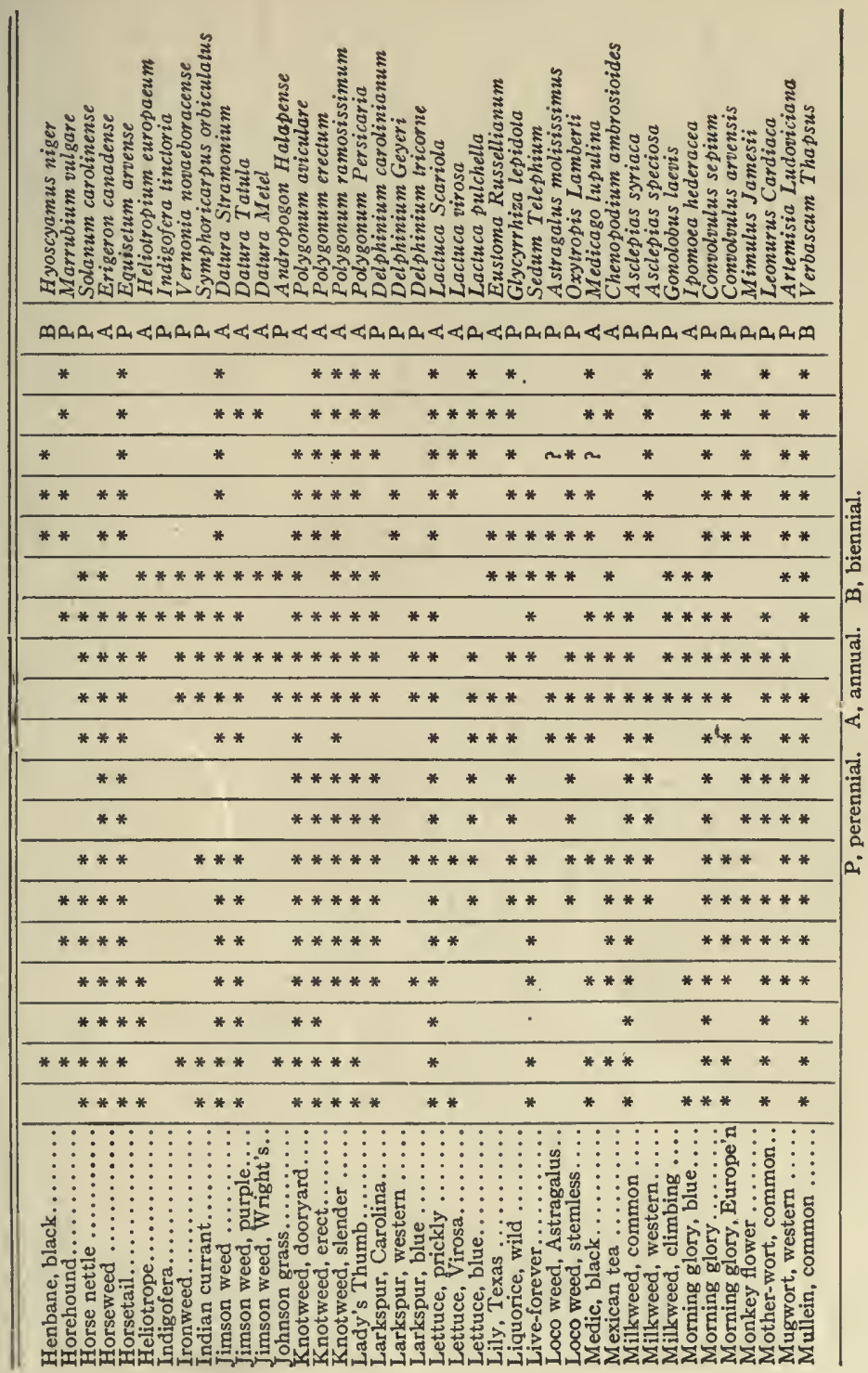




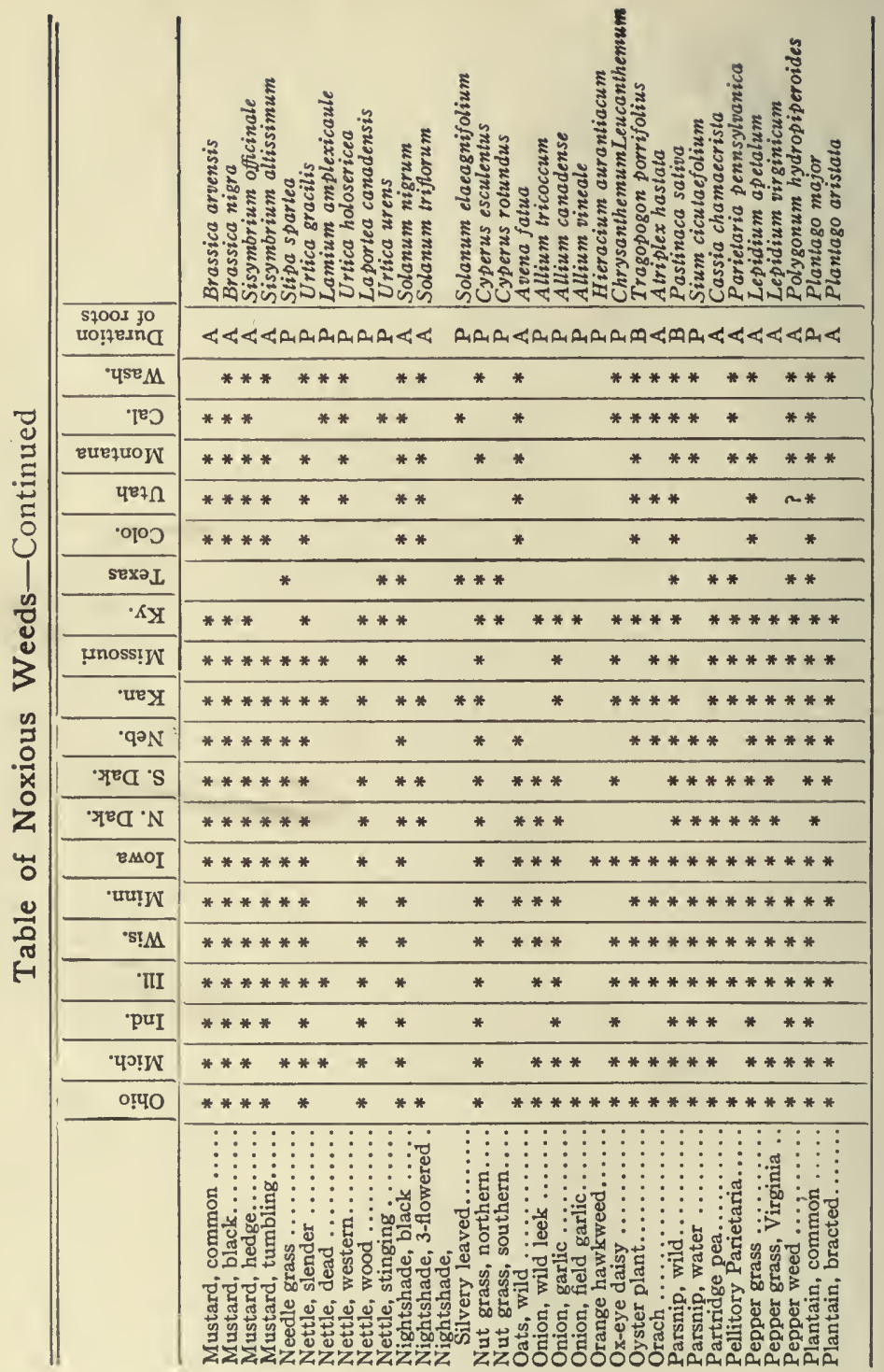




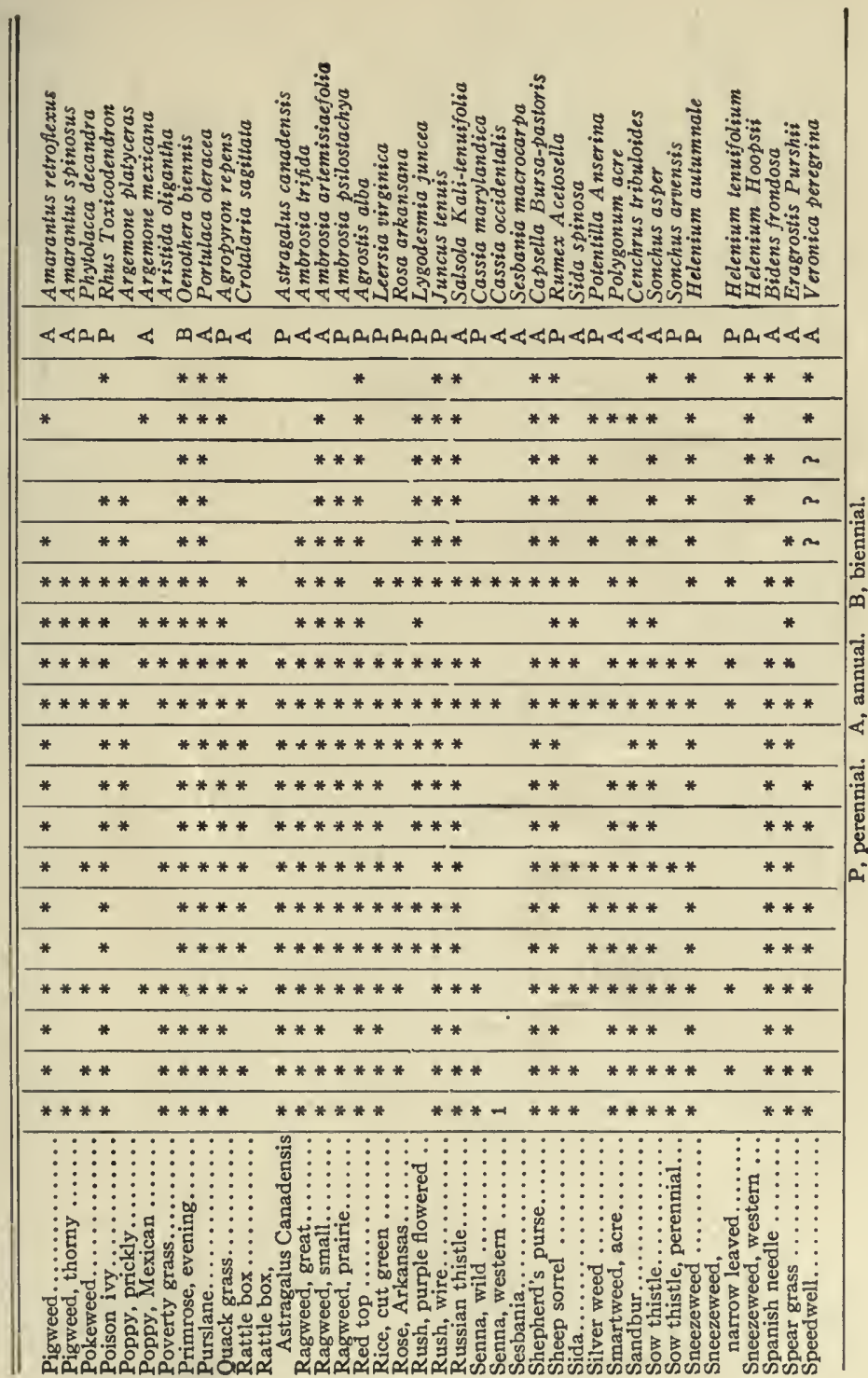




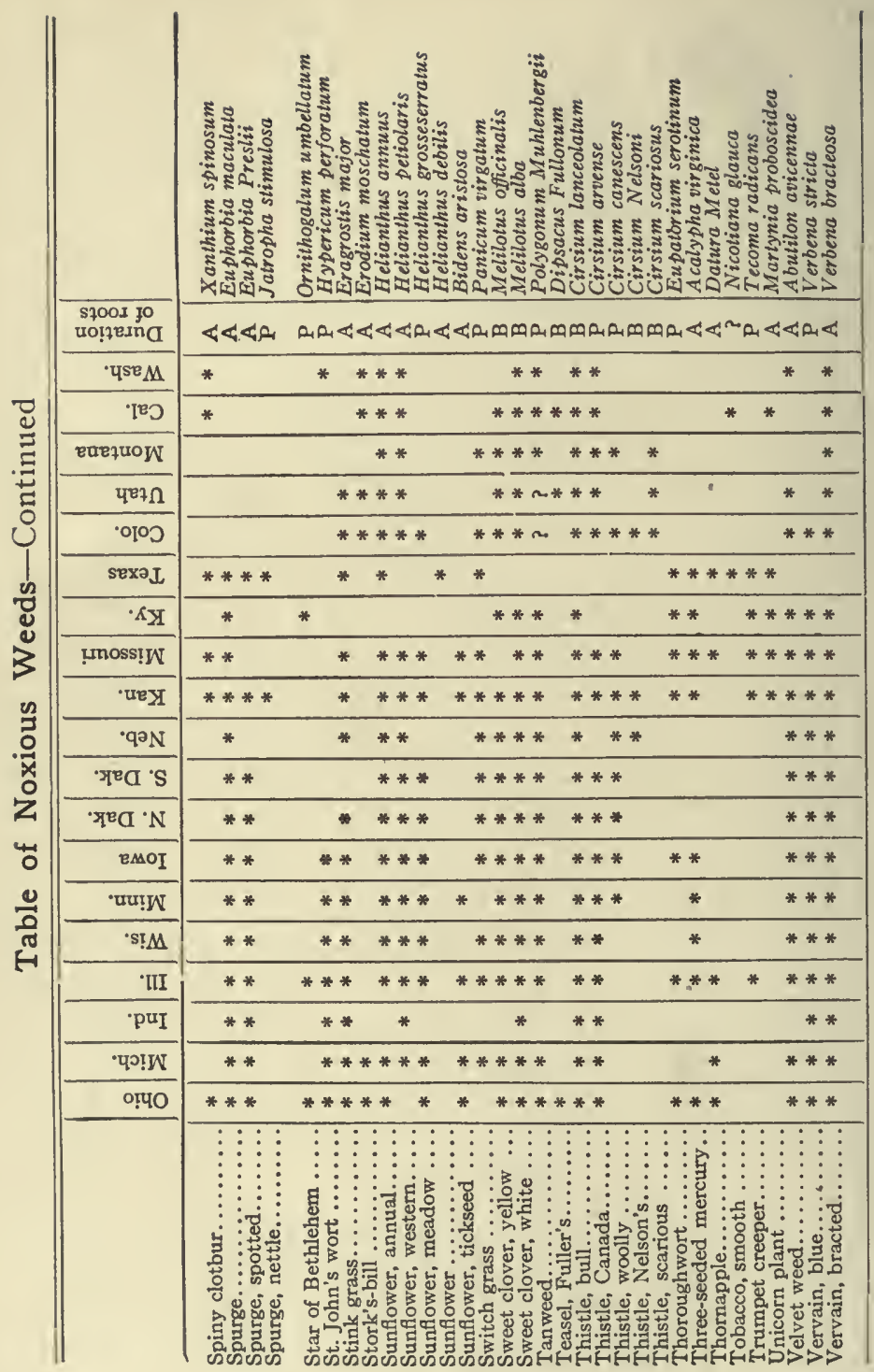




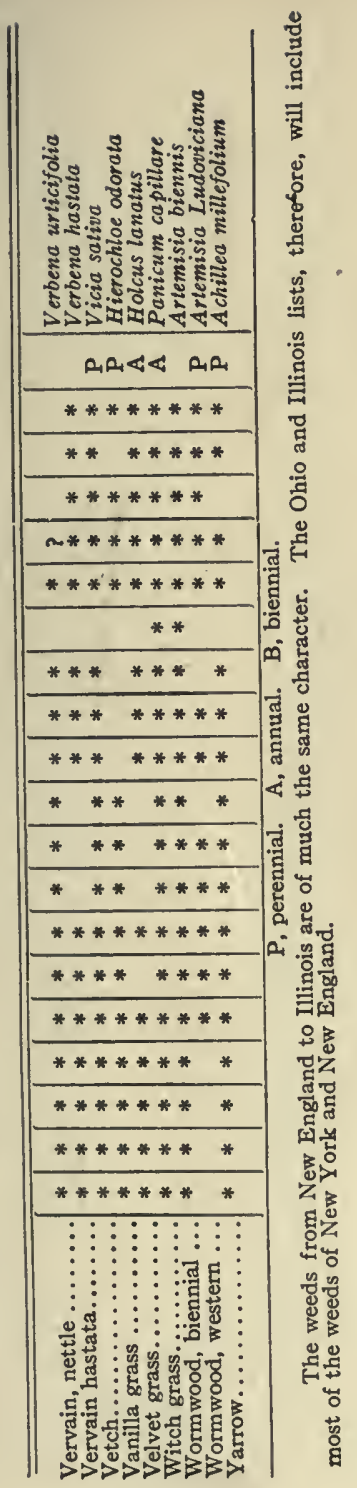




\section{CHAPTER X.}

\section{MIGRATION OF WEEDS}

The study of the abundance of weeds and their distribution is one of great importance to the cultivator of the soil. Many of our common weeds occur from the Atlantic to the Pacific. Many of them are of European origin. Some weeds are native to the soil; others are tropical in origin. It will be found from the list of weeds appended that many of them are common from the Gulf of Mexico to British America. It is also true that Texas has some of its own weeds; that the eastern Gulf states have some peculiar weeds; that the states west of the Missouri River to the Rocky Mountains also have their own characteristic weeds and some localized weeds are found upon the Pacific coast.

It may be interesting to observe in this connection that some weeds require a considerable length of time before they are permanently established and become a part of our flora. In other instances certain weeds are crowded out. During recent years the writer has found very little evidence of the black mustard in this state, most of it being replaced by the charlock, or wild mustard of our oat fields. In Utah the awned brome grass has crowded out the quaking brome grass. In I898, when the writer visited the region of Salt Lake and Ogden he found quaking brome grass the predominating grass on the hillsides, but now the hillsides are covered with the awned brome grass and very little of the quaking brome grass could be seen.

Our eastern weeds are in a large part native to Europe, but there are a number native to Iowa, while others have come from the South and West. The question of 
migration of weeds is an interesting one. In the East the European weeds predominate. In the Southwest and the prairie states west of the Missouri many of the troublesome weeds are indigenous to the soil. I can recall but a few troublesome weeds in Texas that have come from Europe. The Texas weeds are either of tropical origin or else indigenous. However, there are some troublesome European weeds in Texas, but they do not cover the

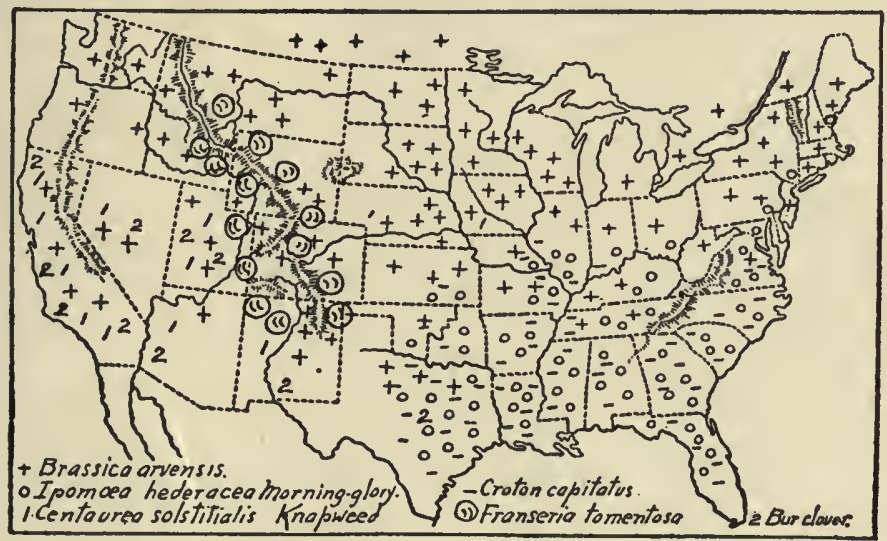

Fig. 33c. Distribution of some weeds. Mustard (Brassica), morning glory, etc. (C. M. King.)

landscape as they do in the North and East. The narrow leaf sneezeweed is a dominant weed everywhere throughout the state; and the buffalo bur, which is indigenous to the plains from western Texas to Colorado, is one of the dominant weeds. These weeds have largely spread since the rebellion, I865. In the West, particularly Utah and the mountainous countries, the scarious leaf thistle is at once a dominant species, although in places it vies with the bull thistle and in all clearings of Oregon and Washington the fireweed (Epilobium angustifolium), covers thousands of acres, while with it we may find patches 
of foxglove, pansy, and a great deal of velvet grass and much Canada thistle, besides numerous other plants which are carefully cultivated in the eastern states for ornamental purposes.

Dr. Gray has somewhere said that most of the troublesome weeds of western Europe originated in the East. It is certainly true that as conditions are prepared, weeds spring into existence. Such plants as are best adapted to stand adverse conditions assert themselves and become the pests of the farmer.

Annual weeds seem to have a better chance to adapt themselves than perennial. Of the annual weeds we may mention the purslane, Jimson weed and Indian mallow.

It does not require much botanical knowledge to recognize the similarity of the flora of our "great plains." Many of the prairie plants are common from Texas to Manitoba. The compass plant (Silphium laciniatum), buffalo bur (Solanum rostratum), common sunflower (Helianthus annuus), etc., are alike common to the prairies of Texas, Kansas, Nebraska and the Dakotas.

It is remarkable how rapidly European weeds have spread in parts of South America. In the neighborhood of Buenos Ayres, are found bur clover (Medicago hispida), its allies, and a composite (Silybum marianum), which has also become noted as a pest in California; Cynara cardunculus covers the pampas for miles. The European grasses, like the perennial rye grass (Lolium perenne), squirrel grass (Hordeum murinum) and other wild barleys ( $H$. pratense) have rapidly taken the place of native grasses. The interesting observation has been made in South America and Australia, that indigenous (native) plants have been crowded out by closely related European species. In Australia, common sow thistle (Sonchus oleraceus), a truly cosmopolitan weed, has established itself in low grounds near streams and has crowded out a native species of sonchus. It is possible that some of 
our native plants are affected in this way. Common purslane (Portulaca oleracea) has without doubt in some places replaced native forms. Bull thistle (Cirsium lanceolatum) without doubt trespasses on the ground of some of our native species. C. altissimum, $C$. iowense and C. discolor are undoubtedly affected in this way. These thistles are certainly less abundant where bull thistle occurs. In Manitoba the Canada thistle is much more abundant than th bull thistle. In places it occurs not only in fields, but in the woods. The sow thistle (Son-

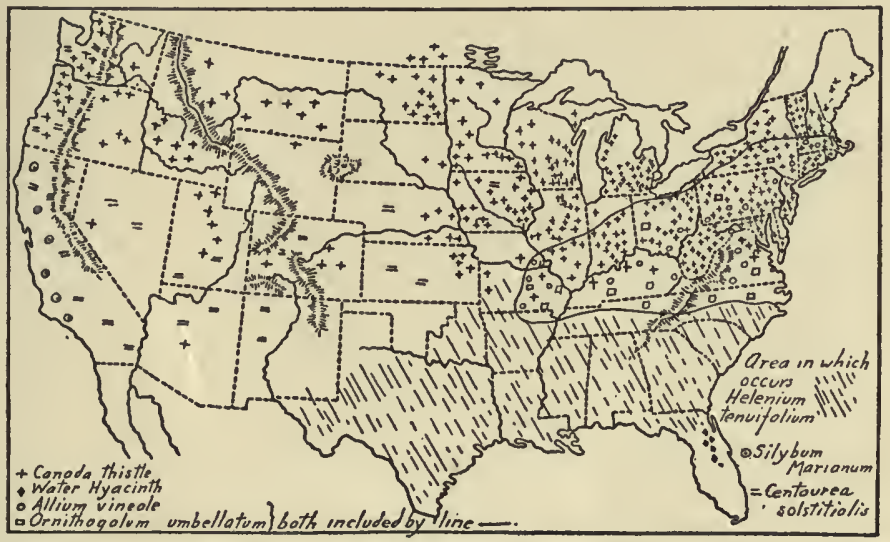

Fig. 33 d. Distribution of some weeds. Canada thistle, etc. (C. M. King.)

chus arvensis) is abundant everywhere in fields. There is little of the annual species ( $S$. olcraceus).

Most of our common weedy plants are of European origin. This is true for certain parts of the United States only, notably New York, Massachusetts, Ohio, Illinois, and other states that belong to the North Atlantic section. Yet the weeds of the interior region, the territory embracing our prairies, include a surprising number of native plants that are weedy in their nature. A few of the 
European weeds are, however, great pests. Tumble weeds (Cycloloma atriplicifolium and Corispermum hyssopifolium) and ragweed (Ambrosia trifida) may be mentioned among the troublesome weeds of the West. The preponderance of these weeds is possibly due to the newness of the country, or it may be because of the plasticity of the plants themselves or on account of certain climatic conditions. In southern Atlantic states there is a surprising number of weeds that are of tropical origin. Among these are the spiny amaranth (Amaranthus spinosus), Mexican tea (Chenopodium ambrosioides), senna (Cassia occidentalis), common morning glory (Ipomoea purpurea) and $I$. hederacea. Quite a number have come from India, as Jimson weed (Datura Stramonium), heliotrope (Heliotropium indicum), etc. Others are European.

Turning to the weeds of the Pacific coast, it may be said that its weed flora is entirely different. Dr. Hilgard, in an interesting series of ,articles, "The Weeds of California," in Garden and Forest, says:

"The broad fact in the premises that first strikes the newcomer in California is that a number of plants that are subjects of careful culture east of the Rocky mountains, as well as in Europe, and which quickly succumb when deprived of artificial protection there, are here among the most persistent and obnoxious weeds; while very many of those that are troublesome in the Atlantic region are conspicuously absent on the Pacific side. Radish, beet, celery, carrot, are conspicuous weeds. The smartweeds (Polygonum) are almost entirely absent on the Pacific coast. Amaranths flourish. Pusley, so troublesome in eastern states, has appeared in but few localities. As yet it has made no headway as a troublesome weed. Bur clover (Medicago denticulata), so troublesome in South America, was one of the earliest of European introductions in California, and is a great pest." These illustrations suffice to show the differences 
in the character of the weed flora in various parts of the United States.

Of the cosmopolitan weeds, shepherd's purse (Capsella Bursa-pastoris), occurs everywhere in Europe, Persia, India, Japan, United States, Chili, South Africa and Canada. Pusley occurs in India, Egypt, Europe, South Africa, Japan, China, Java and Philippine Islands; horse weed (Erigeron canadensis), everywhere in the United States from Maine to California, Brazil, South Italy, Russia, Sweden, Persia, North India, South Africa. It is sometimes a very difficult matter to decide whether plants are strictly native to a country or have been introduced, so thoroughly have they established themselves. Pusley is an excellent illustration. It is believed to be a native to the southwest.

Lines of Travel.-Weeds in their migration have followed certain well-defined lines of travel. The floras of our Atlantic states mention the occurrence of certain weeds commonly found where the ballast material was discharged. The list of ballast plants on the Atlantic and Pacific coast is constantly increasing.

In speaking of the means of transportation of weeds, Dewey says that the routes of transportation are indicated by the names, ballast plants, roadside weeds, weeds along the towpath, and railway weeds. Mr. Dewey says: "One hundred and three species were taken in ballast from Buenos Ayres to New.Zealand within a period of a few years."

There is no doubt that the Crusaders brought many weeds back from western Asia into Europe. Thus plants like the horse-radish, mustard or charlock, hemp (Cannabis sativa), are Asiatic plants. Kabsch notes that most of the weeds of cereal crops like Centaurea Cyanus, Agrostemma Githago, Raphanus Raphanistrum and Myagrum sativum are foreign to Europe. But Europe has also received a number of American weeds from us, like the 
Erigcron canadensis, the common horseweed. The Oenothera biennis became a settler of Padua, Italy, in I812; the Erigeron canadensis near Paris in 1835 . Our common rice cut grass (Leersia oryzoides), according to Buchenau, made its appearance in Italy many years ago.

The chicory was introduced near Dorchester, Mass., in 1875 , and since then has spread chiefly through the northern states. The ox-eye daisy was carried to Rhode Island about 1815 , and since then has spread throughout

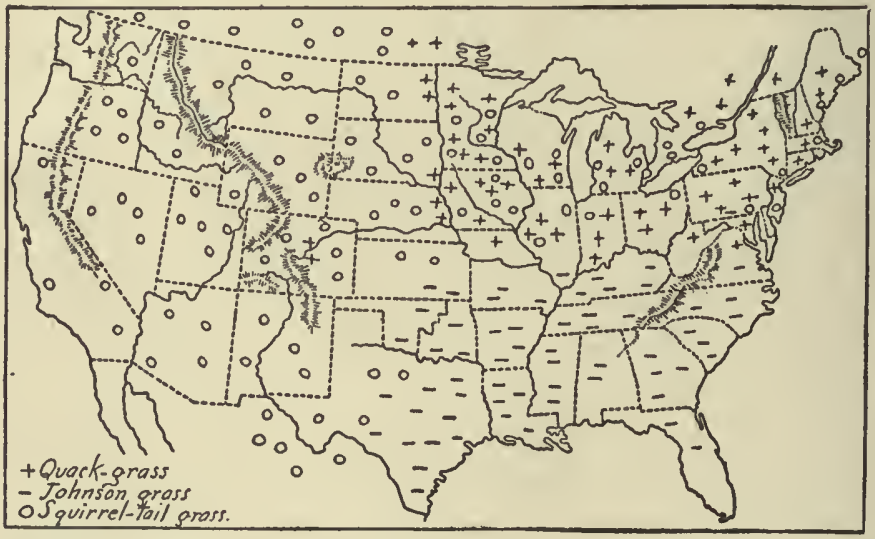

Fig. 34. Distribution of some weeds, quack grass, etc. (C. M. King.)

the northern states. Purslane was cultivated as early as 1672 in Massachusetts, and since then has spread to all portions of the United States. Were it not for some of these records it would be quite impossible to say whether a plant was indigenous or native. We have better records of the appearance of later introductions, like the golden hawkweed, first found in the eastern states, where it has become a troublesome weed and occasionally found now in the western states, even in Iowa. While some 
weeds have spread westward some of our western plants have spread eastward. Generally speaking, the movement of weeds in our own country has been westward, although niggerhead, squirrel-tail, marsh elder, and" sunflower have moved eastward. In Gray's "Manual," sixth edition, the distribution of marsh elder is given as follows: Northwest Wisconsin to Minnesota and Kansas westward. It must, indeed, originally have been quite local in many places in this region. It is only recently that this weed has attracted attention. Another illustration is buffalo bur. In Gray's' "Snyoptical Flora," the distribution is given as "Plains of Nebraska to Texas and Mexico." In Gray's "Manual," sixth edition, the statement is made, "spreading eastward to Illinois and Tennessee." Britton, in his "Manual of Botany," says, "On prairies, South Dakota to Texas and Mexico. Occasionally in waste places as a weed, Ontario to New Hampshire, Massachusetts and New Jersey, adventive from the West." This plant has certainly spread to many different points in the Eastern States.

The Canada thistle was early introduced in the East, but now occurs, according to Dewey, in all of the Northern states and in Canada across the continent. Its distribution shows the lines of tension in its northern extension. The same may be said of the bull thistle, which is as abundant in Montana and Utah as it is in Oregon and Washington. Where new lines of railway are opened in Canada these European immigrants follow.

Few of the southern plants have spread northward. Among these, however, we may cite the horse nettle (Solanum carolinense). The record of sand brier or horse nettle forms an interesting chapter in the migration of perennial plants from one part of the country to another. It is much easier for an annual to become acclimated than a perennial. Throughout the Mississippi valley 
there are tropical plants which have become thoroughly naturalized, as Amaranthus retroflexus, $A$. albus, A. spinosus, Abutilon Theophrasti and Sida spinosa. Within the memory of the present generation Indian mallow has been naturalized in western Wisconsin; Argemone mexicana in a comparatively short time has found its way into Kansas, Iowa and Illinois. Cardiospermum Halicacabum of the southwest is common in Illinois opposite St. Louis.

Of our early weeds reliable information is often wanting, although in some cases the history is well known. Prickly lettuce (Lactuca Scariola) made its appearance in eastern Massachusetts first in 1863 , but is now found in many states of the Union, growing like a native plant. Mention of this weed was made by Professor Arthur in an early catalogue, but it either failed to establish itself or it escaped the notice of botanists. In Europe, we have reliable information concerning the spreading of a number of weeds. Water weed (Elodea canadensis), a most harmless water plant in North America, first appeared in Ireland in 1838 ; in 1846 it was recorded in Scotland; in 1860 it was observed on the continent; in 1862 , it became generally distributed. Dr. Webber thinks that the gradual lessening of this weed in Europe may have been due to some natural enemy.

The water hyacinth (Eichornia crassipes) has become a serious menace to navigation in Florida. This plant, which is a native to South America, has long been cultivated in northern greenhouses. Dr. Webber, who made quite an extensive study of this weed, states that it was probably introduced into the St. John's river about 1890 , about four miles above Palatka, where it was grown in a pond. The pond was cleared and the material thrown into the river and from thence it spread to other streams, having been scattered by boats. It became abundant in I894, having been carried up the Ocklawaha River, from 
whence it was spread to all the lower streams of the St. John.

Squirrel-tail grass was common about the great ıakes, where it was indigenous, but was not common in many parts of Wisconsin in $188_{3}$, although, even then, it was frequently seen in low grounds about Madison, and is now abundant. It was in parts of Iowa in 1865 , and now occurs in every county of the state.

The hawkweed, according to Dr. Jones of Vermon became a weedy plant between 1860 and 1875 . Mr. W. H. L. Truman of Brockport, N. Y., referred to it as spreading from cultivation. It was introduced as a cultivated plant in 1818 . It was recorded in Vermont in 1873 , and, at about the same time, in Rhode Island.

With these annuals, it is only essential that they mature their seed, but with perennials they must not only mature their seed, but the plants must be able to survive the winter. Those who hold that perennials cannot be acclimated will find an exception in Solanum carolinense, Darlington, in his "Flora Cestrica," makes the statement that it was introduced by the late Humphrey Marshall into his botanical garden at Marshalltown. Beck, in I833, gave its distribution as Pennsylvania to Carolina, west to Mississippi. In the second edition of Gray's "Manual," Connecticut is included; it is also included in the fifth edition; and in the "Synoptical Flora" it is said to occur from Connecticut to Illinois and southward. Dr. Eaton, however, writes me that he has not seen it, and there is no record of its occurrence in that state, except the specimens found by Dr. Robbins. That the weed is still spreading in West Virginia is indicated by Millspaugh. In 1852, Brendel found it native in Peoria, Illinois. Solanum carolinense also occurs in Wisconsin.

In recent years, many weeds have been introduced by means of impure seeds. Throughout the state of Iowa, one will find that our clover meadows contain carrot, 
buckhorn, chicory, evening catchfly, dock, bull thistle, sheep sorrel, and many others that might be enumerated and which have come in with impure seeds. These are treated more at length under the head of "How Seeds Are Scattered." 


\section{CHAPTER XI.}

\section{EXTERMINATION OF WEEDS}

Among the most important considerations in connection with the extermination of weeds are prevention of the maturing of seed and the sowing of good seed oniy. In the long run the more expensive clover seed is better than the cheaper grade. Manure should be thoroughly decomposed to prevent the scattering of weed seeds. I found that seeds of various weeds placed in manure that underwent decomposition were destroyed.

Cultivation.- No other method is so good for the extermination of weeds as cultivation by keeping the fields clean. With ordinary cultivation the annual weeds are readily destroyed. Where the field is very weedy it may be necessary with perennial weeds to summer fallow, and perhaps we may as well give the methods for destroying a few of the perennial weeds. Take quack grass as an illustration, which is the most injurious weed in the state of Iowa, especially in the northern part of the state.

The difficulty in exterminating weeds is due, in many cases, to the prolonged vitality which many weed seeds possess. Indian mallow, shoofly and other members of the mallow family retain their vitality for years. The seeds of many Leguminosae display the same characteristic. Cases may be cited where fields which had been in meadow for years upon being plowed soon abounded in the greater ragweed, in the grain crop. Such weed seeds may have been scattered by freshets, but the coats of the involucre being very hard the seeds were thus able to delay germinating. In the case of the cocklebur, one "seed" germinates one year and the other the next. When the seeds' coats are hard the seeds may retain 
their vitality for long periods. Manure should not be applied on fields until it has been thoroughly composted, and thus the weed seeds contained in it thoroughly destroyed. This is not the usual practice. When fresh manure is spread on the field, the straw should be reasonably clean. Clean seed should be sown.

In the general treatment of weeds, in order to exterminate them, it is first always important to prevent the formation of seed and secondly to prevent the formation of roots. This subject will be discussed under the following heads: (I) Rotation of crops. (2) Treatment of annual weeds. (3) Treatment for biennials. (4) Treatment for perennials. (5) Treatment for special weeds : $a$, in meadow and pasture; $b$, in grain fields; $b a$, among small grains; $b b$, in corn fields; $c$, in gardens; $d$, on roadsides, in yards; $f$, lawns; $g$, summer fallow. (6) Treatment with herbicides. (7) Fungi destructive to weeds.

Rotation of Crops.-It is a well-known fact that a soil long cultivated with the same crop is generally not as remunerative as where rotation of crops prevails. A piece of land grown continually in wheat, oats, or flax will leave the field full of foul weed seeds. The continuous cropping of flax and oats in the northwestern states has left the fields so full of mustard that in some places there is almost as much mustard as oats or flax. The continuous cropping with corn, combined with poor cultivation, has left many fields in southern Iowa and northern Missouri full of cocklebur. The continuous cropping with oats has often resulted in large quantities of wild oats growing with the tame. The continuous use of the pasture without renewal has caused blue vervain to become a bad weed. Professor Spillman gives the following as a definite suitable rotation: When sod is plowed, the land is planted in corn, then wheat is sown and grass follows. A freshly broken sod, brought into good condition will 
be much easier to take care of than a piece of wheat or oats ground. It will contain a far smaller number of weeds, and consequently fewer weed seeds. Corn in such ground is usually quite clean by the time it is "laid by," and there is less chance for weed seeds to mature than in a "small grain" field. This method of cropping insures a smaller number of weed seeds when this corn field is placed in small grain the following year. After the small grain is removed it is always advisable to plow as soon as possible and then harrow in order to expose the roots of weeds already in the soil. If the small-grain crop is followed by clover a crop fairly free from weeds should be produced. It would be better if the clover meadow could be converted into blue grass pasture.

When there is a tendency for weeds to appear, the blue grass should be encouraged to occupy the vacant spaces. In the East, where alfalfa is grown it should be treated in the same way as clover, but Mr. J. E. Wing of Ohio keeps all of his land, so far as possible, in alfalfa. In the West, especially in the Rocky Mountain country, it is far better to retain an alfalfa meadow for a long term of years.

There are some notable illustrations in western Wisconsin, eastern Minnesota and northeastern Iowa, where mustard and wild oats were, at one time, as abundant as in the small grain-growing section of Minnesota and the Dakotas; but by converting the tillable lands largely into pastures and meadows these weeds have ceased to be so troublesome. Small grain fields where rotation has been practiced are almost entirely free from weed seeds. So far as annual weeds are concerned there is no better way of treating them than by a systematic rotation of crops.

Treatment of Annual Weeds.-The most important point in connection with annual weeds is to prevent the formation of seeds. Cultivation of a field should be thorough at all times. The best time to kill these annual 
weeds is when they are young. The roots of all seedling plants are 'readily killed by being exposed for a short time to the sun. A field or garden should be plowed and then brought into a good state of tilth by using the harrow. When planted with small grain or any other crop, a little more labor in the spring may mean the saving of much labor later. All of the annual weeds mentioned in the list of most troublesome weeds should be treated in this way. It may be difficult to destroy older plants of purslane, for example, but young seedlings are easily destroyed. Many of the annual weeds may be destroyed with a solution of iron sulphate or copper sulphate.

Treatment for Biennial Weeds.-The biennial weeds are not nearly so numerous in kind as the annual or perennial and are much more readily destroyed than the latter. The bull thistle, burdock and other biennial weeds of this character are readily destroyed by cutting the plants off a few inches below the surface of the ground. A small spade will do this easily. In cutting, it is, of course, essential to cut the root below the buds. The bull thistle produces a mat of leaves close to the ground the first season; by cutting these off, as stated above, the plant will not shoot up the second season.

Treatment of Perennial Weeds.-Perennial weeds are nearly always difficult to destroy, much depending upon the character of the "roots" produced by them. The first and most important consideration is clean cultivation. At no time should leaves be permitted to appear, as these are the organs which make plant food. As an example, nimble will may be cited, which is so common in the Mississippi valley. The "roots" of these plants (there are several different kinds) are clustered. By plowing the field, and running a harrow through it, then later giving it thorough cultivation, the weeds can nearly always be destroyed. They do not persist long in a pasture in competition with blue grass. Dr. C. E. Bessey 
has well emphasized the importance of cultural methods in the extermination of perennial weeds. The horse nettle is quite as difficult to destroy as any of the perennial weeds. Like milkweed, it produces a long root, sometimes three to four feet long and when the root is severed, it produces buds that form new plants. The "smothering" method has proven efficacious. This is probably the most effective and at the same time the least expensive method of removing horse nettle. Rape is probably the most suitable crop to employ for this purpose. If the soil is not already rich, a liberal dressing of barnyard manure should be applied during the winter or spring and the soil should be harrowed or cultivated frequently until the time of seeding, which may be at any time during the months of May or June. This cultivation will prevent weed growth and at the same time will assist in the retention of moisture. If the rape is sown in drills, about two pounds of seed per acre is a sufficient quantity, and three pounds if sown broadcast.

When the crop has attained a rank growth it may be pastured or removed and fed to stock. Where land is lacking in vegetable matter, it is a good practice to plow the crop under when it is properly matured. The latter is not necessary when the object is merely to destroy the nettle, as the rank growth of the crop is very effective in completely smothering the weed.

Other Methods.-Planting to corn or roots is a method much in vogue for the destruction of horse nettle. As in the method described above, the plant should be kept down before seeding time. When the crop appears above ground, the use of the horse and hand hoes should be unsparing. When the welfare of the crop prohibits the use of the horse hoe, the hand hoe should be used at intervals until the crop is removed, and even then it may be necessary to give attention to this pest. There is no question about this mode of treatment being effective if properly 
carried out, but failure often results from negligence during the latter part of the season. Of course, it is possible that seeds may be lying dormant in the soil and make their appearance the next season, but it is taken for granted that all measures to eradicate the plant by preventing the production of seed have been used.

Treatment for Meadows.- The treatment of a meadow necessarily varies according to conditions. If the pasture is very weedy, it is probably due, partly, to overgrazing. In such cases, some of the stock should be removed and the perennial grasses allowed a chance to form a turf. Mowing the weeds once or twice before the seeds are allowed to mature is an excellent plan. Sheep are better weed exterminators than most other animals and will keep many of the noxious weeds down. For some weeds such as buckhorn and wild carrot it may be wise to practice rotation.

Treatment for Grain Fields.-In order that fields be free from weeds, the first essential is to sow clean seed, which will do much to aid in keeping weeds down. Early fall plowing will do much to remove many annual weeds. The common custom in a corn country of sowing wheat on corn stubble, where disking alone is resorted to, is poor practice, because in many cases the corn fields are not clean. It is far better to cut the corn, shock it and then plow. It is not a bad practice in the fall to turn sheep into a corn field to pick out the weeds.

Treatment for Corn Fields.-There is no danger of introducing bad weeds into the soil with seed corn; but bad perennials are scattered by the cultivator, such being the case with quack grass and Johnson grass. Cultivation aggravates the trouble. Where these weeds occur the hoe must follow the cultivator, and this must be kept up during the entire season, hoeing at least once a week. The ground of a corn field should be clean and should be plowed in the fall and again in the spring, being both 
disked and harrowed. It will then be ready to be planted in corn, which should be followed by harrowing, and cultivation should then begin as soon as possible. This will keep all of the annual weeds down. By the time the corn is ready to be put by, there will be no weeds. Where quack grass occurs, plowing in the fall should be at least nine or ten inches deep.

Treatment for Garden Weeds.-The annual weeds are easily destroyed by giving thorough cultivation; the perennial are less readily subdued. In the case of nimble will, the "roots" should be exposed to the sun, being killed after a few days of drying. Where quack grass appears, the roots should be removed and the ground given shallow cultivation. As roots appear they should be cut off each week until the close of the season. Occasionally this method is not sufficient; then it is advisable to cover the patch with tarred paper allowing it to remain for six months.

Weeds of the Roadsides.-Many of these weeds are annuals, and by mowing them at the beginning of the flowering season, may be destroyed. If they reappear they should be mowed again, and, if possible, clover and grass should be induced to grow in place of the weeds, where they will undoubtedly thrive. The roadsides on the clay soil of northeastern Iowa contain comparatively few weeds, clover and blue grass occupying the vacant places. The same conditions may be brought about in many other sections of the country. Some states, notably Iowa, have passed a law that roadside weeds must be cut early in the summer, but the law is often violated.

Treatment for Weeds in Yards.-These weeds in most cases are annuals and can easily be destroyed by cutting them off at the time of flowering. Generally, this will suffice. In many cases the seeds are allowed to mature. This should be prevented. Use iron sulphate as a spray.

Summer Fallow.-The summer fallow is much em- 
ployed to destroy noxious weeds, especially where 1 is difficult to remove them by ordinary cultivation. In the summer fallow the annual weeds will spring up and soon cover the ground. These weeds should be turned under when green, as they will add much to the fertility of the soil. In the case of perennial weeds, it may be necessary to cultivate the field frequently every week, especially in the case of quack grass and horse nettle. It is certain that the summer fallow, with frequent cultivation, will do much to destroy quack grass.

Destruction of Weeds by Chemicals or Herbicides.For many years, both in this country and in Europe, experiments have been made with various substances looking toward the destruction of fungi by chemical means. For nearly a century, blue vitriol has been used to destroy the spores of smut. It has been known also for many years that certain chemicals, known as herbicides, are valuable for the destruction of weeds. While certain substances, as copper sulphate, for example, are generally recommended for the destruction of fungi, some persons hold that copper, in some of its forms, is injurious to vegetation.

However this may be, it is also true that copper sulphate in various forms, chiefly in the preparation known as bordeaux mixture, is one of the most valuable means that the horticulturist has for combating fungous diseases. It is likewise true that copper sulphate, in some of its forms, when used to kill the smut spores in corn, is more or less injurious to the young plantlet. The injury here retards somewhat the development of the oat or wheat plant, but the plant recovers completely later.

The discovery was made in France about a dozen years ago that copper sulphate destroyed charlock and mustard. The discovery was accidental, but it led $\cdot \mathrm{M}$. Aime Girard to experiment with various materials in the same line, and since then many experiments with these 
herbicides have been made, both in this country and in Europe.

The substances experimented with by M. Girard, were common salt $(\mathrm{NaCl})$, copper sulphate or blue vitriol $\left(\mathrm{CuSO}_{4}\right)$, iron sulphate $\left(\mathrm{FeSO}_{4}\right)$, sulphuric acid $\left(\mathrm{H}_{2} \mathrm{SO}_{4}\right)$, sodium nitrate $\left(\mathrm{NaNO}_{3}\right)$, ammonium sulphate, $\left(\mathrm{NH}_{4}\right)_{2} \mathrm{SO}_{4}$, potassium sulphide $\left(\mathrm{K}_{2} \mathrm{~S}\right)$, basic slag (a mixture of lime phosphate, lime sulphate and some other substances), carbolic acid $\left(\mathrm{C}_{6} \mathrm{H}_{5} \mathrm{OH}\right)$, slaked lime, and formaldehyde $\left(\mathrm{CH}_{2} \mathrm{O}\right)$.

Very successful results from the treatment of weeds have been reported by Sommerville, Foulkes, and Voelcker of England, Steglich, Aderhold, Frank, and Heinrich of Germany, and by Girard, Dusserre, Marre, and Heuse of France. In this country, some of the earliest experiments were made in 1897 by Jones and his co-workers, Crton, Morse, and Edson, of the Vermont Agricultural Experiment Station by destroying the hawkweed with common salt. In I898, an experiment was reported with salt, copper sulphate, kerosene, potassium sulphide, white arsenate of soda, and commercial weed killers.

In 1900, Professor Bolley reported the successful treatment of weeds with copper sulphate and later reported the treatment with equal success of Canada thistle, dandelion, mustard, false flax, worm-seed mustard, corn cockle, shepherd's purse, bindweed, pigweed, kinghead, red river-weed, ragweed, and cocklebur. The rose was not destroyed and leaves of wheat were injured but slightly. The chemicals used were common salt, iron sulphate, and corrosive sublimate. I reported on the effect of carbolic acid on the Canada thistle and of copper sulphate and bordeaux mixture upon two types of mustard. Professor Shutt and Fletcher of the Canada station also reported the successful killing of weeds by herbicides. Wilson of Minnesota reported on the use of some chemicals with quack grass and found kerosene ineffectual; salt, how- 
ever, being effectual where a sufficient quantity was used. Stone of Cornell University Experiment Station also reported on the successful treatment of certain weeds with copper sulphate, and Moore of Wisconsin reported on the successful treatment of mustard with iron sulphate.

The above gives an idea of the activity along this line. Perhaps we can do no better than to discuss the different chemicals and their action on weeds separately.

Copper Sulphate.-This well-known fungicide has been found effective for the destruction of certain weeds. At the Iowa station it has been found that it destroyed the leaves of burdock, prickly lettuce, common mustard, prostrate pigweed, and goosefoot. It was ineffectual on the leaves of morning glory, and was only slightly effectual on knotgrass. It did not seriously affect the leaves of the foxtails. The copper sulphate, to be effectual, should be applied according to the following formula: $12 \mathrm{lbs}$. copper sulphate to 52 gallons of water. Spraying should be done in dry weather If it rains immediately after spraying, the spraying should be repeated. Prof. Bolley finds this strength solution is as effective for weeds as 100 pounds of iron sulphate. Professor Howitt of Guelph tells me it is not as effective on mustard as iron sulphate.

Sodium Chlorid.--Salt with some of the weeds experimented on by Bolley gave good results, using it at the rate of one-third barrel for fifty-two gallons of water. It is certain, however, that in many of the perennial weeds this will not be effective. It is certainly not effective in the case of the Canada thistle, quack grass, morning glory and milkweed. Salt has been repeatedly recommended for Canada thistle, but it is only efficacious where large quantities are used and where cattle are allowed to tramp around or utilize the salt thrown around the roots.

Salt has long been recommended to exterminate certain weeds, but Professor Jones of Vermont has shown that while an application of salt may have killed some weeds 
and benefited the grass it also killed the clover, the reason for this destruction being due to the power of the salt to draw the moisture from the plant. It was found that dry salt killed greater quantities of grass than when wet.

Prof. L. R. Jones and A. W. Edson in some experiments made in I900, concluded that common salt was less efficacious for miscellaneous weed killing than arsenate of sodium, carbolic acid or sulphuric acid, but is the best chemical for the destruction of orange hawkweed.

We found that dry salt in concentrated form will kill quack grass when applied at the rate of about 600 barrels per acre, but close to the edges of the patch, quack grass, treated thus, sprouted out as before. A much smaller quantity than this might be used, but even in considerably less amounts the salt renders the soil unfit for the growth of agricultural crops, and cannot, therefore, be recommended as a weed exterminator, especially for quack grass. Professor Bolley has found salt effective against kinghead and mustard at the rate of one-third barrel of salt to 52 gallons of water.

Carbolic Acid.--This well-known germicide has also been used to kill weeds. Jones found it to be very quick in action, but observed that it does not penetrate into the soil deeply enough to kill all the root, hence the treated plants invariably recovered.

An experiment was made with carbolic acid on quack grass, using the acid at the rate of $2 \frac{1}{4}$ barrels to the acre, two applications being made, one on October Ioth, and a second on October 26th. The growth of the quack grass had been very rank and vigorous and while it was temporarily checked by the carbolic acid, the roots were not destroyed. Therefore, we cannot recommend the use of carbolic acid for treating quack grass. Other weeds, especially annuals, were affected in a similar manner, but did not recover as the perennial weeds did. 
We may note that carbolic acid was found destructive to pigweed, smartweed, and pigeon grass. The amount of material used would make it so expensive that its use cannot be recommended to kill quack grass or other weeds mentioned in the above list.

An experiment was made at the Iowa station with the Canada thistle, using the carbolic acid at the rate of one part of acid to four parts of water, the solution being thoroughly agitated in order to make a good mixture. At first an ordinary garden sprinkler was used, but this method was found to be expensive and not effective, the tops alone being killed. In another experiment a small mechanic's oil can was used and the acid was placed in direct contact with the root, the effect penetrating from eight to ten inches below the surface of the ground, but below this point the roots sprouted out again in many instances. This method was not considered entirely effective for the destruction of Canada thistle.

Sulphuric Acid.-This has also been recommended as an herbicide. Professor Jones used it at the rate of one part to forty parts of water, applying at the rate of forty gallons to the square rod. It did not kill the weeds, especially the roots, presumably because it formed an insoluble compound. Where the fluid came in contact with the plants they were killed, but they soon recovered, producing new shoots.

Slaked Lime.-Slaked lime has been recommended for the extermination of certain classes of weeds, the lime being spread broadcast over the weeds; however, this has not proven a very effective remedy. In an experiment with lime at the rate of 484 barrels per acre, it was not effective with quack grass or morning glory, milkweed, foxtail, or other weedy grasses. While it did. to some extent, decrease the number of quack grass plants coming out, it did not eradicate them. The same may be said of morning glory and milkweed. 
Formaldehyde.-Formaldehyde, although an excellent germicide, has been recommended for the extermination of weeds, but it is less effective than carbolic acid. In 1907 an experiment was conducted with formaldehyde, using 4 per cent formalin at the rate of $23-4$ barrels per acre. The plants experimented with were quack grass, pigweed, foxtail, and lamb's quarter. While the plants were injured somewhat by the treatment, the annuals more than the perennials, soon after the treatment they became as vigorous as ever.

Corrosive Sublimate.-This powerful disinfectant has been used for the destruction of potato scab and to some extent for the destruction of the spores of fungi. Professor Bolley has found it successful in the treatment of potato scab when used in the following proportions: $21 / 2 \mathrm{oz}$. corrosive sublimate to 15 gallons of water. It is an excellent germicide and antiseptic, but its use as an herbicide cannot be recommended because of the great danger involved from the poisonous character of the chemical.

Sodium Arsenite.-Bolley finds this a valuable spray when used at the rate of $\mathrm{I}^{\mathrm{T}} / 2 \mathrm{lbs}$. to $5^{2}$ gallons of water. Professor Bolley recommends the use of sodium arsenite only where weeds grow in clumps, like the Canada thistle, burdock, and other weeds with persistent underground stems. In such cases the solution can be applied by hand, or if applied with a machine it can be done without regard to the injury of the crop. He considers this the best weed killer on the market. The product on the market frequently contains sodium arsenate, which is very destructive to grains. The arsenical solutions are poisonous and must be used with caution.

Sodium Arsenate.-Sodium arsenate has proven very successful in the extermination of some weeds. Jones and Orton, Edson and Jones, reported it as satisfactory when used in the proportion of one pound of arsenate to 
eight gallons of water. This is also a poison. Use with caution.

Iron Sulphate.-For a number of years experiments have been conducted by a number of experiment stations with reference to the extermination of weeds by this chemical. It has been found at the Iowa Experiment Station that a number of weeds like dandelion, dooryard knotgrass, purslane, yarrow, sorrel, large ragweed, hedge mustard, sour dock, smartweed, mustard, velvet leaf, small ragweed, lamb's quarter, pepper grass, sow thistle, bull thistle, wild carrot, pigweed, shepherd's purse, and spurge can be destroyed by this substance. Bolley finds that it is not effective on pennycress and hares' ear mustard. The grasses are resistant. This substance should be used at the rate of IOO pounds to a barrel of ziater. A dust spray has also been used; it is effective when there is sufficient dew on the plants.

In order to make the spraying effective, however, the application should be made sometime before the mustard or other weeds are in bloom. It is advisable to begin spraying in a grain field when the mustard is from 6 to 12 inches in height. Bolley puts it third to fifth leaf. The siray should be evenly spread over the leaves on a quiet day with no rain for two or three days. Damp weather is effective if sunshine follows. It is better to use a large machine having a capacity of 160 gallons, and if the ground is not too soft two horses can pull the machine readily. The machine should have wide tires. The trouble, as Bolley well says, is because nozzles and machines are not efficient.

The cost of spraying is approximately $\$ 1.25$ per acre and the iron sulphate can be had approximately from $\$ 1.00$ to $\$$ I.I 5 per Ioo pounds in the northern Mississippi valley.

Professor Selby briefly sums up the matter of spraying, as follows: 
"Weed sprays, when properly adapted, should be available for the destruction of the larger portion of our pasture and grain field infesting weeds, when the methods are rightly and economically developed. It would certainly be a travesty on our methods of culture to expect to substitute weed sprays for culture in the growing crop, such as in corn fields and the like."

Lawn Spraying.- -It is desirable to spray a lawn for dandelion, or chickweed; for this purpose a hand sprayer with a Vermorel type of nozzle can be used. I am of the opinion that this spray will be very valuable for lawns and parks. Professor Bolley, who originated the idea to use this substance for lawns, recommends two pounds to the gallon of water. We have found that iron sulphate will do effective work in killing dandelions when a much weaker solution is used, namely, one pound to a gallon of water. This solution should be applied when the dandelion begins to bloom or later, a few days after the lawn has been mowed. It is best to spray on a bright day. A dew will help, perhaps, because the iron sulphate can enter the stomata. Many other weeds of the lawn can be treated in the same way. Spraying should find general application. It should be borne in mind, however, that this substance will not destroy crab grass, foxtails or other weedy grasses and that it is injurious to clovers.

Meadows and Pastures.-Iron sulphate spray can be used for many types of weeds like the ragweed in pastures, dandelion, etc., but not where clover is abundant.

Grain Fields.-Iron sulphate should certainly be used in the grain fields; by its judicious use a larger grain crop can be produced and such weeds as mustard and kinghead can be eliminated. Manufacturers should introduce better machinery.

Precautions.-The iron sulphate should be of the granulated form. The solution should not stand overnight; it should be made up in wooden barrels and then placed 
in brass tanks. Use a hand sprayer for patches; in the field a large sprayer with nozzle to spray a fine mist. Spray in bright sunshiny weather, at least not to be followed by rain for a few days. It is best to have the spray followed by a dew. This is true in particular of the dust spray.

It should be remembered in this connection that spraying cannot be done indiscriminately to all kinds of plants. It will not do to spray a clover meadow, since the iron sulphate is quite as injurious to the clover as to the weeds, nor is it advisable to use the sprayer in a corn field, because many of the common weeds, like the foxtail, crab grass, and pigeon grass, cannot be killed by this spray. But it is certain that the iron sulphate has a wide application in grain fields.

Mr. R. I. Anthony, who has had some experience in spraying, notes some of the conditions which may cause failure or success, as follows:

"Spraying for the eradication of weeds started in Europe-in France and Germany. These two countries possess a climate very different from anything I know in this country. When the procedure was studied a set of rules for guidance quickly found place and one of these was that the spraying should be carried on only on bright, still days.

"In my work from time to time I have met with failure and have as often been puzzled to discover why. On collating the work it is clearly evident that the weather conditions play a great part. French weed in certain stages of growth is completely destroyed by the sulphate of iron spray-when the day is overcast and the relative humidity high. On the contrary, when the day is bright, hot, and the humidity low, the plants are resistant. The same is true of mustard in a less degree.

"Work at Warren this year has so far been a failure, with atmospheric conditions as follows: Bright skies, low 
relative humidity, high temperature, high wind and NO dew.

"At Hunter the work started off in the same way as at Warren, but the timely appearance of dew turned the scale and we succeeded where failure seemed certain.

"Here are the observations: White incrustation appeared on sprayed leaves in three to five minutes, and in some instances white pellicles of sulphate could be seen scudding along the ground. At the end of twenty-four hours white incrustation undiminished and weeds showing no signs of distress. But let the dew fall and the white incrustation disappears like magic and the plants show signs of mortal injury, and in a few hours small plants shrink to bunches of shapeless tinder and large plants droop and brown and shrivel."

Fungi Destructive to Weeds.-In various parts of the world certain fungi are known to be quite destructive to weeds. In the East a rust (Puccinia suaveolens) destroys large quantities of Canada thistle. In other places extensive patches of foxtail are exterminated by the downy mildew of the foxtail (Sclerospora graminicola). Foxtail smut (Ustilago neglecta) destroys a great deal of the seed of this weed. Related smuts, as quack grass smut and one found on stink grass, are also very destructive to weedy grasses. The spot disease of crab grass (Pyricularia gricea) is very destructive to crab grass; so is the spot disease of smartweed (Septoria Polygonorum). Many other fungi might be named in this list. There is no doubt that these fungi are important factors in the destruction of weeds. 


\section{TREATMENT FOR SPECIAL WEEDS}

Quack Grass.-Quack grass is one of the most persistent of the perennial weeds in the state of Iowa and the North. The roots of quack grass are shallow, the vast majority occurring within less than six inches of the surface of the ground. The following methods have been suggested for its extermination:

The Crop Method.-The land is brought into as good a state of tilth as possible and sown thickly with millet, buckwheat, sorghum, or rape. This method does not destroy the roots of quack grass. It does, however, reduce their vitality to such an extent that they are not as vigorous after the removal of millet or sorghum. Then the field should be given a shallow plowing and the roots exposed to the sun. This cannot usually be done in the state of Iowa until the middle or latter part of September. In nearly every season we have very dry weather in October, and after harrowing two or three times most of the roots will be killed by drying.

A second method, which has been followed successfully by some of the German farmers in northern Iowa, is this: To plow the field, harrow, and remove and burn as many of the quack grass roots as can be seen. Then give clean culture throughout the entire season. By digging up the roots with a spade or fork and giving clean culture, hoeing, if necessary, quack grass can be removed. This has been done, not only in our own experiments, but many farmers have tried the same, successfully. It is a rather expensive process, however.

Summer Fallow.-The summer fallow method has been tried frequently in northern Iowa. The land is 
plowed in the spring, disked, and kept clean by harrowing at least once each week during the entire season. Several fields so treated have been investigated by the writer and show no quack grass, but there is a loss of an entire crop.

Small Grain and Cultivation.-Inasmuch as rotations of corn, oats, clover, and pasture are common in the state of Iowa, and since corn is one of the most important crops, it is a question how to proceed to destroy quack grass under these conditions. Experience has shown that quack grass spreads less frequently in a pasture crop or an oats crop than it does in corn. If the field is sown with oats it should be given a shallow plowing as soon as the crop is removed, and harrowed at least once a week during the late summer and fall. This will destroy much of the quack grass by the end of the season. The field can be put into corn the following year.

Pasture.-Many farmers have called attention to the fact, which many of us have observed before, that quack grass does not spread very rapidly in a pasture, and that the roots are small and more superficial than in cultivated corn or a cultivated field.

Professor Spillman, who has taken up this question, states as follows:

"Quack grass, which is as common in many parts of New England as Kentucky blue grass is in Kentucky, is now spreading over a great part of the middle west. ... You may be interested in knowing the methods which are common on the heavier types of soil in England for dealing with quack grass, or, as they call it, 'Couch' grass. In the old country a meadow is quickly taken by quack grass, and when this is plowed up and put in rotation the following method is used:

"First, the sod is plowed, then it is harrowed two or three times to bring the quack grass root stocks to the surface, then a chain drag is run over the land to roll the rootstocks up, after which wagons with hay frames 
are brought on and the roots are removed by hand. Then the land is plowed again and the same process gone over with. After this has been done from three to five times the land is practically free from the rootstocks, and the rotation can be run through without serious trouble from quack grass."

Mr. J. S. Cates, of the office of Farm Management, has made a careful study of quack grass for some years past, and has developed a very much simpler and less expensive method than the above, a method, however, which is not applicable to all situations. Mr. Cates' method is based on the following principles:

"If the quack grass sod be left undisturbed, as would be the case in a meadow or pasture, for two years, the grass meanwhile being cut for hay or kept down by pasturing, all of the deep-lying rootstocks decay, and the new ones that form are all within two or two and a half inches of the surface. After this condition has been brought about, if the field is plowed just deep enough to turn up all of the rootstocks, which will usually be two to two and a half inches, the grass is very easy to kill. This plowing should be done in midsummer after haying time. A few harrowings after this shallow plowing completely destroy quack grass unless it happens to be a very wet season, when the roots are kept alive by the moisture.

"It is of the greatest importance not to plow deeper than necessary in this work. If one plows, say four inches deep, then the rootstocks must be harrowed out from the depth or they will take root and grow again. If the plowing is only two inches deep the frequent harrowings keep the rootstocks from connecting with the subsoil until they have completely perished.

"We have found a good many New England farmers who had dropped on to this method of killing quack grass, and they no longer consider it a serious menace."

Deep Plowing.-Another method is to plow the sod at 
least six inches deep. Our experience has shown that quack grass roots do not penetrate through the soil much beyond a depth of four or five inches, very few going beyond six inches. The following season sow with grain. After the grain is removed plow the land and harrow in such a way as to get all the roots on the surface, and repeat the disking and harrowing as often as the grass occurs, once a week if necessary.

The Cover Method.-Covering with tarred paper, manure, or straw is effective when well done. When tarred paper is used the edges should be thoroughly covered with dirt. The grass must remain covered at least six months. If manure is used it must be compact, a foot or more in depth. Straw, which is much looser, must be several feet in thickness.

Professors Eaton and Edson of Vermont report success in the treatment for quack grass, "no matter how seriously infested, by the following procedure: (I) Ridging the rows just before the corn sprouts, using a disc hoe or any other tool which makes a ridge over the row. (2) Cultivating three days later with a five-toothed cultivator, or a heavy two-horse hoe, carrying side hoes, (such as potato-hilling hoes turned backwards), drawing the soil away from the sides of the ridges previously made, so that the subsequent harrowing can more effectively level them. (3) Harrowing or weeding (preferably the former) the same day. (4) Cultivating twice thoroughly, a week or ten days later. (5) Weeding the same day, still further leveling the ridges and improving the soil mulch. (6) Cultivating thoroughly and shallow every week or ten days thereafter, so long as it can be done without injuring the crop, the oftener the better. (7) Hand hoeing in mid-July."

Perennial Sow Thistle.-The perennial sow thistle is one of the most troublesome weeds of eastern Canada and in a few of the northern states. Prof. J. E. 
Howitt suggests that sheep be turned in after harvest; these animals, by close cropping, weaken the underground rootstocks. He suggests, further, that the field be cultivated until about the middle of June; to keep the tops down and weaken the roots, slightly ridge up the land with a double moldboard plow, then sow rape at the rate of one and one-half pounds per acre; cultivate the rape every week until it occupies all of the ground. He considers the rape a most excellent weed exterminator, which might be applied to many perennial weeds.

Canada Thistle.-The Canada thistle can be treated with the sodium arsenite. No other chemicals, so far as our experiments extend, will entirely destroy this weed. Carbolic acid only partially destroys the roots and the plants shoot up again from below the point of injury, but by repeating the process the Canada thistle can ultimately be exterminated. A good method to eradicate the weed is to plow shallow and cultivate frequently during the summer. The roots of the Canada thistle extend deeply down into the soil, hence for this reason deep cultivation will be of no avail. After plowing, the soil should be dragged and the roots exposed to the sun and removed, when possible. It may be necessary to run over the field with a hoe to cut off the stray plants which appear. This method was tried on a patch several years ago and no Canada thistles have since made their appearance in this place. Various crops, such as clover and sorghum, are said to be effective in subduing the thistles.

Of the various chemicals which have been used to exterminate Canada thistles none is more effective than sodium arsenite. It is applied at the rate of one and onehalf pounds to $5^{2}$ gallons of water.

Carbolic acid at the rate of one part to one part water destroys the root where it comes in contact with the mixture, and for a little distance beyond. This is not an effective method, as the roots sprout ont from below. 
In response to circulars of inquiry sent out by the Iowa Experiment Station, the majority of correspondents recommended shallow plowing, disking, and harrowing, and continuing cultivation and hoeing as long as the thistles make their appearance. Some report successful treatment with salt when scattered thickly about the thistles, especially if cattle or sheep are given access to it. Some report success with carbolic acid where it is applied directly to the stem. Tarred paper in a few instances gave success, as did also the method where the thistle was covered thickly with straw or manure. The depth of covering was not, however, given.

Milkweed.-Milkweed, like the morning-glory, is a deep-rooted perennial, and where abundant in small grain fields it is rather difficult to remove. The plowing here should always be shallow, as the roots are deep seated and new plants spring up from where the roots are cut off. The plowing should be followed by disking and harrowing to expose as many of the roots as possible and it should be turned into pasture as soon as possible. It is seldom that milkweed becomes injurious to pastures, as the plants lose their vitality. It is by continuous cropping of one crop that the weed becomes pernicious in its character.

In response to a query sent out one correspondent recommended oats one year, clover one year, corn two years, saying the weed is not troublesome in the pasture after the second year. Some have advocated pulling the weed by hand. This is not practical.

Horse Nettle.-In southern states north to Iowa the horse nettle is one of the most troublesome weeds to deal with. Like morning glory and milkweed, it is a deeprooted perennial. The roots are known to extend into the soil as much as three to four feet. The cultivation here should be shallow. When the weed is common, disk thoroughly and harrow, exposing the roots. When a 
field is covered with it, it is better to summer fallow, then cultivate thoroughly and hoe during the entire season, or sow with oats; plow when harvested; disk and harrow for the remainder of the season. The same method used for Canada thistle may also be applied.

Wild Timothy or Dropseed Grass.-The Iowa station has received many letters complaining about this weed. The character of the "roots" is so different from that of the roots of quack grass and the other perennial weeds that we have mentioned before that it is not difficult to exterminate. The "roots" of this weed and the allied species are more or less clustered. In an experiment conducted to exterminate this weed we found that by giving a shallow plowing of four or five inches, and harrowing to expose the roots to the sun, they were killed, no growth making its appearance during the rest of the season. Of course this is not effective during rainy weather.

Cocklebur.-The cocklebur is a serious menace to cultivated crops in many parts of the United States, more especially in southern Iowa and the South. A large number of queries sent out to farmers in different parts of the state brought many responses. Nearly every correspondent reported the weed. The seed habit of cocklebur differs materially from that of many annual weeds that belong to the same family. The bur has two so-called seeds, one of which has a slightly different position from the other; the seed coat, too, is slightly different in structure and, according to Dr. Crocker, this is the reason for delayed germination. Dr. Arthur, in a study of the same seeds, determined that the opinion generally prevailing, that one seed will germinate one season and the other the following, is essentially correct. We have found in our own work that occasionally both seeds germinate the same season. It is very plain, therefore, that if cocklebur occurs in the soil you cannot hope to destroy more than about one-half of the seeds in one season, and if the same 
field is cultivated with corn the next year, another crop of seedings will come on. How long the seeds will retain their vitality has not been definitely determined. The best method of combating the cocklebur is the rotation of crops and clean culture. When a field is in corn, the field should be thoroughly cultivated and none of the plants allowed to mature seed. If they cannot be caught by the cultivator, it may pay to kill the remaining plants with a hoe, or to pull them by hand. The corn should be followed with winter rye and then oats, using the oats as a nurse crop for clover and timothy. Leave the field in meadow for at least two years and then if possible turn it into pasture. This certainly eradicates the cocklebur, ragweed and many other annual weeds.

Foxtail.-It is not generally recognized, but it is probably true, that more money is spent in the extermination of foxtails than of any other class of weeds we have in the state of Iowa, yet they are all easily destroyed. One of the best and most effective methods of destroying the foxtail is by plowing the small grain field as soon as the grain is removed. If this is not done a large amount of seed is produced. After this plowing in the fall the field should be disked and harrowed in the spring and then planted to corn. The corn should be cultivated as frequently as possible, at least four or five times. This method should prove effective for the destruction of foxtail and pigeon grass.

Squirrel-tail or Wild Barley.-Squirrel-tail or wild barley is a most pernicious weed along road sides and in pastures and meadows; pernicious because it not only prevents the growth of the better grasses, but it is injurious to live stock. As this weed is most common in the pasture, the best way to treat it is to mow the pasture before the grass has matured its seed. Since this weed is an annual, or winter annual, this would effectively dispose of the plant were it not for the fact that the seed is 
blown in from neighboring fields and roadsides. Cultivation will readily destroy the weed and where it is abundant in fields shallow cultivation, followed by the disk and harrow, should be effective.

Mustard.-The first and most important consideration in connection with the extermination of mustard is that the oats or wheat should be freed from mustard seed. Then this grain should be sown on clean fields, preferably fields that have been in pasture or meadow. Nothing has done so much to remove the weeds from the fields of northwestern Iowa as the pasture and meadow. If the grain is sown in a corn field there should have been no mustard the previous season. Having sown the small grain on a clean field, there is always a chance that some of the seeds will retain their vitality in the soil. If much of this mustard should come up it may become necessary to spray it with iron sulphate. Where the mustard is abundant this is a very effective means of destroying the weeds, using the sulphate at the rate of one hundred pounds to a barrel of water.

Indian Mallow or Butter Print.-Much complaint has come to us about Indian mallow or butter print. This weed, which is very common in many parts of the country, is of course readily destroyed by cultivation. The only trouble is that so much of the seed retains its vitality for a considerable length of time, how long has not been definitely determined. The best treatment for this plant is to get the field into meadow or pasture, leaving it in this condition for a number of years and then planting to corn and following the usual rotation.

Morning Glory.-The morning glory, though a troublesome weed in many parts of the North, does not seem to be quite as pernicious in its character as quack grass. In response to the queries sent out it is found that the best treatment that can be given the morning glory is to turn it into pasture. Cattle, sheep and hogs are very effective 
in keeping this weed down. One writer states that by keeping it in pasture four or five years the weed is killed. Mr. Cox, in addition to cultural methods, recommends the use of alfalfa as a weed exterminator. The plowing should be thorough and done as soon as the grain is removed in July or August, but it need not be deep, as the roots extend several feet into the soil and cannot be reached by plowing. Where

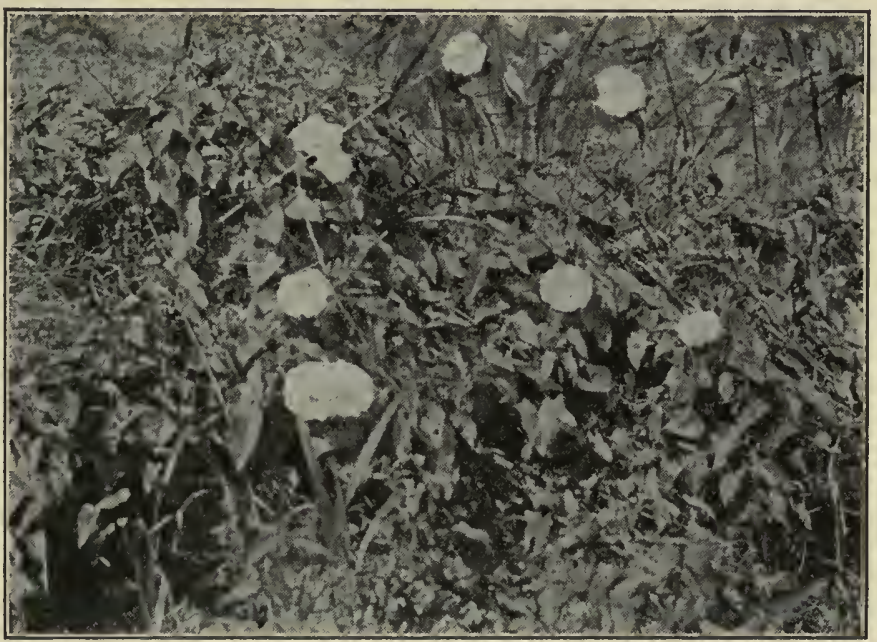

Fig. 34A. Wild morning glory or bindweed (Convolvulus sepium). (Photograph, Charlotte M. King.)

the weed is common the plowing should be followed by disking and harrowing and the roots should be exposed to the sun. One correspondent recommends corn, oats, and pasture. Another recommends millet, sorghum, and buckwheat as effective in the destruction of the weed. When a cornfield contains a considerable amount of the morning glory the cultivation must be frequent and the hoe should follow the cultivation, especially to destroy the plants which make their appearance around the hills. 


\section{CHAP'TER XIII.}

\section{THE MORPHOLOGY OF WEEDS}

The Root.-In the higher plants we are usually able to make out three conspicuous organs, namely: The root, stem and leaf, and at certain stages of development, a fourth organ, the flower. The root, stem and leaf have

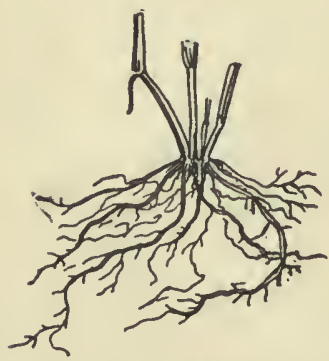

Fig. 35. Fibrous root of crab grass.

to do with the nutrition of the plant and the flower with its reproduction. In our study of a type plant, let us begin with the root. Roots naturally occur in the ground; they fix the plant in the soil and absorb water that holds in solution certain mineral constituents. The root increases in length from a point just back of the tip, growth taking place at this point. The tip of the root is called the root-cap and is continually wearing away, while new cells are as constantly being added from the growing point. Not far from the tip also are the root hairs, which absorb moisture from the soil. These become covered with particles of sand, because the cell walls are mucilaginous.

There are four types of roots, classified according to duration: Annual, winter annual, biennial and perennial. In plants with annual roots, the seeds germinate, the plants produce flowers and seeds the same season and then die.

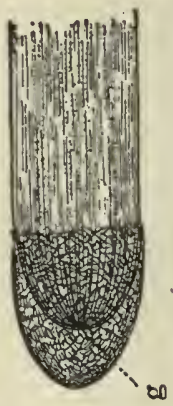

Fig. 36. Root. g, showing root cap. (Leavitt.) 
The following are illustrations of this type: Awned brome grass, black medick, bracted plantain, brome grass, bur clover, buffalo bur, cheeses, chess, cockle, cocklebur, common sunflower, cowherb, dooryard knotweed, dog fennel, fetid marigold, Fuller's teasel, goosefoot, great ragweed, green foxtail, hairy brome grass, hedge mustard, horseweed, Jimson weed, marsh elder, Mexican fireweed, mustard, pepper grass, pigeon grass, pigweed, prairie bitterweed, prickly lettuce, purslane, Rocky Mountain bee plant, Russian thistle, small ragweed, smartweed, squirrel-tail grass, tumbling mustard, velvet weed, vetch, wild barley, wild oats.

The seeds of winter annuals germinate in the fall, the plants live through the winter and in the spring produce flowers and seeds; shepherd's purse, speedwell, winter rye and winter wheat are types of this class. Such plants are more common southward than in the North. Plants which in the North are annuals may become winter annuals in the South.

The seeds of biennials germinate in the spring, producing a growth of short stems and leaves the first season, but no flowers; in the second season the

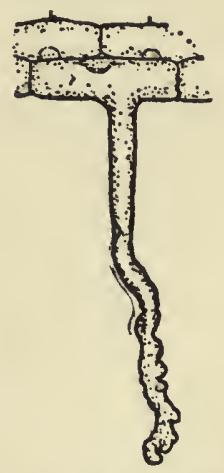

Fig. 37. Root hair. (Leavitt.) stem elongates, produces flowers and seeds. The following weeds are biennial: 'Bull thistle, burdock, mullein, Nelson's thistle, parsnip, and sweet clover. Other representatives: Cultivated beet, cabbage, carrot, and parsnip.

Perennial plants produce roots which continue to live year after year. All of our trees and shrubs and the following weeds are perennial: Blue lettuce, buckhorn or ribgrass, Canada thistle, common nettle, common plantain, cowbane, curled and smooth dock, dandelion, dogbane, gaura, germander, horse nettle, ironweed, milk- 
weed, morning glory, nimble will, northern nut grass, quack grass, tanweed, western nettle, wild liquorice, wild poppy, wild timothy, woolly thistle, yarrow.

Other kinds of roots are the aerial, which are produced in the air, an example of this class being the roots of the poison ivy, the brace roots of Indian corn, trumpet creeper, etc. The brace roots of corn become absorbing organs as soon as they strike the ground. In the poison

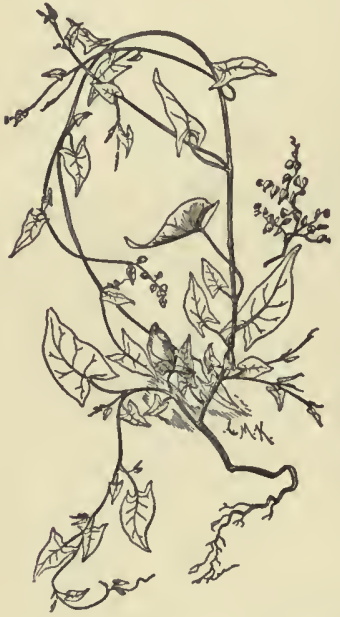

Fig. 38. An annual weed, wild buckwheat (Polygonum Convolvulus). ivy, they assist the plant in climbing, taking the place of tendrils. In one class, including certain orchids, the plants become attached to other plants, but do not take any nourishment from them. These are known as epiphytes. In a third class, the roots are not only attached to other plants, but obtain nourishment from them. These are called parasitic plants, in which group are the clover dodder and green parasites such as mistletoe. Some roots become greatly thickened, such as in the sweet potato, dahlia, carrot and turnip, the upper part of the turnip, however, being really a stem. Roots of this class store food for future use, and are known as fleshy roots. They are conical, as in the carrot; fusiform, as in the dahlia; turnip-shaped, or napiform when like those of the turnip.

The Stem.-The stem occurs in an abbreviated form in the seed; but as we ordinarily see it, it is above the ground. It is spoken of as the ascending axis, and is divided into nodes and internodes, the leaves making their appearance at the nodes. In addition to the stems 
occurring above ground some are underground, which are often merely disguised "stems," like the quack grass stem. Buds are really branches and bear small scales, which are only modified leaves. The bud terminating a branch is called a terminal bud. Fleshy buds are those having fleshy scales. When more than one bud occurs in the axil of the leaf, they are called accessory buds, as in the case of the butternut and honeysuckle. Buds also occur under the petiole of the leaf, as in the sycamore, and are called sub-petiolar buds. Some buds are so concealed that they cannot be seen until growth begins. These are known as latent buds. Adventitious buds are such as develop without any regular order from any part of the stem or from roots. The sweet potato root develops these adventitious buds and many plants such as the plum produce suckers from them.

The stems of grasses, lily, and onion are endogenous; the outside is the epidermis and the bundles are distributed through the mass. The stem of pigweed is exogenous, and consists of pith, wood and bark.

Most plants of our region form a definite annual growth with a ter-

minal bud, hickory and horse chest- Fig. 39. Brace or air nut being examples of these. Some (C. M. King.)

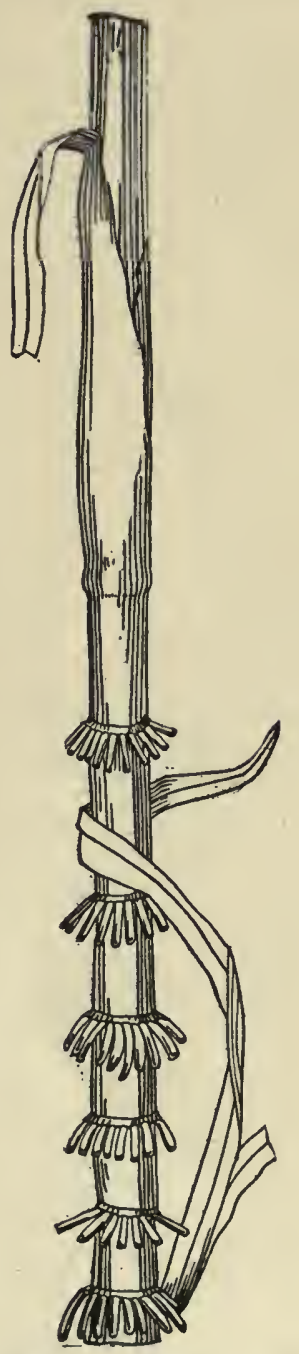


plants, as the grape, grow until killed by frost, whatever buds are not fully developed at that time being killed. This is known as indefinite growth.

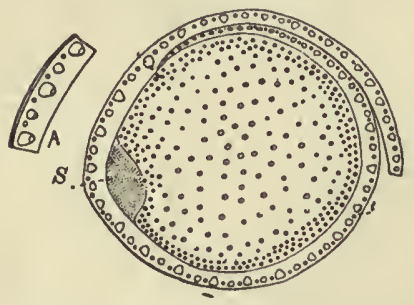

Fig. 40. Cross section of an endogenous stem of corn (Zea Mays). S, node; $A$, sheath of leaf. The small dots, the fibrovascular bundles. (C. M. King.)

scales on the rootstock of quack grass are also modified leaves.

A typical leaf consists of a blade, the stalk or petiole, and a pair of stipules. In some cases the stalk may be wanting and the leaf is said to be sessile, in others the stipule is wanting and in a few the blade is wanting.

The blade is the expanded part of the leaf and is for the purpose of making food. The petiole is the stalk and serves to fix it to the stem. The stipules are a pair of small scales at the base. There is great variation of the different parts of the leaf.

There are two kinds of leaves as to venation. Corn and other stem.

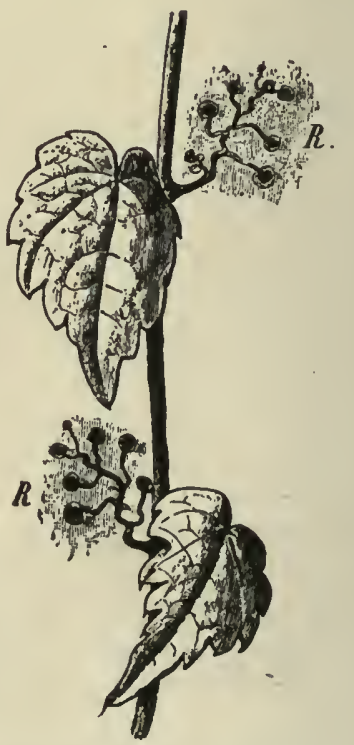

Fig. 4I. $R, R$, tendrils of apanese ivy, modified 
grass leaves are parallel veined, the leaf of the canna has a similar venation. The veins or lines run parallel with

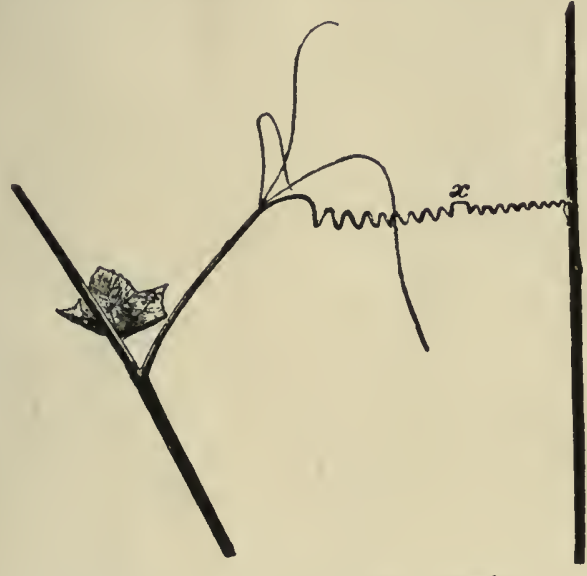

Fig. 42. $x$, tendril of star cucumber.

each other from the base to the end of the leaf. Plants with such venation have a single seed leaf or cotyledon.

In netted-veined leaves the veins run together or anastomose, forming a network, as in the maple, оак, and potato; all of our trees have netted-veined leaves. There are two types of these, the palmately veined, when the veins start from a number of ribs, as in the grape and maple, or pinnately veined, where one rib runs through the leaf from the base to the tip, as in milkweed.

Leaves are divided into simple and compound. In a simple leaf, like the maple, there is a single stalk and a blade. In compound leaves there are several leaflets, each

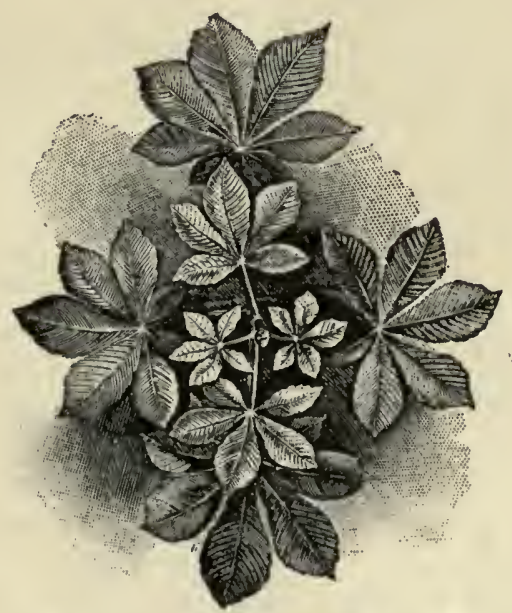

Fig. 43. Palmately netted-veined, compound leaf of horse chestnut. 
usually with its own stalklet, as in the rose. Compound leaves are of two kinds: pinnately compound, in which the leaflets are arranged on the sides of a main stalk, as in rose and ash; and palmately compound leaves, in which the leaflets are borne on the end of a

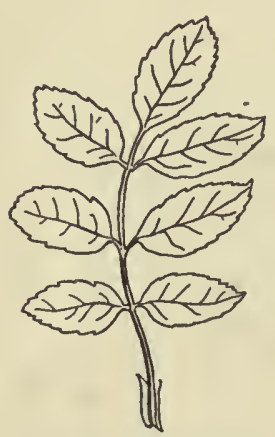

Fig. 44. Pinnately netted-reined leaf of rose. (Ada Hayden.) leaf stalk, as in the horse-chestnut and Virginia creeper. Clover has a trifoliate compound leaf, $e$. $g$., a leaf with three leaflets. Some leaves have two leaflets, these are bifoliate. Some leaves, like the honey locust, are simply pinnate, but occasionally on young shoots they are divided again; these, then, are twice pinnate. The palmately compound leaves of meadow rue are in threes or ternately compound, or four times compound. When a leaf is twice compound it is biternate.

There are many different forms of leaves, the more important being as follows: Linear, a narrow leaf much longer than broad, like blue grass; lanceolate, a leaf which is longer than broad, tapering toward the apex, outline lance-shaped; oblong, when longer than broad; elliptical, like an oblong leaf, but the ends of the same width; ovate, longer than wide, the base wider than the end, like a hen's egg in outline; orbicular, circular in outline; oblanceolate, like a lanceolate leaf, but the apex wider than the base; spatulate, shaped like a spatula, apex rounded; obovate, like an ovate leaf, but the apex wider than base; cuneate,

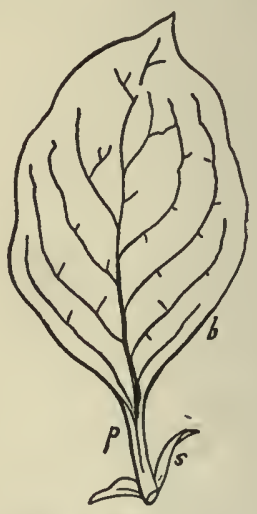

Fig. 45. Parts of a leaf; $s$, stipules; b. petiole; b, blade. 
a wedge-shaped leaf; cordate, leaf with a wide and rounded base, forming a notch where the petiole is attached; reniform or kidney-shaped leaf, like the leaf of wild ginger; auriculate, leaf with a pair of small blunt pro-
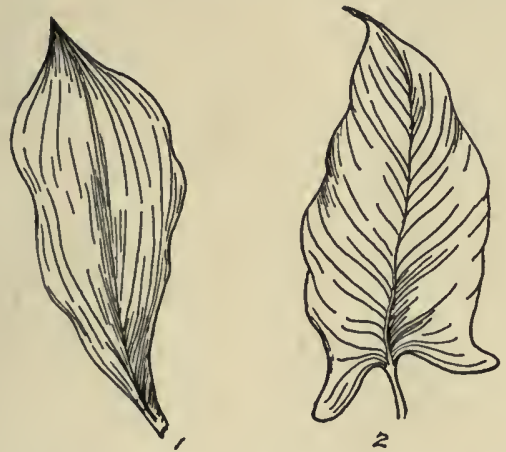

Fig. 46. Two types of parallel-veined leaves.

rather abruptly; obtuse, where the leaf has a blunt or rounded apex; mucronate, where the apex of the leaf is tipped with a small and short point; truncate, with the end as if cut off square; retuse, where the summit of the leaf has a small notch; emarginate, with a decided

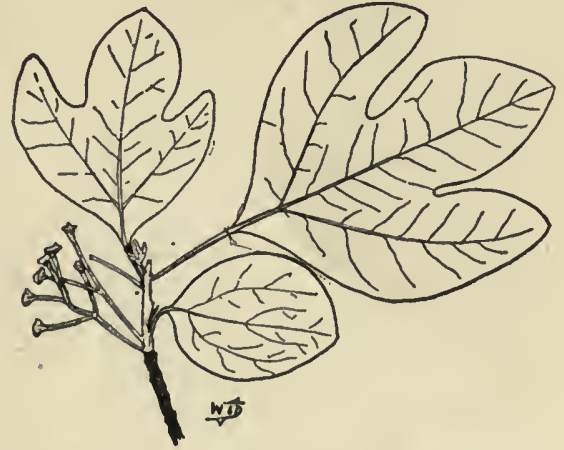

Fig. 47. Lobed leaf of sassafras. (Dudgeon.) sagittate, like an auriculate, but the projections are sharp, as in sagittaria; hastate, like the last, but with lobes pointing outward; peltate, the petiole attached to the lower surface, like the mandrake; acuminate, the apex of leaf prolonged into a tapering point; acute, where the leaf ends in a sharp point jections at the base; notch; obcordate, the reverse of cordate, the upper end larger, like the leaf of white clover; cuspidate, leaf with a 
sharp and rigid point; aristate, when the end is tipped with a bristle point; entire, when the leaf is entirely filled

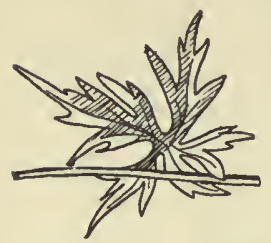

Fig. 48. Lobed leaf of aconite. (Ada Hayden.)

out; serrate, when the margin is cut with sharp teeth; dentate, when the teeth point outward; crenate, leaf with rounded teeth; rcpand, when the margin of the leaf forms a wavy line; incised, when the margin is cut into sharp, deep, and irregular teeth; lobed, when the leaf is deeply cut. It is generally said to be lobed where the divisions do not extend more than half way between the margin and the midrib, the divisions being more or less rounded; cleft, where the divisions extend more than half
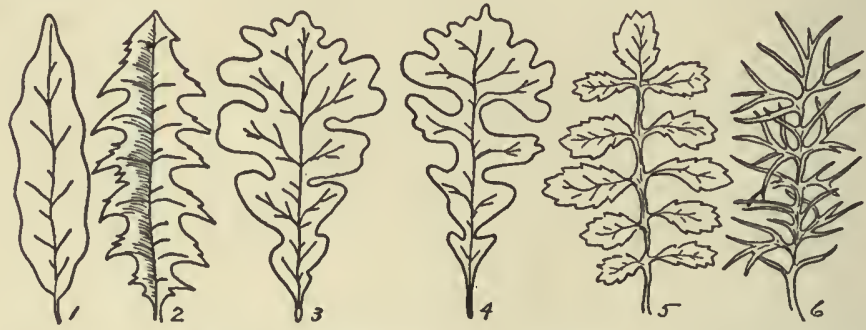

Fig. 49. Leaves of various types: 1 , undulate; 2 , thistle leaf with acute lobes; 3 , lobed leaf of oak; 4 , lyrate; 5 , pinnately divided leaf; 6 , pinnatisect.

way and are sharp; parted, where the divisions extend deeper, but do not reach the middle; divided, where the divisions extend nearly to the midrib. A leaf may be pinnately lobed or palmately lobed; palmately cleft or pinnately cleft, etc.

Some leaves, like those of pea and many other plants of the same order, are provided with a slender filiform body called a

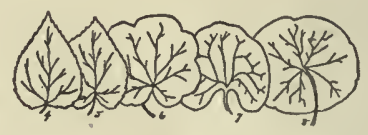

Fig. 50. Radiate-veined leaves : 4,5 , cordate; 6,7 , kidney; 8 , peltate. 


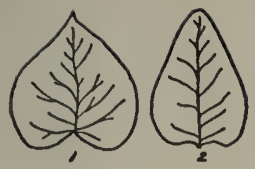

Fig. 51. 1, cordate leaf; 2 , ovate leaf.
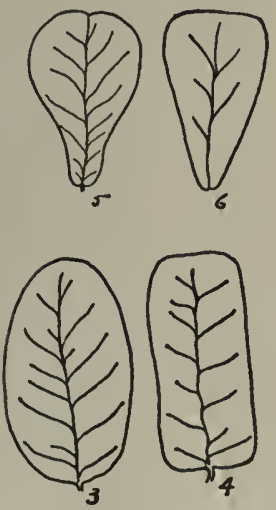

Fig. 55. 3, elliptical; 4 , oblong leaf; 5, obovate; 6 , cuneate or wedge shaped.

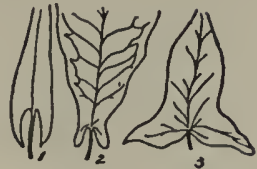

Fig. 52. $x$, sagittate; 2 , auriculate; 3 , halberd shaped.

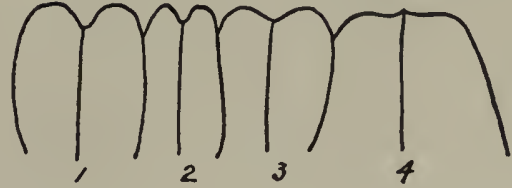

Fig. 54. Apex of leaves: $x, 3$, types of obcordate leaves; 2 , emarginate; 4 , truncate.
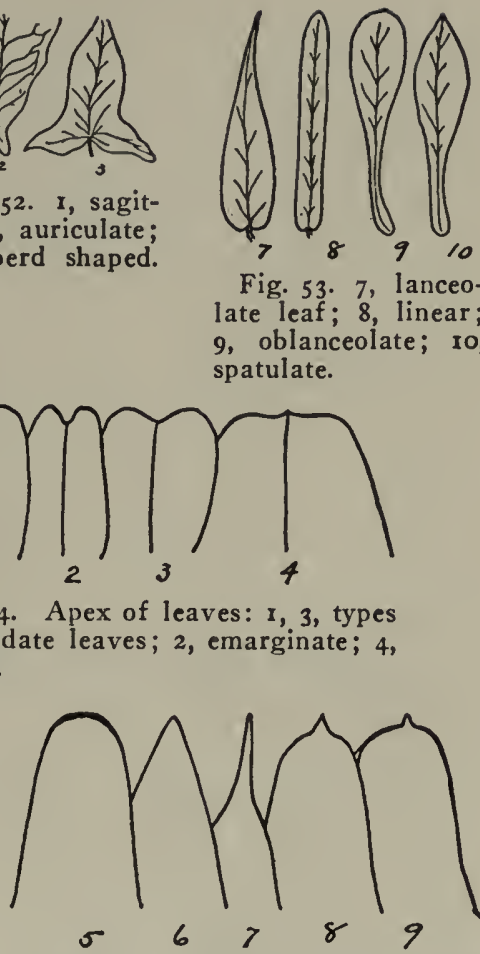

Fig. 53. 7 , lanceolate leaf; 8 , linear ; 9, oblanceolate; ro, spatulate.

Fig. 56. Apex of leaves: 5, obtuse leaf; 6 , acute; 7 , acuminate; 8,9 , mucronate.



Fig. 57. 7, shield-shaped leaf; 8, acutely three-lobed leaf; 9, peltate palmately lobed leaf of castor oil; ro, 11, types of palmately compound leaves. 
tendril. These tendrils are modified leaves, while those of the grape are modified stems.

Flowers.-Flowers are for the purpose of producing seed and are merely altered branches; the parts of flowers are therefore altered leaves. The manner in which

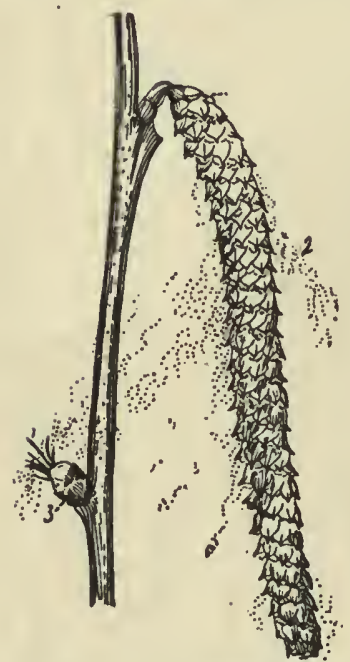

Fig. 58. Inflorescence. Catkin of birch: 2, staminate flowers; 3 , pistillate flowers.

flowers are borne upon the stem is important in enabling one to distinguish different plants. The manner in which the flowers are borne is called the inflorescence, and there are two types: the determinate, where the terminal bud opens first; and the indeterminate, where the flowers develop from below. The more important types of indeterminate inflorescence are the following:

Raceme, a simple flower cluster in which the flowers are attached to a little stalk called a pedicel, and are arranged along a common axis. Examples are : The currant, shep$h$ e r d' $s$ purse, and lily of the valley. A corymb is much like a raceme, except that the flowers are more or less level at the top and the pedicels are of different lengths. In an umbel the flower cluster is much the same as in a corymb, but the stalks are all of the same length; in other words, the flowers come from the end of the stalk.

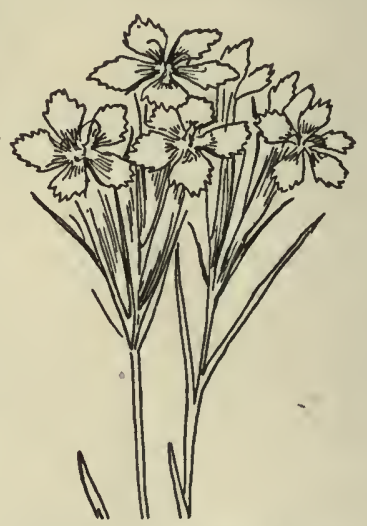
Fig. 59. Inflorescence.
Cymose cluster of pink. 
The milkweed and carrot have umbels. The spike is like a raceme with a lengthened axis, the flowers being sessile, like those of the plantain. A head is a roundish cluster of flowers which are sessile, as in the clover and buttonball. The spadix is a fleshy spike, as in the Indian turnip, the spathe being the leaf over the spadix; the flowers of the spadix are imperfect. The catkin is a type of inflorescence found in the willow and hickory. The panicle is a compound flower cluster found in many grasses; that is to say, it is like a raceme, but the
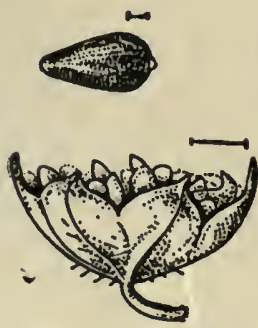

Fig. 6x. Inflorescence. Head of ragweed, achene above. (C.M.King.) stalks are branched again. Of the determinate inflorescence the

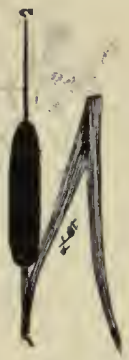

Fig. 6o. Inflorescence. Spike of cat-tail. (Dudgeon.)

most important is the cyme. The cyme is a flat topped or convex flower cluster somewhat like the corymb, but with the terminal flower developing first. A glomerule is a cyme very much compacted, resembling a head.

Flowers are perfect or hermaphrodite when provided with the essential organs, stamens and pistils; complete when they have all the floral envelopes, calyx, corolla, and stamens and pistils; regular when all the parts of each set are of the same shape and size, like the rose; irregular when some of the different floral circles are dissimilar or unequal, as in the clover, wood sage, and mint; monoecious when both staminate and pistillate

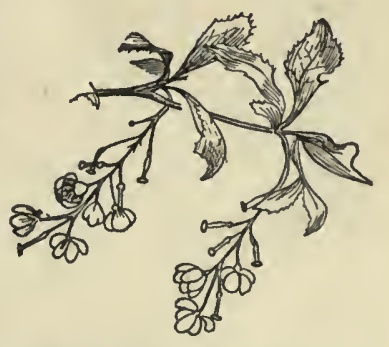

Fig. 62. Inflorescence Raceme of barberry. (C. M. King.) 


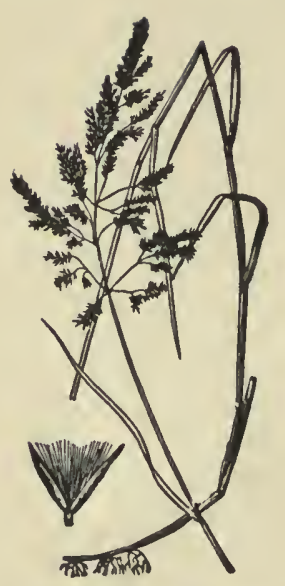

Fig. 63. Inflorescence. Panicle of grass.

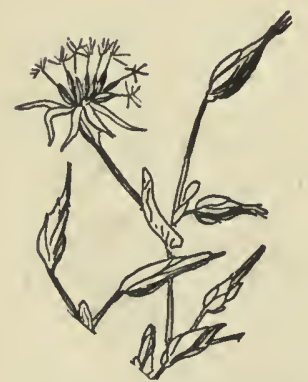

Fig. 65. Inflorescence. Head of wild lettuce. The type of inflorescence in the sunflower family. (C. M. King.) flowers are produced by the same individual plant, as in corn; dioccious when the two kinds are borne on different plants, as in willows, poplars, hemp, and moonseed. Polygamous when some of the flowers are perfect

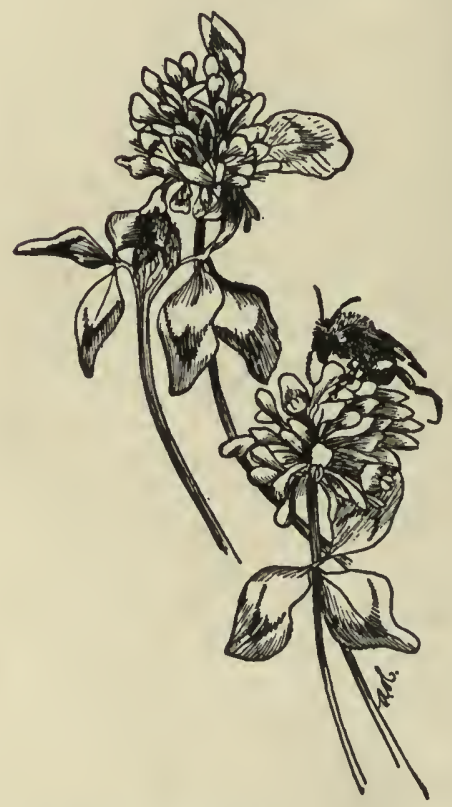

Fig. 64. Inflorescence. Head of clover. (C. M. King.)

and some have pistils or stamens only: Flowers in which the petals are sepa-. rate are called polypetalous; when the petals are united, gamopetalous; when the petals are wanting, apetalous.

In some flowers different parts or 
circles of the flower are united, this is adnation; perigynous flowers are where pistils and stamens are inserted on the calyx; occasionally they are borne from the very summit;
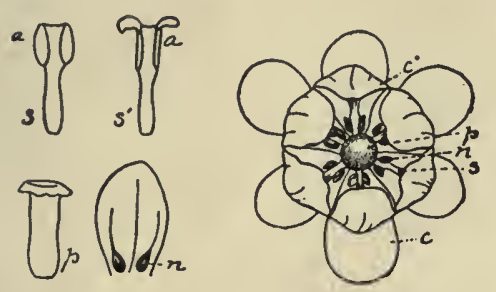

Fig. 66. Flowers of barberry: $c$, sepals; $c$, petals; $s$, stamens ; $p$, pistil; $a$, anther; $n$, nectar gland; $s^{\prime}$, stamen.

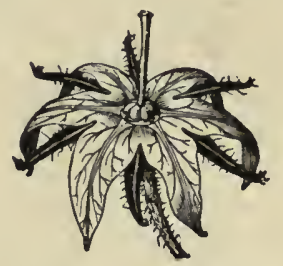

Fig. 67. Flower of tomato; small dark bodies, lobes of calyx; inner, larger lobes of petals. Stamens removed. Pistil in center. (U. S. Dept. Agrl.)

epigynous, that is adnate to the ovary; the term hypogynous is used to designate when the parts of the flower are free; such flowers are said to be superior, having a superior ovary; when adnate to the calyx, inferior.

The different types

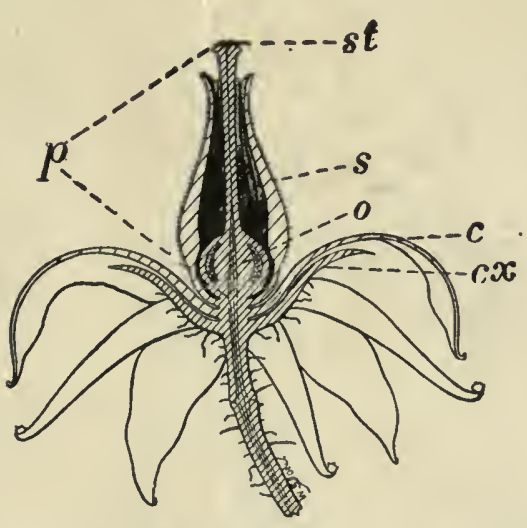

Fig. 68. Flower of tomato: $c x$, calyx; $c$, corolla; $p$, pistil; st, stigma ; $s$, stamen; 0 , ovary. (U.S. Dept. Agrl.) of corolla are: Wheelshaped, like a tomato flower, parts diverge from the center; salvershaped or salver-form

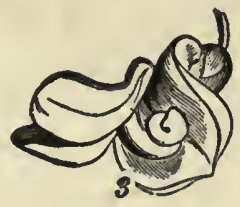

Fig. 69. Irregular flower of bean, the upper part standard or bealer, the two lower wings and the coiled keel. 


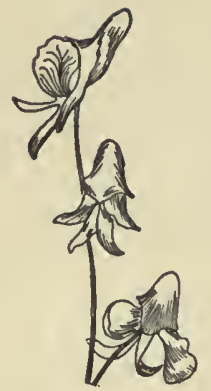

when raised on a narrow tube and diverging at right angles, like some species of the phlox family, such as gilia; bell-shaped or campanulate, with a broad and short tube like a bell, as in the common harebell; funnel-shaped or funnel-form, like the flowers of the common morning glory; tubular, when prolonged into a tube, like the trumpet honeysuckle; in some cases there are Fig. 70. Ir- little projections from regular flower the corolla, known as of aconite or Monk's hood. claws, as in the com(Ada Hayden.) mon soapwort; the conspicuous marginal flowers of the sunflower are called ray flowers; the central flowers are disk flowers, and the strap-shaped corollas are spoken of as ligulatc :orollas; the two-lipped corollas of the flower $\begin{gathered}7 \text { r. } \\ \text { of }\end{gathered}$ Irregular mint are called labiate corollas; the (Ada Hayden.)

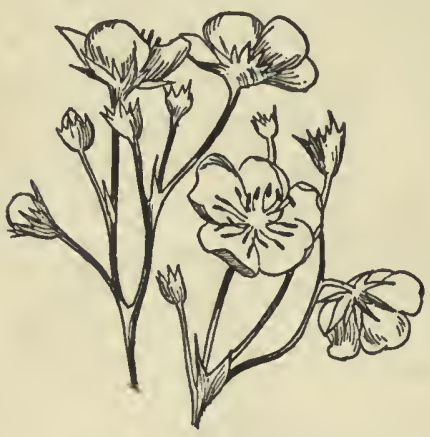
Fig. 72. Regular flower of straw- ly separate, they are said to berry: 5 petals, 5 green sepals. be distinct; when the stamens The petals of separate pieces, polypetalous. (Ada Hayden.) clover are called papilionaceous; the chafflike scales of grass flowers are called glumes.

When the stamens are inserted upon the petals, they are called epipetalous; when the pistils and stamens are united, they are gynandrous; when the stamens are entireare united by the filaments in

flowers of the sweet pea and 
one set, they are monadelphous; when in two sets, diadelphous, and so on. When there is one stamen, the flower is monandrous; two, diandrous; and so on. The parts of the stamen are the filament, anther, and pollen. When the pollen is united in a mass it is spoken of as a pollinium,

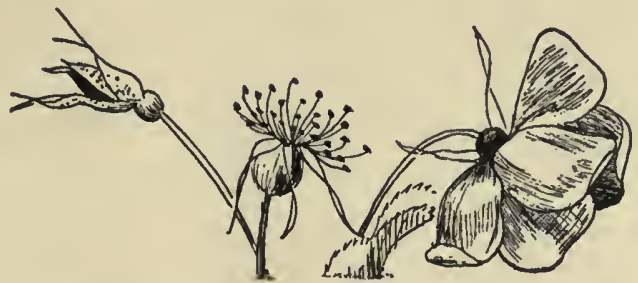

Fig. 73. Regular flower of rose: 5 green reflexed sepals, 5 petals (Ada Hayden.)

as in the milkweed. When the filament is attached in the middle it is versatile, when attached by its base it is innate, when attached by one face it is adnate. When the anther opens outwardly it is extrorse; inwardly, introrse.

Ovules, Fruits and Seeds.-There are two classes of flowering plants classified with reference to the manner in which the ovules occur. In the Gymnosperms, the ovules and seeds are borne on the face of a scale, as in the pine, spruce and cedar. In the Angiosperms, the ovules and seeds are contained in a closed ovary, as in the bean, corn, maple, etc. The carpel is a modified leaf forming the ovary or a part of the compound ovary. The dorsal suture corresponds to the midrib of the leaf, the ventral

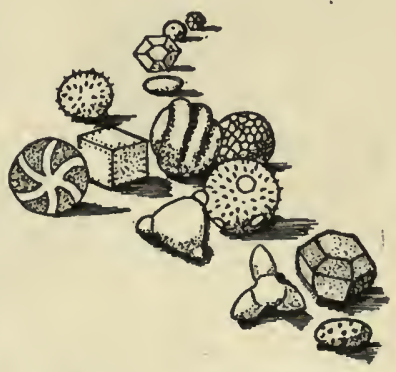

Fig. 74. Pollen grains of various types. (Redrawn from Hamilton-Gibson. C. M. King.) 
suture is where the leaves meet. The placenta is that part of the ovule where the ovules are borne. An axile placenta occurs in a compound pistil where two or more closed carpels cohere; such ovaries are two, three or more celled. A parietal placenta appears in a compound pistil when the ovules are borne on the walls of the ovaries, as in the poppy and Rocky Mountain bee plant. In pinks and purslane, the compound pistil is one-celled with a free placenta. The parts of an ovule are the two coats, an

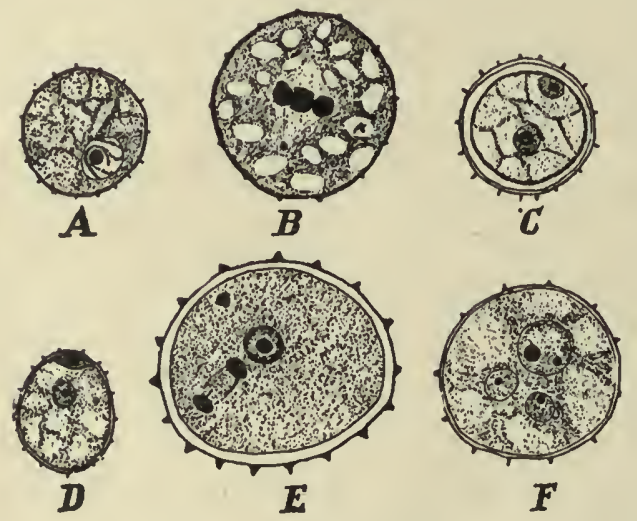

Fig. 75. Pollen grains in a stage preceding the formation of a pollen tube. $A-F$, different stages. (Caldwell-Coulter.)

outer and an inner, the chalaza at the base where the coats and nucellus blend; the nucellus, is the body of the ovule. The micropyle is the opening left after the passage of the pollen tube into the ovule. There is usually a stalk called the funiculus on the seed; the embryo sac contains the egg cell. Ovules may be crect when they arise from the bottom of the cell; ascending, when extending upward and attached at the side; horizontal, when borne on the side horizontally as in mandrake; suspended, when hanging from the apex; pendulous, when more or less hanging or 
declining from the side. The term orthotropous is applied to the straight ovule, as in buckwheat; campylotropous,

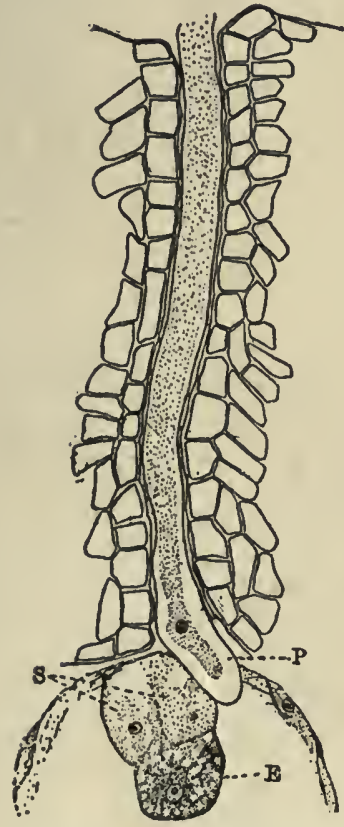

Fig. 76. Fertilization in the cotton plant. $P$, pollen tube passing down the style ; $E$, egg cell in embryo sac, which unites with a cell of the pollen tube. (Duggar.)
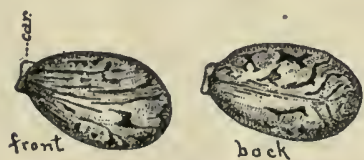

Fig. 79. Two views of castor oil bean; car., caruncle. (C. M. King.)

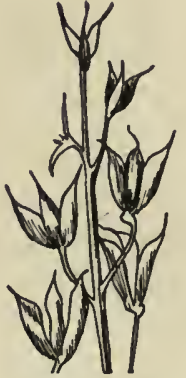

Fig. 78. Fruit known as a follicle of larkspur. (Ada Hayden.)

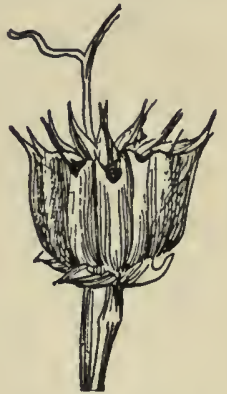

Fig. 77. A cluster of carpels of Indian mallow or butterprint. M. King.)

(C.
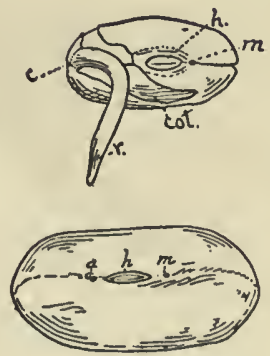

Fig. 8o. Bean seed : $m$, micropyle; $h$, hilum; $r$, radicle; $c$, caulicle; cot., cotyledon. (C. M. King.) 
when the ovule is curved on itself, as in chickweed; amphitropous, when the body of the ovule stands transversely to the stalk; anatropous, when the ovule is inverted and the opening close to the hilum; the ridge extending along the ovule is called the raphe.

The fruit is the matured pistil, including whatever parts are attached to it. The seed vessel is called the pericarp. The principal kinds of fruit are: The simple fruit, resulting from the ripening of a single pistil, an ex-

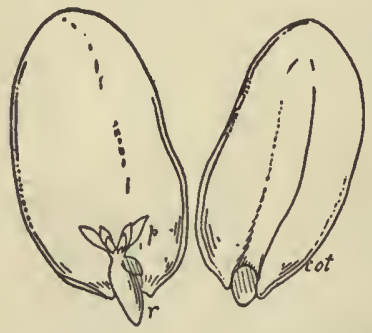

Fig. 8r. Two cotyledons of bean; $r$, radicle; $p$, plumule. An exalbuminous seed or a seed without endosperm. (C. M. King.) ample being the bean pod; the simple fruits are divided into the dry fruits, stone fruits and berries; an aggregate fruit formed when a cluster of carpels of a single flower are crowded in a mass, as in the raspberry; and multiple fruit formed by the union of a cluster of pistils of several flowers, as in the mulberry.

Fruits may also be divided into dehiscent and indehiscent. The dehiscent fruits are representerl by the legume, a true pod which comes from a simple pistil with dehiscence on both sides, as in the pea and bean ; the follicle, a pod formed from a simple pistil and dehiscent by the ventral suture, as in the larkspur; capsule, a dehiscent fruit of a compound pistil. Modifications are a pyxis, which opens by a circular line, as in the purslane and plantain; silique, like the pod of the mustard, which has two parietal placentæ. The indehiscent fruits are nearly always oneseeded, the more important kinds being the achene (achenium), a one-seeded, seedlike fruit, like that of the sunflower, buttercup and smartweed; samara, a keylike fruit provided with a wing, as in the maple and ash; the utricle, somewhat like an achene, but with a loose membrane, 
as in goosefoot or lamb's quarter; caryopsis, a grain fruit in which the wall of the ovary and the testa are closely united; a nut, a hard one-celled and one-seeded fruit, usually produced from an ovary with two or more cells, as in the hazelnut and acorn; and the paired fruits, as the cremocarp of the parsnip, each half of which is a mericarp.

The more important fleshy fruits are represented by the drupes or stone fruit, such as the peach and plum; the pome, as the apple, the fleshy part of which is the enlarged calyx; the pepo or gourd fruit, like the squash; the berry, as the grape, which is fleshy. The fruit of the pine is called the strobile.

The Seed.-The seed is the fertilized ovule and consists of the following parts: The funiculus (occasionally
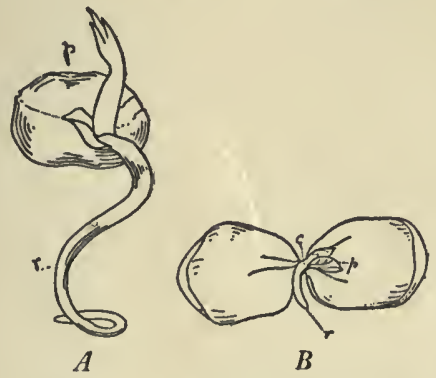

Fig. 82. $A$, germinating pea; $r$, root; $p$, young stem. $B$, Two cotyledons of pea; $p$, plumule; $c$, caulicle. (C. M. King.) lacking) or the stalk; the outer and inner coats-the outer, frequently hard, called the testa, the inner known as the tegmen; the micropyle or place where the pollen tube enters the ovule; the hilum or scar $\mathrm{s}$ h o w i n g where the seed was attached to the ovary. The albumen, when present may be all endosperm, as in the starchy part of corn, or perisperm, as in canna; this corresponds to the nucellus of the ovule. Some seeds may contain both endosperm and perisperm, as in the pepper. Mea. Most seeds have a small quantity of peri- Cotyledons resperm present. The embryo of the seed gives main in seed. rise to the new plant and consists of the

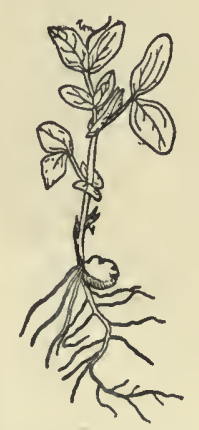

Fig. 83. Ger(C. M. King.) 
radicle, or true root; the caulicle, or stem ; and the cotyledons. When there is one cotyledon the plant is monocotyledonous, when two it is dicotyledonous, when three or more, polycotyledonous; the plumule rises from the caulicle. In germination, the cotyledon or cotyledons may remain in the seed, in which case they are said to be hypogaeous, as in the pea; when they are pushed out, as in the bean, they are epigaeous.

Seeds may be smooth, as in the bean; rough, as in corncockle; they may have a thin membrane growing out from the surface, in which case the seed is said to be winged.
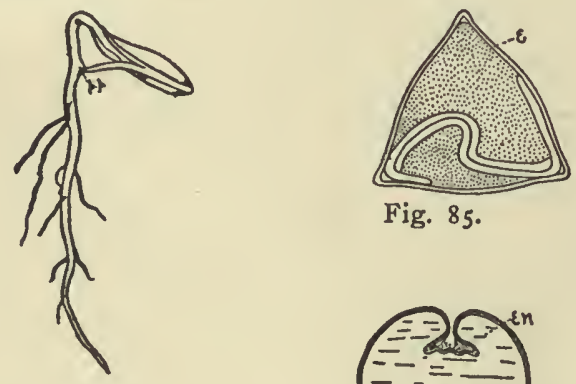

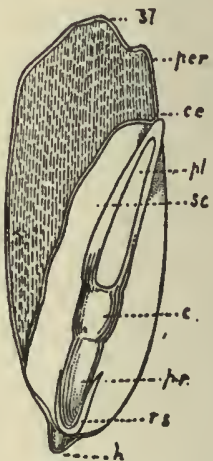

Fig. 87 .
Fig. 86.

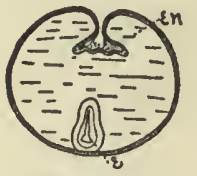

86.

Fig. 84. Squash seed germinating. Root below and cotyledons pushing out: $p p$, pumpkin peg holding the testa.

(C. M. King.)

Fig. 85. Cross section of buckwheat "seed," an achenium: $e$, wall of ovary, inner line represents the testa. Embryo with two cotyledons surrounded by the endosperm; seed albuminous. (C. M. King.)

Fig. 86. Cross section of date seed: en, hard and horny endosperm, embryo small in lower part of seed. "Seed albuminous. (C. M. King.)

Fig. 87. A longitudinal section of kernel of corn; an albuminous seed: $c e$, endosperm; $p l$, plumule; $s c$, scutellum; $c$, caulicle; $p r$, primary root; $h$, point of attachment of kernel to cob; rs, root sheath. The darker portion represents the endosperm, light portion embryo or germ. (C. M. King.) 


\section{DESCRIPTIONS OF SOME COMMON WEEDS}

The More Important Families of Weeds.-The weeds described in the following pages are quite widely distributed. Many of them are as common in New England as in the Northern Mississippi valley and many of them are common on the Pacific coast. Some weeds are local, such as the tarweed of California. Those who are especially interested in a further study of the various regions should consult some of the manuals and floras, such as Robinson and Fernald, Gray's "New Manual of Botany" and Britton's "Manual of Northeastern United States."

\section{KEYS TO FAMILIES}

I. Plants producing spores, in spore cases or sporangia.

Rushlike and jointed (Equisetaceae). P. 138 .

Not rushlike nor jointed (Polypodiaceae). P. r 37.

Plants producing pollen and ovules, which develop into seeds.

2. Embryo of one cotyledon; stem endogenous with no distinction between pith wood and bark; leaves generally par-

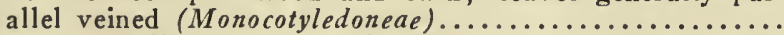

Embryo usually with two cotyledons; stems with distinct wood pith and bark; leaves netted veined (Dicotyledoneae).....

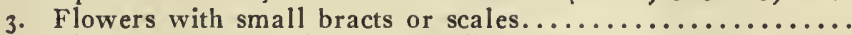

Flowers with a perianth, petal-like, and having parts colored alike (Liliaceae). P. I59.

4. Scale I (Cyperaceae). P. I57.

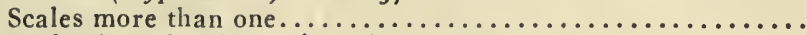

5. Scales in pairs (Graminece). P. r 39 .

Perianth of six similar scales (Juncaceae). P. I58.

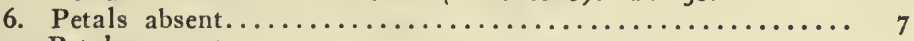

Petals present........................... 12

7. Flowers monoecious, dioecious or polygamous.

Fruit, a three-lobed, three-seeded capsule. Plants with milky juice (Euphorbiaceae). P. 193.

Fruit, one-seeded (Urticaceae). P. r6o.

8. Fruit, not an achene; fleshy plants with a coiled embryo...... Fruit, an achene. 
Flowers with sepals, embryo straight (Polygonaceae). P. I62.

Flowers without floral envelopes (Piperaceae). , P. 160.

9. Fruit, an utricle........................... ro

xo. Flowers, with bracts (Amaranthaceae). P. 270.

Flowers, without bracts...................... II

x r. The persistent calyx inclosing the fruit (Nyctagineaceae). P. r62.

Calyx not persistent; sepals green or greenish (Chenopodiaceae.)

P. 167.

12. Flowers, polypetalous........................ 3

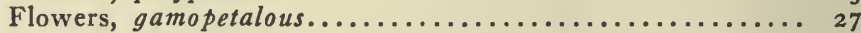

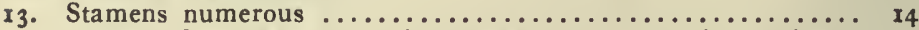

Stamens few, as many as the petals, or not more than twice as

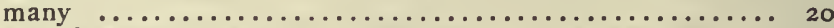

14. Calyx free from the ovary; pistil, one or more than one.... I5

15. Pistils numerous, or more than one.............. r6

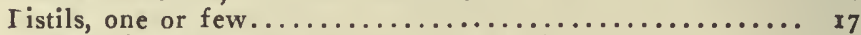

16. Stamens inserted on the calyx (Rosaceae). P. 185.

17. Stamens, monadelphous or diadelphous.

Fruit a legume (Leguminosae). P. 187 .

Pistils united into a ring (Malvaceae). P. $x_{3} 6$.

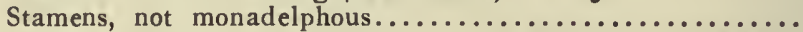

18. Stamens inserted on the receptacle, leaves not punctate $(R a-$ nunculaceae). P. 177 .

Stamens inserted on the receptacle in clusters, leaves punctate, flowers yellow (Hypericaceae). P. 202.

19. Ovary compound, one-celled; fleshy herbs (Portulacaceae). P. x76.

Ovary compound; pistil one, carpels two or more; plants with milky or colored juice (Papaveraceae). P. 178 .

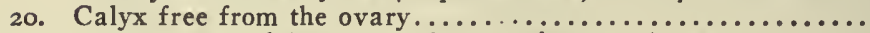

21. Ovary 1, 2-4-lobed, or entire (Sapindaceae). P. r98.

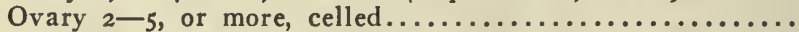

22. Leaves dissected (Geraniaceae). P. 19x.

Leaves trifoliate (Oxalidaceae). P. rgr.

Leaves pinnately compound (Zygophyllaceae). P. 192.

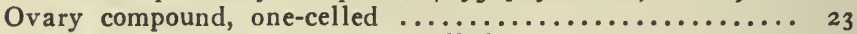

Ovary compound, two or more celled................ 25

23. Flowers, irregular, stamens five (Violaceae). P. 203.

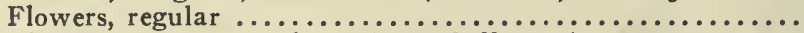

24. Flowers, perfect, regular (Caryophyllaceae). P. I73.
Flowers, monoecious or dioecious (Euphorbiaceae). P. r93.

25. Ovules, solitary, trees or shrubs (Anacardiaceae). P. r98.

Ovules few, stamens six, tetradynamous (Cruciferae). P. 179 .

Ovules few, stamens six, not tetradynamous(Capparidaceae). P. I84.

26. Ovary 2 to several-celled, stamens 8 or 4 (Onagraceae). P: 204 .

Ovules and seeds, only one in each cell, stamens five, flowers

in umbels (Umbelliferae). P. 205.

27. Calyx free from the ovary, superior................ 28

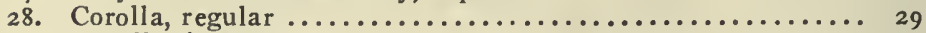

Corolla, irregular .................................. 35

29. Ovaries of two carpels........................ 30 


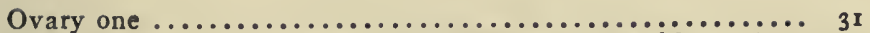

30. Pollen in pollinia, stamens monadelphous (Asclepidaceae). P. 209.

Pollen not in pollinia (Apocyanaceae). P. 208.

3I. Ovary deeply four-lobed, leaves opposite (Labiatae). P.218. Leaves alternate (Boraginaceae). P.215.

32. Fruit a berry (Solanaceae). P.220.

Fruit not a berry............................. 33

33. Ovary I-2-celled, seeds mucilaginous (Plantaginaceae). P.225.

Ovary $2-3$-celled, parasitic or twining, large or small flowers

(Convolvulaceae). P. 2 ro.

Ovary $2-3$-celled, plants not twining............... 34

34. Pod, many-seeded, styles two (Hydrophyllaceae). P.214.

Style I, branches or lobes of stigma 3 (Polemoniaceae). P. 2 I4.

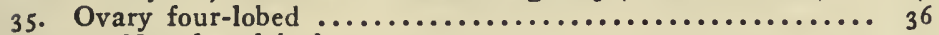

Not four-lobed $\ldots \ldots \ldots \ldots \ldots \ldots \ldots \ldots \ldots \ldots \ldots \ldots \ldots \ldots, 37$

36. Stamens inserted on the corolla tube, stem not four-sided, leaves alternate (Boraginaceae). P.215.

Stamens not inscrted on the corolla tube.............. 38

37. Ovary one-celled (Orobanchaceae). P. 225.

Ovary one, pod two-celled (Scrophulariaceae). P.223.

38. Stamens united by their filaments, ovary one-celled (Compositae). P.229.

Stamens united by their filaments, ovary two or more celled. Corolla irregular (Lobeliaceae).

Corolla regular (Campanulaceae). P.229.

Stamens not united by their filaments..................

39. Ovary $2-5$-celled leaves whorled, with or without stipules; fruit an indehiscent capsule (Rubiaceae). P 227.

Ovary 2-5-celled, leaves not whorled, but with small stipules (Caprifoliaceae). P.228.

Ovary one-celled (Dipsaceae).

Fern Family (Polypodiaceae).-Plants with horizontal rootstocks; leaves entire, pinnate, pinnatifid or decompound; sporangia (spore cases) collected in dots (sori) on the back of the frond, either covered with a membranous indusium or naked; sporangia from an incomplete, many-jointed ring. A large order of about 3,000 species of wide distribution, a few of which, like the shield fern (Asplenium Filix-mas), are used in medicine.

Common Brake (Pteris aquilina, L.).-A dull-green, tough frond from a stout, black, woody rootstock; very variable in height, varying from two to six feet; stipe straw-colored or brownish; branches of frond twice-pinnate; pinnules oblong-lanceolate, the upper undivided; 
sori on margin of frond. Found across the continent, also in Europe.

Horsetail Family (Equisetaceae.)-Rushlike herbs with jointed and hollow stem from running rootstocks; the fertile stem, with a conical or spikelike body which contains a shield-shaped body beneath, the spore case, which contains the spores; spore is furnished with two straplike bodies called the elaters; the spores develop into the prothal-

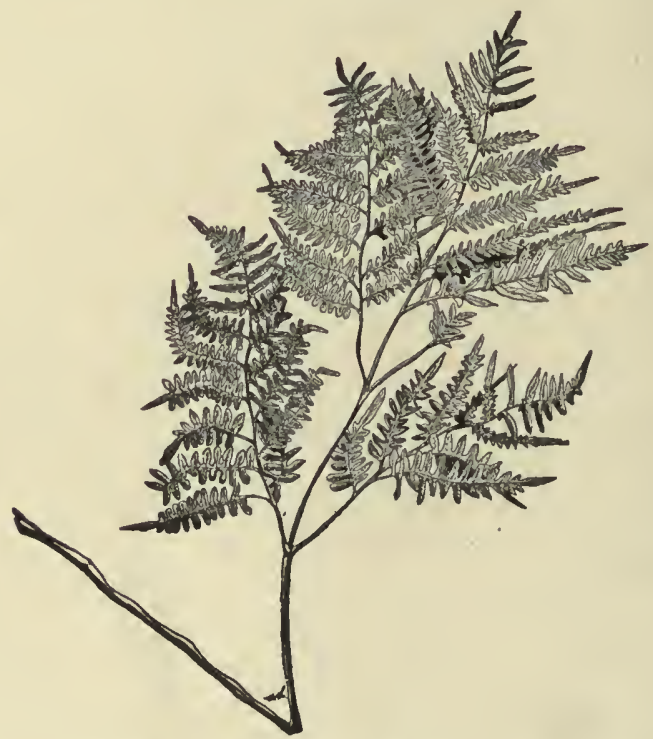

Fig. 88. Common brake (Pteris aquilina). (Ada Hayden.)

lus from which the horsetail develops. The family contains a single genus, Equisetum, with 25 species.

Common Horsetail (Equisetum arvense, L.).-An annual-stemmed perennial producing two kinds of plants; the fertile from four to ten inches high, yellowish brown in color, sheaths eight to twelve-toothed; the sterile plants slender branched, with four-angled stem and four-toothed 
sheaths. Conmon in moist, sandy soil and fields, and along railways.

Grass Family (Gramineae).-Fibrous-rooted annuals or perennials, rarely woody, with hollow stem; alternate, two-ranked leaves; sheaths split or open on the side opposite the blade; flowers consisting of two-ranked glumes, forming a one to many-flowered spikelet; flowering glumes inclosing a small bract called the palet; stamens one to six, usually three; anthers versatile, two-celled; stigmas hairy. A large family of about 3,500 species, many of which, such as wheat, corn, oats, and wild rice, are very important to man. Sorghum and sugar cane, which furnish the sugar of commerce, also belong to this family.

Johnson Grass (Sorghum halapense, (L.) Pers.).-An erect, stout perennial three to five feet tall, with simple, smooth stem. and strong creeping rootstocks; leaves elongated, acute, and, where the leaf-blade joins the sheath, the back is more or less pubescent; open panicle six to twelve inches long, the whorled branches being naked below, with three to five-flowered racemes clustered near their extremities; pedicels of the staminate or neutral spikelets armed with stout hairs, the sessile spikelet broadly lanceolate, acute, pale green or violet, becoming dark or nearly black at maturity; first glume five to seven-nerved, second glume similar and equaling the first, third shorter, outer ones faintly two-nerved and the fourth two-lobed, awned, ciliate, one-half as long as the second; blooming period all summer. This plant has been introduced and cultivated in many parts of the southern states for hay, but has become, in various sections, a dangerous weed and is difficult to exterminate.

Smooth Crab Grass (Digitaria humifusa, Pers.).-An annual from six inches to two feet tall, closely resembling finger grass (D. sanguinalis), in habit, but is smooth throughout excepting for a few hairs at the throat of the sheath; spikes two to six, widely diverging and smaller 
than those of finger grass; first glume very minute, second and third larger and nearly of equal length, or the second a little shorter than the fourth, the upper empty glume equaling the flower. The blooming period from June to September. Quite common in eastern and central Iowa,

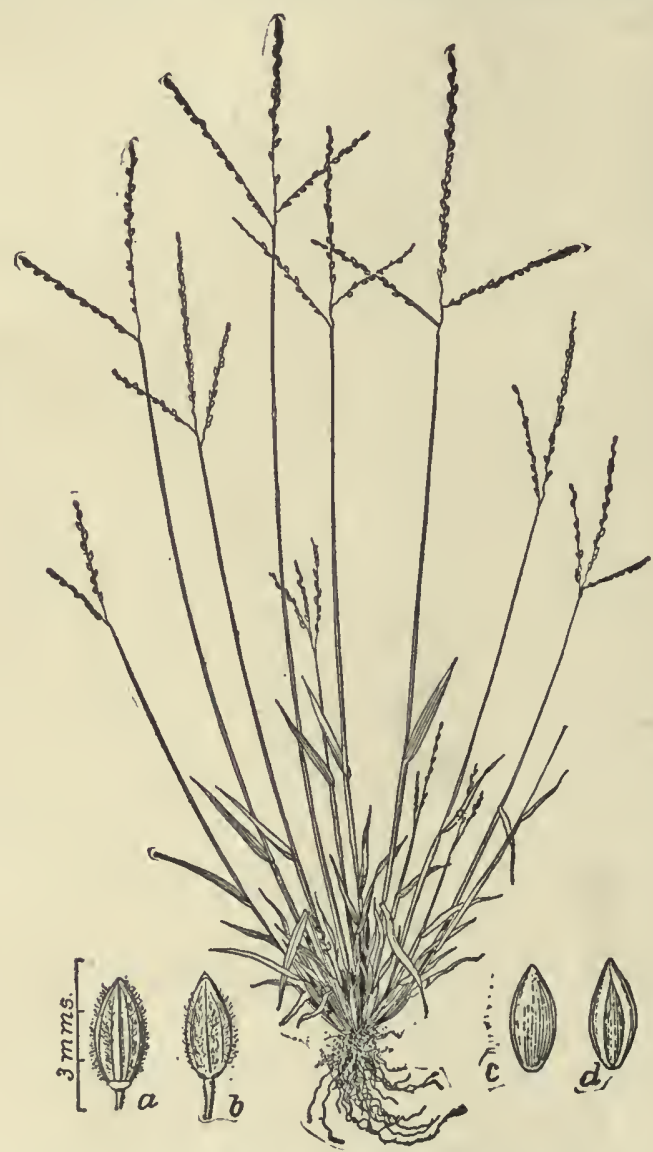

Fig. 89. Smooth crab grass (Digitaria humifusa). (U. S. Dept. Agrl.) 
especially in the flood plains of streams, and becoming troublesome as a weed on lawns.

Finger Grass or Crab Grass (Digitaria sanguinalis, (L.) Scop.).-A leafy, much-branched annual, one to three feet high, spreading on the ground, with erect, smooth, spreading stems, frequently rooting at the lower joints, which are sometimes smooth, but, more often, bearded with deflexed hairs; sheaths loose, generally hairy, especially on the margins, with a membranaceous ligule; leaves from two to four inches long, with rough margins and occasionally hairy at the base; flowers produced in digitate spikes (hence the name finger grass); spikelets in pairs, less than one-eighth inch long, one being nearly sessile, the other on a small stalk; each flower consists of two sterile glumes and the flower proper, which is made up of two glumes; the first glume is very small, the second about one-half to two-thirds as long as the spikelet, the third somewhat longer than the fourth, and the fourth, five-nerved and usually silky haired along the marginal nerves, smooth and acute; fruit minute, pitted and cross-striated, light straw colored, except where the sterile glumes remain attached. These are gray and minutely hairy. Blooming period from June to September. Common in the bottom lands along streams and occasionally troublesome in corn fields, but more of a pest on lawns. Since it roots at the joints, it is somewhat difficult to remove.

Old Witch Grass (Panicum capillare, L.).-An annual, usually displaying coarse, branching stems, one to three feet high, with very hairy leaf sheath and wide-spreading panicles, which are terminal on the stem and branches; stem jointed, branching near the base and hairy below the bearded nodes; sheaths have spreading hairs and densely ciliate short ligules; leaf blade flat, lanceolate or linear and sparingly hairy on both sides, with rough margins; hairs throughout spring from small papillæ, those on the leaf 
blade being confined to the principal nerves; panicle diffuse, branches solitary, in pairs, or whorls; spikelets very small; blooming period from July to October. Quite common throughout the state and frequently becoming a weed. Rather variable in appearance; in cultivated fields being stout and bristly, but in moist meadows and old lake beds becoming slender and hairy rather than bristly.

Sprouting Crab Grass (Panicum dichotomiflorum, Michx.).-An annual with a thick, spreading or ascend.ing, branching, glabrous stem, two to six feet high; leaves flat, seven to fourteen inches long; panicles diffuse, terminal or lateral; sheaths smooth, lax, somewhat flattened; spikelets rather crowded upon short, scabrous pedicels; anthers saffron-yellow; blooming time from July to October. Low waste grounds and cultivated fields from Maine to Nebraska and southward.

Barnyard Grass (Echinochloa crus-galli, (L.) Beauv.).A coarse, ascending, leafy annual from one to five feet high; stems frequently branched near the base; sheaths loose and smooth as a rule, although occasionally appearing rough ; leaves broad, flat and six inches or more long, smooth or rough with rough margins; spikelets densely crowded in several rows along one side of the spikelike branches of the panicle; outer glume or bract from onefourth to one-half the length of the spikelets, second and third glumes smooth and hairy or rough along the nerves, third glume awnless or short pointed; blooms all summer. Common throughout eastern United States except in the extreme northern parts.

Yellow Foxtail or Pigeon Grass (Setaria glauca. (L.) Beauv.).-An erect annual, one to two and one-half feet high, with flat leaves and a bristly cylindrical spike, one to three inches long; heads slender with tawny red bristles, five to ten on each spikelet; axis of the flowering stalk densely pubescent; blooms from June to September. 
Widely distributed all over northern United States, and a pernicious weed in cultivated fields.

Bristly Foxtail (Setaria verticillata, (L.) Beauv.).-A low, spreading, much-branched annual from one to two and one-half feet high; lanceolate leaves, two to seven inches long, somewhat narrower than those of $S$. viridis, and from one-fourth to one-half inch wide; sheaths smooth, rough on the margins and veins; spike cylindrical from one to five inches long, composed of short, cylindrical clusters, with short bristles, a little longer than the spike, either single or in pairs and barbed downward; seeds - small, greenish, minutely cross-striated and wrinkled; blooming time from June to September. Quite abundant in the East, and west to Nebraska; unless strong measures are taken to eradicate it, it will soon become as troublesome as the other species. Because of its downwardly barbed bristles, it is easily disseminated by animals.

Green Foxtail (Setaria viridis, (L.) Beauv.).-A smooth, erect annual, from one to three feet high, with leaves long, rough margined, greenish, more or less compound, cylindrical spikes from one to six inches long, with few bristles; spikelets shorter than the bristles, about one-half inch long, the chaff of the second and third glumes equaling the minute chaff of the fourth glume, which is faintly transversely wrinkled below or only striate and pitted; blooms from July to September. A single head of the green foxtail produces an enormous number of seeds, which appear to have considerable vitality, hence when the plant once becomes established in a field, it is very difficult to remove it. This difficulty is increased by the habit of the grass of forming tufts. The species common in the northern states and a troublesome weed in corn fields.

Sandbur (Cenchrus tribuloides, L.).-An erect annual one to four feet high, with spreading, or ascending, much- 
branched stems, rarely a foot high, somewhat compressed; leaves flat or simply folded, linear, about six inches long,

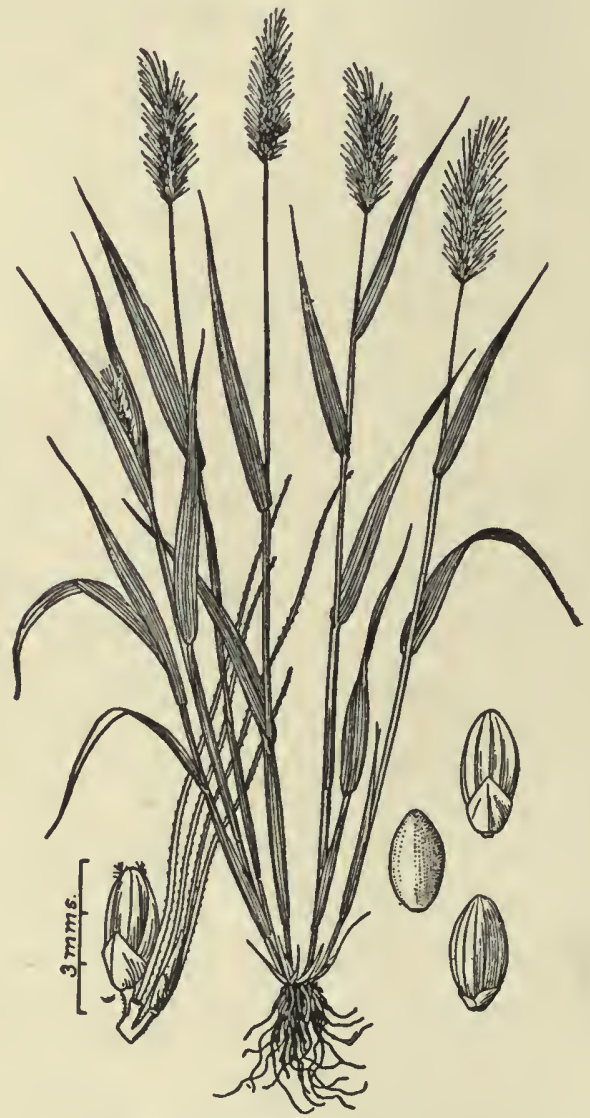

Fig. 90. Green foxtail (Setaria viridis). (U. S. Dept. Agrl.)

very finely toothed on the margins; sheaths, generally longer than the internodes, hairy along the margins and at the throat; burs containing the spikelets, six to twenty, 
nearly round, covered with strong, more or less pubescent, barbed spines, becoming very hard at maturity, and readily falling off; blooms from June to October. Found in sandy fields along the Mississippi, and other streams, southern states, and on the Pacific coast. Distributed by means of the seeds and burs which cling to the fur or hair of animals. It injures stock which eat it, because the burs produce inflammation.

Rice Cut Grass (Leersia oryzoides, (L.) Swartz).- A rather stout, rough and usually much-branched grass, two to four feet high, with flat leaves, and an open, palegreen or straw-colored panicle; nodes usually bearded; sheaths eared, scabrous on the sides at the apex; very rough, the points of the minute spines directed downward; ligule membranaceous; leaf blade three to ten inches long, very acute, contracted, often hairy at the base, rough on both surfaces, margins very rough, with minute sharp spines, which on the lower part of the leaf are directed toward the base, and on the upper part are directed forward toward the apex; panicle six to ten inches long, the slender ascending branches two to four inches long, naked below, flower-bearing toward the ends, spikelets rather flat; stamens, three; within the lower sheaths may be found cleistogamic or hidden fruiting spikelets; flowers in August and on through October. Found along streams and ditches and in marshes, usually in the open; common.

Canary Grass (Phalaris canariensis, L.).-An erect annual, one to three feet tall, with flat leaves and a dense, ovoid panicle, or head about one inch long; two empty glumes, white, with green veins; third and fourth glumes rudimentary, being scalelike and smooth; fifth or flowering glume hairy; blooms in July and August. Naturalized in northern states, the seed being used extensively as a bird food.

Vanilla Grass or Holy Grass (Hierochloe odorata, (L.) 
Wahlenb.).-A perennial grass with creeping, fragrant rootstocks, one to two feet high; panicles somewhat onesided, two to five inches long; spikelets chestnut-colored, three-flowered; the two lower flowers staminate, hairy fringed, with three stamens, the upper flower perfect, short pediceled, awnless and with two stamens. Common in the mountain regions and in the north. Frequently a troublesome weed in Minnesota and Northwest Territory.

Western Stipa (Stipa comata, Trin. and Rupr.).-Also known as needle grass, a rather stout, erect perennial, growing one and one-half to four feet tall and forming tufts or mats; leaves rolled inward (involute); loosely flowered panicles, eight to twelve inches long; spikelets with nearly equal, long-pointed glumes about twice as long as the thinly pubescent, flowering glume; awn slender, two and one-half to three inches long, strongly bent and twisted; blooming period from May to September. Rather rare in Iowa, few specimens having been reported. Common and abundant in northwest Canada and on the plains west of the Missouri river.

Needle or Porcupine Grass (Stipa spartea, Trin.).-A stout, erect perennial with simple stems three to five feet high; leaves long and narrow; plant bears few flowers and these are carried on large, open panicles four to eight inches long; seed long-awned, bearing a sharp-pointed callus with barbs extending upwardly, which enable the seed to bury itself; blooming period from June to August. Common on dry, gravelly soils throughout the northern Mississippi valley states and frequently found in prairie hay; especially injurious to horses, cattle and sheep, producing severe inflammation and occasionally causing death.

Poverty Grass (Aristida dichotoma, Michx.).-A slender, tufted, branched annual from twelve to twenty-four inches tall; spikelets in narrow, striate, simple or com- 
pound spikes; empty glumes nearly equal, longer than the flowering glumes, equaling the small lateral awns; awns unequal, the long middle awn horizontal, soon becoming reflexed. Common in dry, sterile or clay soil southward.

$A$. oligantha is a tufted annual, bearing loosely, fewflowered racemes, leaves short; awns all diverging and alike. Common in dry fields, especially southward; occurring as far north as Iowa. A. fasciculata is the sand grass of the plains. It is a perennial with long, spiked panicles.

Nimble Will (Muhlenbergia racemosa, (Michx.) B. S. P.).-A rather stout, upright perennial, with very rough, densely scaly rootstocks, and nearly simple stems, two to three feet high; densely flowering panicles two to four inches long, contracted into an interrupted, long-peduncled spike with sessile branches; long acuminate-pointed outer glumes nearly equal and exceeding the very acute flowering glume, which is densely bearded at the base; blooms from July to September. Occurs in the northern Mississippi valley, a rapid grower and affords some forage when young. Troublesome weed.

Mexican Drop Seed (Muhlenbergia mexicana, (L.) Trin.).-An upright or ascending, usually much-branched perennial, one to three feet high, with a scaly, creeping rootstock, numerous flat leaves and contracted, densely flowered panicles; sheaths smooth; leaf blades two to seven inches long; panicles lateral and terminal, often included at the base, densely spike-clustered, linear, green and purplish; spikelets on very short pedicels, the empty g'umes nearly equal, about the length of the floral glume, rough on the keel, floral glume lanceolate, acute or mucronate-pointed, three-nerved; blooms in August. IVidely distributed and abundant in all parts of the state; somewhat variable in form, approaching at times the marsh Muhlenberg in density, but when cut off before 
heading, the spikes become more slender, and the plant might be readily mistaken for another species. The grass matures rapidly and affords early forage, but later becomes woody. In cultivated gardens and fields it is a troublesome weed. The wild timothy ( $M$. racemosa) has thick spikes-common weed in low grounds.

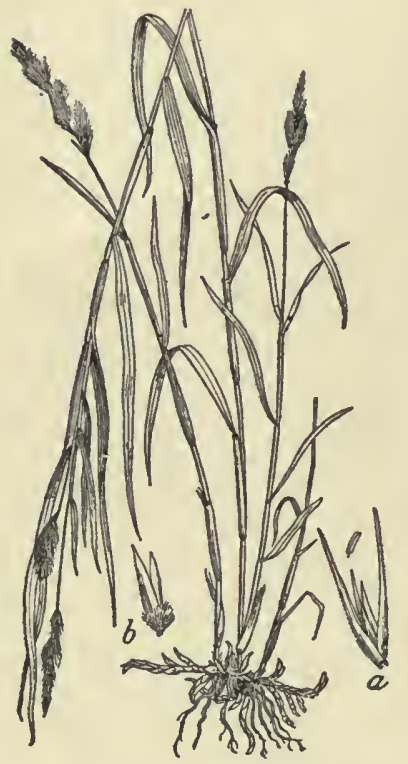

Fig. 9x. Muhlenbergia racemosa. a, spikelet with long, acuminate-pointed outer glumes; $b$, flowering plume, bearded. (Div. of Agros., U.S. Dept. Agrl.) erally throughout the United States; common along the Mississippi and Missouri rivers, waste places and fields in Missouri.

Sheathed Rush Grass (Sporobolus vaginiflorus, Wood). 
-A slender annual growing one to three feet high, forming mats or turf; leaves very narrow, short and simple, few-flowered, terminal and axillary, spikelike panicles about one inch long and mostly inclosed in the somewhat inflated leaf sheaths; spikelets short; blooms in August and September. Rather common in dry fields and waste places, especially toward the South.

Small Rush Grass (Sporobolus neglectus, Nash).-A smooth, erect annual from six to twelve inches high, springing from a usually decumbent base, slender often, much-branched; sheaths about half as long as the internodes and inflated; leaves narrow at the base, smooth beneath, rough and hairy near the base above, attenuated into a slender point, lower leaves elongated, the upper one to three inches long and dry; terminal panicle one to two and one-half inches long, usually more or less included in the upper sheath; lateral panicles inclosed in the sheaths; blooming period in August and September. Very generally distributed in eastern North America.

Red Top (Agrostis alba, L.).-A well-known perennial of exceedingly variable habits, with a smooth stem that is either erect or decumbent; roots at the base or puts out stolons; from one to three feet high; sheaths smooth; leaf blade linear or narrow-lanceolate, four to eight inches long and smooth; panicle narrow, with erect, rather densely flowered branches, or lax and open, with widely spreading branches; spikelets nearly sessile, or sometimes with pedicels; flowering glumes slightly shorter than the empty glumes. Blooms from June to September. Common throughout the United States excepting in the extreme South. Found very generally in the North, usually growing on low grounds and is an excellent forage plant. Sometimes troublesome in oat fields.

Wild Oats (Avena fatua, L.).- An erect, smooth annual, three to five feet high, with flat leaves and spreading panicles of large oatlike, two to four-flowered spike- 
lets; flowering glumes covered with long, brownish hairs and each bears a bent awn nearly twice as long as the spikelets; blooms from June to September. Abundant

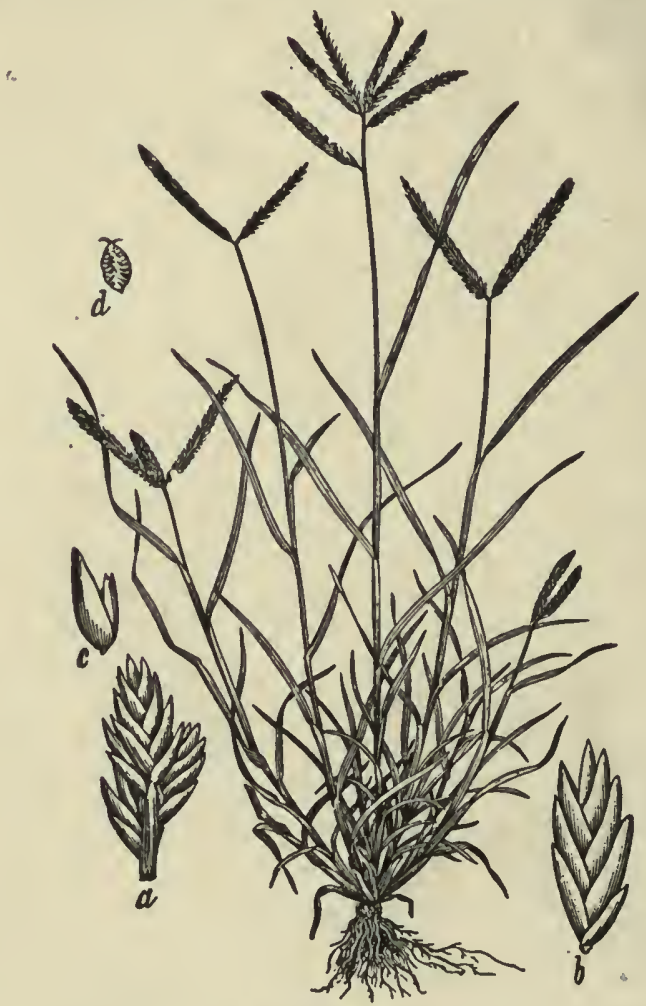

Fig. 92. Crowfoot grass (Eleusine indica). (U. S. Dept. Agrl.)

especially in the northern states, and in the Rocky Mountains, and although much esteemed as a forage plant in some sections of the country, notably in California, it is a pernicious weed in grain fields.

Wire Grass (Eleusine indica, Gaertn.).-A coarse, tuft- 
ed annual, with erect or spreading, flattened stems, six to twenty-four inches high; sheaths compressed and somewhat hairy; leaf blade long and narrow, both surfaces being smooth, as a rule, although the upper side is occasionally rough and thinly hairy; spikes five to seven, widely spreading, arranged at the apex of the stem in the manner of the fingers of the hand (digitately), often with one or two branchlets below the apex, two to four inches long, greenish; spikelets three to six-flowered; glumes pointless; terminal flower a mere rudiment; seeds inclosed within a thin, loose pericarp; blooms from June to October. Found on both waste and cultivated ground, and although an introduced grass, has been naturalized in the South and in the East.

Southern Spear Grass (Eragrostis pilosa, (L.) Beauv.). -An annual, growing five to eighteen inches tall, with erect or ascending stem, diffusely branched near the base; sheaths somewhat bearded at the throat, otherwise smooth; leaves narrow, flat and smooth, but folding back on the midrib when dry; panicle elongated, three to twelve inches long, widely spreading primary branches very loose, solitary, or two or three together; spikelets narrow, lanceolate, at length becoming linear, three to fifteen-flowered, mostly much shorter than their hairy pedicels, although sometimes exceeding them in length; glumes all ovate and acute, flowering ones three-nerved; grain long; blooms from June to October. A common roadside weed in all parts of the Mississippi valley, occurring most frequently in sandy, sterile ground, but found also on railroad embankments and especially abundant in flood plains of streams.

Candy Grass (Eragrostis megastachya, (Koeler) Link). -A rather showy, much-branched annual with erect, or ascending stems, six inches to three feet high; sheaths smooth but hairy at the throat; ligules (projections from the upper part of the sheath) mere fringes of short hairs; 
leaf blade flat, three to ten inches long, rather rough on the upper surface; panicle elliptical or oblong, branches usually spreading; spikelets three to ten inches long, seven to forty-flowered, becoming whitish when old; flowering glumes very prominently nerved and rough on the keel; emits an unpleasant odor; blooms from June to October. A weedy grass, common in fields and gardens across the continent.

Wire Grass (Poa compressa, L.).--Sometimes called English blue grass, a pale, slender, but rather rigid, perennial, with a much flattened stem, six to twenty inches high, ascending from a more or less creeping rootstock; dense narrow panicles somewhat one-sided, one to three inches long, short branches mostly in pairs; pedicels shorter than the spikelets, which are lanceolate, five to nine-flowered and flattened; blooms from June to September. A native of Europe, but extensively naturalized in this country; found in nearly all parts of the North, growing in dry, sterile places and waste lands; an excellent forage plant, but yields less than blue grass.

Cheat or Chess (Bromus secalinus, L.).-An erect annual growing from two to three feet tall; generally smooth, occasionally pubescent at the nodes; sheath striate, usually smooth; rather broadly linear leaf blade from six to twelve inches long, smooth beneath and more or less rough or pilose on the upper surface; flowers arranged in panicles, from four to eight inches long, erect, the more or less compound branches spreading even in fruit; spikelets from six to ten lines long, and six to twelve-flowered, drooping in fruit; first empty glume three to five; second, seven-nerved; flowering glumes obscurely seven-nerved, smooth or minutely downy along the margins and near the apex, becoming cylindrical in fruit; blooms in July and August. A well-known weed of grain fields, found in all parts of the wheat-growing sections of the country. 
soft Chess (Bromus hordeaceus, L.).-An erect, usually slender, pubescent annual, growing one to three feet high, with flat leaves and contracted panicles, which are one to three inches long; the three to eight-flowered spikelets are one-half to one inch long, with pubescent glumes; flowering glumes obtuse and with awns somewhat shorter than the glumes; blooms from May to August. Introduced and found along railroads, and in the streets of cities, and in fields and waste places in the North; nearly worthless as a forage plant.

Downy Brome Grass (Bromus tectorum, L.).-A slender, erect, leafy annual seven to twenty-five inches high, with narrow, softly pubescent leaves and open, nodding panicles, three to seven inches long; spikelets each five to eight-flowered, with unequal, acuminate-pointed, hairy, empty glumes, and rough or hairy glumes, four to six lines long; awns six to eight lines long; blooming period from June to August. First introduced into the United States from Europe, and is without forage value; while not greatly troublesome in Iowa or eastward, it has become a serious pest farther west in Utah and Colorado.

Poison Darnel (Lolium temulentum, L.).-An annual with a smooth, stout stem from two to three feet tall; rough sheaths and a spike from six to twelve inches long; spikelets five to seven-flowered, the sharp-pointed empty glumes as long as the spikelets; flowering glumes turgid, awned or awnless, and both shorter and broader than in common darnel (L. perenie); blooms from June to August; also called bearded darnel. Found in waste places and cultivated grounds in the wheat-growing sections of the country and Canada.

Couch Grass or Quack Grass (Agropyron repens, (L.) Beauv.).-An introduced grass already becoming troublesome in Iowa; culms one to three feet high, arising from an extensively creeping, jointed rootstock; sheaths usually smooth; leaves from four to twelve inches long, 


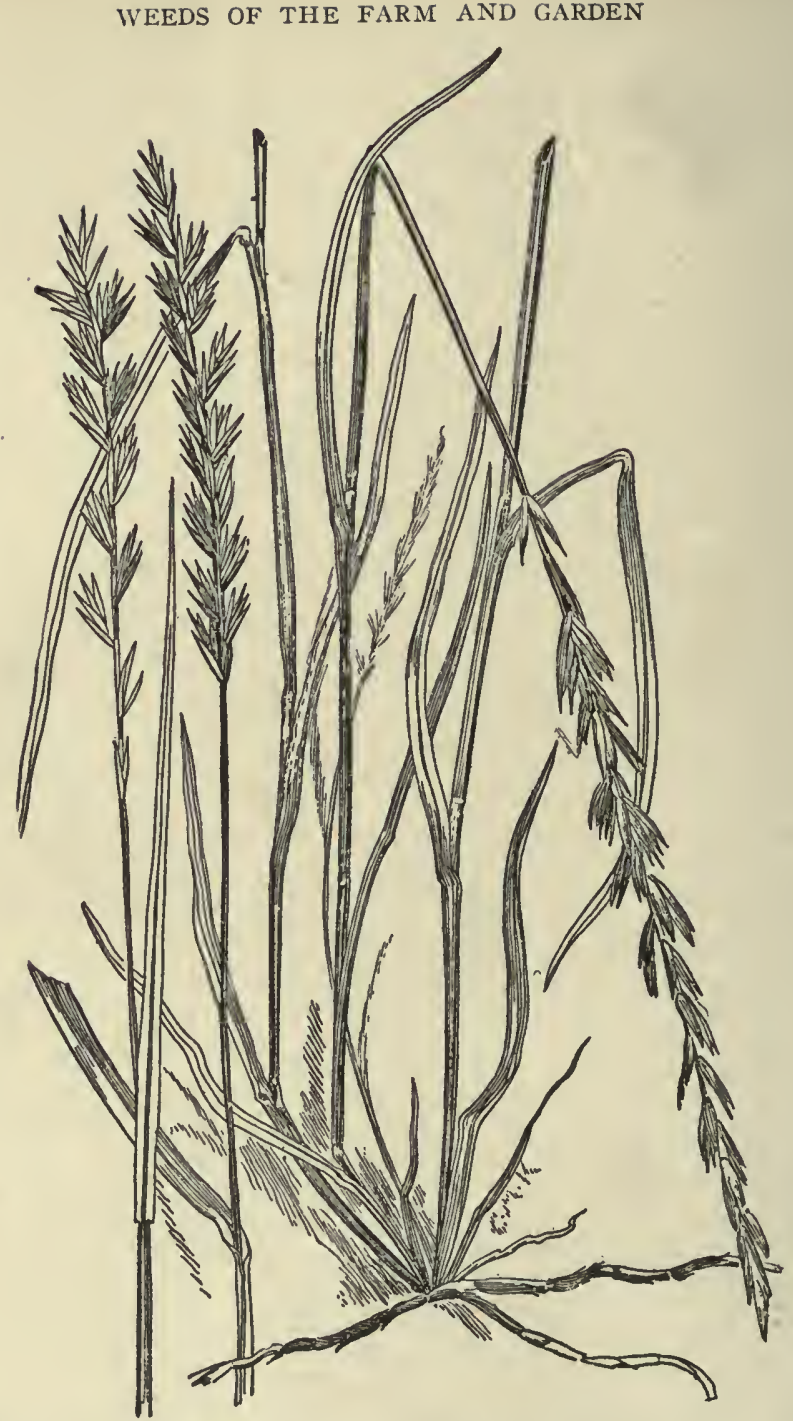

Fig. 93. Quack grass or couch grass (Agropyron repens). The running "roots" (rhizomes). 
smooth, scabrous or somewhat downy above; erect spikes from three to ten inches long, bearing four to eightflowered spikelets; empty glumes from five to sevennerved, sometimes notched and short-awned or acute; flowering glume nerved near the apex, awnless or shortawned. Blooming period from August to October. This grass has become naturalized on lawns and cultivated grounds and is a very common wayside pest.

Little Barley (Hordeum pusillum, Nutt.).-An annual four to ten inches tall, with stems more or less jointed at the lower nodes, the uppermost being often inflated, so as to inclose the base of the spike; leaf blade from one to three inches long, usually slightly pubescent on the lower surface; spikes narrow and from one to three inches long; empty glumes rigid, the four internal glumes of each group being dilated above the base, those at the central spikelet sublanceolate, all awn-pointed; outer glumes of the imperfect, lateral spikelets bristly; flowering glumes of central spikelet awned, and florets of the lateral glumes awnless. The flowers appear from April to August. This plant has been introduced into the southern part of Iowa.

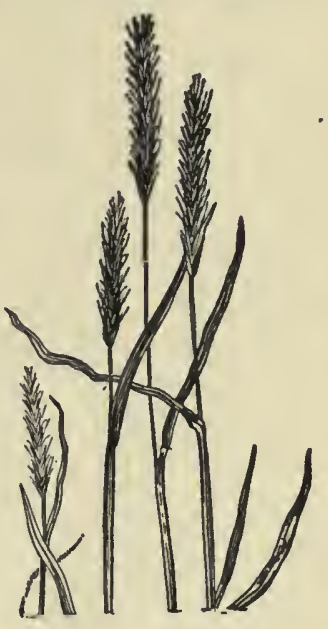

Fig. 94. Little barley (Hordeum pusillum).

Squirrel-tail Grass (Hordeum jubatum, L.).-An annual or winter annual, from six inches to two feet high with fibrous roots, forming solid bunches with leaves not unlike those of blue grass except in being paler; flowers appear in spikes two to four inches long, pale green or purplish; flowers with long awns which give it a bristly appearance; when mature, spikes break into joints; blooming period from June to August. Plant is propa- 


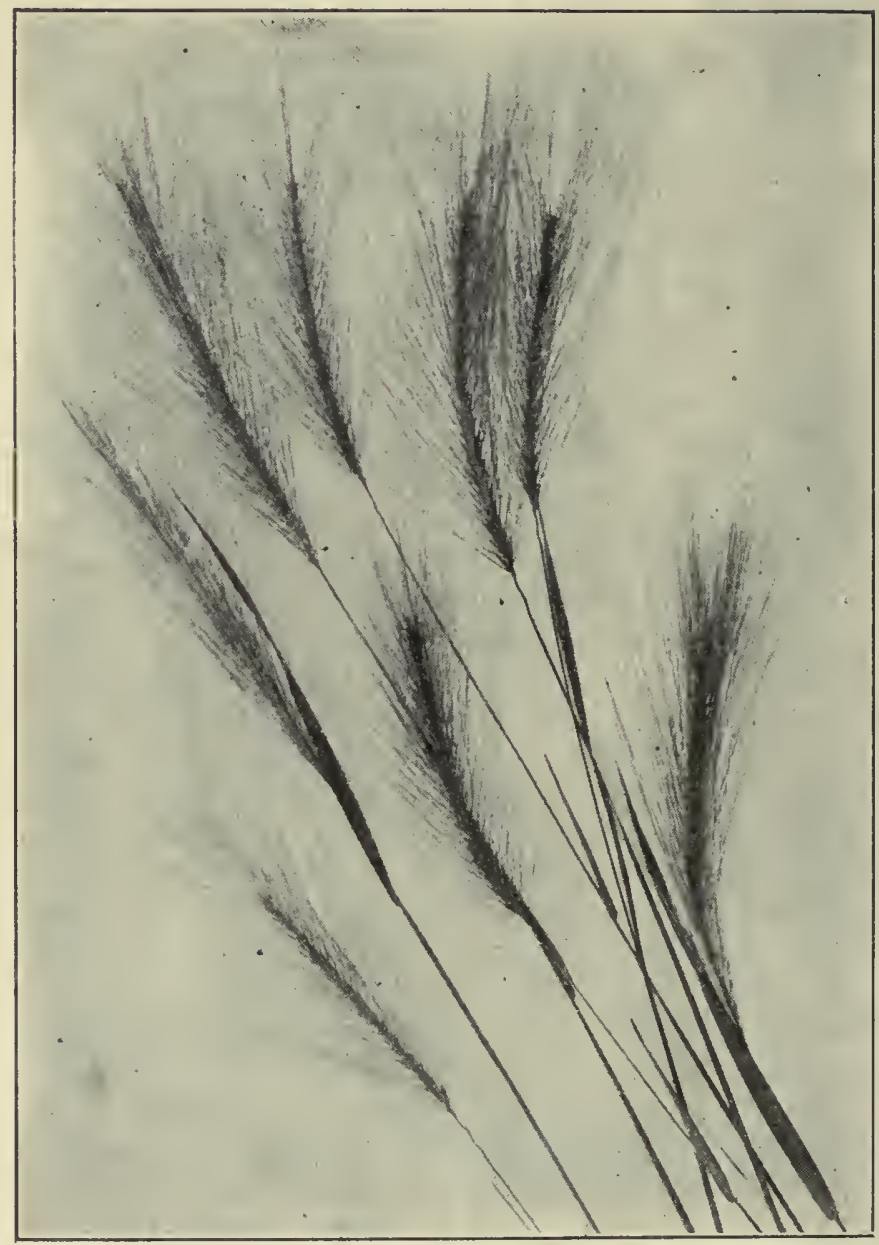

Fig. 94a. Common wild barley (Hordeum Jubatum). (Photograph, Miss Charlotte M. King.) 
gated chiefly by means of seed, from 300 to 2,500 seeds sometimes being produced by a single cluster of plants which have started from a single seed. Seeds are easily carried by the wind and by animals. Found abundantly in meadows and pastures, especially along roadsides in all parts of the West from the Great Lakes to the Pacific, and particularly obnoxious because the seeds and small pieces of the plant sometimes cause serious injury to stock by making their way into the gums and jaws and between the teeth, thus causing inflammation and the formation of pus.

Other species of wild barley are abundant in the United States. The $H$. secalinum is a very troublesome weed in Utah and the Pacific coast. It is much like the little barley. Another form, much like squirrel-tail, but with more slender spikes, is common from Utah to Montana and Wyoming, the $H$. caespitosum.

Sedge Family (Cyperaceae).-Grasslike or rushlike herbs, with fibrous roots, generally solid stems, which are either round, triangular or flattened; leaves with closed sheaths; flowers in spikes, chiefly with three stamens; styles two, three or rarely undivided; fruit an achene; ovary one-celled with a single erect ovule.

Northern Nut Grass (Cyperus csculentus, L.).-A grasslike plant, but distinguished from the true grasses by its triangular stems; when young, leafy at the base, later the leaves terminate the stem; flowers arranged in spikes, each consisting of numerous spikelets, which bear from twelve to thirty light chestnut or straw-colored flowers; scales of the spikelets rough margined; achene longer than broad. Plant spreads extensively by its underground nutlike tubers and, in rainy seasons especially, is in evidence everywhere in the state, its yellow color making patches of it easily visible at a distance; most troublesome in early spring; common in low grounds.

Southern Nut Grass (Cyperis rotundus, L.).-A long- 
leaved, persistent perennial, bearing scaly, tuberous, root bearing rootstocks, with a stout culm; leaves about onefourth inch wide with a cluster near the top having the appearance of an umbel, the leaves of which number three to eight; flowers borne in spikes consisting of numerous spikelets, each from twelve to forty-flowered; stems triangular; scales dark purple; seed three-angled.

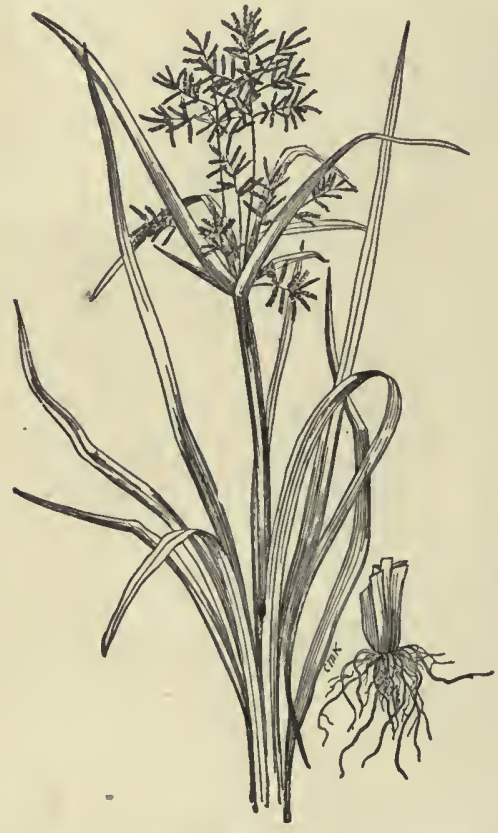

Common in places from Virginia to Florida and Texas; also occurs in the old world and is widely distributed in the tropics.

Rush (Scirpus atrovirens, Muhl.).-A stout perennial, two to four feet high, with pale green leaves, the margins scabrous, upper 1 e a ves whorled; spikelets dull greenish, or brown, ovoid ; bristles strongly barbed, nearly straight; fruit crowded, in scant, irregular clusters. Common in low grounds, a long streams from New England to Saskatchewan, Nebraska and Missouri. It is also said to be a

Fig. 95. Northern nut grass (Cyperus troublesome weed in esculentus).

Minnesota. S. validus is the common bulrush of our streams and ponds.

Rush Family (Juncaceae).-Grasslike herbs; inconspicuous, regular flowers in paniculate or corymbose clusters; perianth of six similar glumaceous parts, rarely four to five cleft; stamens three to six; pistil one-celled 
or three-celled with many ovules. Few genera, with about 200 species widely distributed.

Slender Rush (Juncus tcuuis, Willd.).-A leafy perennial with wiry stems eight to eighteen inches high; leaves flat or channeled; flowers in panicles shorter than the involucral leaves; flowers green; sepals lanceolate, acute, spreading in fruit; capsules green; seeds small, minutely ribbed; common in eastern North America, especially in beaten paths.

Lily Family (Liliaccac).-Herbs or rarely woody plants with regular, symmetrical flowers, perianth not glumaceous, of three sepals and three petals; six stamens; ovary three-celled; fruit a pod or berry; embryo inclosed in the hard albumen. An order of about 1,600 species containing several ornamental plants, such as the lily, lily of the valley. and yucca; some medicinal plants like squill, aloe, false hellebore; several poisonous plants, like death camas and colclicum and a number of weeds.

Meadow Garlic (Allium canadcnse, Kalm).-Bulb ovoid; outer coat fibrous, reticulated; scape one foot or more high; leaves narrowly linear, slightly convex beneath; flowers in umbels often

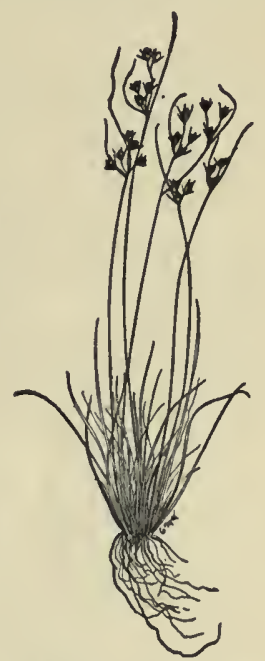

Fig. 96. Slender rush (Juncus tenuis). bulbiferous, white or pinkish ; segments of perianth lanceolate, equal or exceeding the stamens. Common in moist meadows; said to flavor milk when fed to dairy cows.

Wild Garlic (Allium vincalc, L.).-Bulb ovoid; scape slender; leaves several, terete and hollow, slender, channeled above; flowers in erect umbels, but often replaced with small bulblets, which are tipped with an appendage; flowers green or purple. Naturalized from Europe, common in fields eastward, often giving a bad flavor to wheat flour. 
Star-of-Bethlehem (Ornithogalum umbellatum, L.).-Plants growing in tufts; bulbs ovoid; scape slender, four to nine inches high; flowers corymbose, opening in sunshine; perianth of six white, spreading segments, oblong, lanceolate, white above, greenish beneath. Naturalized from Europe, common in lawns and roadsides, eastward and south to Kentucky.

Pepper Family (Piperaceae).-Perennial herbs with alternate, entire broad leaves; flowers small, incomplete, in bracted spikes; calyx and corolla wanting; stamens six to eight, free from the ovary; ovary with few straight ovules; seed globose or ovoid; endosperm mealy, copious; embryo small; fruit a capsule or berrylike. A small order of four species. In the South represented by the lizard's tail (Saururus cermuus), which occurs in swamps and shallow water.

Yerba Mansa (Anemopsis californica, Hook.).-An acrid, perennial herb with thick, strongly pungent, astringent and aromatic creeping rootstock and jointed or scapelike stem, one-half to one and one-half feet high, with a broadly ovate leaf, clasping above the middle, and a fascicle of one to three small, petioled leaves in the axil; radical leaves thick, elliptical oblong, rounded above, more or less narrowed toward the cordate base, two to six inches long, somewhat ciliate; petioles about equaling or shorter than the blade, dilated and sheathing at the very base; bracts of involucre white, five to eight, persistent, rounded and oblong; flowers in a close conical spike, each flower subtended by a white bract; stamens six to eight, short filaments adnate to base; ovary sunk in rachis of spike, one-celled, of three to four carpels, with as many spreading stigmas and parietal placentæ; seeds rounded, punctulate. In moist saline localities from the Sacramento to Southern California and eastward to Southern Utah and the Rio Grande.

Nettle Family (Urticaceae).-Herbs, shrubs or trees 
with stipules; flowers monoecious or dioecious, rarely perfect; calyx free from the one to two-celled ovary which forms the one-seeded fruit; stamens as miny as the lobes of the calyx or sometimes fewer; opposite; seeds albuminous or ex-albuminous; when albuminous. the radical points upward; cotyledons broad.

Hemp (Cannabis sativa, L.).-A stout, rough, dioecious annual; leaves digitate, five to seven, linear, lanceolaie; leaflets coarsely toothed; inner bark of tough fibers; staminate flowers in axillary, compound racemes, pistillate flowers in erect spikes, consisting of the calyx, with a single sepal folded around the ovary; fruit, an achene; seed oily, embryo straight. Widely distributed throughout eastern North America, north of the Gulf States, and the Rocky Mountains.

Common Slender Nettle ( $U r-$ tica gracilis, Ait.).-A perennial herb armed with stinging hairs ; stem slender, two to six feet high; leaves ovate-lanceolate, pointed serrate, three to fivenerved from a somewhat

rounded base, nearly smooth, Fig: 97. Common nettle (Urpetioles somewhat bristly;

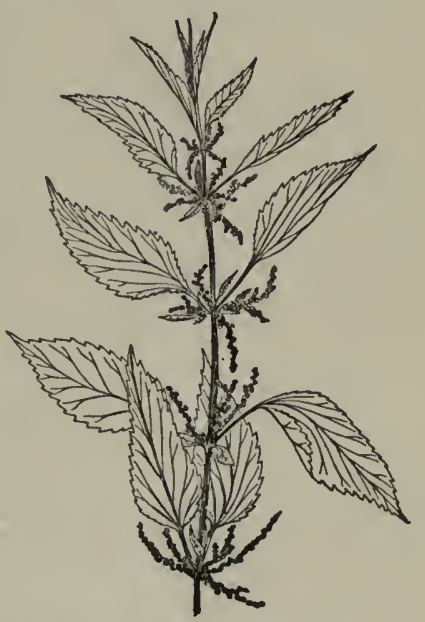
flowers small, numerous, dioecious, or some with staminate and pistillate flower clusters; calyx deeply fourparted; stamens four, stellate with calyx; inclosed by it. Common along fences and waste places in eastern North America to Kansas, and the Rocky Mountains to Colorado.

Stinging Nettle (Urtica dioica, L.).--Like the preceding, stem beset with bristly, stinging hairs; two to three feet 
high, leaves ovate, deeply serrate, downy underneath; flower cluster large, otherwise like the preceding. In waste places from New England to Missouri.

Small Nettle (Urtica urens, L.).-An annual, but slightly urticating, eight to twelve inches high; leaves elliptical, glabrous, shorter than the petiole; pistillate and staminate flowers in the same cluster. In waste places near dwellings from New England to Texas.

Western Nettle (Urtica holosericea, Nutt.).-A tall, stout, more or less stinging perennial, finely and densely tomentose; leaves thick, oblong to obovate-lanceolate, on a short petiole, tomentose, especially the lower surface of the leaf; staminate flowers in loose panicles; pistillate flowers in denser and shorter panicles. Common in Utah and westward; strongly urticating.

Buckwheat Family (Polygonaceac).-Herbs, shrubs, or trees, with alternate or sometimes opposite, entire leaves, stems with swollen joints; stipules in the form of sheaths; flowers small, regular, perfect, dioecious, monoecious or polygamous; petals none; sepals often colored, petal-like, two to six-cleft or two to six-parted; stamens two to nine; ovary one-celled, bearing two to three styles or stigmas; fruit usually an achene, compound or three or four-angled or winged; embryo curved or straight. About 800 species of wide distribution. Contains the buckwheat, rhubarb, docks, etc.

Curled Dock (Rumex crispus, L.).-A smooth perennial, growing from three to four feet tall, with a long root; leaves lanceolate, acute, margins wavy and curled; bases of lower leaves somewhat truncate or inclined to be heart-shaped; flowers collected in dense whorls, which become extended or prolonged into racemes entirely leafless above or with few small leaves below; flower with eight sepals, the three outer herhaceous and leaflike, the three inner larger, somewhat curled and forming, after flowering, the valves of the fruit; fruit three-angled, each 
valve bearing a seed. Found along roadsides and in meadows across the continent, and in Europe.

Pale Dock or Peach-leaved Dock (Rumex altissimus, L.).-Closely allied to preceding; from two to six feet tall; leaves longer than those of $R$. crispus, oblong, lanceolate, acute, rather thick, and without the wavy curled margin of curled dock; flowering racemes long, spikelike, petioled, and nearly leafless; one of the three valves in fruit bears a conspicuous grain.

White Dock (Rumex mexicanus, Meisn.). - Lower growing than either of the preceding, being not more than three feet in height; white root; narrow lanceolate or linear leaves, the lowest sometimes oblong; flowers in crowded whorls, the pedicel much shorter than the fruiting calyx; one, two, or sometimes, all three of the valves of the achene bear each a conspicuous grain. Low grounds from New England to California.

Patience Dock (Rumex Patientia, L.).-A tall, glabrous perennial; lower leaves long petioled; dense fruiting panicles. In low and moist grounds from New England to Utah. The broad leaved

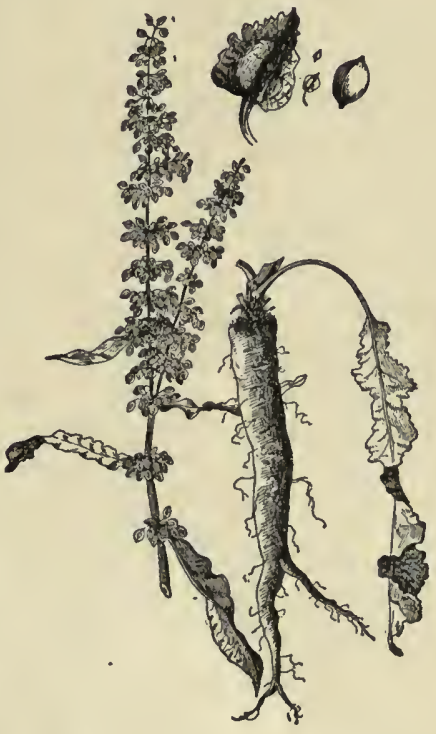

Fig. 97a. Sour dock (Rumex crispus). A troublesome weed in fields, meadows and along roadsides. (Harrison and Lockhead.) or bitter dock ( $R$. obtusifolius, L.) is a glabrous perennial with erect stem; lower leaves oblong-lanceolate; open panicle; wings of fruit with few spreading, spiny teeth. Naturalized from Europe. 
Sheep Sorrel (Rumex acetosella, L.).-Sheep sorrel is closely allied to the docks and is quite prevalent in many parts of the North. It is a low, smooth annual or perennial, usually the latter, growing from six to twelve inches tall, and coming from a horizontal, creeping root; stem erect; leaves narrow, eared, lanceolate (the upper linear); flowers terminate, jointed stalks or stems, and are small, with green calyx and exserted stamens. Common in pastures and clover fields, the seed being sometimes introduced as an impurity in clover seed. The plant is also spread by means of underground roots and stems.

There is a widely spread belief that the soil in which this plant occurs is sour, that is, is lacking in lime, and that the addition of lime will exterminate the weed; but this opinion is erroneous, since sheep sorrel is quite as common upon the calcareous soils of Wisconsin and eastern Minnesota as it is on the dry, sterile hills of Massachusetts and Iowa.

Knotweed or Dooryard Weed (Polygonum aviculare, L.).-A slender annual, or more commonly, a perennial, with a prostrate or somewhat ascending stem from six to twelve inches long; leaves ovate, lanceolate or oblanceolate with a short petiole, smooth or sparingly hairy; stipules, called ochreæ, silvery, two-parted, later cut or fringed; flowers in axillary racemes from one to five; sepals green with five lobes; style short, three divided; achene striated, three-angled. A common weed throughout eastern North America to the Pacific coast. Introduced from Europe. Found in both Europe and Asia.

Related to $P$. aviculare, is the larger knotweed ( $P$. erectum), a glabrous annual, with erect stem from eight to fourteen inches high ; leaves oval or oblong, nearly sessile on short petioles; flowers one to two in the axils of the leaves; stamens six, occasionally five; style short; achene three-angled. Native from New England to On- 
tario and Manitoba, extending south to Tennessee and Arkansas, and west to the Great Basin in Utah.

Another ally of these is the bushy knotweed ( $P$. ramossissimum), an annual with bright or yellowish green, smooth leaves, erect or ascending stem, generally branched, from two to three feet high; flowers several in axillary clusters, greenish, pedicellate, achenes exserted, shining, three-angled, reticulate, dull in color. Common in Manitoba, Dakotas, Maine and New Jersey to Missouri, New Mexico and California.

Muhlenberg's Smartweed or Marsh Smartweed (Polygonum Muhlenbergii (Meisn.) Watson).-A decumbent

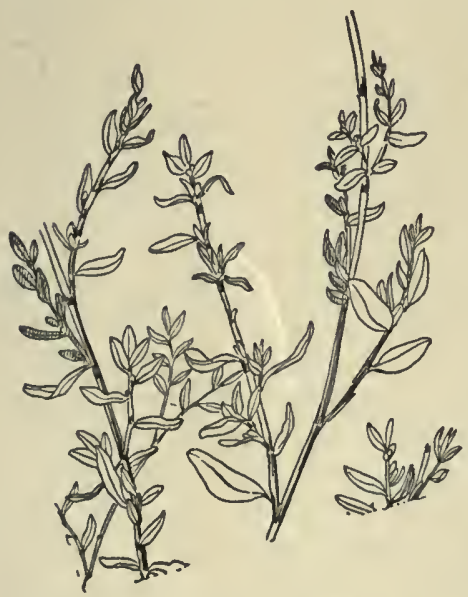

Fig. 98. Dooryard weed (Polygonum aviculare). or nearly erect perennial, with long underground rootstocks; grows from one to three feet tall; flowers bright rose color, arranged in spikes from one to three inches long. Extremely common in low grounds, especially in old lake beds and ponds, which, when drained and planted with corn, often grow up to this weed, in the North.

Lady's Thumb (Polygonum Persicaria, L.).- A nearly smooth annual or biennial from twelve to eighteen inches high; leaves lanceolate, pointed and somewhat rough, often marked with a dark triangular spot near the middle; spikes differ from those on $P$. pennsylvanicum, in being on peduncles that are free from glands; spikes ovoid or oblong, dense, and erect; calyx colored; stamens generally six; styles two to three-cleft; achene smooth and 
shining, sometimes triangular. Originally from Europe but becoming very common in waste places.

Water Pepper (P. Hydropiper) is much like P. Persicaria, but more slender and often decumbent. It has greenish flowers and slender, nodding spikes; achenes dull in color and the whole plant more or less acrid. Another water pepper or smartweed ( $P$. hydropiperoides) is a

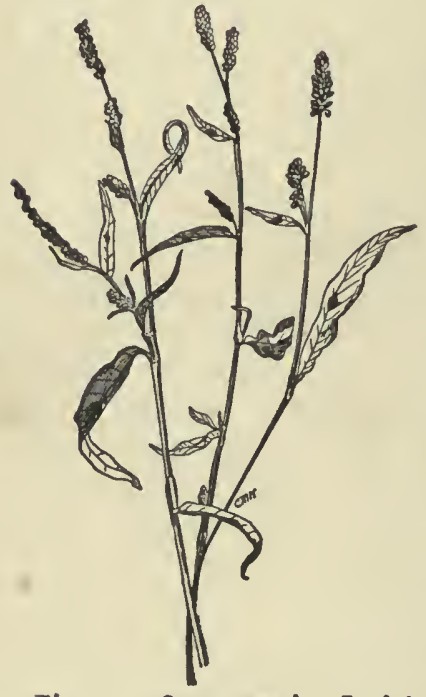

Fig. 99. Smartweed. Lady's thumb (Polygonum Persicaria). perennial, not acrid; with leaves narrowly lanceolate or oblong and small flesh-colored flowers in erect slender spikes; smooth achenes sharply triangular.

Common Bindweed or Wild Buckwheat (Polygomum Convolvulus, L.).-A smooth or scurfy annual with a trailing or twining stem, two to four feet long with naked sheaths; leaves hastate or pointed; flowers in axillary clusters or in interrupted racemes; greenish with slender pedicels; calyx five, rarely six-parted; stamens eight; style nearly entire, stigmas three; achene three-angled, dull blackish, obovoid. Common in waste places and especially in grain fields of the North throughout North America. Native also to Asia and Europe, probably introduced early with grains. Very commonly found with wheat and oats seed in the North.

Pennsylvania Smartweed (Polygonum pennsylvanicum, L.).-This smartweed, sometimes called heart's ease, is common in low grounds and corn fields. Peduncles of flowers with glands.

Slender Smartweed (Polygonum lapathifolium, L.).- 
This is an annual, from one to four feet high, with smooth stem and whitish flowers. It is common in low grounds.

Goosefoot Family (Chenopodiaceae).-Herbs or occa-

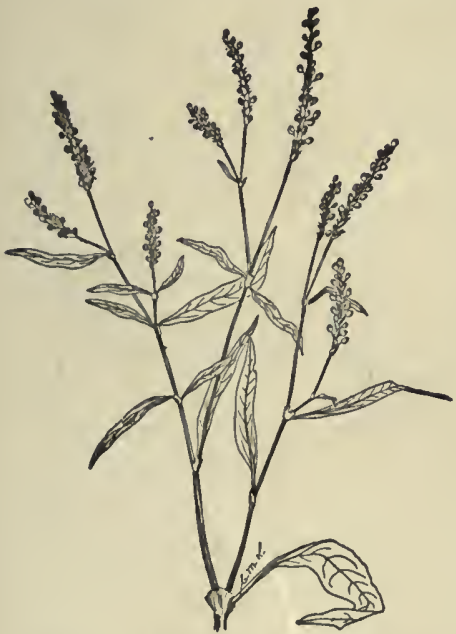

Fig. 1oo. Pennsylvania smartweed (Polygonum pennsylvanicum). sionally shrubs, frequently succulent; leaves mostly alternate without stipules; flowers small, greenish, regular or slightly irregular; clustered or solitary in the axils of the leaves; calyx two to five lobed or two to five-parted or (rarely) a single sepal; stamens as many as the lobes or occasionally fewer ; ovary onecelled, ovule solitary; fruit utricle with a thin membrane (pericarp) or rarely an achene. A small order of about 500 species of wide distribution. Many are troublesome weeds. Spinach, beet, greasewood, sea blite, white sage, and sugar beet belong to this order.

Winged Pigweed or Western Tumbleweed (Cycloloma atriplicifolium, (Spreng.) Coult.).-An annual, diffusely branched, smooth or occasionally pubescent, alternately petioled, occasionally petioled, flowers in panicles and interrupted spikes; calyx five-lobed, stamens five, styles three, seed horizontal, flat, coats crustaceous; the winged calyx incloses the fruit, the lobes not entirely covering the summit of the utricle. Common in the sandhills west of

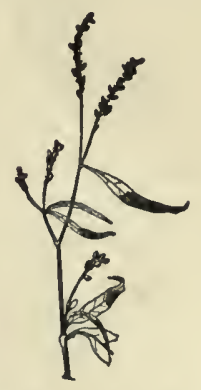

Fig. ror. Slender smartweed (Polygonum la. pathifolium). 
the Missouri River, and also eastward around the great lakes. Plant grows in spherical form and at maturity separates from the roots close to the surface of the ground. A well-known western tumbleweed.

Kochia or Mexican Fireweed (Kochia scoparia, (L.) Schrad.).-An annual, erect, puberulent or glabrate herb; leaves lanceolate to linear, ciliate; flowers sessile in the axils of the upper leaves forming short, dense, bracted

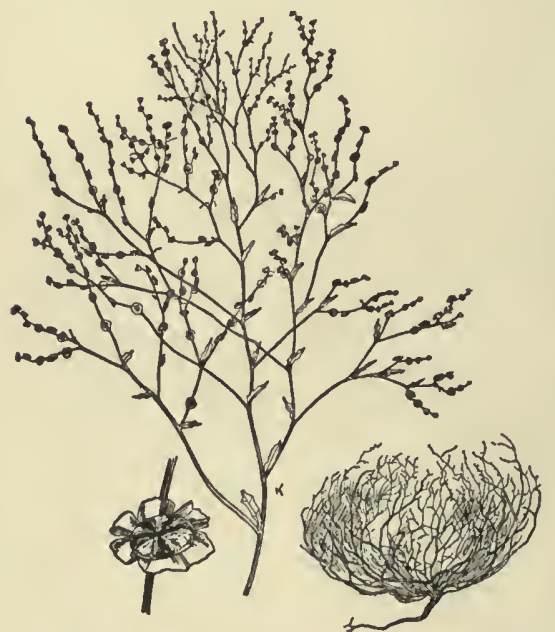

Fig. 102. Winged pigweed (Cycloma atriplicifolium). spikes; fruiting calyx segments each with a short triangular horizontal wing. In waste places commonly cultivated and now a frequent escape especially in the West.

Mexican Tea (Chenopodium ambrosioides, L.).- A smoothish aromatic an $\mathrm{nual}$; leaves short petioled, oblong or lanceolate, repand toothed or nearly entire; spikes densely flow e red, leafy; fruit inclosed in the calyx. Common especially southward in waste places, streets, and roadsides.

Fremont's Goosefoot (Chenopodium Fremontii, S. Wat.).-A light green annual with erect branched stems; leaves thin, broadly triangular, hastate, sinuate dentate; the upper entire, base truncate or narrowed, petioled; spikes, slender divisions of perianth nearly inclosing the utricle; seed shining. Common from South Dakota to Colorado, Utah, New Mexico, and Nevada to Montana. 
Other troublesome species are maple-leaved goosefoot (Chenopodium hybridum), bright green, thin leaves, somewhat triangular, heart shaped, and taper pointed. A tall and coarse weed.

Goosefoot or Lamb's Quarter (Chenopodium album, L.).-An erect annual growing from one to four feet high; young plants generally mealy and furnish a very good substitute for asparagus; old plants smooth; leaves rhombic-ovate to lanceolate, upper leaves sometimes linear; flowers quite inconspicuous, produced in dense, clustered panicles; seeds small, black and frequently inclosed by a thin membrane called the utricle. Abundant in all parts of the Mississippi Valley and seen as far West as the coast. Native to Europe, and common in eastern North America as well as in Europe and Asia.

Orach (Atriplex patula, L.)-Erect or prostrate, glabrous. Leaves narrowly

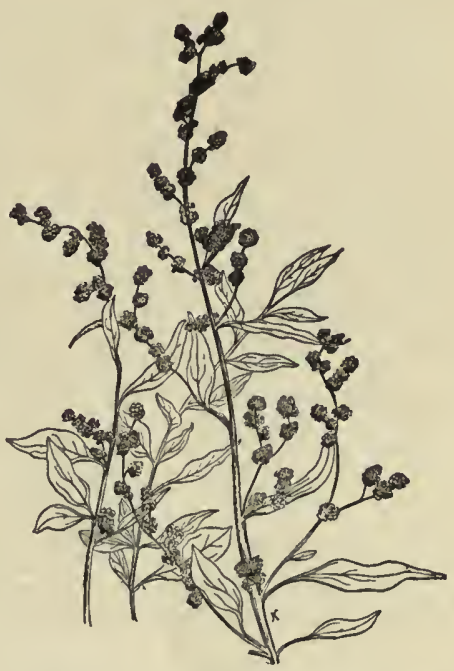

Fig. 103. Goosefoot or lamb's quarter (Chenopodium album). lanceolate hastate, the lower entire or nearly so, petioled, the upper leaves linear; flowers in slender spikes. Fruiting bracts ovate-triangular, entire or toothed. From northeastern United States to Missouri and British Columbia.

Russian Thistle (Salsola Kali, L., var. tenuifolia, G. W. F. Mey.).-An herbaceous, smooth or slightly pubescent annual, very diffusely branched from the base and spherical in the mature form, which is from one to three and one-half feet tall; leaves fleshy, succulent and arranged 
alternately on the stem, one or two inches long, pointed in the older plants, on which the leaves are persistent, flowers inconspicuous, solitary and sessile; stem and branches red; calyx five-lobed, persistent inclosing the dry fruit, usually red in color. Sometimes called tumbleweed from

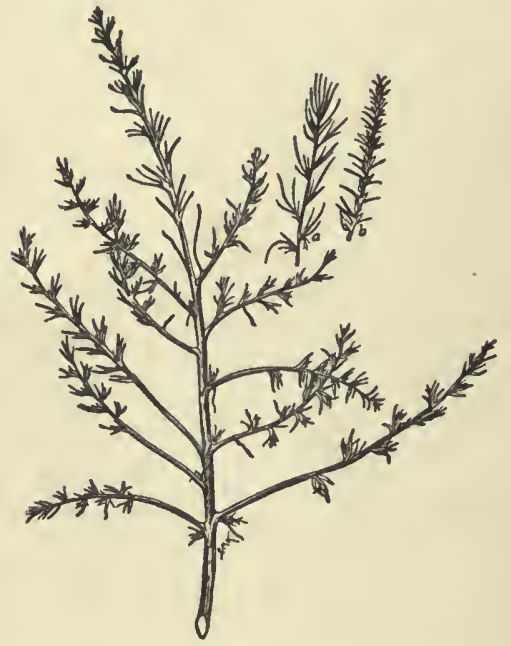

Fig. 104. Russian thistle (Salsola Kali, var. tenuifolia). its habit of rolling over the prairies when dry. By this means the seed is scattered. An introduced weed from northern Europe, now found in the Mississippi Valley, New York, and the Western States.

Amaranth Family (Amaranthaceae). Herbs with inconspicuous greenish flowers, imbricated with persistent bracts; the flowers usually in terminal spikes or axillary heads; pistils none, calyx herbaceous or membranous; stems one to five, mostly opposite; ovule one-celled, ovary solitary; fruit a utricle, one-seeded, seed small, minute.

Green Pig Weed (Amaranthus retroflexus, L.).-A coarse, persistent herb more or less pubescent; leaves dull green, long petioled, ovate or rhombic-ovate; spikes thick and crowded; bracts awn-pointed and rigid, exceeding the scarious tipped sepals, stamens five; seed black and shiny. This weed is common throughout North America, except far northward.

The Amaranthus hybridus is similar to the preceding but smoother and deeper green; spines and linear-cylindrical 
bracts subulate, much longer than the cuspidate sepals. Native to tropical America; not as abundant as the preceding, in waste places. The spiny amaranth (Amaranthus spinosus) has a stout stem with ovate or rhombic ovate leaves, with a pair of rigid stipular spines at each node; flowers in capitate, axillary clusters and monoecious. The tumbleweed (Amaranthus albus) is smooth and pale green, stems erect or ascending, branching, sepals acuminate, bracts pungently pointed, seeds small. Common throughout eastern North America. The prostrate pigweed (Amaranthus blitoides) is like the last, but prostrate; it has contracted spikelets with obtuse or acute sepals. A common weed in wet ground along roadsides.

Water Hemp (Acnida tuberculata, Moq.).-Tall, erect herb with lanceolate leaves, usually acute or acutish; flowers dioecious; sepals of the staminate flowers lanceolate; pistillate flowers clustered in more or less dense, naked, or leafy axil-

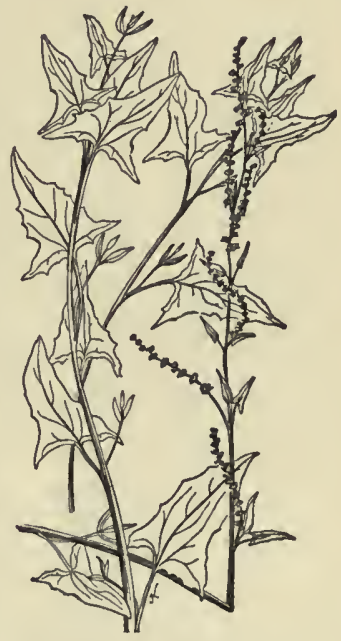

Fig. ro5. Orach (Atriplex patula, L.).

lary, or terminal spikes; seeds.smooth and shining. A very common weed in low grounds, especially in sandy soil.

Juba Bush (Iresine paniculata, (L.) Kuntze).-Closely related to the above, is a tall herb with opposite petioled leaves and small three-bracted white flowers produced in large terminal panicles, flowers very numerous, calyx of five sepals, pistillate, woolly, flowers white. Its distribution, from Ohio to Kansas, Texas to Florida.

Froelichia (Froclichia floridana, Moq.).-Very woolly, stem nearly leafless, one to three feet high, with annual root; lanceolate leaves, silky and downy beneath; flowers 
perfect, three-bracted, in nearly obovate spikes, calyx tubular, five-cleft, utricle indehiscent. Common in sandy soil, where it is sometimes a very troublesome weed; from southern Minnesota and Wisconsin to Nebraska and southward.

Pokeweed Family (Phytolaccaceae).-Generally herbs, a few of the tropical trees or shrubs with alternate entire leaves without stipules, perfect, regular, polygamous or monoecious flowers; calyx petal-like of four or five sepals or four to five-parted; stamens five to thirty alternate, with the segments of the calyx or sepals of the same number or more numerous; ovary several-celled; ovules solitary.

Pokeweed (Phytolacca decandra, L.).-A tall, stout, smooth perennial with an unpleasant odor, six to nine feet high; root large; leaves large petioled; flowers in terminal racemes; flowers of five rounded petal-like sepals; fruit a berry filled with a dark crimson juice. From New England states to Illinois and Texas. The large root of the plant poisonous.

Fig. 106. Prostrate pigweed (A maranthus blitoides).

Four O'clock Family (Nyctaginaceae).-Herbs or some tropical trees or shrubs; leaves generally opposite and entire, swollen joints; flowers regular in clusters, frequently subtended by an involucre; petals none, calyx inferior, corolla-like, tubular, four to five-lobed or four to five-toothed; stamens free, anthers two-celled; ovary onecelled and one-seeded, forming a kind of nut; embryo coiled around the mealy endosperm; cotyledons large; in Abronia, by abortion, a single cotyledon.

Wild Four O'clock or Umbrella Plant (Oxybaphus nyctagineus (Michx.) Sweet.).-A nearly smooth perennial with thick roots, repeatedly forked; leaves petioled, 
except the upper, broadly ovate to lanceolate or cordate, cuneate at the base; flowers in loose inflorescence; slender peduncles, smooth or slightly pubescent; fruit oblongobovate, rather acutely angled. Common in Illinois, to Minnesota, to Texas.

The western $O$. hirsutus is glandular hirsute; leaves lanceolate or linear-lanceolate. Western Iowa to Saskatchewan, Colorado to Texas. The O. linearis is tall and smooth; peduncles hirsute, with 1 inear leaves. Occurs from Iowa to Utah and Mexico.

Hogweed (Boerhaavia erecta, L.).-An annual herb with ascending stem, branched from base; swollen joints; leaves ovate or roundish, acute or mucronate, often more or less obcordate, whitened and minutely dot ted underneath;

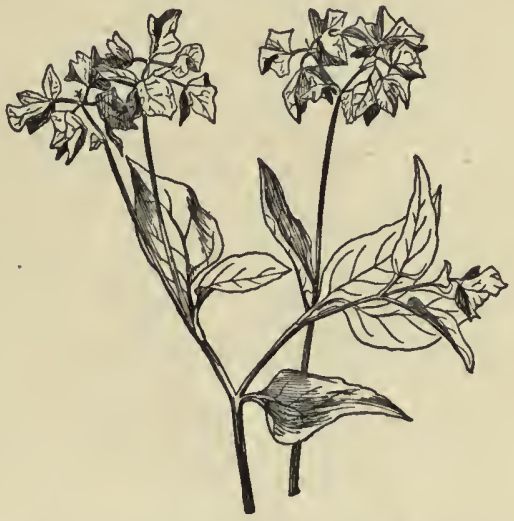

Fig. 107. Wild four o'clock or umbrella plant (Oxybaphus nyctagineus). flowers perfect without involucre; clusters three to fiveflowered in ample panicles; calyx tube cylindrical, fiveribbed, limb colored, funnel shaped, five-lobed. Common in southern states from South Carolina to Texas.

Pink Family (Caryophyllaceae).-Herbs with opposite, entire leaves, frequently swollen at the nodes; flowers perfect or rarely dioecious ; sepals four or five, persistent, separate or united with the calyx tube; petals of equal number, styles two to five, or rarely united into one; ovary usually one-celled, occasionally three to five-celled, ovules attached to a central column; seeds several or many; small coiled or curved embryo with a mealy albu- 
men. A large order, of about 70 genera and I,500 species, widely distributed, most abundant in the northern hemisphere. Many of the plants of this order are cultivated for ornamental purposes. Among these are the hardy pink (Dianthus barbatus), and the carnation (D. Caryophyllus). Many plants of this family are weedy, such as the larger mouse chickweed (Cerastium viscosum), a common eastern perennial with a clammy, hairy stem, and white petals. In the South the nodding mouse-ear chickweed ( $C$. nutans) is common in fields. This is an annual with clammy, hairy stems diffusely branched; flowers produced in loose, open clusters; pods nodding on the stalk from which arises the technical name.

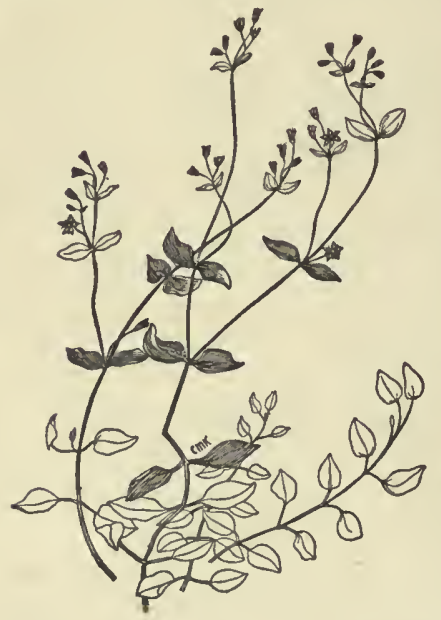

Fig. 108. Chickweed (Stellaria media, L.). lawns and, because of the great vitality of the plants and seeds, is difficult to eradicate. In Iowa, the blooming period lasts from March to December, seed being matured through all of this time. The stems form a net- 
work on the surface of the ground striking root at every joint, thus crowding out more desirable plants and the prostrate habit of the plant makes it difficult to cut it off by means of a lawn mower. The light seeds are readily scattered.

Evening Catchfly (Lychnis alba, Mill.).-A rather coarse hairy biennial, more or less viscid, one to two feet high; leaves oval, oblong, usually pointed, tapering at the base; flowers in loose panicles, rather large, white or pale pink, opening in the evening, usually dioecious; sepals, five, linear-lanceolate, calyx swelling as the capsule ripens; petals twocleft, seed black, rough and kidney shaped. Found in clover fields, common in Europe.

Ragged Robin, Cuckoo Flower (Lychnis Flos-cuculi, L.).-A short-lived perennial from one to two feet high, slightly downy below and viscid above; leaves lanceolate; flowers in loose panicles, red, pink, blue or white, scentless; calyx short, smooth; petals cut into four linear lobes, the two middle ones the longest; capsule nearly globu-

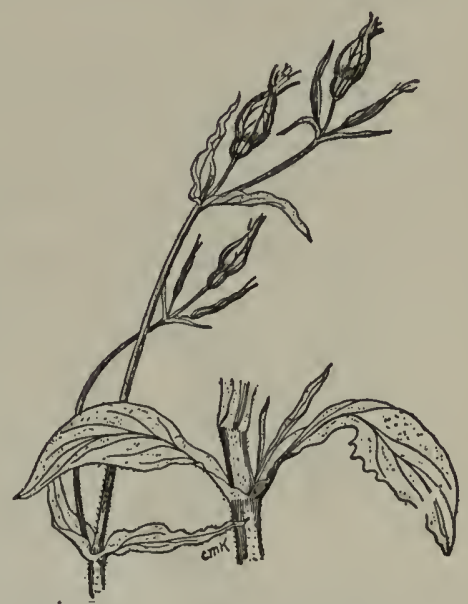

Fig. rog. Evening catchfly (Silene noctiflora). lar. In New England to Pennsylvania occurring also in clover fields. The white or bladder campion, ( $L$. alba) with globular or ovoid calyx, two-cleft, occurs in the East and is occasionally found in meadows.

The Sleepy Catchfly (Silene antirrhina, L.) with slender stems, joints glutinous, leaves lanceolate or linear, pink flowers, is a common weed in sandy fields in the Mississippi Valley, Colorado to Mexico. 
Night-flowering Catchfly (Silene noctiflora, L.).-A tall glandular pubescent plant with few large, white, fragrant flowers, opening at night. A weed in cultivated grounds.

Bladder Campion (Silene latifolia, (Mill.) B. and B.).A glaucous plant with opposite, ovate-lanceolate leaves; a globose, inflated calyx, petals two-cleft. Flowers white. Common in clover fields, Iowa and eastward.

Corn Cockle (Agrostemma Githago,

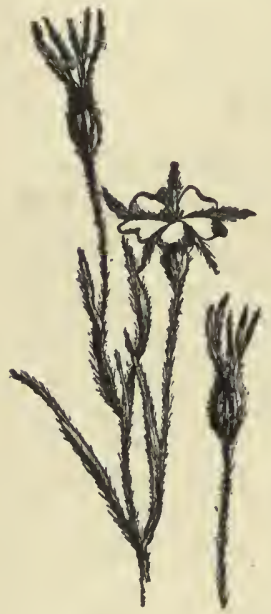

Fig. Iro. Corn cockle (Agrostemma Githago). (Ada Hayden, modified from Clark and Fletcher.) L.).-Tall, silky annual, or perennial; with linear leaves and purplish red flowers. A weed in grain fields and by roadsides.

Cowherb (Saponaria Vaccaria, L.).An annual, glabrous plant, with pale red flowers in clusters, and ovate-lanceolate leaves. A weed in grain fields.

Soapwort or Bouncing Bet (Saponaria officinalis, L.).-A coarse, smooth perennial; leaves smooth, ovate or elliptical, two to three inches long, three to five-ribbed, petioled; flowers large in dense, corymbose clusters; calyx tubular, petals pale pink, or nearly white, fragrant. A common escape eastward, Illinois, Iowa, Wisconsin, less common in the Rocky Mountains.

Purslane Family (Portulacaceae).Succulent-leaved herbs, with regular unsymmetrical flowers, two sepals and five petals; stamens numerous or few; ovary one-celled, in fruit becoming a pod with many or few seeds. A small order of about 150 species, mostly native to North America. A few of the species, like the moss rose (Portulaca grandiflora), are cultivated for ornament, and the common purslane is cultivated as a vegetable. 
Pusley, Purslane (Portulaca oleracea, L.).-A fleshy, prostrate, smooth annual, with scattered, obovate or wedge-shaped leaves; small sessile flowers with a twocleft calyx, and five small yellow flowers inserted on the calyx; stamens seven to twelve; style deeply five to sixparted; seeds small, finely rugose. Common everywhere on cultivated and waste grounds. Probably indigenous in the West and Southwest. Naturalized from Europe.

Crowfoot Family (Ranunculaceae).-Herbs or a few woody plants with acrid juice; flowers polypetalous or apetalous, regular or irregular; calyx free, often colored like the corolla; sepals three to fifteen, petals three to fifteen, or absent; stamens numerous, and pistils few or numerous, distinct; fruit a dry pod, berries or achene (seedlike); embryo minute, albumen present.

Cursed Crowfoot (Ranunculus sceleratus, L.).-A glabrous annual, root leaves three-lobed, rounded, lower stem, leaves three-parted, lobes cut and toothed, the upper leaves nearly

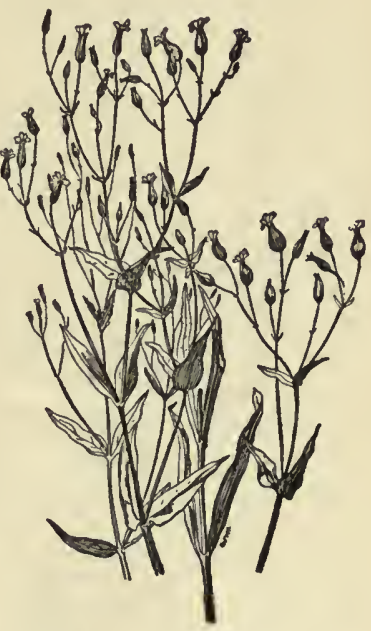

Fig. Irr. Cow herb(Saponaria Vaccaria). sessile; flowers small and numerous, petals pale yellow, scarcely longer than the calyx; carpels small, barely mucronate in oblong or cylindrical heads, juice of plant acrid. Common in wet soil eastward and in the North also in the Rocky Mountains, Colorado, and Utah.

Small-flowered Crowfoot (Ranunculus abortivus, L.).A smooth, glabrous, branching biennial, six inches to two feet high; root leaves round, heart-shaped or kidneyshaped, stem leaves three-parted or three-lobed, nearly 
sessile, lobes linear; flowers small, petals pale yellow; carpels orbicular with minute beak. A common weed in shady places, fields, and roadsides, especially eastern North America.

The tall buttercup ( $R$. acris), with hairy stem two to three feet high; three-divided leaves, large yellow flowers with rounded petals, longer than the calyx; plant with acrid juice. Common eastward. In the prairie region the $R$. septentrionalis with long runners, slim, smooth, or hairy plants; leaves three-divided, petals yellow. Common.

The Early Crowfoot ( $R$. fascicularis).-A low ascending plant with three-parted root leaves; yellow flowers and

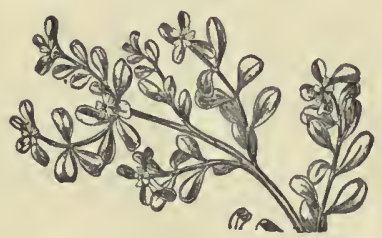

Fig. II2. Purslane (Portulaca oleracea). fascicled, tuberous roots. Common in clay hills in Minnesota, Ohio, Iowa and Illinois.

\section{Larkspur (Delphinium} a urcum, Michx.). $-\mathrm{A}$
perennial, from threefourths to one and one-half feet high with finely pubescent stem; leaves deeply five-parted, the divisions two to three-cleft, lobes narrowly linear; flowers blue, petals four, irregular, the upper pair continued backward horizontally or curved upward into long spurs, which are inclosed in the spur of the calyx, lower pair with short claws; sepals five, irregular, petal-like, the upper prolonged into a spur at the base; pods erect, many seeded. Virginia, to Georgia and west to Arkansas and Missouri, and north to Saskatchewan. In the West D. Geycri is a troublesome, poisonous plant, causing much the same trouble as that produced by $D$. tricorne in the South.

Poppy Family (Papaveraccae).-Annual or perennial herbs, with milky or colored juice; leaves alternate, stipules none; perfect, regular, or irregular flowers; sepals 
two, occasionally three, falling when the flower expands; petals four to twelve, spreading, soon falling; stamens inserted under the pistils, distinct, pistils one, many ovuled, chiefly one-celled; fruit a capsule containing numerous oily seeds. Genera 24 to 26 , species about 200. Widely distributed chiefly in the North Temperate Zone. The opium poppy (Papaver somniferum) is sometimes weedy, especially in old gardens. The smooth-pointed corn poppy of Europe (P. dubium) is found in similar places. The celandine (Chelidonium majus), with yellow flowers, a yellowish juice, is sometimes a troublesome weed.

Mustard Family (Cruciferae).Herbs or rarely woody plants with acrid, watery juice; alternate leaves without stipules; flowers in racemose or corymbose clusters, cruciform, of four deciduous sepals, and four petals, placed opposite each other in pairs, spreading and forming a cross; stamens six, two shorter, one pistil, consisting of two united carpels; fruit a pod ci:her much longer than broad (a silique) or short (silicle) or indehiscent, separating into joints; seed

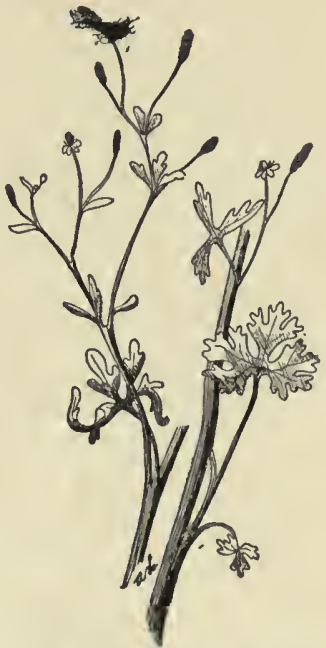

Fig. Ir3. Crowfoot (Ranunculus sceleratus). without endosperm; seed coat frequently mucilaginous; embryo large.

About I,500 species of wide distribution. The cabbage (Brassica oleracea), native of Europe, has long been cultivated.

Pennycress or French Weed (Thlaspi arvense, L.).A smooth annual, six inches to one foot high, simple or branched, root leaves petioled, stem leaves oblong or lanceolate, sparingly toothed, the upper clasping; flowers 
white in racemes, becoming elongated in fruit; pods broadly winged, notched at the apex, usually six-seeded. Waste places in wheat fields in Iowa, Minnesota, and northwest to Colorado and Utah.

Large Pepper Grass (Lepidium virginicum, L.).-An erect annual; at first stem simple, later much branched,

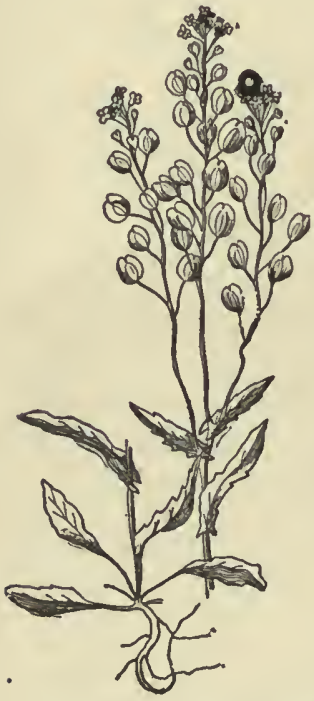

Fig. II4. Pennycress (Thlaspi arvense), a troublesome weed in grain fields. (Ada Hayden.) eight inches to two feet high; leaves divided or nearly so with the margins deeply saw-toothed, upper entire or with irregular, pointed teeth; flowers small, white; pod circular or oval with a little notch at the apex; seeds light brown, elongated, with prominent ridge on one side; on the addition of water they become mucilaginous; cotyledons accumbent. This species is a native of the Mississippi Valley, east to New England, but now occurs from Ontario, New England to Florida, west to Wisconsin, Minnesota, Nebraska, Kansas, Missouri and Texas.

Small Pepper Grass (Lepidium apetalum, Willd.).-A small pungent annual, eight inches to two feet high, its upper leaves linear and lanceolate, the lower cut and divided; flowers small, petals minute or wanting, greenish; pod roundish or flattened, notched, two seeds in each pod or one in each cell. Very common along roadsides and in timothy fields. Seeds are readily scattered by the wind and because of their mucilaginous properties, easily stick to animals or to clothing when moist. They produce some irritation because of their pungent properties and are considered as somewhat poisonous. 
Shepherd's Purse (Capsella Bursa-pastoris, (L.) Medic). - An annual or winter annual, one to one and one-half feet in height, with root leaves clustered, nearly divided or merely toothed, stem leaves sessile; flowers small, white, in fruit, spreading; pods somewhat wedge-shaped, slightly notched above, many seeded; seeds mucilaginous when moistened. It is, perhaps, the most common weed in Iowa, being found in gardens, along roadsides, in fields, and waste grounds, and in fact in every village and town in the state. Common across the continent.

False Flax (Camelina sativa, (L.) Crantz).-An erect annual, with simple or sparingly branched stem, smooth or slightly hairy; leaves erect, lanceolate or arrow-shaped, entire or nearly so; flowers small, yellow, pedicels, spreading in fruit; pod four to six inches long, smooth margined; on addition of water,

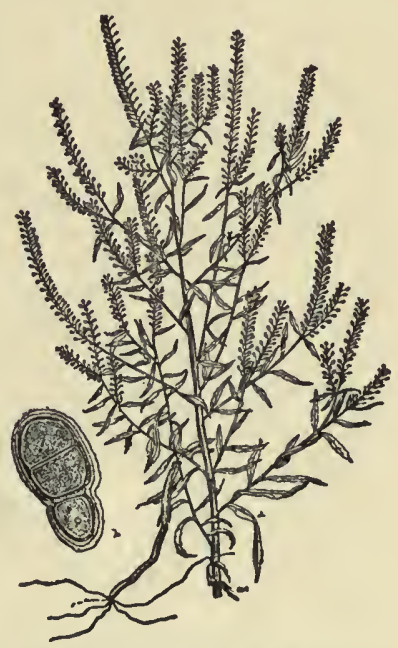

Fig. II 5. Pepper grass (Lepidium apetalum). seeds become mucilaginous.

Ball Mustard (Neslia paniculata, (L.) Desv.).-A slender, rather densely rough and hispid annual from one to three feet high; leaves lanceolate, sagittate, clasping; flowers in elongated racemes, yellow, on filiform pedicels, ascending in fruit; fruit a silicle. Common in wheat fields in the Northwest.

English Charlock (Brassica arvensis, (L.) Ktze.).-An annual or biennial, lower leaves divided nearly to the middle, the divisions being unequal, the terminal lobe longer; flowers, yellow, large and very fragrant; pod one to two 
inches long, irregular in outline, appearing somewhat knotty, three to seven-seeded or more, the upper part of the pod forming a beak; seeds round, darker than those of the black mustard and minutely pitted, mucilaginous when moistened. Very common in all parts of Iowa, and

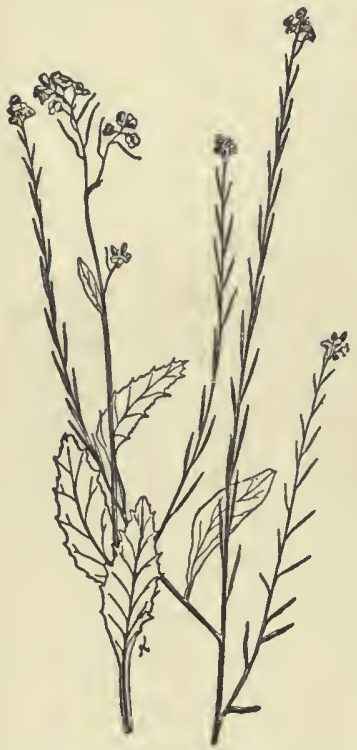

Fig. 116. Common mustard (Brassica nigra).

the Northwest and Canada. In some places, during July and August, the streets are fairly yellow with it and many fields contain a larger per cent of mustard than of grain.

Black Mustard (Brassica nigra, (L.) Koch).-Black mustard is a tall, coarse, much-branched annual, growing from two to five feet tall, with leaves variously divided or deeply cut, the terminal lobe being the largest, sharply toothed; the upper leaves small, simple, and, as a rule, linear; leaves somewhat bristly, at least on the veins; flowers yellow, smaller than those of charlock; pods smooth, about one-half inch long, four-cornered, tipped with a slender beak. This weed is very common in all parts of the North, having been reported from many different localities. It prefers rather rich soil.

Hare's Ear Mustard (Conringia orientalis, (L.) Dumort).-An erect, glabrous annual herb, with elliptical or ovate, entire, sessile, cordate leaves; flowers yellowish white in racemes, elongating in fruit; petals and sepals narrow; silique elongated, linear, four-angled. In waste places and grain fields in the Northwest, also in the East. 
Tumbling Mustard (Sisymbrium altissimum, L.).-A leafy, branched annual, growing from two to four feet tall, lower leaves runcinate, pinnatifid, irregularly toothed or wavy margined; upper leaves smaller, threadlike; flowers with four green sepals, four pale yellow petals; in older specimens only the long, slender pods show with small brownish seeds. This weed has spread with great rapidity in the United States, the first specimen having been observed on ballast ground in Philadelphia, in 1878 . It seems to have been distributed large$1 y$ by railroads and is found frequently along the right of way. It is injurious to cattle, seed containing it often causing inflammation and external irritation.

Hedge Mustard (Sisymbrium officinale, Scop.).-A coarse, unsightly annual or biennial, growing from

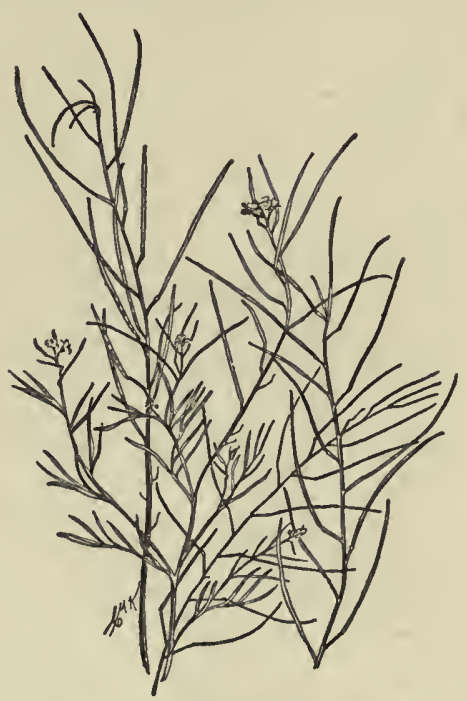

Fig. I17. Tumbling mustard (Sisymbrium altissimum.) three to six feet high with branching stem; coarsely, sawtoothed leaves, the points of the teeth turning down toward the base of the leaf; flowers small, pale yellow; calyx open; pods awl-shaped, pressed closely to the stem.

Wormseed or Treacle Mustard (Erysimum cheiranthoides, L.).-A roughish, pubescent, branching annual or biennial; leaves lanceolate, entire or slightly dentate, with a short petiole; flowers small, yellow; pods linear, fourangled, glabrous. Native to Europe, but common along streams and in moist fields in northern United States. 
The western wall flower (E. asperum) is frequently cultivated as an ornamental plant.

Horse-radish (Radicula Armoracia, (L.) Robinson).A stout perennial with long, deep roots; leaves large, oblong, crenate or pinnatifid, the latter form occurring in the spring; stem leaves lanceolate, or oblong-cordate; flowers having four green sepals and four white petals; seed seldom found in the pods, which are short and globular. A native of Europe and introduced into this country as a root furnishing a valuable condiment; but in many places it has escaped from cultivation and become a pernicious weed. When it has once become established, it is very persistent, being one of the most difficult of weeds to remove.

Winter Cress (Barbarca zulgaris, R. Br.).-A biennial, one to two feet high, stem furrowed, either simple or branched; lower leaves simple or pinnately parted, terminal lobe the largest, round or ovate; upper leaves obovate, cut, toothed or pinnatifid at the base; flowers bright yellow; pods erect or slightly spreading; cotyledons accumbent. Labrador, New England, New York, Pennsylvania, Maryland, Wisconsin, Minnesota, Iowa, Manitoba, British Columbia, mountains of Colorado, Pacific slope southward to Lower California. A native of Europe and Asia. Nearly a cosmopolitan weed, occurring also in Africa and Australia.

Caper Family (Capparidaceae).-Herbs, shrubs or, occasionally, trees; alternate leaves and cruciform flowers; sepals four to eight; petals four or none; stamens six to numerous, not tetradynamous; fruit a one-celled pod or berry with two parietal placentæ; seeds similar to those of the Cruciferæ, but with the embryo coiled.

Stinkweed or Rocky Mountain Bee Plant (Cleome serrulata, Pursh).-A glabrous annual, leaves three-foliate with bracts among the flowers, leaves and stem emit a pungent odor; flowers in racemes, rose-colored; petals entire 
with claws, stamens six; pod oblong to linear, one to two inches long, the stipe as long as the pedicel; seeds reniform, embryo coiled. From Iowa and Minnesota to the Rocky Mountains, New Mexico, Arizona, and Manitoba.

Rose Family (Rosaceae).-Herbs, shrubs or trees, leaves regular, flowers alternate or some opposite; stamens generally numerous, stipulate frequently falling soon after the leaves appear, distinct, inserted on the calyx; petals as many as the sepals or rarely wanting; pistils one to many, generally distinct, except in Pomex, where the pistil is united to the calyx; fruit various; achenes, follicles, drupes, or pomes, as in the apple; seeds one to many, without albumen; embryo straight, with large cotyledons. The order contains about go genera and $I, 500$ species of wide distribution; in temperate and tropical regions, some boreal. But few of the plants are noxious or have noxious qualities.

Common Five-finger (Poten-

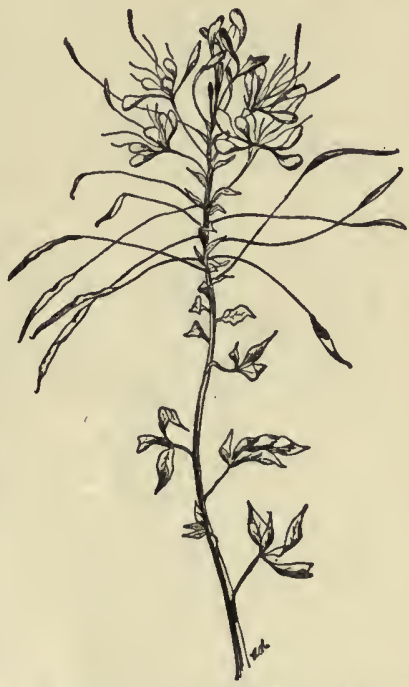

Fig. Ir8. Stinkweed(Cleome serrulata). (Ada Hayden). tilla monspcliensis, L.).-A stout, erect biennial, one-half to two feet high, with ternate leaves, obovate or oblonglanceolate leaflets; flowers yellow, in cymose clusters; calyx flat, deeply five-cleft, with as many bracts intervening; petals five, roundish; seed small, yellowish, longitudinally furrowed, sometimes reflexed. Probably introduced from Europe, though it may have been indigenous. It is now found growing in dry or wet soil from New England to the Rocky Mountains and Utah. 
Showy Cinquefoil (Potentilla fruticosa, L.).-A woody perennial with an erect, shrubby stem from one to four feet high; pinnate leaves of five to seven leaflets; yellow flowers. It is cultivated as an ornamental plant, but becomes weedy in some parts of the East, especially in Vermont, where Prof. L. R. Jones says it "is the most

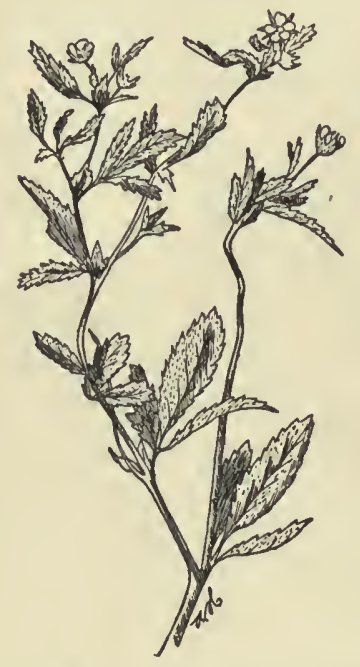

Fig. Irg. Five-finger (Potentilla monspeliensis). (Ada Hayden).

tary, yellow, petals five, calyx
five-cleft, the bractlets arranged alternately with the sepals, thus giving the appearance of a ten-cleft calyx; stamens many. This weed spreads by means of its slender, jointed runners, much in the same way that the strawberry does.

White Avens (Geum canadense, Jacq.).-A smoothish or often pubescent perennial, slender stem two feet or more high; root leaves with three to five leaflets, the terminal one broadly ovate or obovate; stem leaves threedivided or lobed, calyx bell-shaped or deeply cleft, 
stamens many, fruit densely, bristly hirsute. In shady places, especially woods, but sometimes in open fields from Nova Scotia to Georgia, west to Kansas, Missouri, Minnesota and Wisconsin, often troublesome.

Prairie Rose (Rosa arkansana, Porter).- A low shrub with prickly stem; stipules narrow, more or less glandular toothed; leaves compound; leaflets seven to eleven, broadly elliptical to oblong-lanceolate; flowers in corymbose clusters, sepals occasionally hispid. Common on the plains in Minnesota, Iowa, and westward to Colorado. Often a very troublesome weed.

Rosa Woodsii, stem with slender or recurved spines and scattered prickles or smooth; leaves with rather broad stipules, entire; fruit globose or globose-ovoid. Colorado, Utah, and the Rocky Mountain country.

The Rosa Sayii, also western, grows from one to two feet high, very prickly; stipules usually dilated, glandular and resinous; flowers usually solitary. From Minnesota to Colorado and westward.

Black Raspberry (Rubus occidentalis, L.).-This becomes a troublesome plant in northern parts of the country. The prickly stems inflict annoying scratches.

Wild Red Raspberry (Rubus idaeus, var. aculeatissimus, (C. A. Mey.) R. and T.).-This plant is often abundant in fields of the North; it may be recognized by its hairy and prickly stems. Often troublesome in the North.

Dewberry (Rubus villosus, Ait.).-This plant grows in dry, open piaces in northern and western parts of the country. Often troublesome.

Pulse Family (Leguminosae).-Herbs, shrubs; trees or vines with alternate, mostly compound, stipulate leaves, papilionaceous or sometimes regular flowers; calyx three to six or four to five-cleft; stamens ten, rarely five, and sometimes many, monadelphous, diadelphous or distinct; pistil, simple, free, becoming a legume in fruit or sometimes a loment; ovules one to many; seeds generally ex- 
albuminous, or nearly so, or, in some cases, with copious albumen. About 6,500 species of wide distribution, but most abundant in the tropics.

Partridge Pea (Cassia Chamaecrista, L.).-An annual herb with simply and abruptly pinnate leaves; spreading stems; leaflets ten to fifteen pairs, linear-oblong; flowers large, yellow, often with a purple spot at the base; anthers ten, unequal; style slender. Sandy fields, common in the Mississippi Valley and south to Texas.

C. nictitans is like the above, but smaller, the wild senna ( $C$. marilandica), grows from three to four feet high; has deciduous stipules; large leaflets; petiole with a large club-shaped gland near the base. Plant perennial. Common from southern Iowa to Illinois, southeast Nebraska and southward to Texas.

C. Tora is an annual; leaflets three, or (rarely) two pairs, obovate, obtuse, with an elongated gland; pods slender, curved. Common southward.

C. occidentalis, L. is an annual with four to six pairs of ovate-lanceolate leaflets; pods long, linear. Common southward to Texas and Arkansas.

Rattle Box (Crotalaria sagittalis, L.).-A hairy annual from three inches to one foot high, and having a small tap-root; stem villous and wing-margined; leaves, oval or oblong-lanceolate, from one-third to one-half inch wide, the edge of the leaf being hairy and entire, or somewhat wavy; stipules united and lying back on the stem, becoming inversely arrow-shaped; each peduncle produces a few yellow flowers about one-fourth inch in diameter; calyx five-cleft; standard of the corolla large and heartshaped, keel scythe shaped; stamens monadelphous, the anthers of two sizes, five being smaller than the other; the large, inflated pod bears, at first, some resemblance to the garden pea, being greenish in color, but later turns dark and varies in size from three-fourths to one inch in diameter; seeds ves small and when mature, breaking 
away from point of attachment, rattling in the pod, hence the name of the plant. Common in sandy soil, and found in large numbers on the sand bars of the Missouri River, where it may be collected by the wagon load. This plant, in Iowa, is one of the chief causes of "loco disease," and is generally regarded as poisonous.

White Sweet Clover (Melilotus alba, Desv.).-An erect annual or biennial, growing from three to four feet high; leaves compound, small white flowers, growing on rather slender flower stalks; seeds small, yellowish brown in color and with a peculiar cumarin-like odor, which also characterizes the leaves and stem. An introduced plant found throughout the northern Mississippi valley, and especially abundant along roadsides, in meadows, in fields of corn and wheat, and along the railways; spreads by means of seeds and is an annual, biennial or short-lived perennial. Sometimes used as a forage and honey plant. It has a high percentage of protein. When the plant is abundant in grain fields, flour ground from this grain has an unpleasant odor.

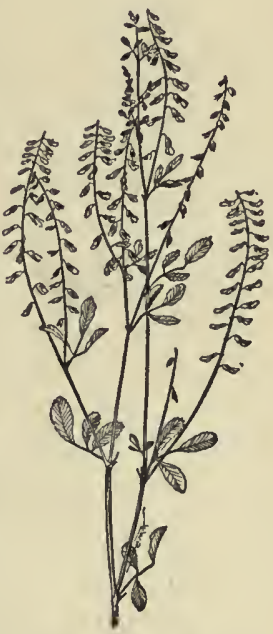

Fig. 120. Yellow sweet clover (Melilotus officinale). Hay containing it is disagreeable to stock, cattle refusing to eat it at first. There are indications also that the plant is somewhat poisonous. The yellow-flowered sweet clover ( $M$. officinalis) is troublesome and common in the West.

Low Hop-clover (Trifolium procumbens, L.).-An annual with slender and procumbent, or ascending, pubescent stems, three to six inches high; leaflets wedge-obovate, notched; stipules ovate, short; flow. ers yellow, short pedicels reflexed with age. Eastward in the eastern states, and west of the Rocky 
Mountains to the Pacific coast, largely introduced wit.. clover seed.

Yellow or Hop-clover (Trifolium agrarium, L.).-A slender, much-branched annual; procumbent or erect; six inches to one foot long; stipules broad and pointed; leaves obovate or obcordate; flowers yellow, like the pre-

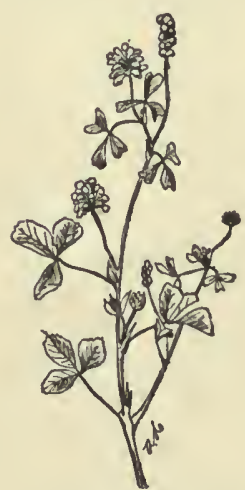

Fig. 121. Black medick (Medicago lupulina), a troublesome weed in alfalfa and clover meadows. Hayden.)

ceding; pod one-seeded.

Bur Clover or Toothed Medick (Medicago hispida, Gaertn.).-Nearly smooth annual with long, deep, wiry roots; spreading or ascending branches and few hairs; after the spring rains it produces an abundance of dense foliage; leaflets with a notch at the end, crenulate; dentate stipules; flowers small in little heads, yellow; pods in a loose spiral. Bur clover occurs occasionally in the eastern states, but is most abundant on the Pacific coast, where it was early introduced with other leguminous weedy plants.

Black Medick (Medicago lupulina, L.). -Annual with pubescent or somewhat hairy stems spreading on the ground; small leaflets, either notched at the end or pointed, with stipules, ovate or lanceolate; flowers yellow in an oblong cylindrical head; pod one-seeded, curved, not spiny, black; not infrequent in the eastern states. Common in California; considered a valuable plant.

Common Vetch (Vicia sativa, L.).-A smooth or slightly hairy annual with simple stem growing from one to two and one-half feet tall; five to seven pairs of leaflets, obovate-oblong to linear, notched at the tip, sometimes mucronate; one or two nearly sessile flowers borne in the axils of the leaves, corolla violet-purple; pod linear, several seeded; seeds black. Quite generally distributed 
throughout the wheat growing sections of the state. The seeds, like those of the corn cockle, are occasionally found in wheat screenings.

Wild Bean (Strophostyles pauciflora (Benth.) Watson). -Climbing herb; pinnately three-foliate and stipulate leaves; leaflets lanceolate or linear-oblong; flowers two to six, purplish; seeds quadrate with truncate ends; pubescent. Common in fields in southern Iowa, Missouri and southward to Texas.

$S$. helveola is also an annual with ovate leaflets having a prominent rounded lobe toward the base; terminal leaf two-lobed; flowers greenish-white or purplish. Common in sandy soil and fields from Minnesota and Wisconsin, eastward and southward.

Wood-sorrel Family (Oxalidaceae).-Stemless or leafystemmed herbs, with rootstocks or scaly bulbs, or rarely shrubs; leaves mostly palmately three-foliate, or occasionally pinnate or entire; stipules small, merely an expansion of the base of the petiole; flowers white, pink or forking cymes, or sometimes solitary; sepals five, often unequal; petals five; stamens ten to fifteen; ovary fivecelled, five-lobed; ovules two to many in each cavity; fruit generally a capsule; seed with endosperm; embryo straight. About 250 species, chiefly tropical.

Yellow Wood-sorrel (Oxalis stricta, L.).-A perennial by subterranean shoots with erect stem either glabrous or villous, without stipules; flowers yellow, sepals five, persistent, pistils five, stamens ten, pod oblong, membranaceous, five-celled; seeds two or more in each cell. Common eastward.

The $O$. corniculata, like the preceding, strigose pubescent, stipules round or truncate, pedicels longer than the leaves, two to six-flowered. A cosmopolitan weed, but much rarer than the preceding.

Geranium Family (Geraniaceae).-Herbs with alternate or opposite, simple, or palmately trifoliate leaves; fre- 
quently bulbous; flowers perfect, regular or irregular, hypogynous; stamens as many or twice as many, or more than the petals; ovary one, three or five-celled; ovules one to two to each cavity; fruit capsular.

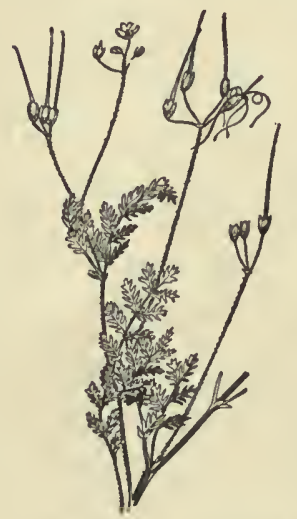

Fig. 122. Alfilaria (Erodium cicutarium).

\section{Alfilaria or Storksbill (Erodium} cicutarium, (L.) L'Her.).-A hairy, tufted annual with low-spreading stem; leaves and stem viscid or sticky, pinnate, the divisions finely divided or pinnatifid; flowers two to twelve in umbel-like clusters, purple or pink; fruit hairy and beaked, the divisions spirally coiled when ripe. Common along the Pacific coast, occurring in grain fields and waste places; also abundant in dry soils in the Salt Lake basin west of the main divide of the Rockies, in the southern Rocky Mountain region, and Texas; occasionally in the eastern states; native to the old world, but perhaps introduced into the United States for forage purposes.

Musky Alfilaria (Erodium moschatum, (L.) Willd.) Pinnate leaves; leaflets deeply and sharply serrate; prostrate stem; purple flowers; resembles the foregoing, but has a distinctly musky flavor, and pastures which are once overrun with this plant have very little value as cattle will not eat it. Native to Europe, Northern Africa and Western Asia. Common in California, but has, been reported in Massachusetts, Maine and Ontario.

Caltrop Family (Zygophyllaceae).-Herbs, shrubs or tropical trees. Leaves mostly opposite, pinnate or two to three-foliate with persistent stipules; flowers perfect, axillary. Petals same number as the sepals or none. Stamens as many as petals or more. Ovary four to 
twelve-celled. Fruit various. Troublesome weeds. Injurious in wool.

Ground Bur-nut or Caltrop (Tribulus terrestris).-Common in places along the sea coast, Nebraska and Iowa, Plant with pinnately compound leaves, small axillary yellow flowers, and burlike fruit.

Spurge Family (Euphorbiaceae).-Herbs, shrubs or trees, usually with a milky, acrid juice, opposite, alternate or verticillate leaves and monoecious or dioecious flowers, much reduced, subtended by bracts resembling a calyx or corolla; ovary usually threecelled; ovules one to two in each cell, pendulous; stigmas as many or twice as many as the cells; styles generally three; fruit a capsule, separating elastically into a twovalved capsule; fleshy or oily endosperm; seeds with flat

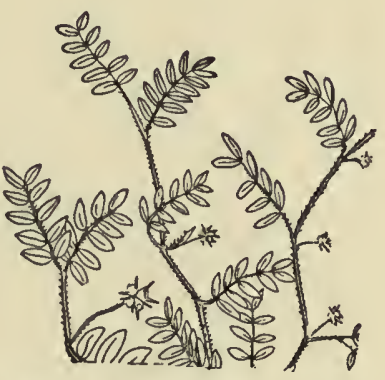

Fig. 123. Caltrop (Tribulus terrestris). cotyledons.

Bull Nettle or Tread-softly (Jatropha stimulosa, Michx.).-A stinging perennial herb, six inches to two feet high; leaves roundish, heart-shaped, three to fivelobed on long petioles, divisions entire or cut; flowers monoecious or dioecious, fragrant in a terminal, forking cyme; calyx, corolla-like, white, often salver-shaped in staminate flower, five-parted in pistillate flower; stamens monadelphous at base; capsule, a three-celled, threeseeded pod, with a caruncle. Dry soil from Virginia to Texas.

Hogwort (Croton capitatus, Michx.).-A soft, densely woolly annual, somewhat glandular, growing from one to two feet high; occasionally branched; entire, lanceolateoblong leaves with long petioles; flowers of two kinds, 
sterile and fertile, the sterile having a five-parted calyx, and five glands alternating with the obovate, lanceolate, fringed petals; fertile flowers more than one and crowded, calyx seven to twelve-parted, petals wanting; styles two or three-forked; seed smooth and gray. A common weedy plant distributed from Missouri to Texas, and from New Jersey southward to Georgia and westward to Kansas.

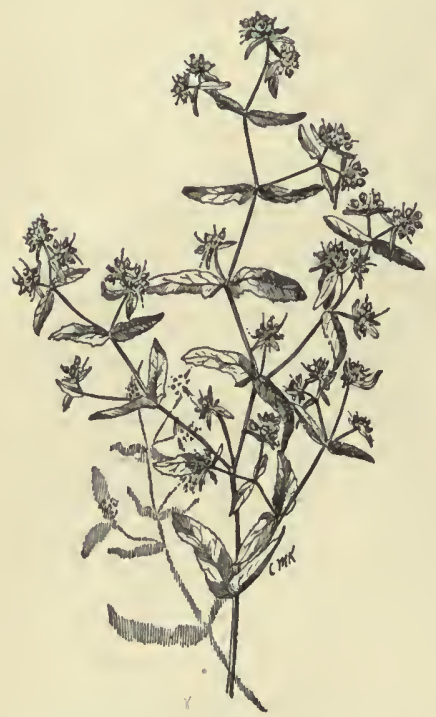

Fig. 124. Spotted spurge (Euphorbia Preslii).

The seeds are sometimes impurities in alfalfa seeds.

Three-seeded Mercury (Acalypha virginica, L.).-A rather coarse, smooth or hairy, reddish annual, often turning purple; grows one to two feet high, and has long petioled leaves, which are ovate or oblong-ovate and somewhat sparsely toothed; flowers monoecious, sterile spikes shorter than the five to nine-cleft, leaflike bracts, fertile flowers in short clusters; flowers few, one to three in each axil; seeds small, ovoid, reddish or gray and striate. They may be easily crushed between the fingers, hence the name, wax-ball, by which the plant is sometimes known. Found in New England, Ontario, and as far west as Wisconsin and Minnesota and south to the Gulf. It appears about buildings and-in waste grounds, and the seeds are frequently an impurity in clover seeds.

Spurge (Euphorbia).-The spurges are monoecious shrubs or herbs with alternate or opposite groups of lea zes arranged in whorls; flowers surrounded by a cup- 
shaped, four to five-lobed involucre, which resembles a calyx or corolla, and bears glands between the divisions; the numerous staminate flowers consist, each, of a single jointed stamen and a filament-like pedicel; the solitary pistillate flower sit. uated at the bottom of the involucre, consists of a three-lobed style and three-celled ovary, usually without a calyx; at maturity, the capsule breaks into a threelobed, one - seeded carpel; seeds variously pitted on the surface raised by numerous excrescences.

The spurges are represented $\mathrm{much}$ more numerously in the warmer regions than in the temperate zone. In the family are a few weeds, some ornamental and useful plants, and a num-

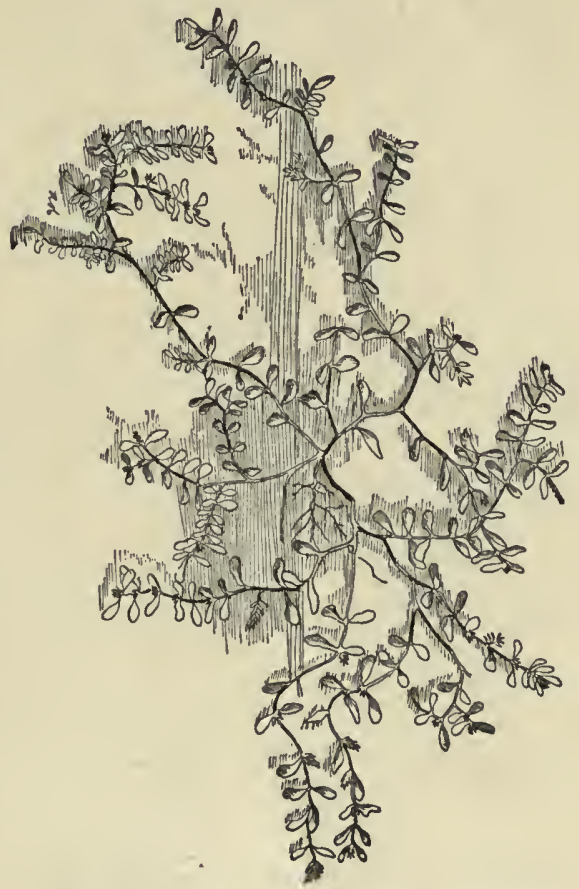

Fig. 125. Creeping spurge (Euphorbia maculata). (Ada Hayden.) ber of very poisonous species. The species that are especially interesting to residents of the Mississippi Valley are the following:

Large Spotted Spurge (E. Preslii, Guss.).-An annual, like the following, but growing erect and tall; leaves opposite and set obliquely on the stem, oblong to oblonglinear in shape, toothed and marked with a red spot or 
red margin; stipules decidedly triangular; flowers in loose terminal cymes with entire, white or red appendages; pod smooth and angled; seeds small, nearly black, wrinkled and tubercled. Quite generally distributed throughout the region east of the Rocky Mountains.

Spotted Spurge (E. maculata, L.).-A prostrate, spread-

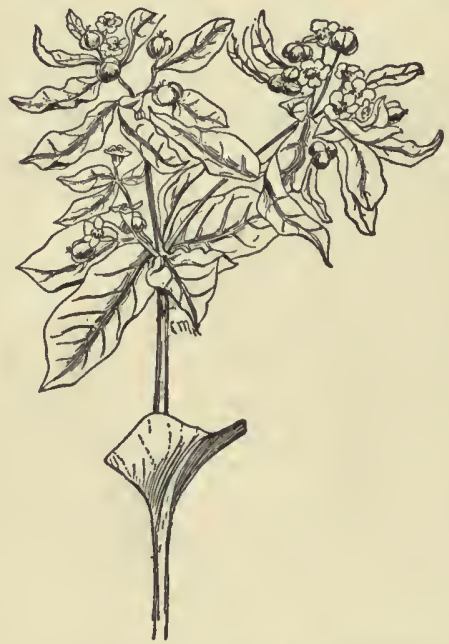
ing, hairy annual with oblong linear leaves, which may be either hairy or smooth, rather oblique at base and toothed above, and marked with small brownish spots; stipules lanceolate and threadlike; flowers included in a four to five-lobed involucre which has minute glands; peduncles as long as the petioles, and in dense clusters; pods minutely hairy; whitish seeds sharply fourangled and indented with four shallow grooves. One

rig. 126. Spurge (Euphorbia marginata), common in the West.

of the most common kinds of spurge found east of the Rocky Mountains; seen along roadsides, walks, and in waste places.

Snow-on-the-Mountain (E. marginata, Pursh).-An erect annual introduced as an ornamental plant, and escaped from old gardens; grows two to three feet tall, and has a smooth or somewhat hairy, stout stem with sessile, scattered leaves that are entire, ovate or oblong and-have deciduous stipules; uppermost leaves opposite or whorled with conspicupous white borders; flowers borne in umbels surrounded with bell-shaped, five-lobed involucres, the glands of which are furnished with broad, white append- 
ages; seeds ovoid, and dark colored. Native in regions extending from western Minnesota to Colorado. The milky juice exuding from the broken stems causes an itching sensation wherever it touches the flesh, the general effect being similar to that produced by poison ivy. The honey obtained by bees from this plant is poisonous, and thus entirely unfit for use.

Toothed Spurge (E. dentata, Michx.).-A dull green, hairy annual, with an erect ascending stem eight to fifteen inches high; lower leaves alternate, upper whorled and opposite, varying in shape from ovate to linear, three and one-half to five inches long and coarsely toothed, pale at the base and narrowed into slender petioles, nerves very prominent beneath; involucres in terminal clusters, bearing one to four yellowish, short-stalked glands; seeds ash-colored, slightly four-angled. Distributed from Pennsylvania westward to South Dakota and southward to Louisiana and Mexico.

Cruel Plant (E. heterophylla, L.).-An erect, smooth annual, growing from one to three feet high, with alternate, petioled leaves which vary in shape from linearlanceolate to orbicular and with margins that may be entire, wavy, or toothed; upper leaves usually fiddleshaped, each with a red spot at the base; involucre in terminal clusters, five-lobed, with a single gland or a few that a re almost sessile ; seeds roundish, wrinkled transversely and tubercled. Rather sparingly distributed through Illinois, westward to Nebraska, and southward into Missouri.

Cypress Spurge (Euphorbia Cyparissias, L.).-A bright green perennial growing six to twelve inches tall, and occurring in patches; it has creeping rootstocks; clustered stems; entire leaves, those of the stem linear and densely crowded, those of the flower heart-shaped; flowers in umbellate clusters, the umbel being many-rayed, with crescent-shaped glands; pods granular; seeds oblong and smooth. Originally introduced from Europe as an 
ornamental plant and frequently found in old cemeteries. It has become quite widely scattered so as to be regarded in many places as a weed.

Cashew Family (Anacardiaceae).-Trees or shrubs characterized by acrid properties, milky or resinous juice, alternate or opposite leaves and small regular flowers which are frequently polygamous; calyx three to sevencleft; petals as many as the divisions of the calyx; stamens as many or twice as many as the petals and inserted at the base of the disk; ovary one, sometimes four or five-celled, with one ovule in each cell; styles one to three, fruit generally a small drupe.

Poison Ivy (Rhus Toxicodendron, L.).-A twining or trailing shrub of rather attractive appearance, but distinguished from other vines which resemble it somewhat by its compound leaf of three leaflets; by means of aerial rootlets it is enabled to cling to trees or other objects for support; flowers small and inconspicuous; fruit waxy, frequently remaining on the plant until late winter or early spring; leaves somewhat resemble the box-elder and Virginia creeper, both of which, however, have five leaflets; every part of the plant possesses irritating properties to which some people are very sensitive; others seem to be immune. However, this is known as one of our most poisonous plants, death sometimes resulting from contact with it. Sugar of lead in solution applied to the affected parts is the usual antidote for ivy poisoning. Common everywhere in the state.

Soapberry Family (Sapindaceae).-Trees or shrubs with simple or compound leaves; flowers perfect, polygamous, regular or irregular; calyx of four or five sepals; petals of the same number or none; stamens inserted on a fleshy disk, hypogynous or perigynous, five to ten; ovary two to three-celled and lobed, exalbuminous or albuminous; cotyledons folded, convolute or straight. About r,roo species, widely distributed in temperate 
regions. The sub-order, Sapindaceæ, is largely tropical. The maple (Acer) is commonly used for the manufacture of furniture and for interior finishings, floorings, etc. The most highly prized are the hard maples (Acer nigrum and A. saccharum). Sugar maple is also derived from these species. Curly maple is only a form of wood of these and the A. macrophyllum of the Pacific coast is also much prized for cabinet work, especially when the curly maple wood is used.

Balloon Vine (Cardiospermum Halicacabum, L.).-A delicate, smooth or slightly hairy, climbing or spreading herb with alternate, petioled leaves which have shortstalked segments, ovate or oblong, acute or acuminate and sharply toothed; flowers white and somewhat irregular, sepals four, having two longer than the others, and two upper petals larger than two lower;

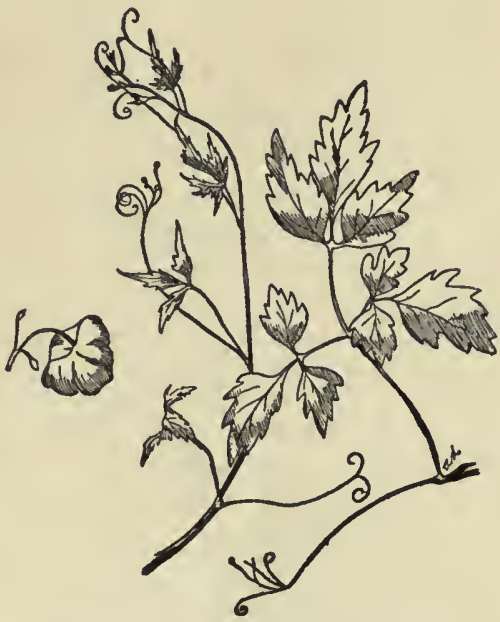

Fig. x27. Balloon vine (Cardiospermum Halicacabum). (Ada Hayden.) disk one-sided; stamens eight, filaments unequal; style three-cleft, ovary three-celled; capsule inflated, threelobed; seeds nearly black, with aril or wing at the base. The plant climbs by means of hooklike tendrils which spring out from the flower clusters. Native in the southwestern states and frequently cultivated for its inflated pods; found in waste places and occasionally seen in ballast about seaports.

Mallow Family (Malvaceae).-Herbs, shrubs, or, in tropical countries, trees with mucilaginous properties, 
tough fibrous bark and stems; leaves alternate with small stipules; flowers regular and generally perfect ; sepals five, usually more or less united; petals five, hypogynous; stamens numerous, monadelphous, several-celled; pistils several; styles united, projecting beyond the stamens above; ovary several-celled; seeds nearly exalbuminous;

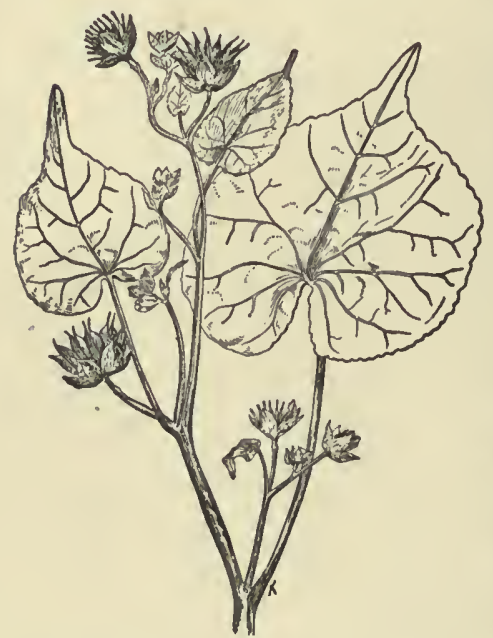

Fig. 128. Butter print (Abutilon Theophrasti). pointed, velvety; toothed or nearly entire flowers, small, yellow; fruit in the shape of an old-fashioned butter print with twelve to fifteen seeds, opening at the apex, each carpel beaked by a slender awn; stem tough, fibrous. Common in the middle and eastern states, but less frequent in the North. Native to Asia.

False Mallow (Malvastrum coccineum, (Pursh) Gray) -A low, hairy perennial herb, with dense, silvery, stellate pubescence; lower leaves pedately three to five-parted; flowers small, red, in dense short racemes, usually with- 
out bractlets. Calyx lobes shorter than the petals; carpels ten or more, indehiscent, rugose and usually oneseeded. From South Dakota to Texas and New Mexico and west to British Columbia.

Prickly Sida (Sida spinosa, L.).-A finely pubescent annual, growing ten to twenty inches high; ovate-lanceolate leaves, sometimes oblong, sharply toothed and borne on long petioles; flowers yellow, axillary and solitary, the calyx being five-cleft, and the petals five; carpels five, united into one fruit, splitting at the top into two beaks; seeds dark brown, rather crescent shaped, smooth and only one inch long. Found on dry ground or waste places from Maine westward as far as Iowa and southward to Florida and Texas.

Paroquet Bur (Sida stipulata, Cav.).-A nearly smooth herb with erect or curving stem; leaves lanceolate or oblong; stipules linear-subulate, longer than the petioles, flowers single or clustered, reddish or yellowish; carpels reticulated and two incurved spines. A troublesome weed, common in the southern states from Florida westward.

Mallow, Cheeses (Malva rotundifolia, L.).-A creeping procumbent, coming from a deep biennial or annual root; stems from one to two feet long; leaves round, heartshaped on long petioles; flowers clustered in the axils, whitish; calyx with a three-leaved involucel at the base; five sepals united at the base and persistent; corolla five petals; stamens monadelphous, anthers opening along the top; pistils, several, united into a ring forming a severalseeded pod, seeds triangular kidney-shaped. This weed is widely distributed throughout eastern North America.

Okra or Gumbo (Hibiscus esculentus, L.).-An annual from two to four feet high; leaves cordate, five-lobed, obtuse, toothed, petioles longer than flowers; involucre about five-leaved, dropping after flowering; calyx cleft; stamens monadelphous, fruit elongated, five-celled; pod 
mucilaginous. Extensively cultivated in the South and frequently persistent as a bad weed.

The Shoo-fly or Bladder Ketmia (H. Trionum, L.).Is a low, rather hairy annual, upper leaves three-parted; fruiting calyx inflated; membranaceous, five-winged; corolla sulphur yellow with a blackish eye; flower lasts a short time only. Native to Europe, but has become

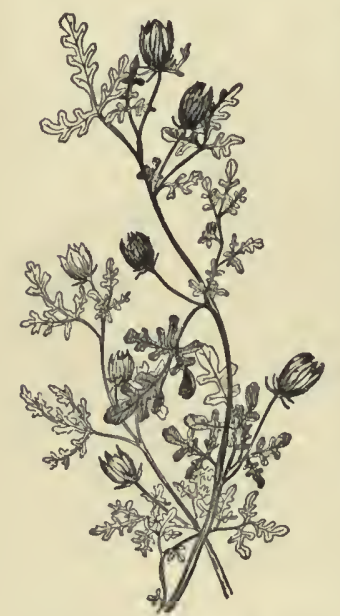

Fig. 129. Shoofly (Hibiscus Trionum). very common in Texas and other southern states as well as in the North.

Spanish Bur (Urena lobata, L.).A shrubby, tomentose herb with rigid branches and pubescent foliage; leaves alternate, blades angled or lobed, orbicular-reniform or oval on upper part of stem, shallowly three to five-lobed, serrulate, cordate or rounded at the base, whitish and prominently nerved beneath; petioles shorter than the blades; flowers in racemes, perfect, often inconspicuous, sessile or short peduncled in the axils of the leaves; bractlets of involucel five to seven, linear-lanceolate; petals five, pink or rose-colored, very delicate; sepals five, united below, often adnate to the involucel, about as long as the bractlets, often ovate, acute; carpels bristly, subglobose. In waste places in Florida and as far west as Alabama. Naturalized from Europe.

St. John's-wort Family (Hypericaceae).-Shrubs or herbs with opposite, entire, chiefly sessile leaves, punctate with translucent and occasionally blackish dots; perfect flowers; few to many stamens arranged in clusters, usually three to five; pod one to seven-celled, filled with numerous small seeds; juice both acrid and resinous. 
Common St. John's-wort (Hypericum perforatum, L.). -A much-branched perennial with numerous sterile shoots at the base; leaves sessile, oblong or linear, punctate with black dots; flowers borne in cymose clusters, and have five green sepals shorter than the five yellow and black dotted petals; stamens many, in several clusters. Common in the eastern states, but rarely found west of the Mississippi or in the southern states. It is believed in some localities to be poisonous.

Violet Family (Violaceae). -Usually herbs or rarely shrubs or trees, caulescent or acaulescent; with alternate, simple, entire, or lobed leaves with stipules; flowers mostly irregular; sepals five, corolla of five petals, one of which is spurred, hypogynous; stamens five, short; filaments broad and flat, often cohering with each other around the pistil ; ovary simple, one-celled, with two parietal placentæ; fruit a capsule; seeds anatropous. About 300 species of wide distribution.

Heart's-ease, or Pansy

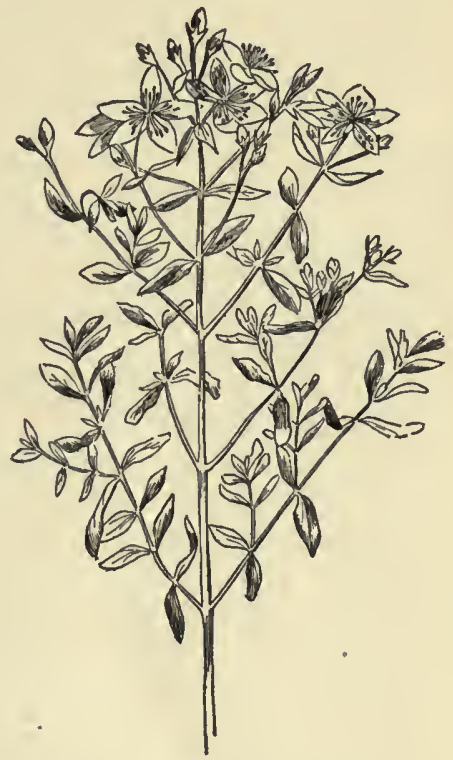

Fig. 130 . St. John's-wort ( $H y$ fericum perforatum), common in fields of the North. (Ada Hayden.) (Viola tricolor, L.).-A leafy-stemmed, smooth annual, branched and ascending; upper leaves oval-lanceolate and crenately toothed, lower broader and often heartshaped, with large leaflike stipules; flowers solitary with five spreading petals, variously marked with yellow, purple and white, the lower petal being the largest; 
sepals five and spurred, becoming less distinct with cultivation. Sometimes found in waste places, having escaped from old gardens.

Primrose Family (Onagraceae).-Herbs or rarely shrubs, with alternate or opposite leaves, generally without stipules, or stipules glandular; calyx adnate to the two to four-celled ovary, petals two to nine; stamens as many as the petals or twice as many; ovtules numerous. About 300 species. A few of the plants are medicinal. The great willow herb (Epilobium angustifolium) is occasionally used in medicine. Many species are used for ornamental purposes, especially some of the western species of the genus, such as Oenothera, the Clarkia elegans of the gardens, and greenhouse Fuchsia.

Fireweed (Epilobium angustifolium, L.).-A simple stemmed perennial growing from four to seven feet tall; nearly entire, lanceolate leaves pale beneath and green above; rather showy flowers in long racemes, the calyx limb being deeply parted; petals purple or pale and four in number; seed has a long soft coma at one end. This fireweed is very abundant in burned-over districts of Oregon and Washington; also found very frequently in northern and central Minnesota and Wisconsin, but rarely seen growing in Iowa; considered an excellent honey plant.

Gaura (Gaura biennis, L.).-A soft, hairy biennial from three to eight feet high; leaves alternate sessile, oblong lanceolate denticulate; flowers in wandlike spikes; calyx tube prolonged beyond the ovary; lobes four, reflexed; petals clawed, unequal, rose-colored; stamens eight ; stigmas four-lobed; fruit oval or oblong, ribbed and downy. Common from New England to Minnesota and Nebraska. The hairy gaura ( $G$. parviflora) is a softly villous herb two to five feet high with ovate-lanceolate, softly pubescent leaves; fruit oblong, four-nerved, small. From Iowa to Utah. The purple gaura $(G$. coccinea) is a low 
anescent or smooth leafy perennial with linear or linearoblong leaves, entire or denticulate; flowers in loose spikes, rose-colored; fruit roundish or four-sided below. Common in western Minnesota, Iowa and westward.

Evening Primrose (Oenothera biennis, L.).-A stout, erect annual or biennial, more or less pubescent and hairy; leaves lanceolate to oblong, acute or acuminate, denticulate, the upper sessile, the lower petioled; calyx tube prolonged beyond the ovary; the lobes reflexed; petals four, yellow, valves containing many small seeds. An immensely variable species. From the Atlantic to the Great Basin of Utah. Often a very troublesome weed.

Carrot Family (Umbelliferae).-Herbs with compound or sometimes simple leaves; petioles often dilated at the base, rarely with stipules; flowers numerous, small in compound or simple umbels or heads, frequently polygamous; calyx tube adnate to the ovary, limb obsolete or five-toothed; petals five, inserted on the margin of the calyx; stamens five, inserted on the disk; pistils with two styles; fruit dry, composed of two carpels, generally spreading from each other at maturity.

Poison Hemlock (Conium maculatum, Evening primL.).-An erect, branching, smooth herb, rose (Oenothera with spotted stem and pinnately decom-

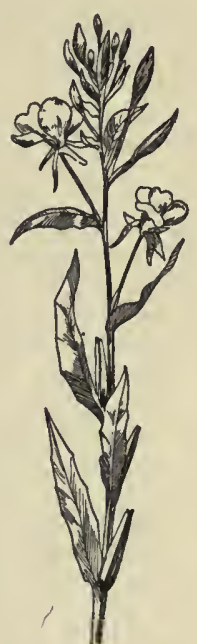
biennis). pound leaves; flowers small, white, in compound umbels; calyx teeth obsolete, petals white; fruit smooth, ovate, flattened, with prominent, wavy ribs; oil tubes absent. In waste places, Canada to Indiana, California and Mexico; native to Europe. Poisonous.

Cowbane (Cicuta maculata, L.).-A smooth marsh perennial, two to five feet tall, with pinnately compound 
leaves, two to five times pinnate, and with long petioles; leaflets coarsely serrate, lance-shaped to oblong-lanceolate; flowers white; fruit broadly ovate to oval, small, one and one-half inches long; roots three to five, clustered and occasionally single, emitting a strong odor which is intensified in boiling. Grows in marshes and

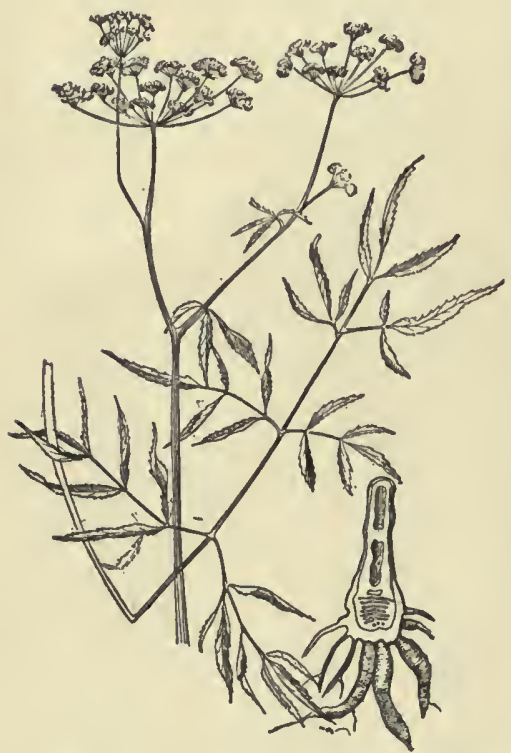

Fig. 132. Cowbane (Cicuta maculata). A dangerous poisonous weed of the North. (Ada Hayden.) low grounds, the stem. springing up from thick, fleshy roots that taper at the lower end; intensely poisonous, the poisonous properties residing in the root and stem, but more particularly in the root, seeming to occur in an oily, aromatic fluid. Widely distributed in northern states and in the Rocky Mountains. Poisonous.

Water Hemlock ( $\mathrm{C} i$ cuta bulbifera, L.).This is found in marshes in the northern part of the country. It has small white flowers in the axils of the leaves. Poisonous.

Caraway (Carum Carui, L.).-A smooth, erect herb; leaves pinnately compound with small divisions; flowers small, white in $t 1 \mathrm{~m}-$ bels; calyx teeth small; fruit ovate or oblong, smooth, with inconspicuous ribs; face of seed plane. Commonly naturalized eastward and abunclant westward, especially in Utah.

Wild Parsnip (Pastinaca sativa, L.).-Tall, branched biennial or annual herb with thick conical roots, pin- 
nately compound leaves, smooth or somewhat pubescent, calyx teeth obsolete; petals yellow, fruit oval, glabrous, flattened dorsally; seeds flat. Common in the northern states and on the Pacific coast, where it has escaped from cultivation.

Wild Carrot (Daucus Carota, L.).-An erect biennial, sonetimes. annual, growing from one to three feet tall; with deep, conical, fleshy root; lower and basal leaves two to three pinnate, segments being linear or lanceolate in shape, toothed and lobed, upper leaves smaller and less divided than the lower; bracts of involucre parted into threadlike divisions which close more or less closely around the bud, giving it the delicate lacy appearance which has caused the plant to be called Queen Anne's lace; flowers in umbels, two to four inches broad, with numerous, crowded rays, the inner shorter than the outer, making upper surface of blooming umbel concave; pedicels very slender, one-half to two inches

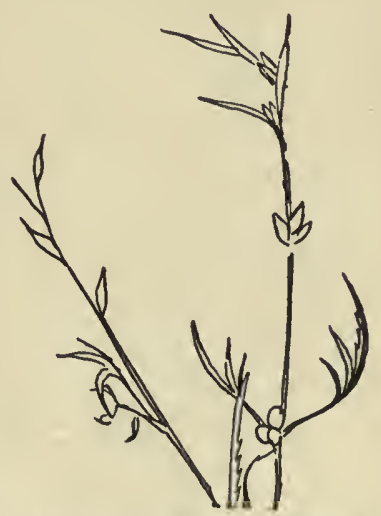

Fig. 133. Water hemlock (Cicuta bulbifera). (C. M. King.) long in fruit; flowers white, the central one of each umbel as well as the central flower of each umbellet being sometimes purple; occasionally entire cluster is pinkish; fruit one and one-half to two inches long, bristly with winged ribs. Found in waste fields and rapidly becoming a troublesome weed in Iowa. It is the original plant from which the cultivated carrot has been developed.

The small carrot ( $D$. pusillus) is a biennial with finely dissected leaves, leaf segments linear, smaller than the wild carrot; stem retrorsely hispid. 
Dogbane Family (Apocynaceae).-Perennial herbs, shrubs or vines, with milky or acrid juice and entire, mainly opposite leaves, without stipules; perfect, regular, five-parted flowers; five-lobes of the gamopetalous flowers convolute and twisted in the bud; calyx persistent, lobes

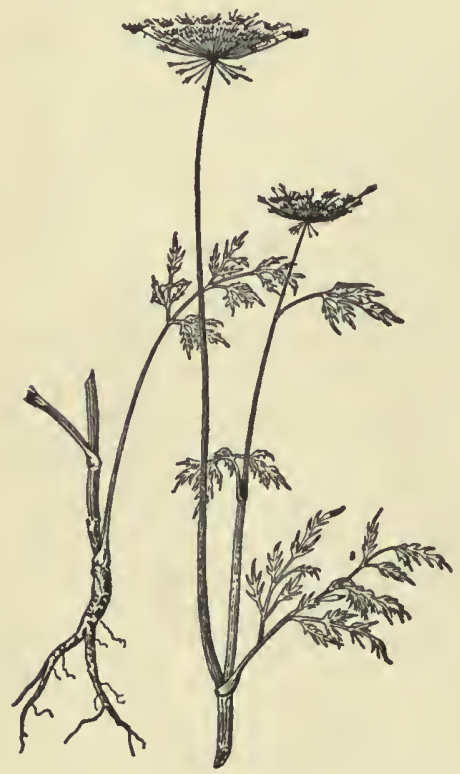

Fig. 134. Wild carrot (Daucus Carota). A troublesome weed of the East. (After Harrison and Lockhead.) imbricated in the bud; stamens as many as the lobes of the corolla, alternate with them and inserted on the tube or throat; pollen granular; ovary superior with two distinct ovules; fruit in our genera follicles; seeds with a large straight embryo, often bearing a tuft of hair. One hundred and twenty-five genera and I,000 species, which are very widely distributed, especially in the tropics.

Spreading Dog b a n e (Apocynum androsaemifoli$u m$, L.).-Rootstocks horizontal, smooth, or rarely soft-tomentose; branched above, spreading; leaves ovate, petioled; cymes loose, spreading, both terminal and axillary; calyx segments shorter than the tubes of the corolla, the latter pale rose color, open, bellshaped. Common borders of thickets from Canada to British Columbia, Arizona and Georgia.

Indian Hemp (Apocynum cannabinum, L.).-Glabrous or more or less soft-pubescent, two to three feet high, smooth, terminated by an erect, close, many-flowered 
cyme; corolla lobes nearly erect, tube not longer than the lanceolate segments of the calyx, greenish white; appears iil July and August. Common species eastward and troublesome as a weed in northern Mississippi Valley.

Milkweed Family (Asclepiadaceae.)-Perennial herbs, vines, or shrubs, with milky juice and entire, opposite, or whorled leaves; flowers in umbels, regular; calyx inferior, corolla bell or urn shaped, rotate or funnel form, five-lobed or five-cleft, segments generally reflexed; crown between the corolla and stamens; stamens five, inserted on the corolla, generally monadelphous, anthers connivent around the stigma, or more or less united with each other, commonly bearing an erect or inflexed membrane; pollen collected in masses, generally ten, known as pollinia; ovary of two carpels, in fruit of two follicles, seeds flattened, usually appendaged by a long tuft of hairs called a coma. About 200 genera containing 1,800 species widely distributed, many members of the order being weedy, some medicinal and a few economic.

Showy Milkweed (A. speciosa, Torr.).-A perennial from one to four feet high, white tomentose or canescent; leaves thick, broadly ovate or oval, petioled; pedicel glabrate above, flowers borne in dense umbels or merely solitary, the pedicels stout; corolla purplish green, large; follicle erect or spreading on the recurved pedicels. In Iowa, Minnesota, Nebraska, Kansas, Utah, California and British Columbia. Very common at times in grain fields and meadows. The swamp milkweed (A. incarnata) has acuminate leaves; flowers in umbels, which are numerous and many-flowered; corolla red or rose-purple or rarely white, the incurved horns longer than the hood, follicles. erect. Common in swamps in the North. The butterfly weed (A. tuberosa) has alternate, ligulate or oblong sessile leaves; flowers in cymose umbels, bright orange or yellow. Common on prairies, sandy fields and openings. The white milkweed (A. verticillata) has fascicled roots, 
slender stem, numerous leaves, which are narrowly linear, sessile and mostly whorled; flowers in umbels, greenish white.

Milkweed (Asclepias syriaca, L.).-A perennial herb with a stout stalk, growing from two to five feet high, armed with fine, soft hairs; leaves oblong, oval or ovate,

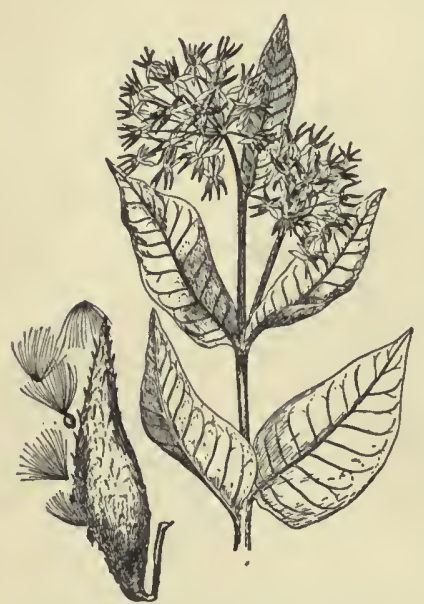

Fig. 135. Milkweed (Asclepias syriaca). (C. M. King.) obtuse or roundish at the base, the young leaf somewhat pubescent above, finally becoming smooth, petioles stout; flowers borne in umbels, few to many, peduncles hairy or tomentose; corolla a dull or greenish purple, occasionally pale in color; fruit a pod containing a large number of flattened seeds with downy appendages which aid in distributing the seed; propagated both by seeds and "underground roots," and said to be poisonous to stock.

Convolvulus Family (Convolvulaceae.)-Contains twining or trailing herbs with a few shrubs or trees, some having milky juice; leaves alternate without stipules; flowers regular and perfect, calyx inferior, five-parted or five-divided; corolla five-lobed, plaited, convolute or twisted in the bud; stamens five, inserted on the tube of the corolla and alternate with its lobes; ovary two to three-celled, with a pair of erect ovules in each cell. The I,900 species of this family are widely distributed, but are found chiefly in warm regions. Among them are several economic plants, such as the sweet potato (Ipomoea Batatas), which has been widely cultivated in all tropical and sub-tropical countries. 
Ivy Leaved Morning Glory (Ipomoca hederacea, Jacq.). -A twining or trailing shrub, the stems having retrorse hairs; leaves ovate-orbicular, three-lobed, the lobes acute or acuminate; flowers in one to three-peduncled clusters, with peduncles shorter than the petioles, opening in early morning, white, purple, or pale blue; sepals lanceolate, pointed, hairy below; corolla funnel-form, the tube nearly white, light blue or purple; capsule depressed, three-valved. Found in waste places and fields from New York southward and west to Missouri and Nebraska.

The Common Morning Glory (I. purpurea) is an annual with retrorsely hispid hairs on stem, leaves heart-shaped, acuminate, entire; peduncles three to five-flowered, funnel-form; corolla purple, pink, or white; capsule depressed, globose. Commonly cultivated, becoming an escape from cultivation, especially southward. The man of the earth, or wild potato vine ( $I$. pandurata) is a smooth, trailing or twining perennial, with large roots; slender petioled leaves which are cordate, acuminate or occasionally fiddle-shaped; peduncles larger than the petioles; one to five-flowered; corolla white with purple on the inside, funnel form. Occurs from New England to Missouri and Texas. The bush morning glory (I. leptophylla), with a large root, erect stem, linear leaves, one to two-flowered peduncles, and large flowers, occurs from Nebraska to Texas.

Hedge Bindweed or Wild Morning Glory (Convolvulus sepium, L.).-A smooth, occasionally pubescent perennial vine, twining around supports or trailing on the ground; leaves triangular, halberd or arrow-shaped, with pointed tips, the basal lobes obliquely or truncately lobed; flowering peduncles four-angled, with two leaflike bracts which are commonly acute; flowers large; corolla white or tinged with purple; seeds rather large and black. Very generally distributed throughout United States and common in corn fields, meadows, grain crops and along 
the roadsides; scattered largely through commercial grain seeds, morning glory seeds appearing as impurities. It is also easily propagated by roots and again by the seeds being scattered as the pods are blown over the snow; it chokes out vegetation, preventing growth of grain, and frequently hinders the corn from maturing; where com-

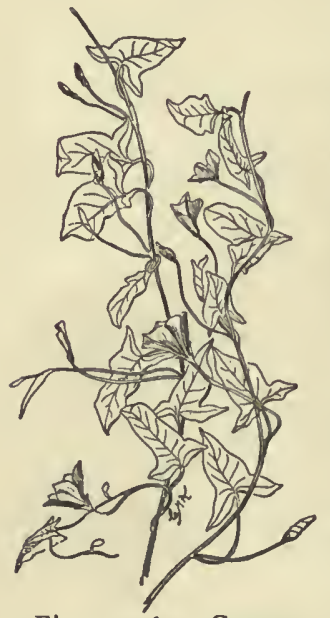

Fig. 136. Common hedge bindweed (Convolvulus sepium). mon, may reduce the corn crop onehalf. It has even been suspected of being poisonous.

European Bindweed or Morning Glory (Convolvulus arvensis, L.).-A deep-rooting perennial with a twining or creeping stem, except where there is no support, in which case it trails on the ground; leaves from one to two inches long, ovate, oblong, and arrow-shaped, the lobes at the base running to a point; flowers borne in one-flowered peduncles with very small bracts at some distance below the flower; flowers one inch or less long, broadly funnelshaped, white or frequently rose tinged; the plant propagates freely by underground rootstocks. It was introduced originally as a garden plant, but has become quite troublesome, the seeds having been widely distributed as impurities in commercial garden or clover seeds. In corn fields it is especially annoying, because its twining habits enable it to choke out other crops.

Dodder (Cuscuta.) - Herbs of reddish color, probably perennial, leafless except for the small scales on the threadlike stems which twine around the plants on which they live. Dodders pierce these plants or hosts by means of small, short rootlets which are called suckers or haustoria; seeds very small, but contain enough nourishment 
to provide for germination and for sufficient growth of stem to enable the plant to reach some other plant into which it immediately sends its suckers and thus becomes established upon its host from which it afterwards obtains its nourishment. Dodders contain no green coloring matter, or chlorophyll as it is called, so are unable to assimilate raw material and make starch of it as greenleaved plants do, hence are dependent upon other plants for nourishment that has already been converted. Such plants are called parasites. Dodder seeds retain their vitality five years or more, hence must be considered as especially pernicious when present in commercial seeds.

Clover Dodder (Cuscuta Epithymum, Murr.).-Slender, reddish stems; capitate flowers with pink calyx, corolla with four to five erect lobes; scales large, incurved; stemless, exserted, filiform stamens; capsule circumsessile with withering corolla. Found in both clover and alfalfa; native to Europe, but now found in the United States from New England to Iowa and South Dakota, the Rocky Mountains and the Pacific coast. The large seeded Chilean dodder (C. racemosa, var. chiliana) is found in clover seed sent from Chili.

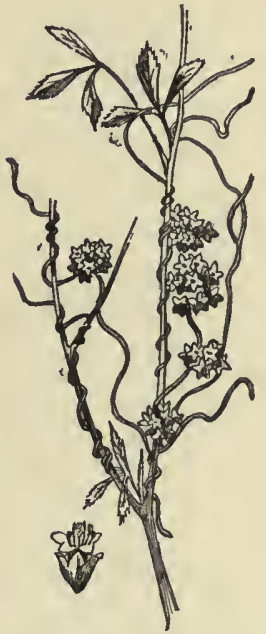

Fig. 136a. Clover dodder on alfalfa. (Dewey.)

Field Dodder (Cuscuta arvensis, Beyriçh).-Pale yellow, filiform stems; flowers in small, nearly sessile clus. ters; calyx of five obtuse lobes ; corolla nearly campanulate, five-lobed, longer than the tube, tips reflexed; scales large, ovate; stamens not exserted; style shorter than the ovary; stigmas capitate; capsule globose, indehiscent. A parasite on shrubs and various herbs as well as on clover and alfalfa from New England to Florida, Canada to the 
Rocky Mountains, California and Mexico. C. decora, found in the southern states, has coarse stems, panicled, papillose flowers, triangular calyx lobes, pointed capsule and is seen on alfalfa. Flax dodder (C. epilinum) has slender, reddish stems, flowers in loose clusters, linear filiform stigmas and occurs rather sparingly on flax in the northern states.

Phlox Family (Polemoniaceae.)-Herbs

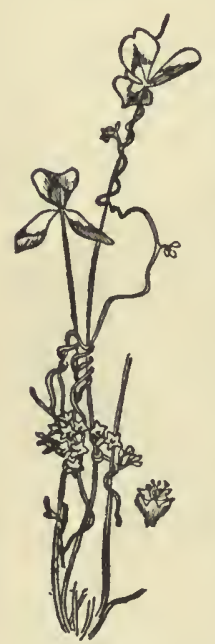

Fig. ${ }_{3} 6 \mathrm{~b}$. Field dodder (Cuscuta arvensis) on red clover. (DeweyHayden.) with alternate, opposite leaves; flowers perfect, regular, clustered; calyx bellshaped, five-cleft; corolla gamopetalous, the limb five-parted; stamens five, inserted on the tube of the corolla and alternate with the lobes; pistil with a three-celled ovary and a three-lobed style; ovules two to many; fruit a capsule, three-celled, three-valved; seed-coat sometimes mucilaginous, producing spiricles; embryo straight; cotyledons flat. About 200 species of wide distribution.

Skunkweed, Pepperweed (Navarretia squarrosa, H. and A.).-A rigid, rather stout annual, becoming much branched; very glandular, viscid, fetid; leaves twice pinnatifid or pinnately parted and the divisions either parted or incised, upper leaves and bracts spinescent; flowers densely clustered; corolla blue, rarely whitish, funnel form or almost salver form, rather shorter than the usually entire calyx lobes; calyx lobe often laciniate or spinulose-tipped; stamens unequal in length, slender, tubular. Open ground, common hroughout western California and in the foothills extending into Oregon.

Waterleaf Family (Hydrophyllaceae.)-Mostly hirsute herbs with alternate or rarely opposite leaves; flowers 
perfect, regular, five-parted in spikes, racemes, cymes or solitary; stamens five, inserted on the corolla; style twocleft or two separate styles; ovary one to two-celled, when one-celled with two parietal placentæ; fruit a twocelled capsule; seeds mostly reticulated. A small order of about 160 species.

Waterleaf (Ellisia nyctelia, L.).-A minutely or sparingly roughish, pubescent, branched annual from six to fourteen inches high; leaves pinnately parted into seven to twelve lanceolate, or linear-oblong, cut-toothed divisions; peduncles one-flowered, calyx lobes lanceolate, pointed; corolla whitish; stamens included; capsule globose. In grain fields and moist places from the Central States to Dakota and Northwest Territory to Kansas.

Borage Family (Boraginaceae.)-Herbs, shrubs or trees, with alternate, entire, rough, or frequently scabrous or setose leaves; flowers perfect, usually regular, generally blue, borne in one-sided spikes, racemes, cymes or scattered; calyx inferior, mostly five-lobed or five-cleft; corolla short, bell or wheel-shaped, five-cleft or fiveparted; stamens as many as the lobes of the corolla and alternate with them; ovary superior, deeply two-lobed, style entire; capsule globular; fruit usually forming four seedlike, one-seeded nutlets, but sometimes separating into two, two-seeded nutlets.

European Heliotrope (Heliotropium europaeum, L.).An erect annual, branched, roughish, pubescent; leaves oval; petiole long, narrow at the base; flowers borne in one-sided bractless spikes, the terminal spikes in pairs; calyx spreading, the segments shorter than the corolla tube; anthers, distinct, obtuse. Common in waste places, southward, and from New Ycrk to Pennsylvania and Florida.

Stickseed (Lappula echinata, Gilbert).-An erect annual from one to two feet high; pale, leafy, hispid with erect branches; leaves linear or linear-oblong; racemes 
one-sided, bracteolate; calyx segments lanceolate; corolla blue; nutlets rough granulate or tuberculate on the back, the margins with a double row of slender prickles. Abundant in waste places along roadsides from eastern Canada and New England to Minnesota, Kansas and British Columbia. Weedy also in Europe, where it is a native.

Western Stickseed (Lappula floribunda, (Lehm.) Greene).-A biennial or perennial from one to two feet high; leaves oblong to linear-lanceolate, pubescent; flowers in erect racemes, pale blue; nutlets keeled and with a row of subulate prickles. Common in the Rocky Mountains. Beggar's lice (L. virginiana, (L.) Greene) has stems two to four feet high, with ovate-oblong or oval stem leaves, petioled; pedicels short, deflexed in fruit; nutlets curved by flattened barbed prickles. Common in the North.

Yellow Burweed, Fireweed or Yellow Tarweed (Amsinckia intermedia, F. and M.).-A hispid, erect annual, one to two feet high, with oblong, ovate to linear leaves, lower sometimes lanceolate; yellow flowers in a loose spike or raceme; the bristles of the calyx whitish or merely yellowish; corolla tube slightly longer than the narrow, linear calyx lobes; anthers oblong; nutlets not half the length of the calyx lobes. In dry open grounds in eastern California.

Corn Gromwell, Puccoon (Lithospermum arvense, L.). -A small annual or winter annual with erect stems six to twelve inches high, somewhat rough with minute hairs; leaves lanceolate or linear; corolla funnel-form, regular, white, five-lobed; calyx five-parted; stamens inserted on the tube of the corolla; style one; fruit fourseeded, like one-seeded nutlets. Found on sandy banks and roadsides. Naturalized from Europe. The perennial hoary puccoon (L. canescens), softly pubescent, with sessile, oblong, linear or linear-oblong leaves, yellow flowers and white nutlets, is common from New England, 
and the Mississippi Valley to Arizona. The rough puccoon (L. hirtum) is hispid with bristly hairs; leaves of the stem lanceolate or linear, of the flowering branches ovateoblong, bristly ciliate ; flowers peduncled, crowded, showy yellow. In sandy soils, especially pine barrens from $\mathrm{New}$ York to Minnesota and Nebraska.

Blueweed (Echium vulgare, L.).-An erect, rough, bristly biennial, eighteen inches to two feet high, with an erect, mostly simple stem; leaves of the stem linearlanceolate, sessile; flowers in cymose clusters; corolla reddish purple, changing to blue; tube funnel-form, border unequal, spreading, five-lobed; stamens five, inserted on the tube; style threadlike; nutlets roughened or wrinkled. A common weed along roadsides, fields, and meadows from New England to Indiana.

Verbena Family (Verbenaceae).-Herbs, shrubs or trees with opposite or alternate leaves; perfect, regular or somewhat irregular flowers borne in spikes, racemes or panicles; calyx generally persistent, inferior, four to five-lobed or cleft; corolla four to five-cleft, tube cylindrical; stamens four, didynamous, or two; ovary superior, two to four-celled or more; fruit dry or drupaceous, splitting into one to four nutlets. A large order, found chiefly in tropical regions, and contains about $\mathrm{I}, 200$ species.

Hoary Vervain (Verbena stricta, Vent.).-A downy, simple or branched perennial from one to three feet high; leaves sessile, obovate or oblong, serrate, covered with soft hairs; flowers in long hairy spikes, large, purple; calyx tubular, salver-form; fruit splitting into four seedlike nutlets. Common in sandy soil, knolls and especially upland pastures in the West. The blue vervain ( $V$. hastata), a perennial from four to six feet high with lanceolate or oblong-lanceolate, taper-pointed leaves; blue flowers in linear spikes, is common in low grounds. The narrow-leaved verbena ( $V$. angustifolia) is a simple or somewhat branched perennial; leaves narrowly lanceo- 
late with tapering base and but slightly toothed margins; spikes few; flowers purple. In sandy fields, especially southward and as far north as Minnesota. The white vervain ( $V$. urticaefolia) is a minutely pubescent perennial from three to six feet high; leaves oval; flowers white in slender spikes.

Mint Family (Labiatae).-A few shrubs and trees, but chiefly aromatic herbs, with square stems; opposite leaves without stipules; flowers with cymose inflorescence; perfect, irregular, more or less two-lipped, the upper lip three-lobed, the lower two-lobed or entire; calyx fivetoothed or five-lobed; corolla four to fivelobed, commonly two-lipped, upper twolipped or entire, lower usually three-lobed; stamens borne on the corolla tube; ovary superior, deeply four-lobed or four-parted, in fruit forming four small seedlike nutlets or achenes surrounded by the persistent calyx; usually exalbuminous or some with albumen. A large order of about 3,000 species of very wide distribution.

Germander or Wood Sage (Teucrium canadense, L.).-A downy, erect perennial

Fig. $\quad \times 37$. one to three feet high, with lanceolate to Hoary vervain ovate-lanceolate leaves, serrate, rounded at ( $V$ e $r \quad b \quad e n a$ the base, short petioled, and hoary understricta).

neath; flowers in spikes; calyx fivetoothed; corolla five-lobed, upper lobes nearly equal, the lower lobe larger, all pale purple or rose color; stamens four, exserted. Common in fields, especially in low grounds from New England to Manitoba and Texas; abundant in Iowa, Minnesota and Missouri. Another species ( $T$. occidentale) has viscid hairs on the calyx and flowers somewhat darker in color than the preceding. Common in low grounds in Iowa and Nebraska and is 
found as far south as New Mexico and west to California.

Horehound (Marrubium vulgare, L.).-A whitish, woolly, bitter, aromatic perennial with branched, ascending stems; leaves petioled, round-ovate, pointed, crenatetoothed; flowers in whorls; calyx with recurved, spiny teeth; corolla small, white, upper lip erect; stamens four, included in tube of corolla. Occasionally eastward. Common in Colorado and Utah and the Pacific coast. Very common in the foothills adjacent to the Salt Lake Basin.

Catnip (Nepeta Cataria, L.).-A perennial, erect herb, one to three feet high; leaves ovate, cordate, coarsely serrate, petiolate, whitish, downy underneath; flowers in cymose clusters; corolla whitish, dotted with purple. Native to Europe; widely naturalized in the northern states.

Ground Ivy (Nepeta hederacea, (L.) Trevisan).-A creeping, trailing perennial, with leaves all alike; petioled, round, kidney-shaped, crenate, smooth, green on both sides; flowers light blue in axillary whorls of about six, appearing in early spring and summer. $\mathrm{Na}$ -

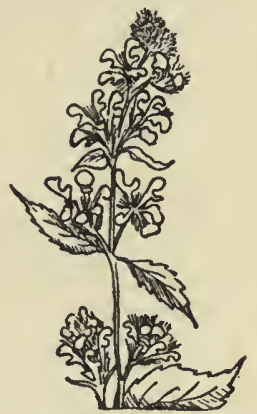

Fig. 138. Dead nettle (Lamium album). Sometimes a very troublesome weed. (Ada Hayden.) tive to Europe, widely naturalized in the northern states, especially in shady places.

Dead Nettle (Lamium amplexicaule, L.).-An annual herb with rounded, deeply toothed, crenate leaves; the upper leaves small, clasping; calyx tubular, five-toothed; flowers small; corolla purple, upper lip bearded, the lower spotted. Common in the eastern states to Missouri. The Lamium album troublesome in the East.

Motherwort (Leonurus cardiaca, L.).-Tall, perennial herb with erect stem, two to six feet high; leaves longpointed, the lower round and palmately lobed, the upper crenate at the base, three-cleft; flowers pale purple in 
close axillary whorls; corolla bearded. Native to Europe, widely naturalized in the northern states.

Peppermint (Mentha piperita, L.).-Smooth, erect, perennial herb with creeping rootstocks from one to two feet high; leaves petioled, ovate, oblong to oblong-

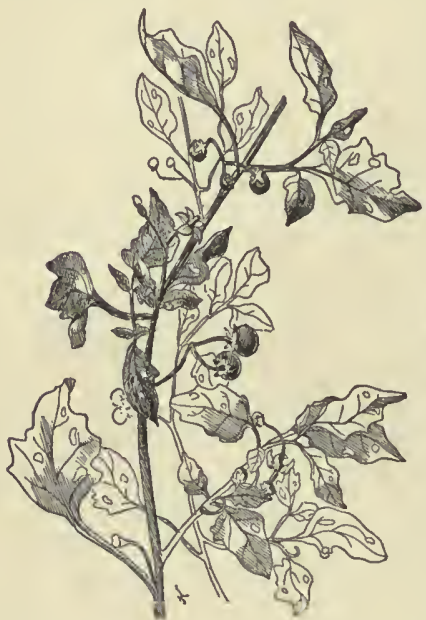

Fig. 139. Black nightshade (Solanum nigrum). lanceolate, acute and sharply serrate; flowers whorled in interrupted, loose, 1 e a fle s s spikes; purplish or whitish. Commonly escaped from cultivation and troublesome in the East.

Nightshade Family (Solanaceac).- Herbs or vines, rarely shrubs; alternate leaves, sometimes opposite, in pairs and unequal (in a few of the tropical species, alternate without stipules); flowers regular or nearly so, borne in cymes; calyx inferior, fivelobed; stamens as many as the lobes of the corolla and alternate with them, inserted on the tube, generally equal; style and stigma one; placentx in the axils; ovules numerous; fruit a berry or capsule. A large family, chiefly tropical, consisting of 70 genera and $\mathrm{r}, 600$ species, several of these being important medicinal plants and others valuable food plants.

Common Nightshade or Stubbleberry (Solanum nigrum, L.).-Annual, low-branched and often spreading; glabrous or hairy, hairs simple, roughened on the angles; leaves ovate, petioled, flowers white, in small, umbel-like drooping lateral clusters; calyx spreading, the lobes obtuse, much shorter than the white corolla; berries glabrous, black, occasionally large. Found in northern 


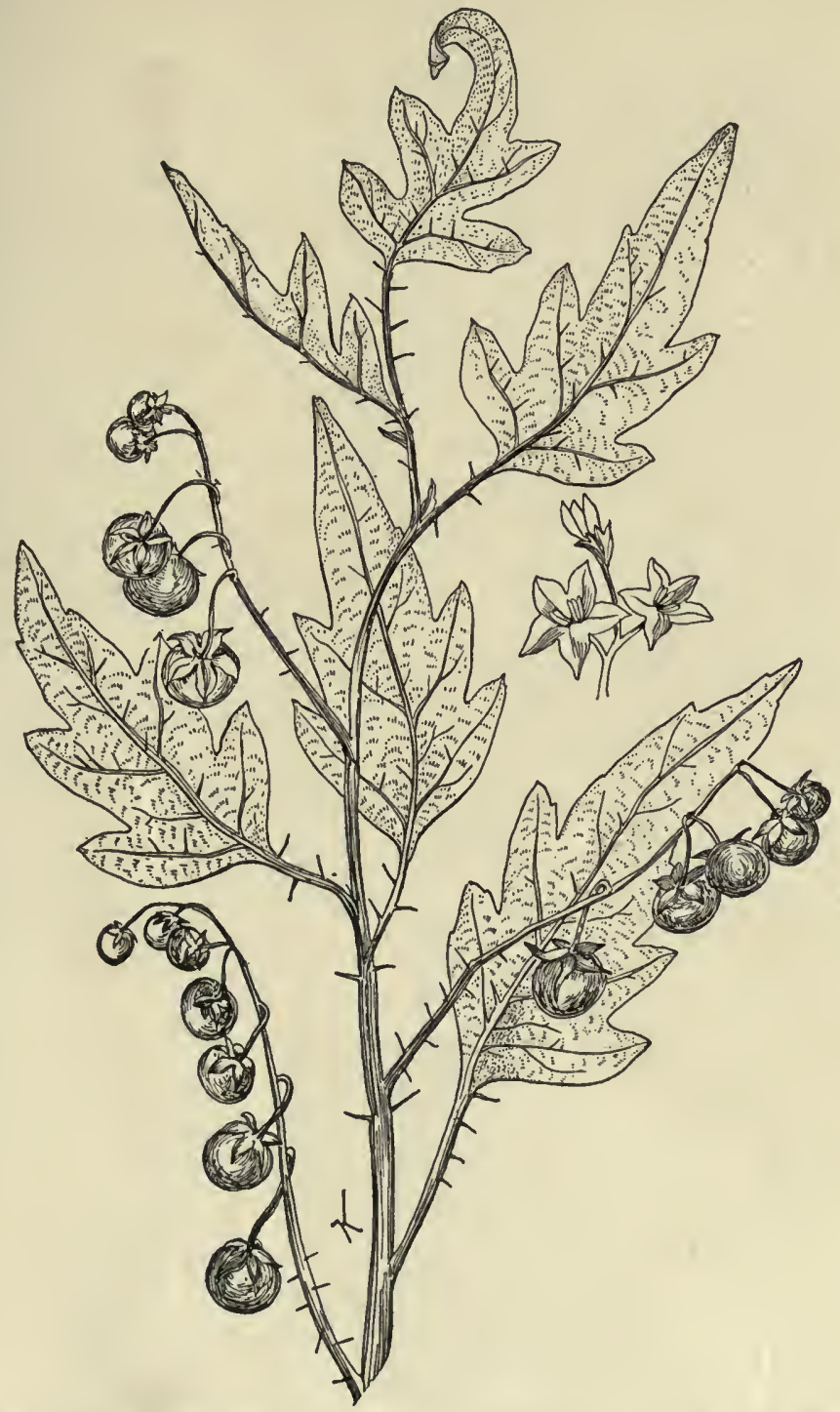

Fig. 140. Horse nettle (Solanum carolinense). A most troublesome persistent weed with deep perennial root. (C. M. King.) 
part of the United States, also in Europe, in shady grounds and fields; a cosmopolitan weed.

Horse Nettle (Solanum carolinense, L.).-An herbaceous, deep-rooting perennial which propagates very freely b.y means of its deep underground roots, the running roots being frequently three feet long; stem from one to two feet tall, somewhat straggling and half shrubby at the base; rather rough and beset with numerous minute, star-shaped hairs and yellowish prickles; leaves two to four inches long, oblong or ovate, sinuatetoothed, lobed or deeply cut, and bearing spines; flowers borne in racemes which later become one-sided: calyx with slender lobes, corolla white or light blue, about oneinch in diameter, resembling that of the common potato; flowers followed by roundish berries one-half to threefourths inch in diameter. Somewhat widely scattered in central and eastern Iowa and at various points in Iowa; common in the South. Berries said to be poisonous, but not likely to cause trouble, since sheep, horses, and cattle refuse to eat them.

Horseweed, Bull Nettle (Solanum eleagnifolium, Cav.). -A deep-rooted, spreading perennial from one to three feet high; stem silvery canescent, finely pubescent; leaves lanceolate, oblong or linear, petioled, entire or repand dentate; flowers in cymose clusters; peduncle stout and short; corolla gamopetalous, blue; calyx lobes lanceolate; berry yellow, smooth, globose. Common on the prairies of Kansas to Texas and New Mexico.

Wright's Datura (Datura Metel, L.).-A spiny pubescent annual, pale in color, leaves obovate, entire; flowers large, showy, white or pale violet, sweet scented; corolla with a five-toothed border; capsule nodding, spiny. In waste places, escaped from gardens from Rhode Island to Florida.

Purple Thorn Apple or Purple Stramonium (Datura Tatula, L.).-A glabrous annual from a few inches to five 
feet high; stem purplish; leaves thin, ovate, acute or acuminate; flowers consisting of a five-toothed calyx and a five-lobed funnel-form corolla, stamens included, filiform filaments inserted below the middle of the corolla tube; capsule globular, prickly, four-valved and two-celled. Abundant in fields and waste places from New England to Ontario to North Dakota, Nebraska, Texas and Florida; naturalized from tropical America. The Datura Stramonium of the same distribution has a green stem and a white corolla.

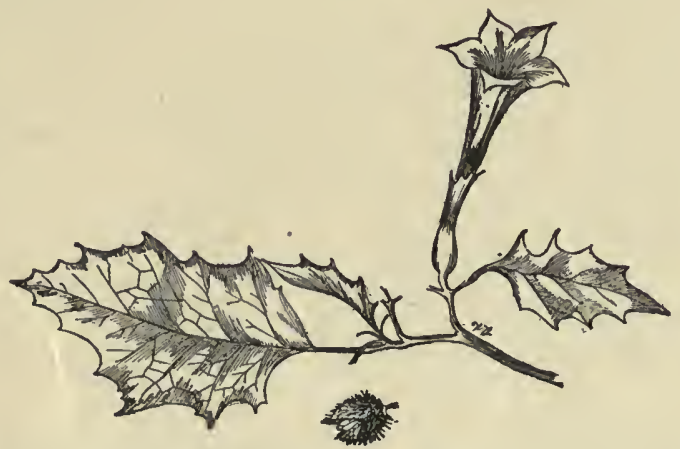

Fig. I40a. Purple thorn apple (Datura Tatuia). Common around barns and roadsides. (Ada Hayden.)

Figwort Family (Scrophulariaceae).-Mainly herbs with a few shrubs and trees; leaves without stipules; flowers perfect, regular or irregular; calyx four to fivetoothed, cleft or divided; corolla irregular, two-lipped or nearly regular; stamens two to five, didynamous or nearly equal, inserted on the corolla; pistil one, twocelled, many ovuled; fruit a capsule; seeds numerous, with a small embryo in copious albumen. About 2,500 species of wide distribution; few, however, of economic importance, although several are medicinal. Among the latter are foxglove (Digitalis purpurea) and mullein (Verbascum Thapsus). 
Great Mullein, Velvet Dock (Verbascum Thapsus, L.). -A tall, densely woolly annual from two to six feet high; leaves oblong, thick, covered with branched hairs, the basal leaves margined petioled; flowers in long, dense spikes; corolla rotate, yellow or rarely white; stamens unequal, the three upper shorter, woolly with short anthers; the two lower smooth with larger anthers. From Nova Scotia north across the continent, south to Missouri and Kansas and west to Utah.

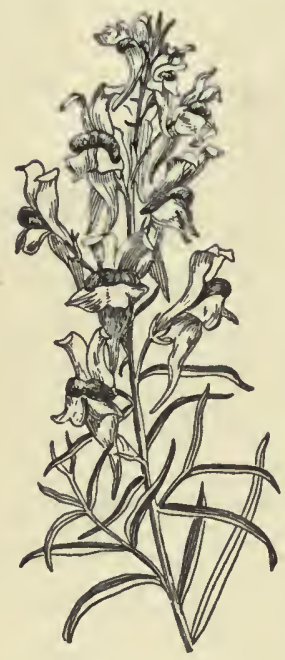

Fig. 14I. Toadflax (Linaria vulgaris.)

Moth Mullein (Verbascum Blattaria, L.).-Stem round, sparingly branched, biennial with smooth leaves, the lower petioled, oblong, ovate, lanceolate, laciniate, serrate, upper clasping ; flowers in loose racemes, yellow or white with a tinge of purple; all stamens bearded with violet hairs; capsule nearly globose; seeds numerous. Common eastward, rare in the Mississippi Valley; abundant in the West in Salt Lake Basin.

Toadflax, Butter and Eggs (Linaria vulgaris, Hill).-A smooth, erect, perennial herb, one to three feet high; leaves numerous, linear or nearly so, subalternate, pale; raceme dense, of yellow flowers, corolla one inch or more long, with a spur at the base; upper lip erect, two-lobed, lower threelobed; calyx five-parted; stamens four, didynamous, not exserted; fruit a capsule, opening by one or more holes in the top; seeds small, numerous, winged. Fields and roadsides. Naturalized from Europe.

Purple Foxglove (Digitalis purpurea, L.).-Biennial or annual pubescent herb with stout stem; lower leaves ovate or ovate-lanceolate, slender-petioled, upper leaves 
smaller, sessile; flowers purple, borne in long drooping racemes; corolla spotted. Native to Europe, but widely naturalized in the Pacific Northwest.

Purslane, Speedwell, Neckweed (Veronica peregrina, L.).-Glabrous, glandular, or nearly smooth, branching annual; floral leaves like those of the stem but reduced; flowers axillary and solitary, white; capsule orbicular. A common weed in fields in eastern North America from Nova Scotia to Florida, Missouri, Kansas and Texas. Also in South America and in Europe, almost cosmopolitan.

Broom-rape Family (Orobanchaceae).-Low, thick, fleshy herbs, destitute of leaf green, with parasitic leaves reduced to alternate scales; flowers perfect, irregular, sessile, solitary or on terminal, bracted spikes ; calyx persistent, four to five-toothed or four to five-cleft; corolla gamopetalous, more or less two-lipped; stamens five, didynamous, inserted on the tube of the corolla and alternate with its lobes, occasionally a fifth rudimentary stamen; ovary superior, one-celled; ovules numerous; embryo minute. About 200 species of wide distribution, one species in the West being a common parasite on sage.

Broom Rape (Orobanche minor, Sm.).-A parasitic, pubescent herb, pale yellowish brown in color; five inches to one foot in height; flowers loosely spicate, purplish tinged; calyx cleft; corolla two-lipped. Introduced from Europe; parasitic on clover on the coast. O. ramosa, L., is much like the preceding, but more slender and more freely branched; flowers light blue or yellow. Introduced from Europe. Parasitic on tomato in New Jersey and on hemp and tobacco.

Plantain Family (Plantaginaceae).-Mostly stemless herbs, with alternate, or opposite leaves in species having stems; flowers small, polygamous or monoecious; calyx four-parted, persistent ; corolla four-lobed, hypogynous; stamens four or only one, inserted on the throat 
or tube of the corolla; ovary one to two-celled, or falsely two to four-celled, sessile; ovule one to several in each cavity; fruit a pyxis, circumscissile at or below the middle, or a nutlet; seeds with a mucilaginous testa. Of the three genera of this family, two are native to North America. More than 200 species of wide distribution.

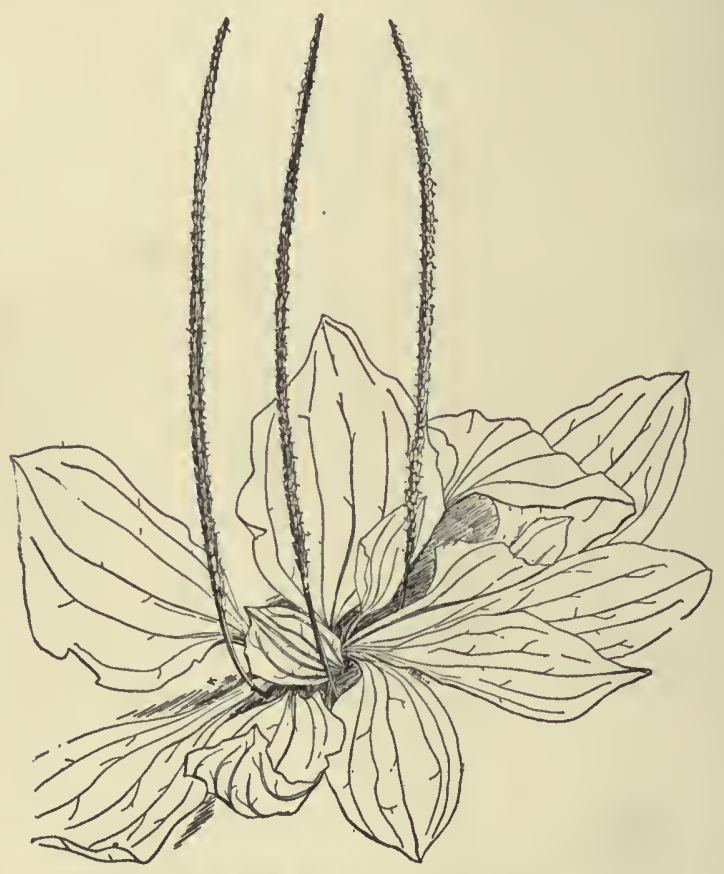

Fig. I42. Rugel's plantain (Plantago Rugelii).

Common Plantain (Plantago major, L.).-A smooth perennial or biennial, sometimes hairy, rarely roughish; leaves ribbed, ovate, oblong, oval or slightly heart-shaped, narrowing into a channeled petiole; flowers in a dense spike, parts in fours; sepals round-ovate or obovate; corolla salver form, withering on the pod; fruit an eight 
to eighteen-seeded capsule, opening transversely, so that the top falls off like a lid and the loose partition which holds the seed falls away; seeds angled, reticulated. A common weed, found everywhere, especially along the waysides and near dwellings. Naturalized from Europe.

Rugel's Plantain (Plantago Rugelii, Decaisne).-Leaves paler and thinner than in $P$. major; flowers borne on long, thin spikes which become attenuated at the end; sepals oblong, acutely keeled; capsules opening below the middle, four to nine-seeded. Maine and Ontario to Minnesota and Kansas and southward to Florida and Texas.

Rib Grass or Buckhorn (Plantago lanceolata, L.).-A pubescent perennial or biennial with a short, erect rootstock; leaves narrowly oblong-lanceolate, somewhat shorter than the scape, and three to fiveribbed; scapes slender with dense spikes, at first capitate, later becoming cylindrical; bracts and sepals dry and brownish; sepals four, persistent; corolla smooth; seeds two in each division. Introduced

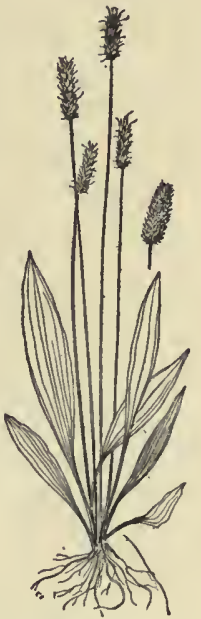

Fig. $\quad 13$. Buckhorn (Plantago lanceolata). largely by means of its seed, which is frequently an impurity in clover seed. Also known as ribwort, ripple grass, plantain and English plantain; a troublesome weed in the clover fields of the eastern states and becoming increasingly common to Iowa fields. Bracted plantain ( $P$. aristata) has narrow, linear bracts, two to six times as long as the flowers; loosely hairy, but later becoming smooth. Dry plains and prairies from Illinois to Louisiana and westward; naturalized eastward on the coast.

Madder Family (Rubiaceae).-Trees, shrubs, or herbs with entire, simple, opposite or whorled leaves; flowers often dimorphous; calyx teeth adherent to the ovary; 
corolla, funnel form, campanulate, four to five-lobed; stamens as many as the lobes of the corolla, inserted on the tube or throat; ovary one to ten-celled; fruit a capsule, berry or drupe. About 5,500 species mostly tropical. Bedstraw (Galium) and coffee belong to the order.

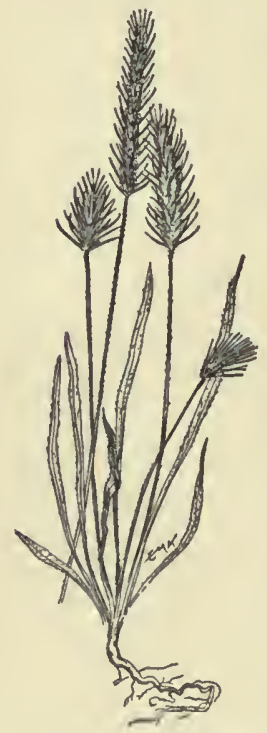

Fig. 144. Bracted plantain (Plantago aristata).

Buttonweed (Diodia teres, Walt.).A hairy, or minutely pubescent annual, with spreading stem; leaves mostly terete, linear-lanceolate; sessile, rigid flowers, one to two in each axil; corolla funnel-form, small; fruit obovate, turbinate, not furrowed, crowned with four short calyx teeth. Common in New Jersey and found as far south as Florida and Texas.

Honeysuckle Family (Caprifoliaceae). - Shrubs, trees or vines, or rarely herbs, with opposite leaves; stipules absent or present ; flowers perfect, mostly cymose; calyx adnate to the ovary, three to fivetoothed or three to five-lobed; corolla gamopetalous with a five-lobed limb or two-lipped; stamens four to five, inserted on the tube of the corolla and alternate with its lobes; ovary two to five-celled; styles slender; stigma capitate; fruit a berry, drupe or pod; seeds with a membranous or hard coat. About 275 species. Found generally in the northern hemisphere.

Indian Currant, Coralberry (Symphoricarpos orbiculatus, Moench.).-A shrub two to four feet high, purplish, usually pubescent, branched; leaves oval or ovate, entire or undulate, nearly glabrous above, pubescent underneath; flowers in short axillary clusters; corolla bellshaped, sparingly bearded, pinkish, stamens included; fruit a purplish berry. Rocky woods and along streams 
from New Jersey to Illinois, Southern Iowa, South Dakota, Nebraska and south to Texas and Georgia.

Campanula Family (Campanulaceae).-Herbs with nilky juice, alternate leaves; regular flowers calyx adherent to the ovary; corolla five-lobed, bell-shaped; stamens five, usually free from the corolla and distinct; style one with hairs near the end; stigmas two or more; fruit a capsule, two or more-celled, many seeded; seed small, anatropous; embryo straight. Represented by the common harebell (Campanula rotundifolia) and several cultivated species, among them $C$. rapunculoides.

Venus' Looking-glass (Specularia perfoliata. (L.) A. D C.).-A somewhat hairy annual, with roundish or ovate, clasping leaves, base heart-shaped; flowers sessile, solitary or a few in the axils of the leaves; calyx in earlier flowers three or four-lobed or parted, in later flowers four or five-lobed; corolla five-lobed or parted in the later flowers, rudimentary in earlier flowers; ovary three-celled, ovules numerous; seeds small, lenticular. Common in dry woods, sandy soil from New England to Mexico and Oregon.

Thistle Family (Compositae, Adans.).-Herbs or rarely shrubs; flowers borne in a close head on the receptacle, surrounded by an involucre of a few or many bracts; anthers usually united into a tube, syngenesious. sometimes caudate; calyx adnate to the ovary, limb crowning the summit in the form of capillary or plumose bristles or chaff called the pappus; corolla tubular or strap-shaped-when tubular, usually five-lobed, ligulate, or bilabiate in one small division of the family; flowers of the head may all be alike, in which case they are called homogamous, or of two kinds (heterogamous); bracts or scales often present on the receptacle; flowers inside the rays are called disk flowers, and a flower without rays is said to be discoid; the five, or rarely four, stamens are usually united into a tube (syngenesious); style two-cleft at the 
apex, or in sterile flowers, usually entire ; fruit a dry, indehiscent achenium containing a single seed without endosperm. The largest order of flowering plants consisting of 840 genera and I3,000 species and found in all parts of the world. Sometimes divided into the sub-families Cichoriaceæ, Ambrosiaceæ and Compositæ.

Ironweed (Vernonia noveboracensis, Willd.).-A rather tall perennial herb, with leafy stem; leaves long-lanceo-

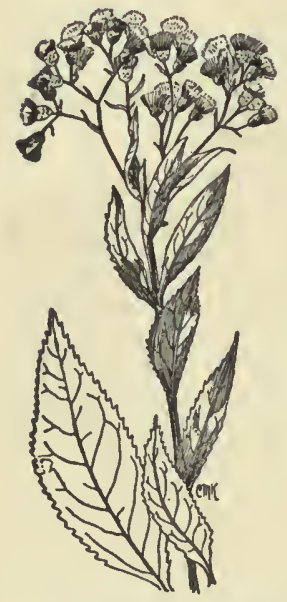

Fig. 144a. Ironweed (Vernonia Baldwinii). late to lance-oblong; heads discoid in open cymes; scales of involucre usually purplish, ovate or lance-ovate, tipped with a slender cusp or awn; flowers purplish. From New England to Minnesota and Kansas. $V$. altissima is a tall perennial, with heads in loose cymes; scales of involucre obtuse or mucronate; flowers purplish. Occurs from Pennsylvania to Missouri and southwest. V. Baldwinii is a minutely hairy plant with small heads; leaves lance-oblong or ovate; scales of involucre acute or acuminate; flowers purplish. Occurs from Minnesota to Texas. $V$. fasciculata has crowded linear or oblong-lanceolate leaves; heads many flowered; flowers purplish. Found in low grounds.

Thoroughwort (Eupatorium serotinum, Michx.).- A branched perennial with pubescent stems, three to seven feet high; leaves ovate-lanceolate, triple-nerved, coarsely serrate; heads in broad cymose clusters seven to fifteenflowered; scales of involucre pubescent; flowers white, common southward, also in Iowa, Missouri, Kansas and from Texas east to Florida and Delaware. The white snakeroot (E. ageratoides) is a smooth, branching perennial with broadly ovate, pointed leaves; compound 
cymose clusters; heads with white flowers.

Common in woods in the Mississippi Valley, east to New Brunswick. Boneset (E. perfoliatum) having lanceolate, connately perfoliate, wrinkled, downy leaves and white flowers is found in marshes, especially in the North. The Joe pye weed (E. purpureum) occurs in similar places. It has tall, stout stems; whorled leaves; and purple flowers, and is found chiefly northward. The mist flower ( $E$. coelestinum), with opposite, petioled, ovate leaves and blue flowers, is common in the South.

Gumweed (Grindclia squarrosa, (Pursh) Dunal.).-A resinous, viscid, glabrous perennial from one to three feet high; leaves alternate, spatulate to linear-oblong, sessile or clasping, spinulose, serrate; heads many-flowered; ray flowers yellow, pistillate; scales of the involucre hemispherical, imbricated in several rows with green tips; achenes short and thick; pappus consisting of two or three awns. Common west of the Missouri River from Mexico, Nevada and Texas, north to British America and east to Minnesota, Illinois and Missouri, occasionally as far as New Jersey.

Goldenrod (Solidago canadensis, L.).-A perennial with rough stem, from three to six feet high; leaves hairy beneath, rough above, lanceolate and pointed, sharply serrate; heads small, few flowered; rays yellow, short pistillate; scales of the involucre appressed, not herbaceous; receptacle small, not chaffy; achenes ribbed; pappus simple, of capillary bristles. Widely distributed from New Brunswick to Florida; common in pastures and borders of fields in the Rocky Mountains to the Northwest Territory and Arizona.

White Aster (Aster cricoides, L.).-A smooth or sparingly hairy perennial from one to three feet high; lower leaves oblong-spatulate, toothed, the upper linear-lanceolate or linear-awl-shaped; heads small in racemes; scales of the involucre nearly equal with awl-shaped, green 
tips; ray flowers white. In dry, open fields and roadsides from New England to Minnesota. The small-flowered white aster (A. multiflorus) is a pale, pubescent, branching perennial one foot or more tall; leaves small and rigid, crowded and spreading with ciliate margins, the

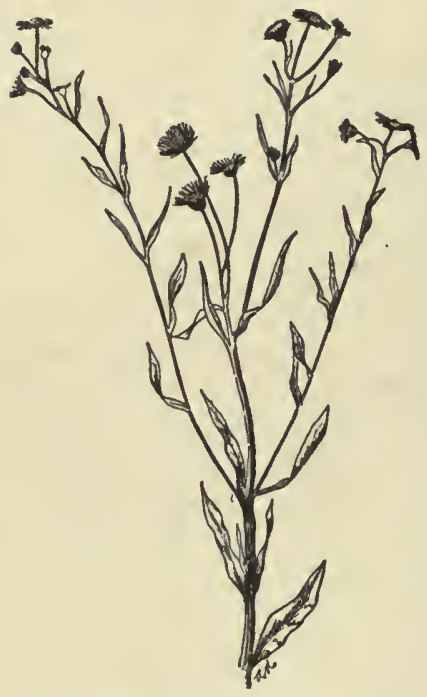

Fig. 145. Whiteweed(Erigeron annuus). upper small and scalelike; heads small; ray-flowers white. Abundant along roadsides and in dry soil in the northern states. The New England aster (A. novaeangliae) with violet-purple ray-flowers is common in low grounds. A large number of species in the United States, but few of them are troublesome weeds.

Willow-leaved Aster (Aster salicifolius, Ait.).-This aster is a tall plant with flowers in racemose clusters, purplish to white. It is common westward, sometimes a troublesome weed.

Whiteweed, Fleabane (Erigeron ramosus, (Walt.) B. S. P.).-Stem and leaves somewhat hirsute and hairy, roughish; leaves entire or nearly so; the upper lanceolate, the lower oblong or spatulate; heads borne in corymbose panicles; ray-flowers white and twice as long as the scales of the involucre; achenes small, pappus double, the inner row of fragile bristles. From Nova Scotia, to Florida, west to Louisiana and Texas to Northwest Territory. The E. annuus is a larger, hairy plant, branched above leaves coarsely and sharply toothed. In clover and timothy meadows and woods. 
rorseweed (Erigeron canadensis, L.).-A bristly hairy annual from one to five feet high with erect stems, leaves linear, mostly entire, the root leaves cut-lobed. Heads very numerous, small cylindrical in panicles. A common weed in waste places across the continent, also in Europe. Fields and gardens.

Low Horseweed (Erigeron divaricatus, L.) is a diffuse spreading plant with purple ray-flowers; common in sandy, gravelly soil from Indiana and Nebraska southward; it is sometimes a troublesome weed.

Marsh Elder (Iva xanthifolia, Nutt.).-A tall, rough annual one to eight feet high; leaves opposite and hairy, rhombic, the lowest sometimes heart-shaped, cut-toothed or doubly serrate; flowers in axillary clusters on ample terminal panicles; heads small. crowded; outer bracts of the involucre broadly ovate, greenish; inner membranaceous; achenes smooth. A weed that is recognized as of considerable importance in the corn fields in the western part of the state; occurs frequently in Nebraska, Kansas.and Colorado. In Iowa generally confined to barnyards and railroad embankments.

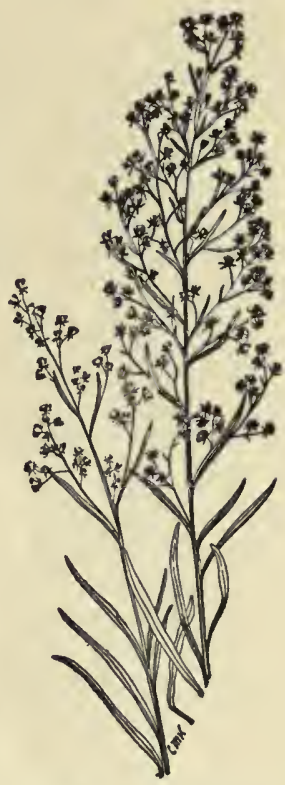

Fig. 146. Horseweed (Erigeron canadensis):

Small-flowered Marsh Elder (Iva axillaris, Pursh).-A smooth or sparingly pubescent perennial with herbaceous stems, from one to two feet high, with woody roots; leaves sessile, entire or nearly so; obovate, oblong or linear-oblong, the lower opposite, the upper smaller and alternate, short petioled; heads generally solitary in the axils of the leaves; involucre hemispherical, pistillate; 
flowers with tubular corolla. Common especially in the saline soils from Nebraska to the Dakotas, British Columbia, California and New Mexico.

Smaller Ragweed (Ambrosia artemisiaefolia, L.).-A branched, hairy annual, growing from one to three feet

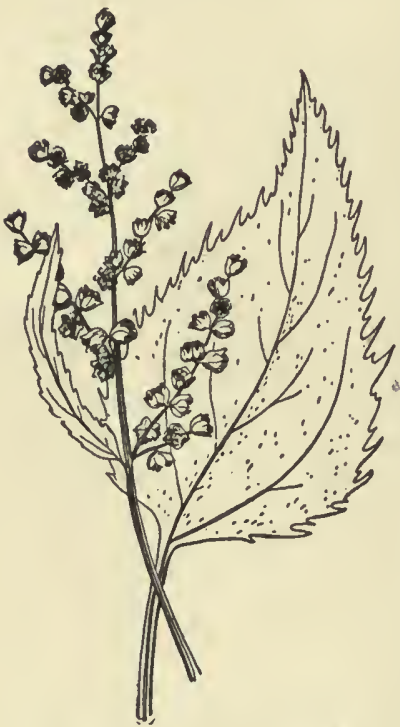

Fig. 147. Marsh elder or half-breed weed (Iva xanthifolia). ('Theo. Holm.)

high, with thin, once to twicepinnatifid leaves, the upper, alternate, the lower usually opposite, pale or canescent beneath; flowers monoecious, the staminate above, the pistillate in the lower axils of the leaves: fertile heads globose or obovoid, short beaked, four to sixspined. A troublesome weed in all parts of the state and very generally distributed throughout the United States.

Greater Ragweed (Ambrosia trifida, L.).--A stout, rough or sometimes nearly smooth annual, three to twelve feet high; leaves opposite, petioled, threenerved, deeply three-lobed, the lobes being ovate-lanceolate and serrate, the upper leaf sometimes ovate and undivided; flowers monoecious, the staminate borne on spikes surrounded by large bractlike leaves; involucre inclosing a single oily, beaked seed, five to seven-ribbed, each rib bearing a tubercle near the summit. Ragweeds produce a large number of seeds, and though the weeds are easily destroyed, the seeds retain their vitality and are readily carried from place to place by drifting snow.

Western Ragweed (Ambrosia psilostachya, D. C.).This perennial ragweed much resembles hogweed, but 
produces slender running rootstocks. It is common in dry soil, especially in the Rocky Mountain country.

White-leaved Franseria (Franseria discolor. Nutt.).An erect, slender perennial from a few inches to a foot in height; creeping roots; lower surface of leaves canescently tomentose; upper surface green and smooth, interruptedly pinnatifid, oblong in outline, large, the lower six inches long, lobes usually broad and short; sterile racemes solitary; fruiting involucres two-flowered, canescent, armed with short straight spikes. Common on the plains from Nebraska to Wyoming, Colorado and New Mexico. F. Hookeriana is a diffusely spreading, hispid or hirsute annual; leaves roundish, one to three inches broad, bi-pinnatifid the upper pinnatifid; sterile racemes solitary; fruiting involucre awned with flat and thin straight spikes. From Saskatchewan to Texas and the Pacific coast. F. tomentosa is one

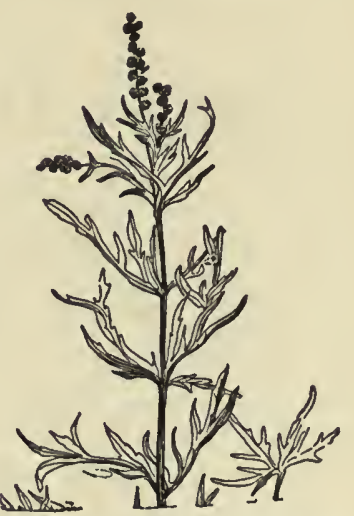

Fig. I48. Small ragweed (Ambrosia artemisiaefolia) (C. M. King.) foot high, rather stout, apparently a perennial ; canescent, densely tomentose; leaves white below, cinerous above, pinnately three to five-cleft; spine of fruiting involucre conical, subulate. Occurs along streams from Kansas to eastern Colorado and southward.

Cocklebur (Xanthium canadense, Mill.).-A coarse, rough annual from one to three feet high, with alternate, cordate or ovate, three-nerved, long-petioled leaves; staminate and pistillate flowers borne on different heads, the involucre of the staminate flowers somewhat flattish of separate scales; receptacles cylindrical; scales of involucre of fertile flowers closed in fruit, two-beaked, con- 
taining two achenes, without pappus; two large prickles at upper end of involucre; bur densely prickly and rough ; each bur contains two seeds which generally germinate

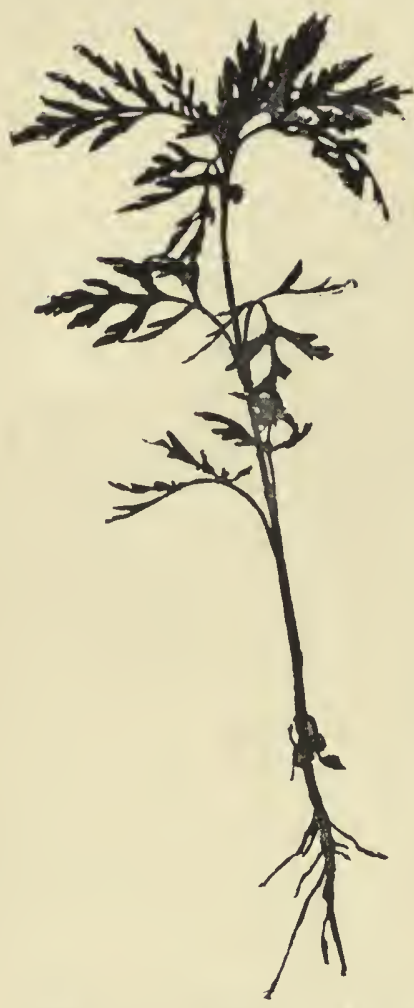

Fig. 148a. Young plant of smaller ragweed. (Am. Steel and Wire Co.) in different seasons. Plant is apt to take possession of worn-out lands, and is frequently found on the alluvial bottom of streams; in Iowa it is very troublesome in some corn fields and in many places is a common street weed. Burs are injurious to stock chiefly because of their mechanical properties, but are said to be poisonous to hogs and many think that the ground where they have grown becomes poisoned.

Clotbur (Xanthium spinosum, L.). - A pubescent, branched annual herb with slender, yellow three-parted spines in the axils; leaves lanceolate or ovate-lanceolate, white, downy underneath; bur oblong, cylindrical, armed with a single short beak and numerous glabrous prickles. Common in waste grounds from Ontario to Missouri and Texas to Florida, but native to the Old World.

Ox-eye (Hcliopsis scabra, Dunal.).-A rough, pubescent perennial with opposite, petioled, triple-nerved leaves; heads large, peduncled; scales of involucre in two to three rows, nearly equal; ray-flowers yellow, ten 
or more, fertile; achenes smooth, thick, four-angled, truncate; pappus chaffy or two to three-toothed. From New York to Wisconsin, Minnesota and British Columbia and southwest to Missouri, Kansas and Arkansas.

Eclipta (Eclipta alba, Hassk).-A rough, annual herb, with oblonglanceolate or linear-lanceolate, opposite leaves; heads small, solitary, and many flowered; $\mathrm{sca}$ les of involucre leaflike; flowers white; achenes short, three to four-sided, hairy at the summit; four-toothed. Native to Asia and found abundantly in the tropics; quite common in the United States.

Coneflower, Niggerhead (Rudbeckia hirta. L.).-A rough, bristly, hairy biennial from one to two and one-half feet high; stem simple or branched near the base,

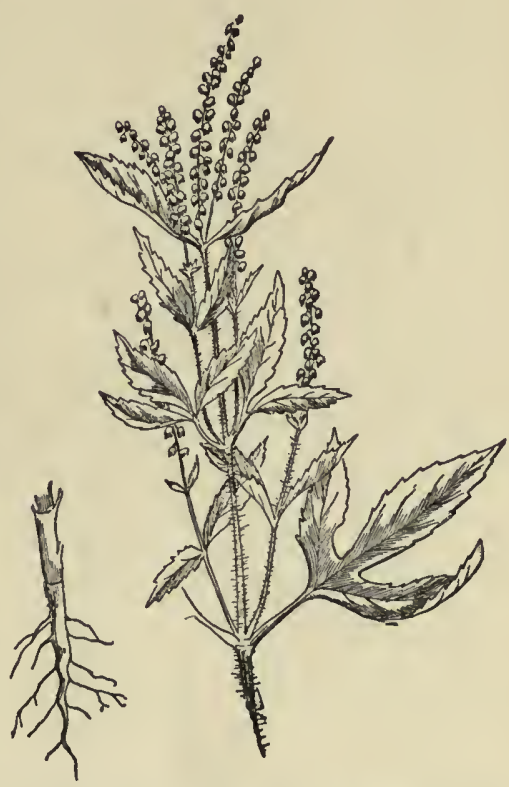

Fig. r49. Greater ragweed ( $A m$ brosia trifida). Common in the West and especially in grain fields of the Dakotas. (Clark-Hayden.)

bearing a long pedunculate head; leaves nearly entire, the upper sessile, oblong or lanceolate, the lower petioled and spatulate; heads many-flowered, radiate, the rays about fourteen, neutral; receptacle columnar or conical; chaff hairy at tip, acutish; ray-flowers yellow, disk dull brown; achenes four-angled; pappus none. Common in dry soils and on prairies and meadows in the eastern states; introduced largely with clover seed. 
Common Sunflower (Helianthus annuus, L.).-A tall, rough annual, six to eight feet high with three-ribbed, ovate, the lower sometimes cordate, serrate leaves; heads large with yellow ray-flowers and brownish disk-flowers.

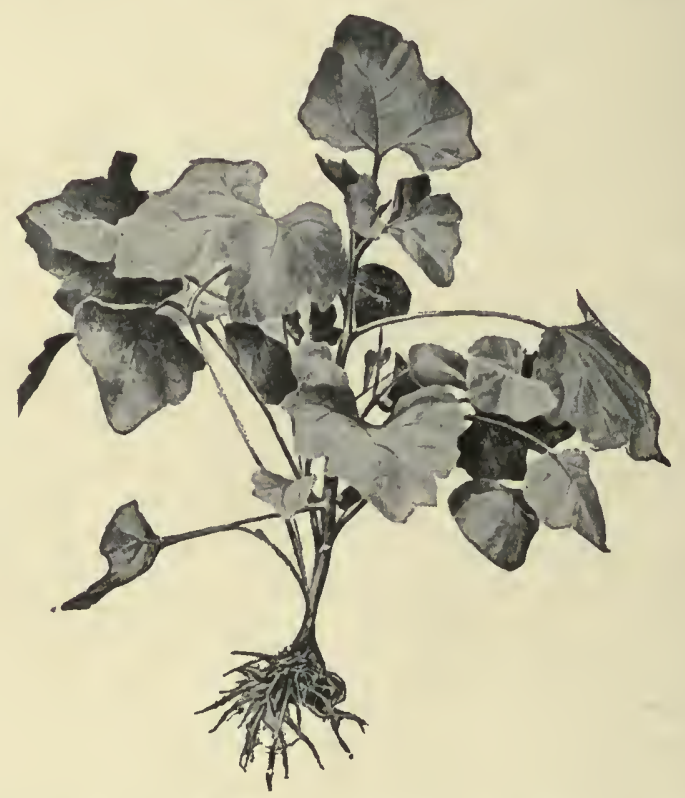

rig 150. Young cocklebur (Xanthium canadense). (Am. Steel and Wire Co.)

Native in the western part of the state and especially troublesome in the alluvial soils of the Missouri River valley. Has been carried to other sections by railroad traffic and is now found in many other states of the Mississippi Valley.

Prairie Sunflower (Helianthus petiolaris, Nutt.).Smaller than the common sunflower, grows from one to three feet high; lower branches somewhat rough; stem leaves one to three inches long, oblong to ovate-lanceolate, sparingly 
toothed; lower leaves abruptly contracted into a long, slender petiole; involucral bracts lanceolate or oblonglanceolate, with acute or mucronate tips; flowers one-half inch or more in diameter. Especially distinguished from two preceding species by character of petiole and the fact that the head is smaller. Found in various parts of Iowa; naturalized in eastern parts of state, especially on Muscatine Island, whither it was probably carried in stock cars.

Meadow Sunflower (Heli anthus grosseserratus, Mar tens).-A tall, smooth perennial six to ten feet high, bearing numerous leaves, short oblong-lanceolate, acuminate with sharp teeth, the upper sometimes merely denticulate, rough above, whitish below; lower stem leaves eight to ten inches long, petiole one to two inches long; heads one-half inch long with deep yellow rays about an inch long;

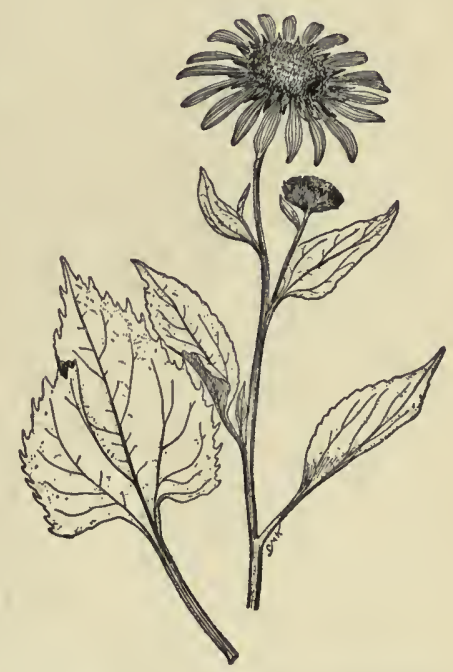

Fig. 151. Common sunflower (Helianthus annuus). bracts of involucre slender.

Common throughout the state, and while at times troublesome in corn fields, especially on low grounds, it usually occurs in swales where there is considerable moisture.

Maximilian's Sunflower (Helianthus Marimiliani, Schrad.)-This plant resembles meadow sunflower; it is stout, often with simple leaves, rigid and scabrous. Heads rather large. Common from Minnesota to Texas.

Beggar-ticks, Stick-tights (Bidens frondosa, L.).-A branching, hairy, or smooth annual, two to six feet high; 
leaves petioled, three to five-divided, the stalked leaflets lanceolate, pointed, coarsely toothed; rays small and yellow; involucre double, outer foliaceous, longer than the head; receptacle flattish, with deciduous chaff; achenes wedge-obovate, two-awned, the awns downwardly barbed. Widely distributed in moist places

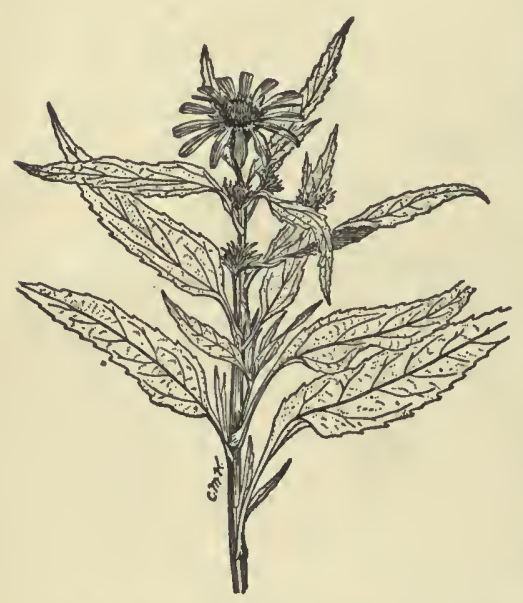

Fig. I52. Meadow sunflower (Helianthus grosseserratus). throughout the northern states; often a very troublesome weed in gardens. Widely scattered because of the seeds adhering to clothing, pelts of animals, etc.

Tickseed (Bidens aristosa, (Michx.) Brit.).-A s mooth, somewhat pubescent annual or biennial; leaves once to twicepinnately compound with five to seven divisions; leaflets $1 \mathrm{ance}$ ol a te; heads in ample clusters; slender peduncles; outer scales not exceeding the inner; ray-flowers conspicuous, golden yellow; achenes cuneate, upwardly ciliate, crowned with two erect, triangular or awl-shaped, stout, upwardly or downwardly barbed awns. From Delaware to Michigan, southern Iowa, Missouri and Louisiana.

Tarweed, California Tarweed (Madia californica, Molina).-A glandular, more or less viscid, heavy-scented annual, one to three feet high; leaves linear or lanceolate, entire or slightly toothed, the upper, at least, alternate; heads racemose or paniculate, often glomerate; ray flowers five to twelve, yellow, disk flowers about the same 
number; achenes obovate-oblong and slightly curved; disk achenes one-nerved down the side. A viscid excretion from this plant injures everything coming in contact with it. Found on Californian coast.

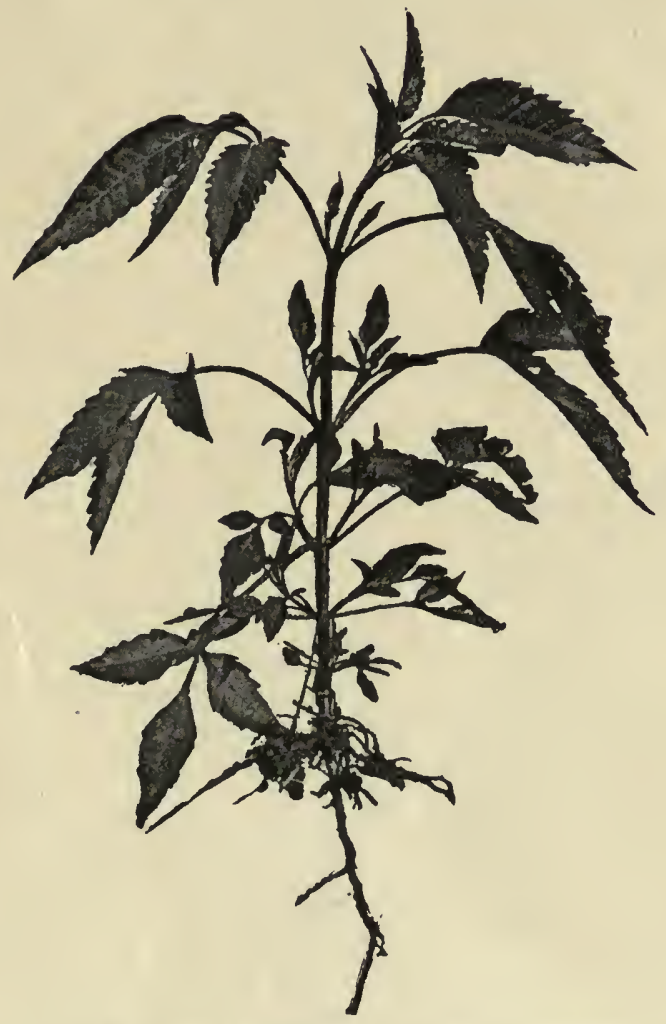

Fig. I53. Young plant beggar-ticks (Bidens frondosa). (Am. Steel and Wire Co.)

Sneezeweed (Helenium autumnale, L.).-A smooth or pubescent perennial one to six feet high; leaves toothed, lanceolate to obovate, oblong, decurrent on the stem, 
acuminate at the apex; heads ntmerous, many-flowered, radiate; rays yellow, wedge shaped, three to five-cleft, fertile; disk-flowers yellow, involucre small, reflexed; scales linear or awl-shaped; receptacle glabrous or oblong; achenes pubescent on the angles; scales of the pappus ovate, acuminate; the variety grandiflorum has

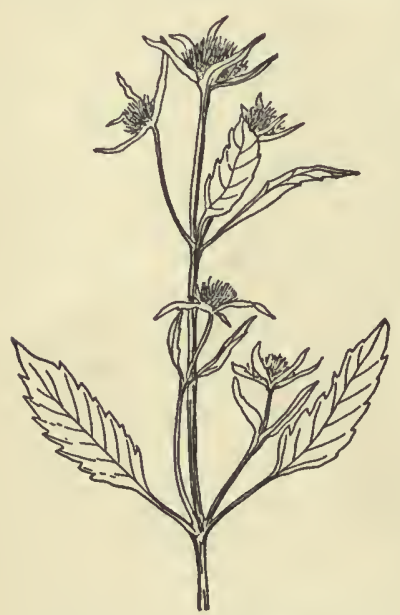
larger heads, scales of the pappus narrower and larger awned. Common in low meadows and alluvial river banks from eastern Canada to Soutl Dakota and from Florida to Alabama; especially common in the northern Mississippi Valley to Kansas.

Narrow-leaved Sneezeweed (Helcnium tenuifolium, Nutt.). - A perennial, erect, branching herb from one and one-half to two and one-half feet high; leaves alternate, decurrent on the stem, linear, filiform; flow-

Fig. 154. Beggar-ticks ers borne in corymbed clus(Bidens frondosa). (C. M. ters; heads many-flowered;
King.)

ray-flowers yellow, fertile, disk-shaped, ribbed; pappus of one-nerved, chaffy scales, the nerve extended into a point. Common from Texas to Missouri, Florida and Virginia, especially in pastures, roadsides and meadows; said to have been widely scattered after the Civil War.

Fetid Marigold (Dysodia papposa, (Vent.) Hitchc.).A nearly smooth, branched annual from six inches to two feet high; leaves opposite, sessile, pinnately parted, bristly toothed, with large pellucid glands, which give to the plant a strong odor; heads many-flowered; rays small, yellow, pistillate; disk yellow; involucre with a 
few scales at the base, one row united to form a cup; achenes slender, four-angled, pappus a row of chaffy scales divided into numerous rough bristles; many seeds. Common from western Iowa and Minnesota to Illinois and the Southwest. In this section of the country it occupies ground like that over-run with mayweed.

Yarrow (Achillca millcfolium, L.).-Perennial herb from one to two feet high; simple stems, leaves twicepinnately parted, consisting of crowded linear divisions; flowers in compound, flat-topped corymbs; heads manyflowered, radiate; rays four to five, white; scales of the involucre with scarious margins; receptacles chaffy; disk flowers small, tubular; achenes oblong, flattened; pappus none. Common from the Atlantic to the Pacific; in the East found in old fields and dry hills; abundant in open parks and rocky dry soils in the Rocky Mountains up to the timber line; native also to Europe where it is used as an ornamental plant; the form with rose-colored rayflowers is also cultivated. Sheep will eat the weed.

Mayweed, Dog Fennel (Anthemis Cotula, L.).-An acrid, branching, strong-scented perennial from one to two feet high with leaves thrice pinnately dissected; heads solitary and many-flowered, ray-flowers white, and pistillate, fertile or neutral; disk-flower yellow, small and tubular; involucre consists of numerous small, imbricated, dry and scarious scales; achenes terete or ribbed, smooth, truncate; pappus none or merely a minute crown. Common in Europe where it is native, but introduced into the United States and very widely spread, being scattered from the Atlantic to the Dakotas and Nebraska throughout the northern states. Also found in Washington and Oregon.

Corn Chamomile (Anthcmis arvensis, L.).-A pubescent annual or biennial closely resembling mayweed, but not so strongly scented; sessile leaves, one to two-pinnately parted; numerous heads with oblong, obtuse 
bracts; achenes obtusely four-angled. Very common on the Pacific coast and in fields and waste places on the Atlantic coast occasionally as far west as Minnesota. The garden chamomile ( $A$. nobilis) is a pleasantly scented, much-branched perennial; bracts of involucre obtuse with broad, rough margins; rays twelve to eighteen; achenes two to three-toothed, oblong and threeangled. In eastern Atlantic states and on the Pacific coast.

Ox-eye Daisy (Chrysanthemum Leucanthemum, L.).A perennial herb, with an erect stem; spatulate, petioled leaves, those of the stem partly clasp-

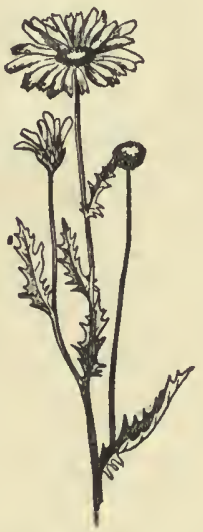

Fig. 154a. Oxeye daisy, so-called (C hry s anthemum Leu(anthemum). A most troublesome weed in eastern meadows. (Ada Hayden.) ing; all leaves cut or pinnatifid-toothed; the nearly simple stem bearing a large, many-flowered head which has numerous white rays; involucre with dry, membranous margins; both disk and ray-flowers produce achenes; so-called seeds marked with longitudinal lines; pappus absent. A troublesome weed in eastern states but only occasionally annoying in the West. This is the ox-eye daisy of American botanists, but according to Fernald is not the European plant. The common form is var. pinnatifidum.

Tansy (Tanacetum vulgare, L.).-A bitter, acrid, strong-scented, simple or branched perennial herb from two to four feet high; leaves pinnately divided into linear pinnatifid divisions, lobes serrate; heads corymbose, many flowered; ray-flowers few, disk-flowers yellow; marginal flowers fertile, scales of involucre imbricated in several series; receptacle flat or convex, naked; branches of style brushlike at the summit; achenes fiveangled or five-ribbed, truncate or obtuse; pappus none or a short crown. Native to Europe, frequently escaped 
from gardens to roadsides along the Atlantic coast and as far west as Iowa and Kansas.

Wormwood ((Artemisia biennis, Willd.).-An aromatic, somewhat bitter, smooth annual or biennial, from one to three feet high, with leafy stems and erect branches; lower leaves twice pinnately-parted, the upper pinnatifid, lobes linear or linear-oblong, serrate or cut-toothed; rayflowers absent; heads numerous in short axillary spikes; bracts of involucre green, scarious, margined. Common in the northern Mississippi Valley; now widely distributed east to Nova Scotia and south to Kentucky.

Western Mugwort (Artemisia Luduviciana, Nutt.).-A branching perennial; leaves and stems white woolly; leaves lanceolate, the upper usually entire, lower cut-toothed; heads in narrow panicles, rayflowers absent; involucre of dry and scarious scales; receptacle naked; flowers small, yellowish; achenes obovoid; no pappus. Common on dry hills from Illinois north to Saskatchewan and southwest to Texas, Colorado and Utah. The common mugwort of Europe (A. vulgaris) closely related to the above species, has the lower leaves glabrous above, white woolly be-

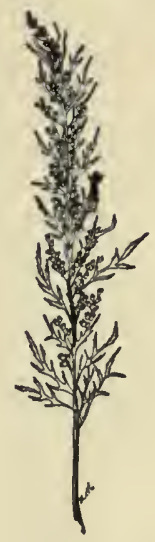

Fig. I 55 . Wormwood (Artemisia biennis). A common weed in the West and North. (C. M. King.) neath and pinnatifid; heads small in open panicles. Naturalized around dwellings eastward. The common sage brush of the West is A. tridentata. Absinth, A. absinthium, is shrubby and finely canescent ; naturalized eastward.

Fireweed (Erechtites hieracifolia, (L.) Raf.).- An erect, coarse annual of rank odor and having a grooved stem, often hairy; leaves alternate, simple, lanceolate or oblong, acute, cut-toothed, the upper with auricled base; heads many flowered; receptacle hooked; flowers tubular 
and perfect; achenes oblong, tapering; pappus of copious, soft, white capillary bristles. Common in moist woods; in the North, also in recent clearings which have been burned over, hence the common name. From New England to Northwest Territory, Kansas, Louisiana and the southern Rockies.

Fig. 156. Fireweed (Erechtites hieracifolia). Common in the North in burnt-over areas. (C. M. King.)

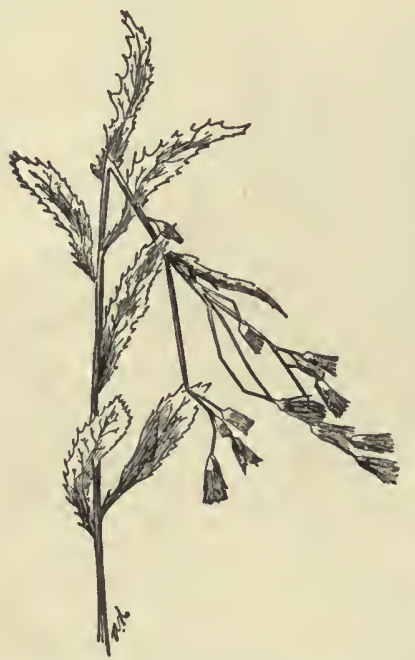

Burdock (Arctium Lappa, L.).-A coarse, branched, hairy biennial from one to three feet high; leaves large, roundish or heart-shaped, thin, obtuse, entire or dentate, tufted or matted with soft hairs on the under side; petioles deeply furrowed; bristles of the pappus unequal; native to Europe, common in gardens, fields and waste places in the northern states, but sometimes cultivated for its root, which is used in medicine.

Bull Thistle (Cirsium lanceo la t $u m$, (L.) Hill.). - A branching perennial, three to four feet high, covered with matted woolly hairs becoming. dark green and villous with age; leaves lanceolate, decurrent on the stem with prickly wings deeply pinnatifid, the lobes with rigid, prickly points, the upper face roughened with short hairs, the lower, cottony; heads one and three-fourths to two inches high; bracts of the involucre lanceolate, rigid when young, more flexible with age; long attenuated, prickly pointed, spreading tips, woolly weblike; flower hermaphrodite, purple; achenes one and one-half inches long, pappus of numerous plumose bristles. This is a trouble- 
some weed along roadsides and in pastures, being most abundant in forest clearings; it has been naturalized from Europe. The seeds germinate in the spring, producing a mass of leaves; the second season, a flowering stem shoots rapidly up, producing flowers and seeds, then dies.

Woolly Thistle (Cirsium canescens, Nutt.).A branching perennial two to four feet tall, woolly throughout, the branches bearing single medium sized heads; stem angled, white woolly; radical leaves, eight to twelve inches long, prominently ribbed, ending in stout spines, the divisions usually twolobed; stem leaves, except the lower, one to four inches long, pinnatifid, the upper sessile, slightly roughened and covered with a slight cottony down, the lower,

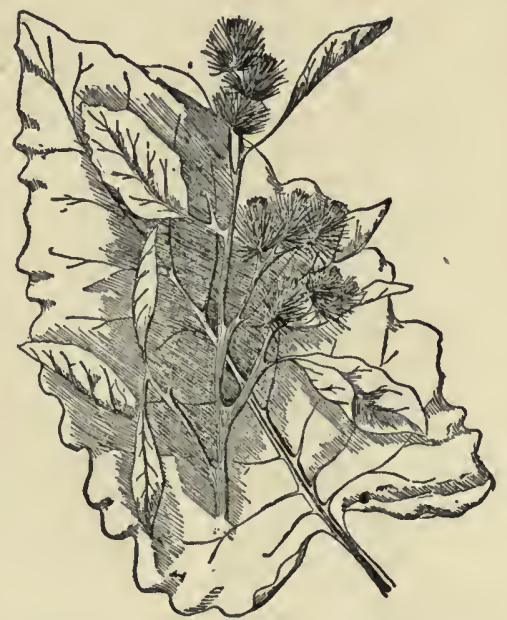

Fig. 157. Burdock (Arctium Lappa). Common in the North across the continent. (Clark-Hayden.) white woolly; heads one and one-half to two inches high, bracts of the involucre somewhat arachnoid, lower scales with a broad base, glutinous ridge, and ending in a minutely toothed spine, inner scales long attenuated, tips straw colored; flowers purple. Minnesota and western Iowa to the west and southwest.

Prairie Thistle (Cirsium discolor, (Muh1.) Spreng.).A tall, branching, leafy biennial, five to seven feet high, with heads larger than those on the Canada thistle; stem grooved, slightly hirsute; radical leaves twelve to four- 
teen inches long, deeply pinnatifid, the divisions frequently divided, prickly toothed, the upper surface smoothish and the lower white and woolly, finely divided stem leaves; single heads one and one-half inches long with purple flowers terminating the branches; bracts of the involucre somewhat appressed, slightly weblike; lower bracts ovate with a broad base and a weak, prickly, recurved bristle, slight rlorsal gland ; inner bracts, linear-lanceolate, with an entire, nearly colorless appendage; flowers Durple, the lobes terminating in cleft tips; anther

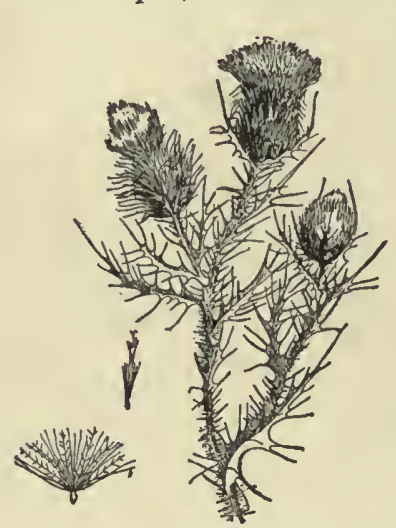

Fig. 158. Bull thistle (Cirsium lanceolatum). Common in pasture, wood lots and roadsides. (Ada Hayden.)

tips acute, filament pubescent; bristles of pappus plumose, achene smooth, upper part yellow. On roadsides and in meadows from New Brunswick westward to Ontario, Minnesota and Iowa.

Canada Thistle (Cirsium arvense, (L.) Scop.).-A smooth perennial, spreading by creeping rootstocks; cory m bos e 1 y branched at the top, growing one to three feet high, smooth; leaves lanceolate, sessile, and deeply pinnatifid, the lobes and margins of the leaves being beset with spiny teeth; heads small, three-fourths to one inch high, bracts pressed closely to head, the outer with a broad base, the inner narrow, all with an acute, never spiny tip; flowers purple, dioecious; all the bristles of the pappus plumose.

The chief points of difference between the Canada thistle and other allied species are as follows: the head is smaller, the involucre or modified leaves surrounding the head is not spiny, but smooth; the leaves are lance- 


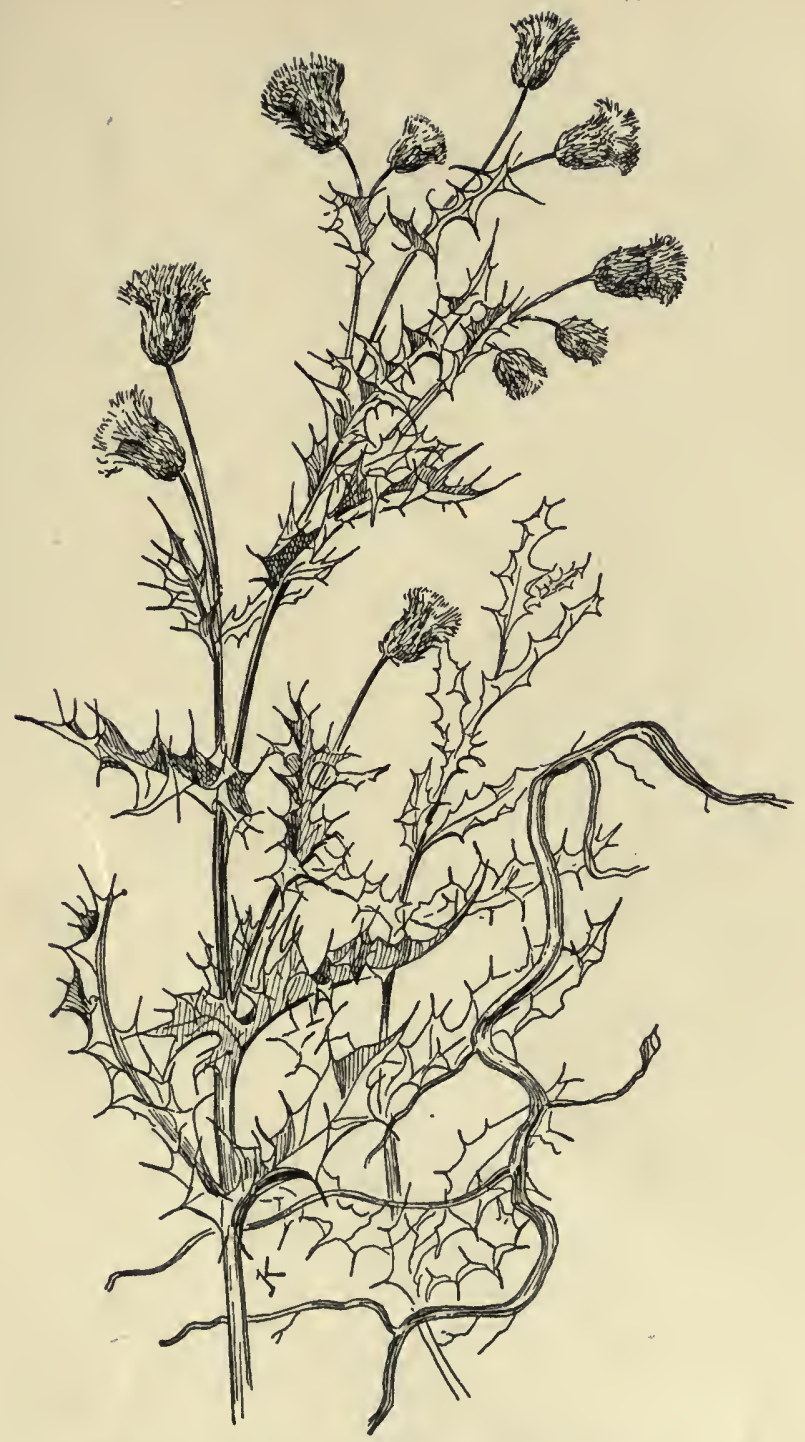

Fig. 159. Canada thistle (Girsium arvense). 
shaped, sessile and deeply divided, the lobes and margins having spiny teeth. Naturalized from Europe. Canada westward and southwest.

Knapweed (Centurea solstitialis, L.).-An erect, branched, annual with cottony winged stem, lower leaves lyrate, upper linear entire, decurrent; spines of upper bracts long spreading with a few smaller ones at the base; flowers yellow, pappus soft.

It is found in fields in the east and south of England, rare; it has been introduced with alfalfa, etc., into the United States.

Black Knapweed (Centaurea nigra, L.).-It is a scabrous perennial, with stiff, branched stems, lower leaves spatulate, dentate or lobed, upper leaves oblong or lanceolate, sessile or partly clasping; the bracts of the involucre are tipped with a fimbriate appendage; flowers are rosepurple; achenes four-sided. It is found on the Atlantic coast. The brown knapweed (C. Jacea) is a perennial, much like the preceding, with entire or denticulate leaves, globular involucre, brown bracts with fimbriate appendages, achenes four-angled. It appears in the East and Northwest on the Pacific coast. Star thistle (C. Calcitrapa) is an annual with pinnatifid leaves, outer bracts of the involucre ovate-oblong, each tipped with a stout spine; flowers purple; achenes compound, obscurely foursided. It appears on the Atlantic coast and in the Pacific northwest, but is native to Europe.

Blue Bottle, Bachelor's Button (Centaurea Cyanus, L.). -A branched annual from one to one and one-half feet high, woolly, tomentose; leaves linear, entire, the lower dentate or pinnatifid; heads many-flowered on long peduncles, involucre ovoid or globose; bracts imbricated, greenish yellow; flowers blue or purplish, varying to white; all tubular, the marginal one neutral, achenes compressed or four-angled; bristles of the pappus un- 
equal; native to Europe, frequently escaped from cultivation in the northern states, but sometimes cultivated as an ornamental plant.

Chicory or Succory (Cichorium Intybus, L.).- A branching perennial with deep roots and alternate leaves; basal leaves spreading on the ground; stem leaves oblong or lanceolate, partly clasping; showy flowers, bright blue, varying in pink or purple. Common along roadsides, in fields and waste places from New England to Canada and Nebraska; especially common where chicory has been cultivated. A troublesome weed in Wisconsin and Minnesota. Allied to endive which is cultivated as a salad plant.

Long-rooted Cat's-ear or Gosmore (Hypochaeris radicata, L.). - Stems several, from a perennial root, slender, one to two feet high; branched or rarely simple, bearing a few scales; leaves oblanceolate to obovate in outline, pinnatifid-lobed to dentate, two to six inches long, hirsute on both sides; involucre about an inch long, glabrous or sparingly pubescent; achenes rough, all with very slender beaks longer than the body. Waste places, western Washington to California. Naturalized from Europe.

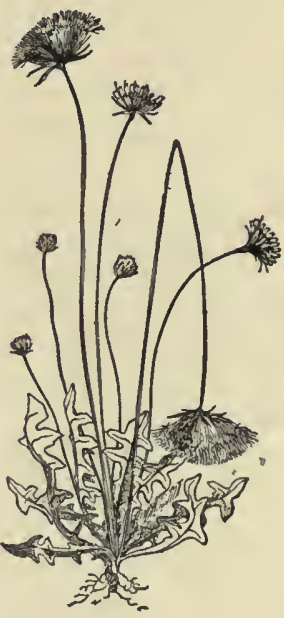

Fig. r6o. Cat's ear (Hypochaeris radicata). (C. M. King.)

Skeleton Weed or Gum Succory (Chondrilla juncea, L.).-A perennial with widely branching stems, one to three feet high, bristly hairy below, smooth above; basal leaves runcinate, pinnatifid; stem leaves few, linear heads few-flowered, short peduncled; involucre glabrous; achenes terete with an abrupt, slender beak, several ribbed, smooth below. Common eastward in fields and waste places. Native to Europe. 
Dandelion (Taraxacum officinale, Weber.).-A smooth, or, at first, pubescent perennial; head many-flowered borne on a slender, hollow scape; root-leaves pinnatifid or runcinate; involucre double, the outer of short scales, the inner long, linear, erect in a single row, but closing after flowering; fruit ripens close to ground, the hollow scape elongating, the whole involucre then becoming reflexed, thus permitting the wind to scatter the "seeds;" achenes ("seeds") oblong, long beaked, the beak two or three times as long as the remainder of the achene, bear-

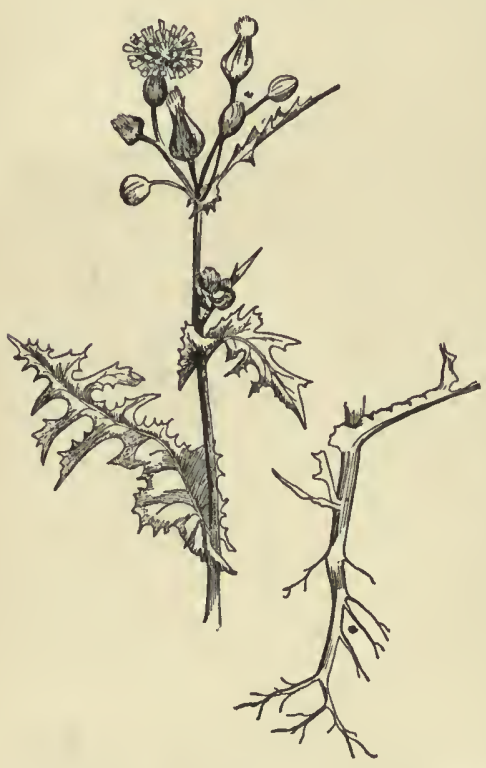
ing at the end long, soft, white capillary threads, the pappus. Probably native northward, but in the southern states naturalized from Europe. Common also in Asia; a cosmopolitan weed. Allied to the above species is a red seeded dandelion which is not uncommon in eastern Nortl America. It is very much like the common dandelion but has narrow "seeds" that are a bright red or red brown color; pappus a dirty white.

Field Sow Thistle (Sonchus arvensis, L.).- A

Fig. $160 a$. Common sow thistle glabrous perennial, pro(Sonchus oleraceus). (Ada Hay- ducing deep creeping
den.) rootstock, stem leafy, branched, basal leaves runcinate-pinnatifid, spiny toothed, clasping by a heart-shaped base; flowers yellow; achenes transversely wrinkled. Common in the eastern 
states and occasionally in Wisconsin, Illinois, Iowa and Utals. Abundant in Manitoba and Ontario.

Annual Sow Thistle (Sonchus oleraceus, L.)-Annual or perennial succulent herb with leafy stem, smooth and glaucus; corymbed or umbellate heads of yellow flowers; stem leaves dentate, runcinate-pinnatifid, terminal segments large and triangular; heads numerous; flowers pale yellow, occurring in summer and autumn. Common in fields and waste places throughout North America, especially far northward; also from Mexico to South America.

The Spiny-leaved Sow Thistle (Sonchus asper, (L.) Hill.) is nearly like common sow thistle; but has lower stem-leaves less divided and more spiny toothed.

Prickly Lettuce (Lactuca scariola, L.).- A tall, erect annual or winter annual, glaucus, green, two to six feet high, simple or branched tuca scariola). (C. M. King.) except on the lower part of the stem which has stiff bristles; leaves smooth except on the midrib where there are weak prickles; lanceolate to oblong in outline, with spiny toothed margin, occasionally wavy toothed, base arrow-shaped, clasping the stem; leaves becoming vertical by a twist (in shady places leaves not twisted) ; flowers in small heads on open panicles, each head bearing from four to fourteen yellow flowers; achenes flat, nerved, prolonged into a long, fili- 
form beak, the latter being paler in color than the seed; all parts of plant contain milky juice. Plant probably introduced into the United States as early as I863, and isolated specimens were reported here and there in the Mississippi Valley twenty-five years ago. In places it is almost beyond control. Common in Iowa in the northern and western parts of the state.

Wild Lettuce (Lactuca canadensis, L.).-This is a tall, leafy plant, glabrous or nearly so. Lower leaves are sinuate pinnatifid; the upper are entire. Flowers pale yellow. Achenes blackish.

Rushlike Lygodesmia (Lygodesmia juncea, (Pursh) D. Don.).-A tufted, smooth, frequently glaucus, perennial, a foot or more high, from a thick, woody root; copious milky juice; lower leaves rigid, linear-lanceolate, entire, upper leaves scalelike; heads erect with purple flowers; achenes narrow-ribbed; pappus light brown. Common on the plains from the Missouri River to western Montana, Northwest Territory and east to the St. Croix River in Wisconsin. Reported as troublesome in corn fields of northwestern Iowa, in Colorado and Montana.

Orange Hawkweed (Hieracium aurantiacum, L.).A low perennial, generally stoloniferous; leaves long, hirsute, hispid and glandular above; basal leaves hirsute; stem leaves one or two, sessile; heads clustered, peduncles glandular; involucral bracts linear, lanceolate, acuminate, hirsute; flowers deep orange or flame colored. Common in clover fields and meadows. Naturalized from Europe. Distributed from eastern Canada to Ohio and occasionally westward. 


\section{CHAPTER XV.}

\section{Partial Bibliography Consisting of Easily Accessible References, Arranged by Harriette S. Kellogg.}

1 Adams, G. E. Weeds: Their Eradication and Control. Bul. R. I. Agr. Exp. Sta., 133:51-61.

2 Anderlind, Leo. On Broom (Cytisus). See Sond. Forstl. naturw. Z., 1898. Heft 2. Abs. in Just's Bot. Jahresb. 1898. Abt. 2. 325.

3 Arthur, J. C. Delayed Germination of the Cocklebur. Proc. Soc. Prom. Agr. Sci., 16:70-79.

4 - Wild or Prickly Lettuce. Bul. Ind. Agr. Exp. Sta., 52:83-112.

5 Ball, C. R. The Purity and Vitality of Grass Seed. Bul. Ia. Agr. Exp. Sta., 54:164-180.

6 Seed Testing: Its Importance, History, and Some Results, with a Partial Bibliography. Rept. Ia. State College of Agr. and Mech. Arts, 17:161-175.

7 Beal, W. J. Grasses of North America, 1:100, 223, 224, 275. New York, 1896.

8 Methods of Killing Quack Grass. Proc. Soc. Prom. Agr. Sci., 14:27-28.

9 - Seeds of Michigan Weeds. Bul. Mich. Agr. Exp. Sta. 260:103-182.

10 - Some Unique Examples of Dispersion of Seeds and Fruits. Am. Nat., 32:859-866.

11 The Vitality of Seeds Buried in the Soil, A Series of Articles. Proc. Soc. Prom. Agr. Sci., 5:44-46; 6:14-15; 10:15-16; 15:283-284; 26:87-93.

12 Bessey, C. E. The Russian Thistle in Nebraska. Bul. Neb. Agr. Exp. Sta., $31: 67-77$.

13 The Weeds of Nebraska. Proc. Soc. Agr. Sci., 14:33-44.

14 Blankenship, J. W. The Loco and Other Poisonous Plants of Montana. Bul. Mont. Agr. Exp. Sta., 45:75-104.

15 Weeds of Montana. Bul. Mont. Agr. Exp. Sta., 30:7.

16 Bogue, E. E. Weeds of Oklahoma. Bul. Ok. Agr. Exp. Sta., 41:12.

$16 a$ An Annotated Catalogue of the Ferns and Flowering Plants of Oklahoma. Bul. Ok. Agr. Exp. Sta., 45:48.

17 Bolley, H. L. Canada Thistle: Means of Holding It in Control. Press Bul. N. D. Agr. Exp. Sta., 28:5.

18 The Destruction of Weeds in Cereal Crops by Means of Solutions of Chemicals Sprayed Upon the Foliage. Proc. Soc. Prom. Agr. Sci., 20:107-109.

19 Means of Eradicating Dandelions on Parks, Lawns, Roadsides and Meadows. Press Bul. N. D. Agr. Exp. Sta., 26:4.

20 On the Use of Chemical Sprays in Destroying Mustard, Kinghead and Other Weeds in Cereal Grain Fields, Press Bul. N. D. Agr. Exp. Sta., 27:4.

21 Quack Grass, How to Hold It in Check. Press Bul. N. D. Agr. Exp. Sta., $29: 2$.

22 - Weeds and Methods of Eradication. Seed Control by Means of Chemi cal Sprays. Bul. N. D. Agr. Exp. Sta., 80:513-574.

23 Bolley, H. L., and Waldron, L. R. A Preliminary List of the Spermatophyta, Seed-Bearing Plants of N. D. Bul. N. D. Agr. Exp. Sta., 46:593-675.

24 Brown, Edgar, and Crosby, Mamie. Imported Low Grade Clover and Alfalfa Seeds. Bul. Bur. P1. Ind. U. S. Dept. Agr., 111:17-30.

25 Brown, Edgar, and Hillman, F. H. Seed of Red Clover and Its Impurities. Far. Bul. U. S. Dept. Agr., 260:24.

26 Buckhout, W. A. Weeds in General: Two Newcomers into Pennsylvania. Bul. Penn. Agr. Exp. Sta., 58:8.

27 Burrill, T. J. Canada Thistles and Their Extermination. Bul. Ill. Agr. Exp. Sta., 12:379-387.

28 Clark, G. H. Weed Seeds Commonly Found in Timothy, Alsike, and Red Clover Seeds. Bul. Canada Dept. Agr., Seed Div. (N. S.), 16:13.

29 Clark, G. H., and Fletcher, James. Farm Weeds of Canada. With Illustrations by Norman Criddle, 97: pl. 56. Ottawa. 1906.

30 Claypole, E. W. On the Migration of Plants from Europe to America, with an Attempt to Explain Certain Phenomena Connected Therewith. Rept. Montreal Hort. Soc., 1877:70. 
31 Clinton, G. P. The Russian Thistle and Some Plants That Are Mistaken for It. Bul. Ill. Agr. Exp. Sta., 39:87-118.

$31 a$ Cox, H. R. The Eradication of Bindweed or Wild Morning Glory. Far. Bul. U. S. Dept. Agr., 368.

32 Coville, F. V. Noxious Weeds. Rept. U. S. Dept. Agr., 1890:388-392.

33 Craig, Moses. Some Oregon Weeds and How to Destroy Them. Bul. Ore. Agr. Exp. Sta., 19:21.

34 Crosby, J. O. Incursion of Weeds Into Our Gardens and Farms. Trans. Ia. Hort. Soc., 42:153-154.

35 Darlington, William. American Weeds and Useful Plants, Being a Second and Illustrated Edition of Agricultural Botany. 460, New York, 1859.

36 Dewey, L. H. Migration of Weeds. Yearbook U. S. Dept. Agr., 1896:263-285

37 Table of Two Hundred Weeds. Yearbook U. S. Dept. Agr., 1895:594-611.

38 - Twenty-five Most Harmful Weeds. Yearbook U. S. Dept. Agr., 1897: 641-645.

$39-$ Weeds and How to Kill Them. Far. Bul. U. S. Dept. Agr., 28:32.

$39 a$ Eaton, A. J., and Edson, H. A. A Practical Method of Killing Quack Grass. Bul. Vt. Ägr. Exp. Sta., 149:419.

40 Fernald, M. A. Some Recently Introduced Weeds. Trans. Mass. Hort. Soc., 1905:11-12.

41 Garman, H. On the Adulterants and Weed Seeds in Kentucky Samples of Blue Grass, Orchard Grass, Timothy, Red Clover and Alfalfa Seeds. Bul. Ky. Agr. Exp. Sta., 124:35.

42 Goff, E. S. Noxious Weeds. Bul. Wis. Agr. Exp. Sta., 39:38.

43 Noxious Weeds of Wisconsin. Bul. Wis. Agr. Exp. Sta., 76:52.

$44-$ The Russian Thistle. Bul. Wis. Agr. Exp. Sta., 37:13.

45 Gow, J. E. Preliminary List of the Flowering Plants of Adair Co., Iowa. Proc. Ia. Acad. Sci., 8:8.

46 Gray, Asa. Burs in the Borage Family. Am. Nat., 10:4.

47 New Manual of Botany. Seventh Edition, Illustrated. Edited by B. L. Robinson and M. L. Fernald. 926, New York, 1898.

48 Pertinacity and Predominance of Weeds. Am. Jour. Sci., 18:161-167.

49 Green, Wesley, Plants of Iowa: A Preliminary List of the Native and Introduced Plants of the State, Not Under Cultivation. Bul. Ia. Hort. Soc., 264. Des Moines, 1907.

50 Halsted, B. D. American and English Weeds Compared. Pl. World., 3:171-173.

$51 \longrightarrow$ Our Worst Weeds: A Scale of Points. Proc. Soc. Prom. Agr. Sci., 10:43-49.

52 The Weeds of New Jersey. Rept. N. J. Agr. Exp. Sta., 1890:370-453.

53 Harrison, F. C. Weeds of Ontario. Ont. Dept. Agr., 80. Toronto, 1900. Harrison and Lockhead. The Weeds of Ontario. Bul. Ont. Agr. Col., 128. See also a revised edition by Howitt.

54 Harvey, F. L. Three Troublesome Weeds. Bul. Me. Agr. Exp. Sta., 32:8.

55 Hays, W. M. The Russian Thistle or Russian Tumbleweed. Bul. Minn. Agr. Exp. Sta., 33:15.

56 Henderson, L. F. Twelve of Idaho's Worst Weeds. Bul. Ida. Agr. Exp. Sta., 14:91-136.

57 Hill, E. J. Notes on Migratory Plants. Bul. Torr. Bot. Club, 29:564-570.

58 Hillman, F. H. Clover Seeds and Their Impurities. Bul. Nev. Agr. Exp. Sta., $47: 90$.

59 Nevada Weeds. Bul. Nev. Agr. Exp. Sta., 21:15.; 22:11

60 Hitchcock, A. S. Clothier, G. L., and Norton, J. B. S. Various Reports on Kansas Weeds. Buls. Kan. Agr. Exp. Sta., 50:19-23; 52:87-101; 57:64; 66: $19-54 ; 76: 27 ; 80: 113-164$.

$60 a$ Howitt, J. E. The Perennial Sow Thistle and Other Weed Pests of 1908. Bul. Ont. Agr. Col., 168.

61 Jones, L. R. Impurities of Grass and Clover Seeds. Rept. Vt. Agr. Exp. Sta., 13:287-289.

62 - Killing Weeds with Chemicals. Rept. Vt. Agr. Exp. Sta., 12:182-188.

63 The Orange Hawkweed or Paint-Brush. Rept. Vt. Agr. Exp. Sta., $9: 115 ; 10: 251-254$.

64 Jones, L. R., and Edson, A. W. The Bird Vetch or Wild Pea. Rept. Vt. Agr. Exp. Sta., $14: 251-254$.

65 Jones, L. R., and Morse, W. J. The Shrubby Cinquefoil as a Weed. Rept. Vt. Agr. Exp. Sta., 16:173-190.

66 Jones, L. R., and Orton, W. A. Impurities of Vermont Clover Seed. Rept. Vt. Agr. Exp. Sta., 11:229-234.

67 Notes on Certain Threatening Weeds. Rept. Vt. Agr. Exp. Sta., 16: 169-173. 
68 - Notes on Vermont Weeds. Rept. Vt. Agr. Exp. Sta., 11:219-228.

$69-$ Orange Hawkweed or Paint-Brush. Bul. Vt. Agr. Exp. Sta., 56:15.

70 Kabsch, Wilhelm. Das Pflanzenleben der Erde. 642, Hannover, 1870.

$70 a$ Kalter, Grace M. The Weeds of the Miami Valley. Cont. Bot. Lab. Miami Univ., $4: 72$.

71 Kirk, T. W. Bathurst Bur. Leaflet for Farmers, New Zealand Dept. Agr., 2:2.

72 - Tarweed. Leaflet for Farmers. New Zealand Dept. Agr., 73:1.

73 Krafft, Guido. Pflanzenbaulehre. Pt. II. of Lehbr. d. L'dwirtschft. auf. wiss'schftl. u. prakt. Grundlage.

74 Lamson-Scribner, F., and Newman, C. L. Weeds on the Farm. Bul. Tenn. Agr. Exp. Sta., 1:29-52.

75 Lazenby, W. R. The Weedy Plants of Ohio. Proc. Soc. Prom. Agr. Sci?, $7: 42-47$.

76 MacMillan, Conway. Metaspermae of the Minnesota Valley. Geol. and Nat. Hist. Sur. Minn. Ser., 1:826.

77 Millspaugh, C. F. Descriptive List of Weeds of West Virginia. Bul. W. Va. Agr. Exp. Sta., 23:215-310.

78 Your Weeds and Your Neighbor's. Distribution of Our Weeds. Bad Points of Weeds. Weeds as Fodder for Stock. Chemical Weed Extermina. tor. Bul. W. Va. Agr. Exp. Sta., 22:177-212.

78 Moore, R. A., and Stone, A. L. The Eradication of Farm Weeds with Iron Sulphate. Bul. Wis. Agr. Exp. Sta., 179:17.

79 Munson, W. M. Dandelions and Hawkweeds. Bul. Me. Agr. Exp. Sta., 95:109-124.

80 Nelson, Aven. First Report of the Flora of Wyoming. Bul. Wyo. Agr. Exp. Sta., 28:47-218,

81 Squirrel-tail Grass, One of the Stock Pests of Wyoming. Bul. Wyo. Agr. Exp. Sta., 19:73-79.

82 The Worst Weeds of Wyoming. Bul. Wyo. Agr. Exp. Sta., 31:267-310.

$82 a$ Nelson, A. E. Some Common Weeds and Insects of Nebraska Corn Fields and Potato Patches. Bull. issued by Dept. Pub. Instr. and Dept. Far. Inst., Neb. $18: 32$.

$82 b$ Olive, E. W. The Killing of Mustard and Other Noxious Weeds in Grain Fields by the Use of Iron Sulphate. Bul. S. D. Agr. Exp. Sta., 112:485-498.

83 Pammel, L. H. The Canada Thistle and Dandelion. Bul. Ia. Agr. Exp. Sta., 61:143-153.

84 Ecology. 360, Carroll, Ia., 1903.

85 - Horse Nettle as a Troublesome Weed in Iowa. Bul. Ia. Agr. Exp. Sta., 42:131-136.

86 Noxious Weeds. Bul. Ia. Agr. Exp. Sta., 28:199-214.

87 Quack and Wheat Grasses. Bul. Ia. Agr. Exp. Sta., 83:397-416.

88 - Russian Thistle. Bul. Ia. Agr. Exp. Sta., 26:8; 38:24.

$89-$ Some Weeds of Iowa. Bul. Ia. Agr. Exp. Sta., 70:297-531.

90 - The Thistles of Iowa with Notes on a Few Other Species. Proc. Ia. Acad. Sci., $8: 26$.

91 Two Other Troublesome Weeds. (European Bindweed and Ground Burnut.) Bul. Ia. Agr. Exp. Sta., 42:137-139.

92 Weed Pests. Bul. Ia. Agr. Exp. Sta., 13:72-75.

93 Weeds of Corn Fields. Bul. Ia. Agr. Exp. Sta., 39:27-52.

94 Weeds of Southwestern Wisconsin, and Southeastern Minnesota. 20 , St. Paul, Minn., 1887.

94a Pammel, L. H., and King, C. M. Notes on Eradication of Weeds, with Experiments Made in 1907-1908. Bul. Ia. Agr. Exp. Sta., 105:265-300.

95 Parish, E. B. The Vegetation of Plymouth Three Hundred Years Ago. Rhodora, 3:17.

96 Rich, F. A., and Jones, L. R. A Poisonous Plant: The Common Horsetail. Bul. Vt. Agr. Exp. Sta., 95:187-192.

97 Roberts, H. F., and Freeman, G. F. Alfalfa Seed: Its Adulterants, Substitutes, and Impurities, and Their Detection. Bul. Kan. Agr. Exp. Sta., 133:53-111.

98 Commercial Seeds of Brome Grass, and of Kentucky Blue Grasses; Adulterants and Substitutes, and Their Detection. Bul. Kan. Agr. Exp. Sta., 141:71-141.

99 Saunders, D. A. Ferns and Flowering Plants Of South Dakota. Bul. S. D. Agr. Exp. Sta., 64:101-227.

100 Selby, A. D. A First Ohio Weed Manual. Bul. Ohio Agr. Exp. Sta., 83:249-400.

$101-$ Noxious Weeds Along Thoroughfares. Bul. Ohio Agr. Exp. Sta., 59:5.

$102-$ The Russian Thistle in Ohio and Weeds in General. Bul. Ohio Agr. Exp. Sta., 55:53-59. 
103 A Second Ohio Weed Manual, Bul. Ohio Agr. Exp. Sta., 175:291-383.

104 Stewart, F. C. The Impurities of Clover Seed. Bul. Ia. Agr. Exp. Sta., 21: 805-814.

105 Stewart, F. C., and French, G. T. Dodder in Alfalfa Seed. Cir. N. Y. Agr. Exp. Sta., 8:4. (N. S.)

106 Stewart, F. C., French, G. T., and Wilson, J. K. Troubles of Alfalfa in New York. Bul. N. Y. Agr. Exp. Sta., 305:333-416.

106a Stone, A. L. The Control of Quack Grass and Canada Thistles. Cir. Inf. Univ. Wis. Agr. Exp. Sta., 19:13.

107 Thornber, J. J. Some Practical Suggestions Concerning Seed Testing. Bul. Ariz. Agr. Exp. Sta., 55:99-102.

108 Thorn, C. E. A Pestiferous Weed (Wild Lettuce). Bul. Ohio Agr. Exp. Sta., $44: 141-146$.

109 Toumey, J. W. Something About Weeds. Bul. Ariz. Agr. Exp. Sta., 22:32.

110 Vasey, George M. Weeds of Agriculture. Rept. U. S. Dept. Agr., 1886:84-93.

$110 a$ von Degen, A. Ueber Kleeseide Jahresb. d. Ver. f. angew. Bot., 1906:289-317. (Contains many references to dodder as an impurity in clover seed.)

111 Waldron, C. B. Troublesome Members of the Mustard Family. Bul. N. D. Agr. Exp. Sta., 6:19.

112 Weed Studies. Bul. N. D. Agr. Exp. Sta., 6:19.

113 Weed, C. M. Plant Travelers. Nat. Study Leaflet, N. H. Agr. Exp. Sta., $3: 27-32$.

$114-$ Seed Travelers. 53, Boston, 1901.

115 Williams, T. A. Fungi Damaging Both Úseful Plants and Weeds. Bul. S. D. Agr. Exp. Sta., 29:51-52.

116 Some Plants Injurious to Stock. Bul. S. D. Agr. Exp. Sta., 33:21-44.

117 Wilson, A. D. Some Common Weeds and Their Eradication. Bul. Minn. Agr. Exp. Sta., 95:195-237.

118 Wilson, James. Russian Thistle. Bul. Ia. Agr. Exp. Sta., 26:7.

119 Wooton, E. C. New Mexico Weeds. Bul. N. M. Agr. Exp. Sta., 13:36.

120 The Russian Thistle. Bul. N. M. Agr. Exp. Sta., 16:20.

\section{Partially Classified List with Reference to Publications Listed Previously.}

Name of Weed

Number in List

Bathurst Bur......................................... 71

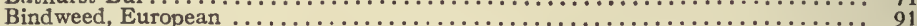

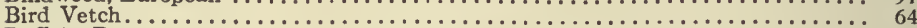

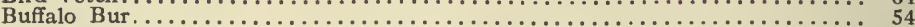

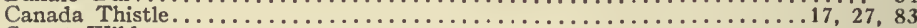

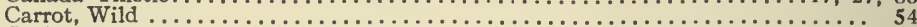

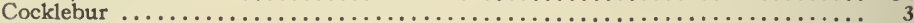

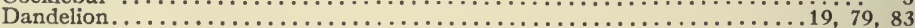

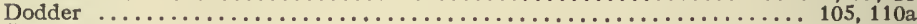

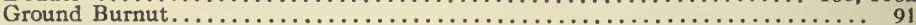

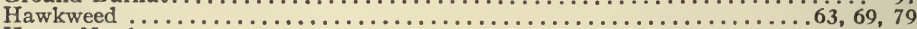

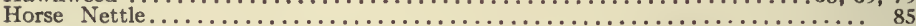

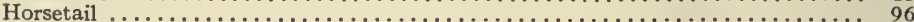

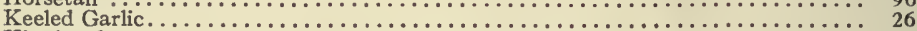

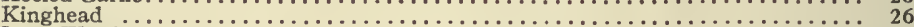

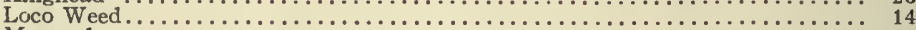

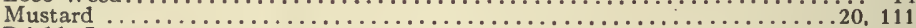

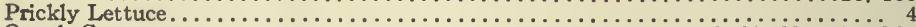

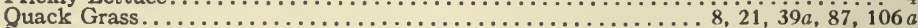

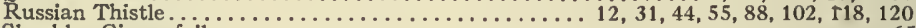

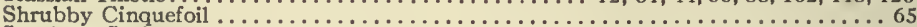

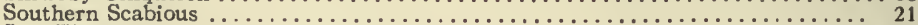

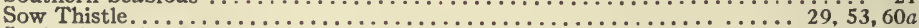

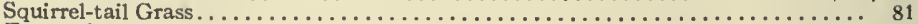

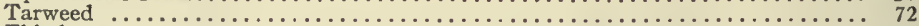

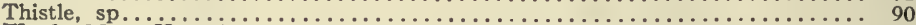

Weeds, Many Varieties, $13,13,16,22,26,29,32,33,35,37,38,39,42,43,51,52,53$, $59,60,68,70 a, 75,77,82,82 a, 89,94,100,103,110,118$.

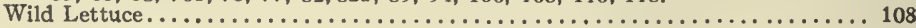




\section{INDEX}

Page

Abronia ........................ 172

Absinth ................. 245

Abutilon

avicennae ............. 74

Theophrasti $\ldots \ldots 27,84,200$, f. 200

Legislation ........... 43

Acacia, Germination.......... 42

Acalypha virginica.........74, 194

Accessory bud................ 117

Acclimatization of plants ..... 83.84 Acer

macrophyllum ............. 199

nigrum ................. 199

saccharum ................ 199

Achene................... 132

Achenium.............132, f. 134

Achillea millefolium ........75, 243

Acnida tuberculata..........27, 171

Aconite ................. f. 128

Acorn ..................15, 133

Aderhold ................ 95

Adnate filament............. 129

Adnation ................. 127

Adventitious bud............... 117

African weeds............. 81

Agaric, Fly ................. 64

Aggregate fruit............ 132

Agropyron repens. . 73, $153-155$, f. 154 Legislation .............. 43

A grostemma Githago $69,81,170$, f. 176

Agrostis alba.............73, 149

Alfalfa ................ 28, 30 Impurities ............35-36, t. 36

Alfilaria, Musky.............. 192 Allium

canadense ............72, 159

ricoccum .................. 72

vineale $\ldots \ldots \ldots \ldots \ldots \ldots \ldots 1,72,159$

Distribution............... f. 79

Alopecurus geniculains........70, 148

Alsike ...............29,30,33

Impurities $\ldots \ldots \ldots \ldots \ldots \ldots 35, f .35$

AM ARANTHÄ $\dot{\mathrm{E}} \dot{\mathrm{E}} \mathrm{E} \ldots \ldots \ldots 136,170$

Amaranth ................. 80 Spiny ............. 80,171

Amaranthus

albus ............................. 84

blitoides...........171,f. 172

retroflexus. ........28,73,84, 170

Vitality ............ 37

Germination ............ 42

spinosus .........73, 80, 84,171

A mbrosia artemisiaefolia

$33,73,234$, f. 235

Vitality ............ 37 psilostachya.........59, 73, 234-235 trifida ........73,80, 234, f. 237

Germination .......... 42
American Association of Official Seed Analysts .......43, 49 American Seed Trade Association 43 Ammonium sulphate.......... 95

A mpelopsis arborea........... 69

Amphitropous ovule.......... 132

Amsinckia intermedia........... 216

ANACARDIACEAE ......... 1336, 198

Anatropous ............... 132

Andropogon

Halapense .............. 71

sorghum ................. 69

virginicus .............. 55

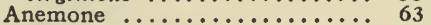

Anemopsis californica ......... 160

Angiosperm ................ 129

Animals

As seed carriers.......15, 18, 41-42

Germination of seeds fed to... 41

Annuals ................ 7

Spear grass ........... 61

Anthemis

arvensis ........... 69, 243-244

Cotula ..............33,70,243

Vitality .............. 38

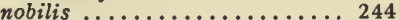

Anther .................. 129

Extrorse ......................... 129

Introrse ................ 129

Anthony, $\dot{R}$. I. . . . . . . . . . . . . 102

Apetalous flower................ 126

A pium graveolens............. 69

APOCYNACEAE...... 137, 208-209 A pocynum

androsaemifolium . . . . . . 69, 208 cannabinum ........ 69, 208-209

Apple .................. 133 Purple thorn............ 222-223

Tree ................... 5

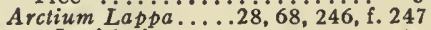

Legislation ........... 43

Argemone

intermedia ............... 59

mexicana ............... $60,73,84$

platyceras .............. 73

Aristida

dichotoma ..........59, 146-147

fasciculata ....................... 147

oligantha ............. 73, 147

Arizona, Native pasturage...... 51

Arrow-head ............... f. 18 Artemisia

absinthium .............. 245

biennis ........ 75,245, f. 245

Ludoviciana ...........71, 75, 245

tridentata ............. 245

vulgaris .......................... 245 
Arthur, J. C. .......... 84, 110

Artichoke ..........52,58,62, 68

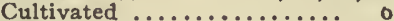
Wild

Ascending ovule.................... 130

ASCLEPIADACEAE .. 136, 209-210 Asclepias

incarnata .............. 54

speciosa .................... 7 i, 209

syriaca .......54, 71, 210, f. 210

Germination ........... 39

tuberosa 209

verlicillata ............ 209-210

Ash ..................120, 132

Asparagus officinalis ..........668

A sier .................. 59,68

ericoides ..............231-232

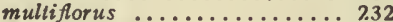

New England ............ 232

novae-angliae ............... 232

salicifolius ...........58, 232

Tradescanti ................ 58

White ..............231-232

White, small-flowered....... 232

Willow-leaved ........... 232

Asiragalus ............... 71

canadensis .................... 73

mollissimus................. 71

Atriplex ...................... 60

hastata ............... 72

patula ................ 169, f. 171

Australia, weeds of ........... 78

Avena

fatua $\ldots \ldots \ldots \ldots \ldots .57,72,149.150$

Germination .......... 42

A vens, White.............68, 186

Awned

Barley .................. 68

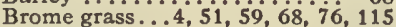

Axile placenta.............. 130

Bachelor's button. . . .....68, 250-251

Ballast, Weeds in........... 81

Balloon Vine........... 14, 68, 199

Barbarea vulgaris...........669, 184

Barberry............... 125, f. 127

Barley .................. Awned $\ldots \ldots \ldots \ldots \ldots \ldots \ldots \ldots 60 . \ldots 6$ Little ............155, f. 155 Mountain ............... 68 Small ................. 68 Squirrel ..................... 68 Wild $\ldots \ldots \ldots 4,57,59,64,78,115$

Eradication..........111-112 Barnyard grass

$$
16,28,30,33,56,62,142
$$

Basswood, Seed of ........... 14

Beal, W. J................. 37

Bean ................. 129

Castor-oil .............. f. 131

Lima..................... 64

Seed ........... f34, i3i, f. 132

Wild .............58,68, 191

Bearded Darnel................ 153

Beard Grass .............. 68

Beck ........................ 85

Becquerel ................ 36

Bedstraw ................ 228

Bee plant, Rocky Mountain

$68,115,130,184$, f. 185

Beet ...............80, 167

Cultivated ..................... 115

Sugar $\ldots \ldots \ldots \ldots \ldots \ldots \ldots \ldots 167$

Beggar's Lice.................... 216

Beggar-ticks

$13,15,62,68,239-240$, f. 241 , f. 242

Bell-shaped corolla........... 128

Bermuda grass............... 68

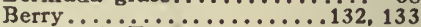

Bessey, C. E................ 16,90

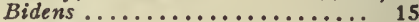

aristosa .................. 74,240

discoidea ................... 11

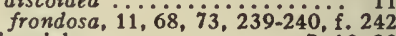

Biennials .............7, 10, 90

Wormwood .............. 16, 75

Bindweed ................... 166

Eradication ............. 95

Black.........24, 30,68, f. 116

European ............54, 58, 212

Hedge ........24, 211-212, f. 212

Birch ................. f. 124

Birds, seed-scattering agents

f. 14 , f. 19, f. 20

Bitterweed, Prairie.......... 115

Black

Bindweed.........24, 30, 68, 116

Cherry, wild .............. 64

Henbane ............ $5,63,71$

Knapweed ..............250

Locust ................... 63

Medick...42, $59,7 i, i 15, i 90$, f. 190

Mustard 24, 30, 46, 72, 76, 182, f. 182

Nightshade ..........13, 18, 72

Raspberry .............. 187

Blackberry, wild............. 26

Bladder

Campion .............. 176

Ketmia ......... 28,202 , f. 202

Bloodroot ................ 63

Blue

Grass .........15, 28, 36, 62, 93

Canadian $\ldots \ldots \ldots \ldots \ldots \ldots \ldots \ldots, 35$

English ................ 152

Kentucky ..........35, f. 36

Larkspur .............. 71

Lettuce .................... 115

Morning Giory................ 71

Pearl Grass............... 36

Thistle .................. 67

Vervain .......33, $54,74,88,217$

Vitriol (see copper sulphate)

Blue-bottle.............. 250-251

Blueweed ............58, 68, 217

Boerhaavia .................. 59

erecta ........... I73

Bolley, $\dot{H} . \dot{L} .2,4,6,16,67,95$,

$96,97,99,100,101$

Boneset . . . . . . . . 52, 58-59, 231

Bootjack ...............10, 18, 58

Borage Family ............19, 215

BORAGINACEA E ..... 137, 215-217

Bordeaux mixture..........94, 95

Bouncing Bet.....24, 60, 63, 68, 176 
Page

Bracted Plantain

28. 30. 32. 33. 55. 115, 227, f. 228

Germination .......... 42

Legislation . .......... 46

vervain. $\ldots \ldots \ldots \ldots \ldots .74$

Bracts expanded........... 14

Brake, Common

Brassica

57. 63. 68.137 . f. 138

arvensi

Distribution $\ldots \ldots \ldots \ldots \ldots$ f. 77

Legislation ............. 43

nigra.........28, 33, 182, f. 182

oleracea ................ 179

Brazil, Weeds of ........... 81

Brendel ................ 85

Briar

Sand................. 83

Sensitive.............. 68

Bristly foxtail.............70, 143

Britton. N. L................ 83

Brome grass ............56, 115

Annual................. 62

Awned......4, $51,59,68,76,115$

Downy................. 153

Hairy ................68, 115

Quaking...........57,68,76

Bromus

brizaeformis ...........57,68

hordeaceus............ 68, 153

racemosus ............... 69

secalinus ............. 58, 69,152

Germination .......... 42

Vitality ................ 37

iectorum ..........56-57, $6 \dot{6}, 153$

Broom-rape.............. 225

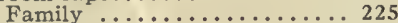

Broom Sedge.............. 55,67

Brown Krapweed..........250

Buchenau ............... 82

Buckhorn $10,11,13,24,32,67$, $68,86,115,227$, f. 227

Germination ........... 42

Buckwheat...........17, 63, 131

Family................ 162-167

Seed................... 134

Wild.................... 166

Germination .......... 38

Buds.................... 117

Accessory ............... 117

Adventitious ............. 117

Fleshy ................ 117

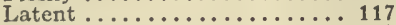

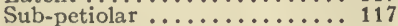

Terminal .......................... 117

Buffalo Bur $16,54,58,59,60,62$, $67,68,77,78,115$

Bulb-bearing Hemlock ........ 63

Bulblets

Bull thistle $7,16,23,26,28,30$, $52,62,67,74,77,79,83$, $86,90,115,246-247$, f. 248

Bunch-flower ........... 63

Bur clover...59, $99,7 \ddot{8}, \dot{80}, \ddot{11} \dot{15}, 190$ Germination ........... 42

Burdock $7,12,13,18$, f. $21,24,26$, $28,30,58,67,68,90,115,246$
Burdock Eradication........96, 9 Legislation ................ 43

Bur.nut. Ground .......... 193, f. 193

Burweed. vellow ............ 216

Bush. Morning Gilory............ 211

Bushy Knotweed............. 165

Butter and Eggs........24, 68, 224

Buttercup ..............58, 132 Tall .... ............ 178

Butterfiv.weed ............. 209

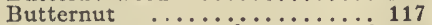

Butter Print ........ 131,200, f. 200 Eradication ............ 112

Buttonweed ...........67, 68, 228

Cabbage ... .......... 115, 179 Club-root of ............ 4

Calabacilla ........................ 69

California weeds...........59, 68-75

Caltrop..............193, f. 193

Family .............. 192-193

Calycanthus ............. 63

Camas

Death.. .............. 159

Swamp................... 64

Camelina sativa..........28, 70, 181

Campanula

Family ............... 229

persicifolia

Germination ........... 40

rapunculoides ............... 229

rolundifolia ............... 229

CAMPANULACEAE ....... 137, 229

Campanulate corolla.......... 128

Campbell, J. R..............29, 67

Campion, Bladder...................... 176

Campylotropous ovule........ 131 Canada

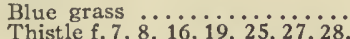

35

$30,52,57,58,60,65,67$,

$74,78,79,83,115,248-250$, f. 249

Distribution........... f. 79

Eradication ...95, $96,98,99,103$

Legislation ............ 43

Seed .............. 7

Canadian Goldenrod............ 11

Lettuce ............... 10,13

Canary Grass................. 145

Candy Grass.............. 151-152

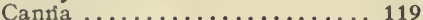

Cannabis sativa............81, 161

Caper .................... 63 Family ................ 184-185

CAPPARIDACEA E ... . 136, 184-185

CAPRIFOLIACEAE... . 137, 228-229

Capsella Bursa-pastoris... 73, 81, 181 Vitality ............... 37

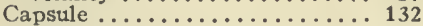

Caraway ..............59, 68, 206

Carbolic acid ......95, 97-98, 108, 109

Cardiospermum Halicacabum

$68,84,199$, f. 199

Carnation ............... 174

Carolina Crane's-bill ......... 59

Larkspur ................. 71

Carpel............129-130, f. 131 
Carrot.....7, 10, 54, 80, 85, 116. 125 Cultivated...........115. 207 Family................. 205-207 Small ................... 207 Wild f. $21,31,33,34,58,59,67$, $68,100,207$, f. 208

Eradication ........... 100 Carum carui.............68, 206 CARYOPHYLLÄEAE $136,173-176$ Caryopsis ............... 133 Cashew Family................ 198 Cassia Chamaecrista..... . 28, 72, 188 marilandica........... 73, 188 nictilans ................. 188 occidentalis..........73,80, 188 Tora ................... 188 Castor-oil Bean Seed........... 131

Catchfly.............29, 30,68 Evening.........86, 175, f. 175 Night-flowering.....23, 33, 58, 176 Sleepy ................ 175

Cates, J. S.................. 106

Catkin.............. 124, 125

Catnip..............28, 30, 219

Cat's ear..............61, 62 Long-rooted...........251,f. 251

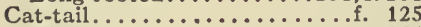

Caulicle .................. 134

Cedar ...................... 129

Red $\ldots \ldots \ldots \ldots \ldots$ f. 14

Celandine.............58, 179

Celery.................54, 69,80

Cenchrus tribuloides........73, 143-144 Centaurea

Calcilrapa .............. 250

Cyanus................... 81,250

Jacea . . . . . . . . . . . 250 nigra ................. 250 solstitialis ............... 250

Distribution .............. 77,79

Century Plant............. 118

Cerastium

nutans ............... 174

viscosum.................... 174

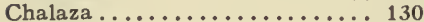

Chamomile.............. 69

Corn.................243-244

Garden ................ 244

Wild ....................... 69

Charlock............76,81,94

English ............... 181-182

Cheat..................... 152

Cheeses........58, 62, 69, 1 is, 201

Chelidonium majus............ 172

CHENOPODIACEAE .. 136, $167-179$

Chenopodium

album .......28, 33, 70, 169, f. 169

Germination .......... 42

ambrosioides .......... 7i, 80,168

Fremontii. ...........59,70, 168

hybridum ............. 70

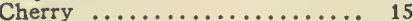

Choke $\ldots \ldots \ldots \ldots \ldots \ldots \ldots \ldots \ldots .6 . \ldots \ldots$

Wild Black............... 64

Chess.......f. 23, 58, 69, 115, 152 Germination ........... 42

Soft................... 153
Page

Chestnut, Horse. . 64, 117, f. 119, 120

Chicken Corn.............58,69

Chickweed $7,24,58,62,69,132$,

i74-175, f. 174

Eradication ........... 101

Mouse ................. 174

Mouse-ear ............... 174

Chicory $\ldots . .5,16,33,58,69,82,86,251$

Chilean Dodder............ 213

Chili, Weeds of ............... 81

China, Weeds of ............ 81

Chinquapin, Water............ 15

Chondrilla ............................... 69

juncea ............... 69, 251

Choke Cherry.............. 63

Chrysanthemum Leucanthemum

$52,72,244$, f. 244

Cichorium Intybus.......33,69, 251

\section{Cicuta}

bulbifera............206, f. 207

maculata ....54, 69, 205-206, f. 206

vagans ................ 55

Ciliate, Elder ............. 70

Cinquefoil................ 30

Showy ................ 186

Silvery

Germination ......... 40

Cirsium

arvense... 28, 74, 248-250, f. 249

Iowa law ............ 43

canescens...........59, 74, 247

discolor........10, 28, 30, 247-248

iowense ..................52

lanceolalum

$28,33,52,74,246-247$, f. 248

Germination ............ 42

Nelsoni................ 74

scariosum .................. 57,74

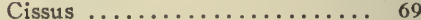

Clapper, Lyle ................ 12

Clarkia elegans.............. 204

Cleistogamous flowers......... 15

Cleome integrifolia ............. 68 serrulata........... 164-185, f. 185

Clotbur ................ 236

Clover ...6i, $93,120,125$, f. 126,128 Alsike ............29, 30, 33 Impurities in sccd ....... 35, f. 35 Bur .....59, 69, 78, 80, 115, 190 Germination .......... 42

Crimson .............. 63 Dodder $15,28,36,69,11 \dot{1}, 213$, f. 213

Hop ................ 69

Hop, low .................. 189

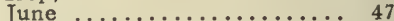

Pea-vine ................. 47

Red f. $25,29,31$, f. 35

Germination ......... 42

Impurities in seed....33-34, f. 34

Medium ............ 47

Small ............... 47

Sapling. . . . . . . . . . . . 47

Sprays injurious to....... 101,102

Sweet, White 5, 6, 24, 25, 26, 28,

$31,55,56,58,59,74,115,189$ As a forage plant ........ 55 
Clover, Sweet White, Germination 24 Honey plant........... 55 Soil renovator.......... 55 Sweet, Yellow....59, 74, 189, f. 189 Clover Meadows

Weeds in ...19-23, 32, 67, 85-86

Clover Seed, Impurities .......27-29

Club-root of cabbage.......... 4

Cockle............5, 23, 58, 67 Corn .......23,95, 134, 176, f. 176 Eradication .......... 95

Cocklebur $10,13,18,18.20,25,58$, $59,62,63,65,66,67,69$, $88,115,235-236$, f. 238

Eradication........95, 110-111

Germination ...........39, 42, 87

Legislation ............ 43

Spiny $\ldots \ldots \ldots \ldots \ldots \ldots \ldots .6 . \ldots$

Coffee $\ldots \ldots \ldots \ldots \ldots \ldots \ldots \ldots$. 5

Coffee Tree, Kentucky......... 64

Colorado, Weeds in.......... 68-75

Comfrey, Corn............... 69

Commissioner

Park .................. 61

Weed $. . . \ldots \ldots \ldots \ldots \ldots \ldots, 61$

Compass plant.............. 78

Complete flower............ 125

COMPOSITAE .......137, 229-254

Compost, Effect on germination 41-42

Coneflower ............69, 237

Conical root................ 116

Conium .................. 59 maculatum ............70, 205

Conringia orientalis.......... 182

CONVOLVULACEAE 137, 210-214

Convolvulus

arvensis .........54, 58, 71, 212

Family ............... 210-214

sepium.....54, $71,211-212$, f. 212

Copper sulphate......90, 94, 95, 96

Coralberry ............228-229

Corispermum hyssopifolium.... 80

Corn ...........126, 129, 139, 189

Chamomile ...........243-244

Cockle 23, 57, 63, 134, 176, f. 176 Eradication .......... 95

Comfrey ............... 69

Indian ........... 1i, 118, f. 134 Germination .............42 Poppy, smooth-pointed....... 179

Cornfield ............... $1,2,58$ Weeds in ............6.67, 92-93

Corolla .................127-128 Bell-shaped................ 128

Campanulate .............. 128

Funnel-form .............. 128

Irregular .......125, f. 127, f. 128

Labiate ................. 128

Ligulate ............... 128

Papilionaceous ............... 128

Salver-form ............ 127

Strap-shaped ............... 128

Tubular ................. 128

Two-lipped ................ 128

Wheel-shaped .........127, f. 127

Corrosive sublimate........95, 99

Corymb .................. 124
Cosmopolitan Weeds......... 81

Cotton, root-rot of .......... 5

Cotton plant ............... 13i, 200

Couch grass........... 153-155, ל́. 154

Cowbane

$4,11,54,63,69,115,205-206$

Western ............ 55 Cowherb $5,23,28,30,537,58,69$,

115,176, f. 177

Cox, Mr............... 113

Crab Grass $9,26,28,30,42,56$, $57,58,59,69$

Eradication ..........101, 103

Germination .............4 42

Smooth

$31,33,62,69,139-140$, f. 140

Sprouting ............. 142

Cranesbill, Carolina............. 59

Creeping Charley ............ 24

Crowfoot ................. 69

Creeping mechanism, in seedscattering ........15, 18-19

Cremocarp ............... 133

Cress

Water ............... 69

Winter $\ldots \ldots \ldots \ldots \ldots \ldots \ldots \ldots, 184$

Crested Dog's-tail............. 36

Crimson Clover.............. 63

Crocker, Wm................. 110

Crotalaria sagittalis .........73, 188

Croton

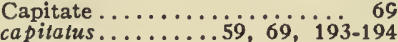

Distribution ........... f. 77

monanthogynus .............. 59

Texas ................. 69

texensis ................... 69

Crowding, Effect of ............ 3

Crowfoot ..............6. f. 179

Creeping .............. 69

Cursed ......63, $69,177, i .179$

Early................. 178

Family $\ldots \ldots \ldots \ldots \ldots \ldots \ldots \ldots \ldots 177^{178}$

Grass ................ f. 150

Small-flowered............ 177-178

CRUCIFERAE .....136, 179-184

Cruel Plant................. 197

Crusaders, Weeds carried by.... 81

Cuckoo Flower............... 175

Cucumber

Squirting $\ldots \ldots \ldots \ldots \ldots \ldots, 15$

Star. ................ 119

Cultivation

Means of seed-scattering ..... 19

Value of ......87, 106, 108, 109

Curled Dock....42, 43, 115, 162-163

Curly Maple............... 199

Currant ..................... 124

Indian $\ldots \ldots \ldots \ldots \ldots \ldots 71,228$

Cursed Crowfoot..63, 69, i77, f. 179

Cuscula ................. 212 arvensis

$28,30,33,69,213-214$, f. 214

decora ................ 214

Epilinum ............... 214 Epithymum....28, 69, 213, f. 213 racemosa v. chiliana........ 213 
Cuscuta, trifolii

Darlington, $W$ m............... 85

Darnel ..............64, 69

Bearded .............. 153

Common .............. 153

Poison .................. 153

Date Seed............... f. 134

Datura

Metel ...........71, 74, 222

Stramonium ............28, 71,80

Tatula.......71, 222-223, f, 223

Wright's .........6.63, 64, 222

Daturin ............... 5

Daucus Carota............33, 55, 68

Death Camas............... 159

De Candolle, A............. 36

Dehiscent fruit............ 132

Delphinium

azureum .............. 178

carolinianum ............... 71

Geyeri .................. 71,178

tricorne ...............71, 178

Determinate infiorescence... 124, 125

Dewberry .......................... 187

Dewey, L. H...........60, $61,81,83$ Dianthus

barbatus ............... 174

Caryophyllus .................... 174

DICOTYLEDONEAE ....... 135

Dicotyledonous............ 134

Diffuse Dropseed............. 70

Digitalis ................. 5 pur purea......... $70,223,224-225$

Digitaria

humifusa . . . . 33, 69, 139-141, f. 140 sanguinalis $28,33,56,69,139,141$ Germination ........... 42

Diodia teres............... 68, 228 Dioecious flowers............. 126 DIPSACEAE $\ldots \ldots \ldots \ldots \ldots \ldots 137$ Dipsacus Fullonum ............ 74 Dock .......12, 17, $1828,62,86$ Germination $\ldots \ldots \ldots \ldots 41$ Bitter $\ldots .24,28,30,33,53,67,69$ Curled ............115, 162-163 Germination ............. 42 Legislation .............43,46

Dock, Pale ... . . . . . . . . . . . 163

Patience ................69, 163

Peach-leaved............ 12, 163

Smooth ........53, 67, 69, 115 Legislation ...........43,46

Sour ................. f. 163 Eradication ........12,66, 100 Germination ........... 41

Velvet .................. 224

White....................... 163

Dodder.............27, 212-214

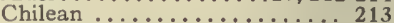

Clover $15,28,56,69,116,213$, f. 213 Field $33,56,69,213-214$, f. 214

Flax................ 70, 214

Dogbane...................... 115

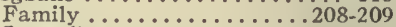

Spreading ..........6.64, 69, 208

Dog Fennel 13, 24, 62, 70, 115, 243

Dog's-tail, Crested........... 36

Dooryard Weed...........164, f. 165

Knotweed . . . . . . 62, 71, 115

Eradication .............. 100

Dormant period..........39, 40,110

Dorsal suture................ 129

Downy Brome Grass............. 153

Driftwood, as seed-carrier....... 15

Dropseed Grass

Eradication ........... 110

Diffuse .................... 70

Mexican............. . . $70,147-148$

Spiked ............... 70

Drupe ................... 133

Dry fruit................. 132

Duckweed .................. 15

Dusserre .................. 95

Dust spray as herbicide........ 100 Dyssodia.

chrysanthemoides ......... 70

papposa ...............242-243

Early Crowioot.............. 178

Eaton, Dr. A.............. 85, 107

Echinochloa crus-galli ....28, 56, 142

Echium vulgare............ 68, 217

Eclipta alba .............70, 237

Edson, A. W........95, 97, 99, 107

Eichornia crassipes........... 84

Elder.................... 70

Ciliate ............ 70

Marsh $51,59,62,67,70,83$,

115,233, f. 234

Marsh, small-flowered .... 233-234

Meadow ............... 70

Elderberry $\ldots \ldots \ldots \ldots \ldots \ldots \ldots \ldots .64$

Eleusine indica 59 , $690,150-151$, f. 150

Ellisia nyclelea............. 215

Elodea canadensis.............. 84

Embryo .................. 133

Sac ....................... 130

Endogenous stem........... 117

Endosperm ............... 133

English

Charlock.............. 181-182

Rye Grass Legislation . . . . . . . 46, 47

Epidermis ................. 117

Epigaeous ................... 134

Epigynous flowers............ 127 
Epilobium angustifolium..70, 77, 204 Epiphytes ................ 116 EQUISETACEAE . . ...135, 138-139 Equisetum ............... 138 arvense ..........57, 71, 138

Eradication of weeds .......87-113 Annuals . ......87,89-90, 94, 97 Biennials ................. 90 Perennials......887, 90-91, 94, 97 Eragrostis

major................ 74 megastachya ..............151-152 pilosa .................. 151 Purshii .................. 73 Erechtiles hieracifolia

$70,245-246$, f. 246 Vitality ............... 37

Erect Knotweed................. 73

Erect ovule.............. 130 Erigeron annuus.......52, 70, 232, f. 232 canadensis ...71, 81, 82, 233, f. 233 divaricatus ............ 233 ramosus........52, f. $53,70,232$ Erodium cicutarium ......19, 57, 192, f. 192 moschalum .............74, 192

Erysimum asperum ................. 184

cheiranthoides ............ 183

Eupatorium ................... 52,58 ageratoides ............230-231 coelestinum ..................231 perfoliatum ............... 231 purpureum ................. 231 serotinum .............74, 230

Euphorbia ................. 194-198 Cyparissias ............197-198 dentata ................ 197 helerophyilia .............. 197 maculata .........74, 196, f. 195 vitality $\ldots \ldots \ldots \ldots \ldots \ldots, 37$ nutans .............. 33 Preslii.....10, 28, 74, f. 194, 195 EUPHORBIACEAE

$135,136,193-198$

European

Bindweed ...........54,58, 212

Heliotrope $\ldots \ldots \ldots \ldots \ldots \ldots .215$

Morning Glory........... 71

Weeds ........78, $80,81,83,84$

Eustoma Russellianum........ 71

Evening

Catchfly..........86, 175,f. 175

Primrose .......13, 73, 205, f. 205

Ewart, A. J................ 37

Exogenous stem ............ 117

Explosive เruits ....... 15, f. 21, f. 22

Extermination of weeds. See Eradication

Extrorse anther............. 129

Fall Dandelion........... 58

False

Flax ...........28, 30, 70, 181 Eradication ............ 95

Hellebore ..............64, 159 Mallow................200 201
False, Ragweed............. 59 Red Top.................28, 30

Fawcett, H. S............ 38, 39 Fennel, Dog 13, 24, 62, 70, 115, 243

Fern Family............... 137

Fescue Grass.................. 35

Festuca elatior pratensis

Legislation ..........46, 47 pratensis ............... 36

Legislation............... 48

Fetid marigold...62, $70,115,242-243$ Field

Dodder 33, 56, 69, 213-214, f. 214

Garlic ................ 72

Mustard ................... 28

Pennycress .............. 40

Sow Thistle ............252-253

Thistle .................. 10,13

Figwort Family..............223-225

Filament ................. 129

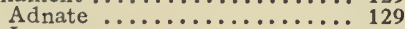

Innate ................. 129

Versatile ................... 129

Finger Grass . .............. 139, 141

Fireweed 77, 204, 216, 245-246, f. 246 Mexican ........23,59,70, 115

Purple ................ 70

Yellow ................... 70

Five-finger...........24, $28,33.58$ Common ................. 185

Flag, Large Blue ............. 64

Flax .................... 64

Dodder ...............70, 214

False ...........28, 30, 70, 181 Eradication ........... 95 Legislation ................. 48

Flax Field ............... 4

Fleabane ............... 232, f. $^{232}$

Daisy ............... 70

Daisy annual............... 70

Fleshy Buds.............. 117

Fruit $\ldots \ldots \ldots \ldots \ldots \ldots \ldots \ldots \ldots \ldots \ldots \ldots$

Fletcher $. \ldots \ldots \ldots \ldots \ldots \ldots \ldots \ldots, 95$

Flower

Apetalous ............... 126

Cleistogamous .............. 15

Complete ............... 125

Diandrous $. . . \ldots \ldots \ldots \ldots \ldots . .129$

Dioecious ............... 126

Disk .................. 128

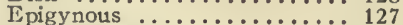

Gamopetalous .............. 126

Hermaphrodite ............. 125

Hypogynous $\ldots \ldots \ldots \ldots \ldots \ldots 127$

Inferior ................... 127

Irregular.......125, f, 127 , f. 128

Monandrous ............. 129

Monoecious .............. 125

Morphology of ...........124-129

Papilionaceous .........f. 127, 128

Perfect ................. 125

Perigynous .............. 127

Polygamous ................ 126

Polypetalous ............ 126

Ray .................. 128

Regular .............. 125, f. 128 
Flower, Superior . . . . . . . . . 127

Fly Agaric.................. 64

Follicie .............f. 131, 132

Formaldehyde . . . . . . . . .95, 99

Foulkes .................. 95

Four-o'clock

Family ............... 172-173

Wild .......70, 172-173, f. 173

Foxglove ..........5, 70, 78, 223

Purple .............64, 224-225

Foxtail $10,16, f .17,24,26,30$,

$51,56,57$

Eradication.....96, 98, 101, 111

Germination ...........4 42

Bristly .............. 70, 143

Downy Mildew of ............ 103

Green 28, 33, 58, 70, 11 is, 143 , f. 144

Germination .......... 38

Seed................. 34

Marsh.................... 148

Smut ................. 103

Whorled, Germination....... 42

Yellow .......24,33, 62, 70, 142

Frank ................ 95

Franseria

discolor ............... 235

Hookeriana .............. 235

tomentosa ................. 235

Distribution ............. f. 77

White-leaved ............... 235

Free placenta............... 130

Fremont's Goosefoot.........59, 168

French weed ......2, 16, 67, 179-180

Eradication ............ 102

Germination ............. 38

Froelichia floridana.........171-172

Fruit ................ 132.133

Aggregate ................. 132

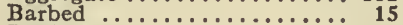

Dehiscent ................ 132

Dry .................. 132

Fleshy ................... 133

Hooked ................. 15

Indehiscent ............... 132

Keylike .................. 132

Multiple ................. 132

Paired ................. 133

Simple . . . . . . . . . . . . . 132

Stone .................. 133

Winged ................. 14,16

Fuchsia................. 204

Fuller's teasel........... 19, 74, 115

Fungi

Destruction of ........... 94

On weeds................ 4

Funiculus .............130, 133

Funnel-form corolla.......... 128

Fusiform root............... 116

Galinsoge ..............58, 70 parviflora $\ldots \ldots \ldots \ldots \ldots \ldots \ldots \ldots$........... 70

Galium ................. 228

Gamopetalous flowers......... 126

Garden Chamomile.......... 244

Garden, Weeds of ......... 58-59

Extermination ............ 93

Garlic .............. ${ }^{72}$

Field ............... 72

Meadow ................... 159

Wild ...........57,67, 159

Garner, E. R.............. 12

Gaura................ 204-205

biennis .................. 204

coccinea ...............204-205

Hairy .................... 204

parviflora ................ 204

Purple ..................... 204

GERANIACंËË . . . . 136, 191-192

Geranium

carolinianum ............. 59

seed of ................ f. 21

Germander ... $8,37,70,115,218-219$

Germicide ................. 99

Germination, delayed ......... 38-40

Geum

album ................ 68

canadense ................ 186

Gilia .................... 128

Girard, Aime................ .94, 95

Glomerule ................ 125

Glycyrrhiza lepidota............. 71

Goff . . . . . . . . . . . . . 55

Golden Hawkweed ............ 82

Goldenrod .....13, 52, 58, 59.70, 231

Canadian ............11,52

Yellow-flowered ............ 52

Goosefoot .....58, $70, i 13, i 33,169$ Eradication ............ 95

Common ............... 70

Fremont's ..........168, 59, 70

Hybrid ................ 70

Gosmore ...........251, f. 251

Gossypium herbaceum........... 200

Gourd .................. 133

Grain-fields

Spraying . . . . . . . . . . . . 101

Weeds . . . . . . . . . . . . . 5 57-58

GRAMINEAE ....... 135, 139-156

Grape ..............119, 124. 133

Grass

Barnyard $16,28,30,33,56,62,142$

Beard ............... 68

Bermuda ................. 68

Blue .......... 15, 28, $30,62,93$

Canadian ............. 35

English ............. 152

Kentucky

Impurities $\ldots \ldots \ldots \ldots \ldots 35$

Seed ............... f. 36

Brome. .............. . 56, 115

Annual ................. 62

Awned. $\ldots .4,5 i ; 59,6 \ddot{8}, 76,115$

Downy............... 153

Hairy ................68. 115

Quaking.........5 $7,68,76$

Canary ................ 145

Candy................... 151-152

Carpet ............... 68

Cheat........................... 152

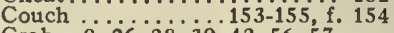

Crab $9,26,28,30,42,56,57$,

$58,59,62,69$

Eradication ........101,103 
Grass, Crab, Germination ...... 42 Smooth

$31,33,62,69,139-140$, f. 140 Sprouting ............ 142

Crowfoot...............59, f. 150 Dog's tail

Crested ............. 36

Dropseed

Eradication.......... 110

Diffuse.................. 70

Mexican .........7\%, 147-148

Spiked $\ldots \ldots \ldots \ldots \ldots \ldots \ldots \ldots \ldots, 70$

Family .............139-158

Finger $\ldots \ldots \ldots \ldots \ldots \ldots \ldots, 141$

Foxtail $10,16, \mathrm{f}, 17,24,26,30$,

$51,56,57$

Eradication ..96, 98, 101, 111

Germination ..........442

Bristly .............. 143

Floating $\ldots \ldots \ldots \ldots \ldots \ldots \ldots, 70$

Green

$28,33,58,70,115,143$, f. 144

Germination .......... 38

Seed ................. f. 34

Marsh ............... 148

Whorled

Germination ......... 42

Yellow ......24, 33, 62, 70, 142

Hair $\ldots \ldots \ldots \ldots \ldots \ldots \ldots . . \ldots \ldots$

Holy ................ 145-146

Johnson .............. 79, 71, 139

Distribution ..........f. 82

Needle $\ldots \ldots \ldots \ldots \ldots 18,64,72,146$

Nut $\ldots \ldots \ldots \ldots \ldots \ldots 4,28,58,116$

Northern ......72, 157, f. 158

Southern ........72, 157-158

Old Witch .....28, $31,33,141-142$

Orchard ............. 36

Pearl, Blue................ 36

Pigeon $f .9,16,28,31,32,58$, $62,115,142$

Eradication ........98, 111

Germination ............. 42

Porcupine ............. 146

Poverty ........59, 73, 146-147

Southern ........... 51

Quack $8,10,12,13,19,23,27$, $31,58,65,67,73,87,93$, $116,117,153-155, f .154$

Distribution..........f. 82

Eradication........87, 99-99

Germination ........42, 104-107

Rootstock .............. 118

Seed ..................... 37

Stem ..................... 117

ז́ed Top .................. 149

False .............28, 30

रib (See Rib Grass)

Rice-cut...........73, 82, 145

Rus:

Sheathed ............148-149

Small $\ldots \ldots \ldots \ldots \ldots \ldots \ldots \ldots \ldots \ldots 149$ Rye

Perennial............ 78

Winter .................. 115

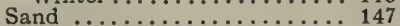

Sleepy ............... 64
Grass, Spear............. 73

Annual .............. 61

Southern ............ 151

Squirrel $\ldots \ldots \ldots \ldots \ldots \ldots \ldots .78$

Squirrel-tail $4,16,24,26,57$, $58,62,67,82,85$, f. 115 , $155-157, f .156$

Distribution ............. 82

Eradication ............111-112

Stink ..................... 74

Stipa, Western ............ 146

Switch $\ldots \ldots \ldots \ldots \ldots \ldots \ldots \ldots . .74$

Turkey-foot ............ 59

Vanilla .............75, 145-146

Velvet.............36, 75, 78

Wire......24, 150-151, f. 150,152

Witch .......28, 31, 75, 141-142 Grass Seed, Dealers' Association,

Wholesale ............ 49

Gray, Asa............... 83, 85

Greasewood ............... 167

Great

Mullein .............. 224

Ragweed $11,13,16,26,58,59$

$62,73,115,234$

Germination ........38,41.42

Willow-herb .............. 204

\section{Green}

Foxtail 28, 33, f. 34, 38, 58, 70,

115,143, f. 144

Hellebore ............57, 64

Grindelia ..................... 70

squarrosa.............

Gromwell, Corn.........57, 58, 216

Ground

Bur-nut .............193, f. 193

Cherry $\ldots \ldots \ldots \ldots \ldots \ldots \ldots \ldots \ldots, 18$

Ivy $\ldots \ldots \ldots \ldots \ldots \ldots \ldots, 24,219$

Growth

Definite annual ......... 117

Indefinite annual $\ldots \ldots \ldots \ldots \ldots .118$

Gulf States, Garden weeds.... 59-60

Gumbo .................201-202

Gumweęd.............70, 231

Gutierrezia ................... 70

Gymnosperm ................ 129

Gynandrous stamens.......... 128

Hair Grass............... 35

Hairy

Brome grass..........68, 115

Gaura .................... 204

Halsted, B. D.....4, $12,65,66,67$

Hanlein $. . . \ldots \ldots \ldots \ldots \ldots \ldots, 40$

Hard maple.................... ${ }_{199}^{40}$

Harebell ..................128, 229

Hare's ear.................... 100

Hawkweed ............... 85

Golden ..................... 82

Orange............ 65,72

Eradication............95, 97

Hazelnut ................ 133

Head .............125, f. 125, f. 126

Heart's-ease .........70, 203-204

Hedge

Bindweed .....24, 211-212, f. 212

Mustard $\ldots \ldots \ldots \ldots \ldots .72,115,183$

Heinrich ................. 95 
Page

Helenium

autumnale............ 53, 73

Hoopsii.................. 73

tenuifolium............53,73

Distribution ............. f. 79

\section{Helianthus}

annuus......59, 74, 78, 238, \& 239

Germination .......... 42

debilis ................. 74

grosseserraius....52, 74,239, f. 240

Maximiliani ............ 239

petiolaris............59,74, 238

tuberosus............ 52, 68

Heliopsis scabra ..........11, 236-237

Heliotrope.............71, 80

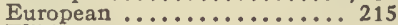

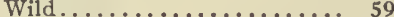

Heliotropium

europaeum............71, 215

indicum ............... 80

Hellebore

False .................. 64

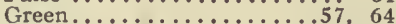

Hemlock ............663,70

Bulb-bearing ............... 63

Poison .............6. 64, 205

Water..............64, 206, f. 207

Hemp....5, 10, 64,81, 126, 161, 225

Indian........64,69, 208-209

Water....................... 171

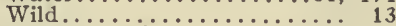

Henbane, Black.........5, 63, 71

Henbit................58,59

Herbicide ..............61, 94

Ammonium sulphate........ 95

Basic slag ....................... 95

Blue vitriol.............. 95

Carbolic acid ..................... 95

Copper sulphate.......90,94,95

Formaldehyde ............ 95

Iron sulphate . . . . . 61, 90,93,95

Lime, slaked............... 95

Potassium sulphide......... 95

Salt .................. 95

Sodium nitrate................ 95

Sulphuric acid ............. 95

Hermaphrodite flowers........ 125

Heuse ................ 95

Hibiscus Trionum ..........202, f. 202

Hickory ...........117, 118, 125

Hieracium a urantiacum .....72, 254

Hierochloe odorata ........75, 145-146

Highways, as seed carriers .... 25-26

Hilgard, Dr. Eugene... . . . . . . 80 Hoary

Plantain ............... 40

Puccoon .................216-217

Vervain.............217, f. 218

Hog Millet, Legislation ........ 48

Hogweed ...................... 173

Hogwort............64, 193-194

Holcus lanatus. ..............36,75

Holy Grass ................145-146

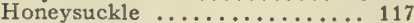

Family ................. 228

Hop Clover....................... 69

Low ................... 189
Page

Hordeum

caespitosum...........557, 157

jubatum..55, $57,68,155-157$, f. 156

Germination ........... 42

murinum...........5 57, 68, 78

nodosum .......................... 68

pratense ................ 78

pusillum........6.68, 155, f. 155

secalinum................ 157

Horehound .............. 59, 219

Water, Germination ........ 42

Horizontal ovule............ 130

Horse

Chestnut. . . . 64, 117, f. 119, 120

Mint............... 22, 28, 30

Nettle $7,12,13,54,58,67$, $71,83,91$, f. 221,222

Eradication .....91,94, 109-110

Germination .......... 41

Legislation ............ 43

Horse-radish $7,8,24,26,58,64,81,184$

Horsetail ...........57, 64,71

Family .................... 138-139

Horseweed $11,13,24,26,58,59$,

$81,82,115,222$

Low .............233, f. 233

Howitt, J. E..................... 108

Humus, Loss of ............. 6

Hura crepitans.............. 15

Husbandry, Alternate......... 50

Hyacinth, Water............ 79, 84

Hybrid Goosefoot ............. 70

HYDROPHYLLACEA $\dot{E} 137,214-215$ Hygroscopic movements of Seeds 15

Hyoscyamine ............. 5

Hyoscyamus niger............. 71

HYPERICACEAE … 136, 202-203

Hypericum perforatum 74, 203, f. 203

Hypochaeris ..........61,62 radicata.............251, f. 251

Hypogaeous ................ 134

Hypogynous flowers.......... 127

Illinois, Weeds in..........68-75

Impatiens ................. 15

Indehiscent fruit . . . . . . . . 132

Indeterminate inflorescence.. 124-125

India, Weed emigrants from. . . .80, 81 Indian

Currant.............71, 228

Hemp...64, 69, $126,208-209,225$ Mallow $36,58,78,84,87$, f. 131 ,

200, f. 200

Eradication.................... 112

Tobacco ................. 64

Indiana, Weeds in ........67, $68-75$

Indigo, wild ............... 64

Indigofera tinctoria............ 71

Inferior flower ............. 127

Inflorescence................. 124

Determinate ...........124, 125

Indeterminate ..........124, 125

Innate filament. ............. 129

Introrse anther................ 129

Iowa,

Legislation against weed pests 66-67

Noxious weeds in.........68-75

Thistle .............. 52 


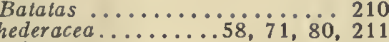

Distribution........... f 77

leptophylla .............. 211

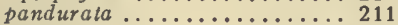

purpurea ...........28,80, 211

Iresine paniculata ........... 171

Iron sulphate

$61,90,93,95,96,100-103,112$

Ironweed $\ldots .52,58,71,115,230, \mathrm{f} .230$

Irregular flowers . . . 125, f. 127, f. 128

Italy. Weeds from ........81,82 Iva

axillaris...........70, 233, f. 234

ciliata................59,70

Ivy

xanthifolia.............70, 233

Ground...............24, 219

Japanese................... 118

Poiscn ...............26, 64,73

Ivy-leaved Morning Giory.....221

Japanese Ivy . . . . . . . . . . . . f. f. 118

Jatropha stimulosa.........74, 193

Java, Weeds of ............ 81

Jewel-weed ................... 15

Jimson Weed $5,28,30,62,63,64$,

$71,78,80,115$

Purple...............64,71

Wright's .................... 71

Joe-pye Weed............... 231

Johnson Grass.......... 19, 71, 139

Distribution ................. 82

Jones, L. R. $85,95,96,97,98,99,186$

Juba Bush . . . . . . . . . . . 171

JUNCACEAE .......... 135, $158-159$

Juncus tenuis........73, 159, f. 159

Juniper, Common............ 63

Kabsch .................. 81

Kansas weeds ............ 68-75

Kentucky

Blue Grass.............35, f. 36, 46

Coffee Tree................. 64

Weeds..............67, 68-75

Kerosene as herbicide........ 95

Ketmia, Bladder......28, 202, f. 202

Keylike fruits ............. 132

King, Charlotte M.........27, 38

Kinghead ........5, f. 24, 67, 97

Eradication ............. 101

Knapweed..............250

Black ................... 250

Brown .................. 250

Knotgrass, See Knotweed.

Knotweed...........96, 164, f. 165

Bushy ............................ 165

Dooryard...........62, 71,115

Eradication........... 100

Erect .................. 71

Larger ................. 164

Slender ................. 71

Kochia................. 168

Kochia scoparia..........70, 168

LABIATAE .........137, 218-220

Labiate corolla............. 128

Lactuca

canadensis ..................... 254

pulchella .................. 71

scariola ...... . 7 i, $253-254$ f. 253

virosa

Lady's slipper, Yellow........... 64

Lady's Thumb $13,28,30,33,56$

Germination

$58,71,165$, f. 166

Lamb's Quarter

$5,10,24,30,33,58,133,169$

Eradication...........99, 100

Germination .............. 39, 42

Lamium a mplexicaule.... .59, 72, 219

Laportea canadensis........... 72

Lappula

echinata .............215-216

floribunda................ 192-16

virginiana ................. 216

Large Pepper Grass........... 180

Larger

Knotweed .............. 164

Ragweed. See Greater Ragweed.

Larkspur . . . 64,f. 128,f. 131, 132, 178 Blue ............... 71

Carolina .................... 71

Western.................... 71

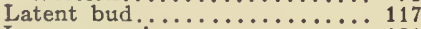

Lawn, spraying .................... 101

Weeds, of ............... 62

Leaves

Acuminate..........121, f. 123

Acute.................... 121, f. 123

Aristate $\ldots \ldots \ldots \ldots \ldots \ldots \ldots \ldots \ldots 122$

Auriculate............. fi 123

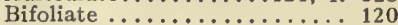

Biternate................... 120

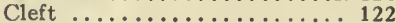

Cordate............. 121, f. 123

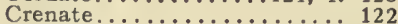

Cuneate............... 120, f. 123

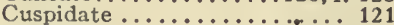

Divided ................... 122

Elliptical ................ 120, f. 123

Emarginate................ 121

Entire ..................... 122

Halberd-shaped..........f. 123

Hastate .................. 121

Incised . . . . . . . . . . . . . . 122

Kidney-shaped.............. 121

Lanceolate............. f20, f. 123

Linear . . . . . . . . . . . 120, f. 123

Lobed............ fi22, f. 121, f. 122

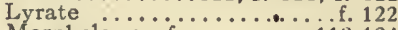

Morphology of ........... 118-124

Mucronate.............121, f. 123

Netted-veined...........119,f. 120

Obcordate............. 121,f, 123

Oblanceolate.............. 120, f. 123

Oblong ................. 120, f. 123

Obovate................ 120, f. 123

Obtuse................ 121,f. 123

Orbicular.................. 120

Ovate........................ 120

Palmately netted-veined.119, f. 119

Parallel-veined........119,f, 121

Parted ................. 122 
Page

Leaves, Peltate .........121,f. 123 Pinnately netted-veined 119, f. 119 Pinnatisect ..............f. 122 Radiate-veined............f. 122 Reniform .............. 121

Repand ................ 122

Sagittate............121, f. 123

Serrate................ 122

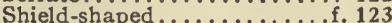

Spatulate............120, f. 123

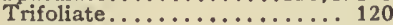

Truncate............121, f. 123

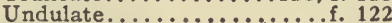

Wedge-shaped.............f. 123

Leek, Wild ................ 72

Leersia

oryzoides.............82, 145

virginica .............. 73

Legislation

Seed-control Law....... 43, 45-49

In Canada.............. 49

Iowa...............45-49

Kentucky .......... 49

Maine ............. 49

Michigan............ 49

New York............. 49

North Dakota ......... 49

Washington ............ 49

Wisconsin............ 49

Weed Law ..................43-44

Legume $\ldots \ldots \ldots . . . . .132$

LEGUMINOSȦ …87, $136,187-191$

Lemna .................. 15

Leonurus cardiaca............7i, 219

Lepachys pinnata............ 69

Lepidium

a petalum .....28,55,72, 180,f. 181

virginicum .......33, 36, $55,56,180$ Impurity in alsike and blue

Lepiota grass .............. f. 35

Lettuce

Blue ...............71,115

Canadian ........................ 13

Prickly $10,13,24,58,59,71$

$84,96,115,253-254$, f. 253

Virosa ................. 71

Wild................ 126,254

Licorice, $\dot{W}$ ild......... $20,59,71,116$

Ligulate corolla .............. 128

LILIACEAE . . . . . . . . 135, 159-160

Lily

Family . . . . . . . . . . . 159-160

Stem ............................... 117

Lily of the Valley..........64, 124

Lima Bean................. 64

Lime, slaked, as herbicide......95,98

Linaria vulgaris.........224, f. 224

Linum usitatissimum Legislation .............

Liquorice. See Licorice.

Lithospermum arvense..............69, 216 canescens ..............216-217

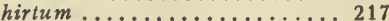

Little Barley ............ 155 , f. 155

Live-forever …..................... 155
Page

Lizard's Tail . . . . . . . . . . . . . 160

LOBELIACEAE $\ldots \ldots \ldots \ldots \ldots .137$

Loco Disease .................... 189

Loco Weed, Stemless......... 64, 71

Locust

Black ............... 63

Honey, Germination........ 42

Lolium

italicum............ 46,47, 48

perenne. ....36, 46, 47, 48, 78, 153

temulentum .............. 153

Low

Hop Clover................. 189

Horseweed ...........233, f. 233

Lychnis

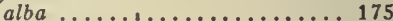

Flos-cuculi.................. 175

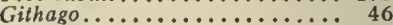

Vitality............. 38

vespertina ............... 46

Lycopus rubellus, Germination.. 42 Lygodesmia

juncea . . . . . . . . . . .73, 254

Rushlike .......................... 254

Madder Family ...........227-228

Madia californica ...........240-241

Mallow...............24, 201

Germination .............. 41

False..............200-20t

Family ........ $5,36,87,199-202$

Indian $36,58,78,84,87, f .131$

Small. See Cheeses.

200 , f. 200

MALVACEAE ............. 136

Malva rotundifolia ........69, 201

Vitality ................ 38

Malvastrum coccineum ........200-201

Man as seed carrier . . . . . . . 15-16

Mandrake ................. 64

Manitoba Weeds.............78, 79

Manure, Seeds buried in ... . . .41-42

Maple ......14, 119, 129, 132, 199

Curly ................ 199

Hard .................... 199

Sugar $\ldots \ldots \ldots \ldots \ldots \ldots \ldots \ldots \ldots 199$

Maps howing distribution of weeds ..........77, 79, 82

Marigold

Fetid ......662, 70, 115, 242-243

Marsh ............... 64

Marre .................. 95

Marrubium vulgare......59, 71, 219

Marsh

Elder ...51, 59, 62, 70, 83, 115 ,

Small-flowered.........233-234

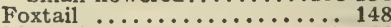

Marigold .............. 64

M uhlenberg ............. 147

Marshall, Humphrey.......... 85

Martynia proboscidea ......... 74

Maryland, Garden weeds of.... 59

Matricaria Chamomilla........ 69

Mayweed ..........10, 11, 30, 243

Maximilian's Sunflower ....... 239 
Meadow

Elder .................. 70

Fescue, Impurities in. ....... 35 Legislation ...........46-47

Garlic................. 159

Rue ...............29, 30, 120 Sunflower

$6,52,58,62,74,239$, f. 240

Meadows, Weeds of ......50-57, 92

Medicago

denticulata ..........46, 47, 80

Germination ........... 42

hispida ..............69, 190

lupulina

$28,33,46,47,71,190$, f. 190

Germination .......... 42 sativa..............28, 46,47

Medicinal weeds............ 5

Medick

Black .....59, 71, 115, 190, f. 190

Toothed ............... 190

Melilotus

alba $\ldots \ldots \ldots \ldots 28,46,55,74,189$

Germination ........, 42 officinalis ..........46, 74,189

Mentha piperita.......... 220

Mercury, Three-seeded......... 194

Mericarp ............... 133

Mesquit, Germination......... 42

Mexican

Dropseed . . . . . . . . .70, 147-148

Fireweed $\ldots \ldots .23,59,70,115,168$

Poppy ................ 73

Tea........58, 59,71,80, 168

Michigan weeds ..........68-75

Micropyle ..............130, 133

Mndew, Downy............ 103

Milk

Purslane .............. 58

Spurge $\ldots \ldots \ldots \ldots \ldots \ldots \ldots, 58$

Thistle $\ldots \ldots \ldots \ldots \ldots \ldots \ldots .6 . \ldots$

Milkweed $7,12,13,16,24,26,54$, $57,91,109,115,119,125$,

210, f. 210

Eradication .........98, 109

Germination ...............39-40

Root ............... f. 11

Climbing ............... 71

Common .............. 71

Family ................209.210

Showy ............... 209

Swamp ................54, 209

Western ............. 71

White ...............209-210

Millet $\ldots \ldots \ldots \ldots \ldots \ldots \ldots, 28,30$

Germination ..........., 42

Common, Legislation........ 48

Hog, Legislation ........... 48

Pearl, Legislation.........., 48

Millspaugh, C. F.............6, 67

Mimulus Jamesii.............. 71

Minnesota Weeds.............68-75

Mint .................125, 128

Family ...........36, 218-220

Horse $\ldots \ldots \ldots \ldots \ldots$ f. $22,28,30$

Mississippi Valley garden weeds 58-59

Missouri weeds...........68-75
Mist Flower............. 231

Mistletoe ................... 116

Molinia caerulea............. 36

Monarda fistulosa............. 22, 28

Monkey Flower ............ 71

Monkshood ................. 64

Monocotyledon ............ 134

Monocotyledonous $\ldots \ldots \ldots \ldots .134$

MONOCOTYLEDONEÄE......135

Monoecious flowers........... 125

Montana weeds ...........68-75

Moonseed ...............64, 126

Moore ................. 96

Morning Glory $4,7,9,12,28,30$, $58,59,71,109,116,212$

Eradication ....996, 98, 112-113

Blue $. . \ldots \ldots \ldots \ldots \ldots \ldots \ldots, 71$

Bush .................... 211

Common ..........54,80, 211

European ............. 71

Family ............... 54

Ivy-leaved $\ldots \ldots \ldots \ldots \ldots \ldots, 211$

Southern ............. 58

Wild $24,26, f$. $113,211-212, f ., 212$

Eradication ..........112-113

Morse, W. J............... 95

Moss Rose................... 176

Moth Mullein............. 224

Motherwort............ $71,219-220$

Mountain Barley........... 68

Mouse Chickweed............ 174

Mouse-ear.. ............ 58

Mouse-tail

Germination ........... 40

Mugwort

Common .............. 245

Western $\ldots \ldots \ldots \ldots \ldots \ldots \ldots \ldots \ldots \ldots, 71,245$

Muhlenberg, Marsh.......... 147

Muhlenbergia

diffusa ................ 70

glomeraia....................33, 58

mexicana ........33,58, 70, 147

racemosa .........70, 148, f. 148

Mullein .......... $7,10,24,62,115$

Common .............. 71

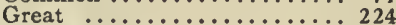

Moth .................. 224

Multiple fruit................ 132

Musky Alfilaria.......... 192

Mustard 2, 4, 5, 23,33, $46,56,57$, $62,64,67,81,88,94,115,132$ Eradication

$95,96,97,100,101,102,112$

Ball ................ 181

Black $24,30,46,72,76,182, \hat{f} .182$

Common .............. 72

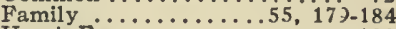

Hare's Ear.............. 182

Hedge $\ldots \ldots \ldots \ldots \ldots 72,115,183$

Germination ..........42

Eradication ............... 100

Treacle ................. 183

Tumbling

$26,56,57,72,115,183$, f. 183

Wild $\ldots \ldots \ldots \ldots . . . .31,46,66,76$

Germination .......... 38

Legislation ............. 43 
Page

Mustard, Worm-seed Eradication 95

Myagrum sativum........... 81

Myosurus minimus, Germination of $\ldots \ldots \ldots \ldots \ldots \ldots \ldots, 40$

Napiform root............... 116

Narrow-leaved

Sneezeweed ...53, 59, 73, 77, 242

Verbena .............217-218

Nasturtium officinale......... 69

Navarrelia squarrosa ............ 214

Nebraska weeds ...........68.75

Needle Grass......... 18, 64, 72, 146

Nelson, Aven.............. 67

Nelson's Thistle............... 115

Nelumbo ................ 15

Nepela

Cataria .............28, 219

hederacea................. 219

Neslia paniculata............. 181

Nettle

Bull .................. 193-222

Dead .............58, 59, 72-219

Family ................. 160-162

Horse $i, 12,13,54,67,69,71$, $83,91, f .221,222$

Eradication ........91, 109-110

Slender......72, 115,161 , f. 161

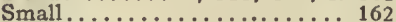

Spurge .................. 74

Stinging..........64, 72, 161

Vervain ................ 75

Western .........72, 116, 162

Wood ................... 72

New Engliand

Aster ................ 232

Garden weeds............ 58

Nicotiana glauca.............. 74

Nigger-head ..............83, 237

Night-flowering Catch-fiy

$23,33,46,58176$

Nightshade $\ldots \ldots \ldots \ldots \ldots \ldots \ldots .15$

Black ......13, 16, 63, $72, \mathfrak{f}, 220$

Common ........220-222, f. 220

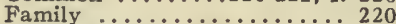

Silvery-leaved ............. 72

Three-flowered ............. 72

Nimble Will $\ldots .33,58,90,93,1$ i 6,147

Nobbe ................ 40

North Dakota weeds.......67, 68-75

Noxious weeds............6.65-75

Tables of ............68-75

Nucellus................... 130

Nursery-stock as seed-carrier.... 19

Nut .................... 133

Grass .......... $4,28,58,116$

Northern ...72, 115,157, f. 158

Southern .......72, 157-158

NYCTAGINACEAE . . 136, 172-173

Oak .................. 119

Oat field................. 4

Grass, Legislation........... 48

Oats ........... $3,5,23,139$

Germination ........... 42

Legislation ............ 48

Wild $18,19,31,57,58,64,67$,

$72,88,149-150$
Page

Oats, Germination........... 38

Oenothera .................. 204

biennis .......73, 82,205 , f, 205

Vitality .............. 38

Ohio weeds ................ 68.75

Okra .................... 201-202

Old-witch Grass ...28, 31, 3.3. 141-142

ONAGRACEAE ......136; 204-205

Onion ................ 117 Wild $\ldots \ldots \ldots \ldots \ldots \ldots \ldots \ldots 9,59,72$

Opium ................... 64

Orach .........60, $72,169, \mathrm{f}, 171$

Orange

Hawkweed ............65. 72

Eradication ..........95.97

Orchard Grass

Impurities in . . . . . . . 36, 46, 47

Legislation ...........46,47, 48

Orchids ................. 116

Ornithogalum

umbellatum .........61, 74, 160

Distribution.............. f. 79

OROBA NCHACEA $\ldots \ldots \ldots 137,225$

Orobanche

minor ............... 225

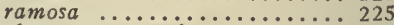

Orthotropous ovule........... 131

Orton, W. A.............95, 99

Osage Orange................. 64

Oswald, E. I.................. 41

Ovary ................... 129-130

Ovule

Coats ................ 130 Morphology of ............129.131

OXALIDACEAE ............. 191

Oxalis ........................ 15

corniculala ............... 191

stricta ................. 191

Yellow ............. 10. 13

Ox-eye ................236-237 Daisy $16,19,24,52,67,72,82$,

244, f. 244

Oxybaphus

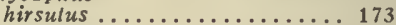

linearis ...................... 173 nyctagineus

$28,31,70,172-173, \mathrm{f}, 173$

Oxytropis Lamberli .......... 71

Oyster

Plant .................. 72

Vegetable ............. 17,59

Pale Dock . . . . . . . . . . . . 163

Panicle ............. 125, f. 126

Panicum

capillare ......28, 33, 75, 141-142 dichotomiflor um ........... 142 glabrum .................. 46 miliaceum, Legislation......... 48 virgatum ............... 74

Pansy ..............78, 203-204

PAPAVERACEAE ..... 136, 178-179

Papilionaceous flower.....f. 127, 128

Parasitic plants............ 116

Parietal placenta ............ 130

Parielaria pennsylvanica....... 72 
Parsnip ...........7, 54, 115, 133 Garden ............... 11 Water ..............4, 64, 72 Wild $\ldots \ldots 11,26,67,72,206-207$ Partridge Pea 26, 28, 31, 64, 72, 188 Paspalum platycaule......... 68

Pasque Flower............... 64

Pastinaca sativa........72, 206-207 Legislation ............. 43

Pastures

Result of overstocking . . . . . 51-52

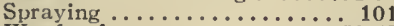

Weeds of .............. 50-57

Patience Dock............669, 163

Pea ................. 132, f. 133 Partridge $\ldots 26,28,31,64,72,188$ Sweet $\ldots \ldots \ldots \ldots \ldots \ldots \ldots \ldots \ldots 128$

Peach ...............64, 133

Peach-leaved Dock..........12, 163

Pearl

Grass, Blue............. 36

Millet, Legislation............ 48

Pea-vine Clover.............. 47

Pellitory Parietaria........... 72

Pennisetum typhoideum, Legislation .......................

Pennsylvania Smartweed

$13,58,166$, f. 167

Pennycress . .57, 100, 179-180, f. 180 Field, Germination......... 40

Pepo ................... 133

Pepper ................. 133

Family ............... 160

Water ............................ 166

Pepper Grass $\ddot{4}, 15,18, \ddot{2}, \ddot{2}, 28,31$, $36,55,56,72,115$

Eradication............ 100

Large . . . . . . . . . . . . . 180

Small ............. 180, f. 181

Virginia ............... 72

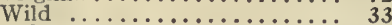

Germination ............ 42

Peppermint ........... 12, 59,220

Pepper Weed.............72, 214

Perennial ................ f. 8

Ragweed ............... 59

Rye .......................... 78

Sow Thistle................ 67, 73

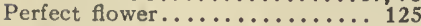

Pericarp ................ 132

Perigynous flower.......... 127

Perisperm ............... 133

Dersia, Weeds of ............ 81

Persicaria ............... 56

Phalaris canariensis ........ 145

Philippine weeds........... 81

Phleum pratense........28, 31, 33

Legislation .............. 48

Phlox Family............128, 214

Phytolacca decandra......59, 73, 172

PHYTOLACCACEAE ...... 172 Pigeon Grass

$9,16,28,31,32,58,62,115,142$

Eradication...........98, 111

Germination .............. 42
Pigweed

Page

$10,24,31,58,59,65,73,115$

Eradication ....95, 98, 99, 100

Germination .......... 42

Prostrate ........... 17i, f, 172

Eradication ........... 96

Rough ................. 13

Spiny $\ldots \ldots \ldots \ldots \ldots \ldots \ldots \ldots \ldots{ }_{58}$

Stem of ............... 117

Thorny ............... 73

Winged................. 15,167

Pine ................. 129, 133

Pineapple weed .............. 59

Pink ................ 124, 130

Family ............. 173-176

Hardy $\ldots \ldots \ldots \ldots \ldots \ldots \ldots . . \ldots \ldots$

PIPERACEAE .........

Pistil, compound.............. 132

Pitchfork, Seed of .............. 21

Placenta ................. 130

axile $\ldots \ldots \ldots \ldots \ldots \ldots \ldots \ldots \ldots 130$

free $\ldots \ldots \ldots \ldots \ldots \ldots \ldots \ldots \ldots . . \ldots \ldots$

parietal ................

Plant community ............ 1

PLANTAGINACEAE $\cdots 137,225-227$

Plantago

aristata ... . 28, 33, 72, 227, f, 228

Germination .......... 42

Legislation ............... 46

lanceolata ..........28, $33,46,52$

Germination ........... 42

Legislation . . . . . . . . . . 43, 46

major .......... $22,26-227$

Vitality .............. 38

media, germination ........... 40

Rugelii.......31, $3 \dot{3}, \mathrm{f}, 22 \dot{6}, 227$

Germination .......... 42

virginica $\ldots \ldots \ldots \ldots \ldots \ldots \ldots . \ldots . \ldots . \ldots 59$

Plantain ..........10, 11, 13, 125

Bracted $28,30,32,33,55,115$,

Germination

227, f. 228

Legislation .............. 46

Buckhorn, Legislation......... 46

See also Buckhorn

Hoary, gcrmination......... 40

Legislation ............. 43

Narrow .................... 67

Rib or Ribbed ...........52, 67

Rugel's .....28, $3 \dot{3}, 33, \dot{f}, 226,227$

Germination .......... 42

Virginia ................ 59

Plum ................. 133

Plumule ................ 134

Poa

annua................. 61

compressa ............. 68,152

Legislation .......... 46, 47

pralensis ................ 28

Legislation.............. 46

serotina .................... 28

Poison

Darnel ................ 153

Hemlock ............. 64,205

Ivy $\ldots \ldots \ldots \ldots 26,64,73,116,198$

Poisonous Weeds..4, 53, 54, 57, 63-64 
Page

Pokeweed ..........5,59, 64, 72

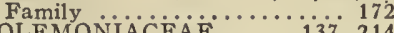

POLEMONIÄCEÄ …... 137, 214

Pollen ...........129, f. 129, 130

Pollinium .................. 129

Polycotyledonous ............ 134

Polygamous flower........... 126

POLYGONACEAE . . . . 136, 162-167

Polygonum ................ 80

acre ................. 73

aviculare............ 71,164, f. 165

Convolvulus...28, 58, 68, f. 116,166

erectum................. 164

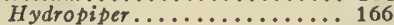

Vitality .............. 38

hydropiperoides...........72, 166

la pathifolium..........166, f. 167

Muhlenbergii .........52,74, 165 pennsylvanicum

$28,70,165,166$, f. 167

Persicaria $28,33,56,71,165$, f. 166

Germination .......... 42

ramosissimum ........... 165

virginianum ............. f. 22

Polypetalous flower........ 126, f. 128

POLYPODIACEAE ........135, 137

Polypogon monspeliensis........ 68

Pome ................. 133

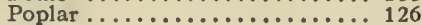

Poppy ................64, 130

Family ................ 178-179

Mexican ................ 73

Opium .................. 179

Prickly..........59, 60, 64, 73

Smooth-pointed corn. . . . . . 179

Wild ................. 116

Porcupine Grass.............. 146

Portulaca

grandiflora ................ 176

oleracea........38, 79 , i77, f. 178

Vitality .............. 38

PORTULACACEAE.....136, 176-177

Potassium sulphide, as herbicide 95

Potato ................. 119

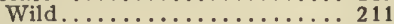

Sweet.......... $5,116,117,210$

Potato Scab.............. 99

Potentilla

Anserina.............73, 186

argentea, Germination........ 40

fruticosa................ 186

monspeliensis... 28, 33,183, f. 186

Poverty grass . . . . . 59, 73, 146-147

Southern ............. 51

Prairie

Bitterweed ............. 115

Ragweed .............. 73

Rose................... 187

Sunflower.............238-239

Thistle ..............247-248

Prickly

Lettuce $10,13,24,58,59,67$

$71,84,115,253-254$, f. 253

Eradication............ 96

Poppy...........59, 60, 64, 73

Sida ..................201
Page

Primrose

Evening. . . . . 13, 73, 205, f. 205

Family ................ 204-205

Prostrate, Pigweed.......... 171, f, 172

Eradication.............. 96

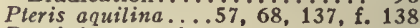

Puccinia suaveolens........... 103

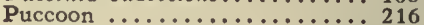

Hoary .................. 216-217

Rough................... 217

Pulse Family ............36, 187-191

Pumpkin ................ 1

Pumpkin-peg ................. f. 134

Purity of seeds, Standard of ... .47-49

Purple

Fireweed ............. 70

Foxglove ........... 64, 224-225

Gaura .................. 204

Jimson Weed............64,71

Stramonium ......222-223, f. 223

Purple-flowered Rush......... 73

Purslane 10, 24, 58, 65, 73, 78, 79 , $82,130,132,177$, f. 178,225

Eradication.............. 100

Family ................ 176-177

Milk................... 58

Pusley ............ $58,80,81$

Pyricularia gricea ............ 103

Pyxis ....................... 132

Quack Grass $8,10,12,13,19,23$,

$$
27,31,46,58,65,87,93 \text {, }
$$

$116,117,153-155, \mathrm{f} .154$

Distribution ............ 82

Eradication..........87,96, 97

Germination .............. 42

Legislation .............. 43

Rootstock ......................... 118

Seed..................f, 37

Stem ................. 117

Ouaking Brome Grass.......57, 68, 76

Queen Anne's Lace........... 207

Quercus rubra, Vitality of....... 38

Raceme................ 124, f. 125

Radicle ................... 134

Radicula Armoracia.............. 184

Radish ................ 80

Wild....................... 24

Ragged Robin .............. 175

Ragweed $10,11,17,24,25,31$,

$33,51,57,64,67,87$, f. 125

Eradication...........95, 100

False ................. 59

Great $11,13,16,20,58,59,320$,

$73,87,115,234$

Germination........38,41,42

Perennial................ 59

Prairie .................. 73

Small $13, \mathrm{f}$. $17,26,58,59,620$ $73,100,115,234$, f. 235 , f. 236

Western .............234-235

Germination .............. 39-40

Railways, as weed-carriers . . . 24-25

RANUNCULACEAE ...136, $177-178$

Ranunculus

abortivus .............177-178

acris .................. 178

fascicularis ................ 178 
Ranunculus, repens........... 69 sceleratus........69, 177, f. 179 seplentrionalis ............ 171

Rape...................46, 98 As weed exterminator........ 108 Legislation ............. 41 Raphanus Raphanistrum..... 82

Raspberry ............. 137 Black ................ 187 Wild Red................ 188 Rattle Box..........64, 73, 188 Red

Cedar................ 14

Clover f. $25,29,31,33-34$, f. 35,46 River weed, Eradication...... 95 Top ............... 73, 149 Legislation............ 46-48

Top, False............28, 30

Regular flower............. 125

Reproduction, vegetative ...... 8 Rhus

Toxicodendron .........73, 198

Rib Grass ......21, $28, i 1 \dot{1}, 227$, f. 227

Germination ........... 41

Rice, wild................. 139

Rice-cut grass . . . . . . . . . 73, 82, 145

Roadside, Weeds.........61-62,93

Robbins, Dr................ 85

Rocky Mountain Bee Plant

Root $68,115,130,184$, f. 185 Aerial ....................... 116, 117 Annual ...........114, 115, f. 117 Biennial..............114 115 Brace................116, f. 117 Conical.............12, 116 Depth of.............12, 13 Fascicled.............. 11 Fibrous .............. 10

Fusiform ................. 116 Hair ...................... 115 Lateral . . . . . . . . . . . . . . . 10,11 Morphology of .........114-116 Multiple ............... 12 Napiform ..............116

Nodal ................. 11

Perennial .......... $8,114,115-116$

Systems ................ 10-13 Tap...............6, 10-11 Turnip-shaped ............116 Winter Annual ............114-115

Root-rot of cotton........... 5

Rootstock .................. 10 Rosa

arkansana.............73, 187 Germination .......... 42

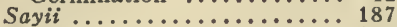

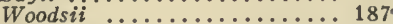

ROSACEAE $\ldots \ldots \ldots \ldots$. . . 36 , 1835

Rose...58, 64, 73, 120, f. 120, f. 129

Eradication.............. 95

Family ................ 185-187

Moss ..................... 176

Prairie ................ 187

Stems................ 4

Wild, Germination.......... 42

Rose-flowered Smartweed....... 52
Rosinweed................ 59

Rotation of Crops in destroying

Rough weeds $88-89,107,109,111,113$

Pigweed................ 13

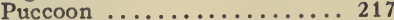

RUBIACEA E $\ldots \ldots \ldots \ldots 137,227-228$

Rubus

idaeus v. aculeatissimus..... 187

occidentalis ............. 187

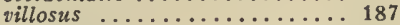

Rue, Meadow ...........29, 30. 120

Rudbeckia hirta...........13, 237

Rugel's Plantain....28, 31, f. 226, 227

Rumex Acetosella 28, 31, 33, 36, $46,53,73,164$ altissimus .........446,53,163 Legislation ............ 43 crispus

$28,33,36,46,53,69,162$, f. 163

Germination ......... 42

Legislation ............ 43

Vitality ............. 38

mexicanus ............... 163

oblusifolius ............28, 163

Patientia..............69, 163

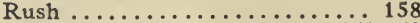
Family ............... 158-159

Purple-flowered ............ 73

Slender............. 159, f. 159

Wire.................. 73

Rush Grass

Sheathed ..............148-149

Small .................. 149

Russian Thistle $4,14,16,24,26$, $56,59,62,67,73,115,169$, $170, \mathrm{f} .170$

Weeds ................ 81

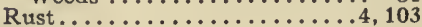

Rye

Grass

English............46,47

Italian..............46, 47

Perennial, Legislation...... 48

Perennial............... 78

Winter ................ 115

Sage ................. f. 22

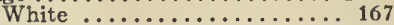

Wood $\ldots \ldots \ldots \ldots \ldots .4,12,125,218$

Sảgebrush ............... 245

St. John's wort ............. 74

Common ............203, f. 203

Family ................202-203

Salsola Kali v. tenuifolia

$56,73,169$, f. 170

Salt, common as herbicide $95,96-97,109$

Salver-form corolla.......... 127

Samara ................. 132

Sand

Briar ................ 83

Grass .................. 147

Sandbur ..........24, 73, 143-144

SAPINDACEAE . . . . . 136, 198-199

Sapling clover............, 47 


\section{Saponaria}

officinalis............68, 176

Vaccaria........28, 69, 176, f. 177

Saururus cernuus............ 160

Scarious thistle ............74, 77

Schrankia ............... 68

Scirpus

atrovirens ............... 158

validus ................ 158

Sclerospora graminicola ......... 103

\section{SCROPHULARIACEAE}

$137,223-225$

Scrophularia marilandica...... 28

Sea Blite................... 167

Secale cereale, Legislation....... 48

Sedge ....................15, 24

Broom .................. 67

Family................157 158

Seed of ................ f. 18

Seed .............133-134, f. 134

Analysis ............29-31

Analysts, American Association of . . . . . . . . 43, 49

Descriptions of Special Seeds

Alfalfa ................ f. 36

Alsike clover........... f. 35

Arrow-head ........... f. 18

Blue grass............ f. 36

Buckhorn ............. f. 34

Buckwheat .............. f. 134

Bur clover............... f. 36

Burdock ............ f. 21

Canada thistle...... $, 7, j, 26$, f. 34

Carrot, wild..........f. 25, f. 34

Chess ................. f. 23

Clover, Red............. f. 35

Cockle ............... f. 23

Cocklebur............ f. 20

Dandelion .............. f. 20

Dock, Curled............ f. 34

Dodder, Clover.......... f. 34

Foxtail ............. 17, f. 24

Green ............ f. 34

Geranium .............. f. 21

Horse Mint ........... f. 22

Licorice, Wild........... f. 20

Meadow Fescue Grass... . . f. f. 37

Orchard Grass............ f. 37

Pepper Grass, small.......f. 35

Pitchforks .............. f. 21

Plantain .............. f. 25

Bracted ............. f. 34

Rugel's ............. f. 35

Poison Ivy ........... f. 19

Quack Grass............ f. 37

Ragweed ............ 17, f. 24

Russian thistle......... f. 24

Rye Grass, English........ f. 37

Sage .................. f. 22

Sedge .............. f. 18

Sheep Sorrel ............. f. 35

Smartweed ........... 22 , f. 25

Spotted Clover............. f. 36

Sunflower .............. f. 17

Sweet clover .......... 35 , f. 36

Timothy ............ f. 35

Trefoil, Yellow........... f. 36
Page

Sced, Vegetable Oyster........ f. 17

Vetch ............. f. 21

Wheat ................ f. 23

Wood Sorrel........... f. 21

Dispersal ................ 14-26

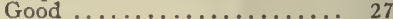

Hard-coated, Germination.... 41

Impure ..............15, 19

Impurities .............. 29

Longevity ............. 37

Chicory ................ 37

Mallow, Indian .......... 37

Mallow Family........... 36

Pulse Family............. 36

Shoofly .............. 37

Water Lily Family.......... 37

White Sweet Clover....... 37

Mucilaginous .................... 15

Purity, Standard of . . . . . . 47-49

Rough ................. 134

Shooting .............. 15, 18

Smooth ................. 134

Testing ................... 27-28

Vitality $\ldots \ldots \ldots \ldots 36-42,111-112$

Winged appendages. . . 14, 16, 134

Seedsmen's League, Wholesale.. 49

Seed Trade Association, Ameri-

can ..............43,49

Selby, A. D................. 100

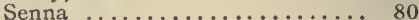

Western $\ldots \ldots \ldots \ldots \ldots \ldots \ldots . \ldots \ldots 73$

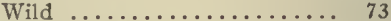

Sensitive Briar................ 68

Seploria Polygonorum......... 103

Sesbania ................. 73

macrocarpa ............. 73

Setaria

glauca ........28, 33, 56,70, 142

Germination .......... 42

Vitality ............... 38

italica ................ 28

Legislation ................. 48

verticillata .............. $70_{0,143}$

Germination ............. 42

virid is ....28, $3 \ddot{3}, 70, \ddot{14} \ddot{3}, \ddot{\mathrm{f}} .144$

Germination .......... 42

Sheathed, Rush Grass ... 148-149, 150

Sheep as weed destroyers....661, 108

Sheep Sorrel 28, 31, 33, 36, 46, 53,

Shepherd's Purse

$73,86,164$ $7,24,58,73,115,124,118$

Eradication .............. 100

Germination ................ 38

Shoestring ............ 52,58

Shoo-fly ....5, 23, 58, 87, 202, f. 202 Showy

Cinquefoil ............ 186

Milkweed ............... 209

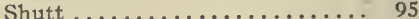

Sida $\ldots \ldots \ldots \ldots \ldots \ldots \ldots \ldots \ldots, 5,58,73$

Prickly .............. 201 spinosa ..........59, 84, 201 stipulata................ 201

Silene ................. 68 antirrhina ..................... 175

latiflora $\ldots \ldots \ldots \ldots \ldots \ldots \ldots \ldots .176$ 
Silene, noctiflora.........33,46, 176 stellata................. 29

Silique ................. 132

Silphium laciniatum........... 78

Silver Weed............73, 186

Silvery

Cinquefoil .............. 40

Nightshade ............... 72

Silybum marianum ............ 78

Distribution............. f. 79

Simple fruit............... 132

Simpson. Weed............. 28, 31

Sisymbrium

altissimum .....56, 72, 183, f. 183

officinale ...........72, f. 183

Germination .......... 42

Sium cicutaefolium........... 72

Skeleton Weed .............. 251

Skunkweed .................. 214

Sleepy

Catchfly ............... 175

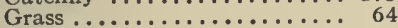

Slender

Knotweed ............. 71

Nettle ...... $7 \dot{2}, 115,16 i$, f. 161

Rush ................. 159, f. 159

Smartweed .......166-167, f. 167

Small

Barley ................ 68

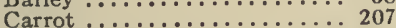

Mallow .................24, 201

Nettle .................... 162

Pepper Grass............ 180, f. 181

Ragweed 13, f. $17,26,58,59,62,73$

Rush Grass ............... 149

Small-flowered

Crowfoot ............177-178

Marsh Elder ... . . . . . . . 233-234

Smartweed f. $22,24,28,31,32$, $58,62,64,73,80,132$

Eradication..........98, 100

Muhlenberg's ............5, 165

Pennsylvania ....13, 58, 166, f. 167

Rose-flowered ........... 52

Slender..........166-167, f. 167

Smith, J. G. ............... 50

Smooth

Crab Grass 31, 33, 46, 62, 69,

$139-140$, f. 140

Dock ........43,53,67,69, 115

Tobacco ................ 74

Smothering to destroy weeds.....991

Smut

Foxtail ............... 103

Ouack Grass................. 103

Stink Grass... . . . . . . . . . . 103

Snakeroot, White............. 64

Sneezeweed .....53, 64, $733,241-242$

Narrow-leaved. $53,59,73,77,242$

Snow as seed-carrier ....... 15, 16-17

Snow-on-the-Mountain ....... 196

Snyder, D. C............... 27

Soap-berry Family........... 198-199

Soapwort . . . . . . . . . . 128, 176

Sodium arsenate as herbicide ...97-99 arsenite ..............99, 108 chlorid ...............96-97
Sodium, nitrate ......... $\begin{array}{r}\text { Page } \\ 95\end{array}$

Soils, Depletion of .............. 3-4

SOLANACEAE ........ 137, 220-222

Solanum

carolinense $54,71,83,85$, f. 221, 222

Legislation ............ 43

eleagnifolium ............ 72,222

nigrum ..........72, 220 , f. 220

rostratum ...........54, 68,78

triflorum .............. 72

Solidago

canadensis .......11, 52, 70, 231

rigida ............... 52

serotina ................ 58

Sommerville ............... 95

Sonchus

arvensis .......... 79, 252-253

asper ..................... 253

oleraceus ...... $78,79, \mathrm{f}, 252,253$

Sorghum ...............64, 139

Legislation............. 48

halapense............... 139

Sorrel ................. 67 Sheep $24,28, \cdots 3 i, \cdots 3 \dot{3}, \cdots 36$,

Yellow $46,53,58,73,86$

Sour Dock......

South American weeds $78,80,81,84$

South Dakota Weeds........68-75

Southern

Morning glory .......... 58

Nut grass ..........72, $157-158$

Poverty grass............. 51

Spear grass ................. 151

Sow thistle $24,57,58,60,63,73$,

$78,79,252-253$

Annual .........79, f. 252, 253

Field ............... 252-253

Perennial.............667, 73

Spiny-leaved............. 253

Spadix ..................... 125

Spanish

Bayonet............... 18

Bur.................... 202

Dagger.................. 13

Needle $\ldots \ldots \ldots \ldots \ldots \ldots 11$, f. 21,73

Spear grass ............... 73

Annual................. 61

Southern ................ 151

Specularia perfoliata ... . . . . . 229

Speedwell.......7, 58, 73, 115, 225

Spike................ 125, f. 125

Spiked Dropseed ............ 70

Spillman, W. J. ............ 105

Spinach ................ 167

Spines ................. 4

Spiny

Amaranth.............80, 171

Clotbur................... 74

Cocklebur ............... 59

Pigweed ................ 58

Spiny-leaved Sow Thistle...... 253

Sporobolus

neglectus.................. 149

vaginiflorus............... 148-149 
Spot disease

Crab Grass ................ 103

Smartweed .............. 103 Spotted

Spurge.......64, 74, f. 195, 196 Spurge, Large... . . . . 33, f. 194, 195

Spraying...............94-103

Ammonium sulphate......... 95

Carbolic acid ..95, 97-98, 108, 109

Copper sulphate.....90,94,95,96

Cornosive sublimate........95,99

Cost of ................. 100

Dust...................... 100

Formaldehyde............ 95, 99

Iron sulphate

$$
61,90,93,95,96,100-103,112
$$

Kerosene

Lime, slaked ................ 95, 98

Potassium sulphide.......... 95

Sodium arsenate...........99-100

Sodium arsenite. . . . . . . . 99, 108

Sodium chlorid ...........96-97

Sodium nitrate............ 95

Sulphuric acid........95,97,98

Spreading Dogbane.....64, 69, 208

Sprouting Crab Grass.......... 142

Spruce .................. 129

Spurge .........28, 31, 74, 194-198

Eradication ........... 100

Common ............... 10

Creeping................ 19. 196

Cypress .............63, 197-198

Family ................ 194-198

Flowering ............... 64

Nettle ................ 74

Spotted........64, 74, f. 195,196

Spotted, Large............ 194, 195

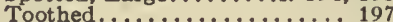

Squash $\ldots \ldots \ldots \ldots \ldots \ldots \ldots \ldots$ f. 134

Squirrel

Barley ................. 68

Grass .................... 78

Squirrel-tail Grass $\ddot{4}, \ddot{16}, \ddot{2}, \ddot{2}, \ddot{2}$, $57,58,62,67$, f. 82 $85,115,155-157$, f. 156

Distribution ............ 82

Eradication ..............111-112

Squirting Cucumber......... 15

Stamens................ 128

Diadelphous .............. 129

Gynandrous ................. 128 Star

Monadelphous .............. 129

Cucumber...............f. 119

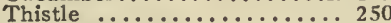

Star of Bethlehem.....61, 67, 74, 160

Steglich .................. 95

Stellaria

media .........69, 174-175, f. 174

Legislation ........... 46

Stem

Vitality .............. 38

Endogenous..........117, f. 118

Exogenous .............................. 117

Morphology of ..........116-118

Stickseed..........11, 16, 215-216

Western ..............216
Stick-tight . . . . . . . . . . 239-240

Stinging Nettle.............64, 161

Stink Grass................. 74

Stinkweed .........184-185, f. 185

Stipa................. 15

comata ................ 146

spartea...............72, 146

Western ............... 146

Stone, Mr.................. 96

Stonecrop ................ 64

Stone Fruit............... 132

Storksbill .......... 19, $57,59,74$

Stramonium, Purple ..222-223, f. 223

Strap-shaped corolla......... 128

Straw as seed carrier.......... 23

Strawberry..............f, 128

Strobile ................. 133

Strophostyles

helveola................... 191

pauciflora...........58, 68,191

Stubbleberry .......220-222, f. 220

Sub-petiolar bud ............ 117

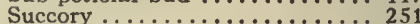

Gum.................. 251

Suckers .................. 117

Sugar

Beet ................. 167

Cane ................... 139

Maple .................. 199

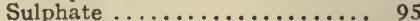

Ammonium ............... 9.5

Copper..........90,94, 95, 96

Iron $61,90,93,95,96,100-103,112$

Sulphuric acid as herbicide $95,97,98$

Summer fallow ....... 87, 93-94, 104

Sunflower...11, f. $17,51,83,128,132$

Annual................59,74

Common..........78, 238 , f. 239

Germination .......... 42

Family................... 126

Maximilian's.............. 239 Meadow

$6,52,58,62,74,239$, f. 240

Prairie..............238-239

Seed ....................... 15

Tickseed ............... 74

Western ................. 74

Superior flower.............. 127

Suspended ovule................130-131

Suture..................129-130

Dorsal .................. 129

Ventral ................. 129

Swamp

Camas ................. 64

Milkweed.............54, 209

Sweet

Clover, White 5, 6, 24, 25, 26, $28,31,42,46,47,55,56$, $58,59,74,115,189$

Clover, Yellow 46, 59, 74, 189, f. 189

Pea .................. 128

Potato........... $116,117,210$

Switch Grass............... 74

Sycamore ................................. 117

Symphoricarpos orbiculatus $71,228-229$

Symphyium officinale......... 69

Tall Buttercup............., 178 
Tanacetum vulgare .........244-245

Tanning, Weeds used in........

Tansy ............5, 64, 244-245

Tanweed ................... 74

Taproots ................ 10 11

Taraxacum officinale .....12, 69, 252

Tarred paper as weed destroyer

$107-109$

Tarweed .............59, 135 California................240-241

Tea

Yellow ................. 216

Mexican ..........58,59, 71, 80

Teasel, Fuller's........... 19,74, 115

Tecoma radicans.............. 74

Tegmen ..................... 133

Tendrils ............ $118, \mathrm{f}, 119,124$

Terminal bud.............. 117

Testa..................... 133

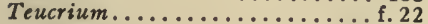

canadense.................

Texas

occidentale.............218-219

Croton

69

Weeds $\ldots \ldots \ldots . . .668 .75$

Thalictrum purpurascens........ 29

Thistle ........18, 25, 28, 57,67

Bull 7,10, f. $16,23,26,28,30$, $52,62,67,74,77,79,83$ $86,90,115,246-247$, f. 248

Eradication...100, 108, 109, 110

Germination .......... 42

Canada $7,8,16,19,25,27,28$, $30,46,52,57,58,60,62$, $65,66,67,74,78,79,83$, $115,248,250$, f. 249

Distribution ........... 79

Extermination $95,96,98,99,103$

Legislation ............ 43

Family ............... 229-254

Field . . . . . . . . . . . . 10, 13

Iowa................... 52

Milk ................ 59

Nelson's................... 14 , 15

Prairie.................. 247-248

Russian $4,14,16,24,20,56$,

Scarious $\quad 59,62,67,73,115$

Sow $24,57,58,60,735,78,79$.

252-253

Annual.........79, 253, f. 252

Eradication........100,107-108

Field ...............252-253

Perennial............6.67,73

Spiny-leaved ............. 253

Woolly....f. 8, $\dot{5} 9,62,74, \ddot{1} \dot{6}, 247$

Thlaspi arvense +.....179-180, f. 180

Germination ........... 40

Thornapple ............... 74

Thorny Pigweed.............. 73

Thoroughwort ......... $74,230-231$

Three-flowered Nightshade.... 72

Three-seeded Mercury ......... 74

Thuja occidentalis, Vitality of ... 38

Tickseed ................ 240

Sunflower ................ 74

Trk Trefoil ............... 18
Page

Timothy .............28, 31, 33

Legislation .............. 48

Meadows, weeds in.......67, 116

Wild ................. 148

Eradication ............. 110

Toadflax ............58, 60,224

Toadstool ................ 64

Tobacco...............64, 225

Smooth ................ 74

Tomato.............. 127,225

Toothed

Medick ................. 190

Spurge ..................... 197

Toumey ............... 51

Tracy ................. 55

Tragopogon porrifolius ........... 72

Treacle Mustard ............ 183

Tread-softly ................ 193

Tree of heaven .............. 64

Trefoil .................... 28

Yellow $\ldots \ldots \ldots \ldots \ldots \ldots \ldots \ldots \ldots . \ldots \ldots$

Legislation $\ldots \ldots \ldots \ldots \ldots \ldots .46,47$

Tribulus terrestris......... 193, f. 193

Trifolium

agrarium.............669, 190

hybridum .................. 29, 33

Legislation ............ 47

incarnatum, Legislation........ 47

pratense............... 29

Germination ............ 42

Legislation. . . . . . . . . .46,47

procumbens ..........69, 189-190

repens................29, 33

Germination............42, 48

Legislation ............ 48

Triticum

Vitality .............. 38

Legislation ............ 48

sativum, Germination ......... 42

Truman, H. L............. 85

Trumpet Creeper ............74, 116

Honeysuckle .............. 128

Tubular corolla................ 128

Tumbleweed

$13,14, f, 15,16,28,33,171$

Western .............. 167

Tumbling Mustard

$26,56,57,72,115,183$, f. 183

Turkey-foot grass............ 59

Turnip $\ldots \ldots \ldots \ldots \ldots \ldots \ldots \ldots . \ldots 116$

Turnip-shaped Root.............. 116

Two-lipped corolla............. 128

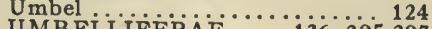

UMB ELLIFERAE … . . 136, 205-207

Umbrella Plant............ 172-173

Unicorn Plant.................. 74

Urena lobata.................. 202

Urtica

dioica ............... 161

gracilis............. $72, i 6 i$, f, 161

holosericea............... 72, 162

urens................ 72,162

URTICACEAE.......... $\ddot{135}, 160-162$

Ustilago neglecta............... 103

Utah, weeds in ...............68-75

Utricle $\ldots \ldots \ldots \ldots \ldots \ldots \ldots \ldots \ldots 132$

Vacant Lots, Weeds of ..........60-61 
Page

Vanilla Grass . . . . . . . 75, 145-146 Velvet

Dock ................... 224

Grass .................... $36,75,78$

Velvet-leaf.....26, 27, $31,200, f, 200$ Eradication ............. 100

Velvet Weed . . 24, 58, 62, 67, 74, 115 Legislation ............... 100

Ventral suture ............... 129

Venus' Looking-glass... . . . . . . . . 229

Veratrum viride ............ 57

Verbascum

Blattaria ............... 224

Thapsus............... 71, 224

Vitality .............. 38

Verbena

angustifolia ............217-218

bracleosa ................. 74

Family ................. 217-218

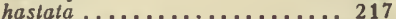

Narrow-leaved............. 217-218

stricla. . .29, 31, 54, 74, 217, f. 218

urlicaefolia.........29, 75, 218

Vernonia ................ 52

altissima .............. 230

Baldwinii...................... f30, 230

fasciculata ................ 230

noveboracensis.........58, 7i, 230

Veronica peregrina........ 73, 225

Versatile filament............. 129

Vervain................29, 31 Blue.........33, 54, 74, 88,217 Bracted .................. 74 Hoary ............217, f. 218 Nettle ............... 75 White................... 218

Vetch ...... $5,15,23, \overline{5} 7, \dot{5} 8,75,115$

Common.............190-191

Vicia sativa...........75, 190-191

VIOLACEAE. . . . . . . . . 136, 203-204

Violet Family ..............203-204

Virginia

Creeper ................. 120

Garden weeds............. 59

Pepper Grass ............. 72

Plantain .............. 59

Voelcker ................... 95

Waldron, L. R.............. 38

Washington, weeds .........68-75 Water

Chinquapin .............. 15

Hemlock........64, 206, f. 207

Hemp................27,31

Horehound ................. 42

Hyacinth, Distribution of $f$. 79,84

Parsnip.............4, 64,72

Pepper................24, 166

Water, Seeds scattered by $15,17, f .18$

Waterleaf ............... 215

Family ................214-215

Water-weed ............... 84

Webber, H. J................. 84

Weed-killers, Commercial........ 95

Weeds

Characters of ............ 66

Cosmopolitan ............ 60
Weage

Descriptions of .........

Duration of ............... 7

Eradication of ..........87-113

Injuriousness of ............ 1-26

Lines of travel of ........... $81-86$

Migration of .........60-61, 76-86

Morphology of ...........114-134

Noxious in

Indiana ............. 67

Iowa .................66-67

Kentucky .............. 67

Manitoba .............. 67

North Dakota........... 67

Ohio .................. 67

West Virginia........... 67

Wisconsin .............. 67

Wyoming ............ 67

Origin of ............... $76-81$

Poisonous .....4, $53,54,57,63-64$

Replaced by allied species.... 76

Scale of points in judging ..... 66

Spreading ............. . . . 16

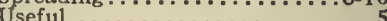

Western

Cowbane ............... 55

Larkspur ................ 71

Milkweed ............... 71

Mugwort.................7i, 245

Nettle............ 72, 116, 162

Ragweed..........39, 40, 234-235

Senna ................ 73

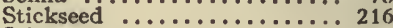

Stipa ................... 146

Sunflower ............. 74

Wormwood $\ldots \ldots \ldots \ldots \ldots \ldots \ldots \ldots 7 . \ldots . \ldots 75$

West Virginia weeds......... 67

Wheat..........17, 95, 139, 189

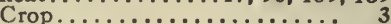

Germination .............. 42

Legislation ................ 48

Winter ............................ 115

Wheel-shaped corolla........127, f. 127

White

Aster................. 231-232

Small-flowered .......... 232

Avens.... . . . . . . . . . . . 68, 186

Clover...............29, 31, 33

Cockle .................. 46

Dock ..................... 153

Milkweed...............2099-210

Sage ..................... 167

Snakeroot ................. 64

Sweet Clover $5,6,24,23,26$, $28,31,42,55,56,58,59$,

$74,115,189$

Vervain ...............13, 218

White-leaved Franseria.......... 235

Whiteweed ....52, f. 53, 67,232, f. 232

Whorled Foxtail........... 42

Wild

Artichoke ............... 6

Barley

$4,57,59,64,78,111-112,115$

Bean............58, 68, 191

Black Cherry................. 64

Blackberry ............. 26 
Chamomile ............. 69

Four-o'clocl $\ldots \ldots \ldots \ldots \ldots, 9,67,70$

Heliotrope..$\ldots \ldots \ldots \ldots \ldots \ldots$. 59

Hemp................. 13

Indigo $\ldots \ldots \ldots \ldots \ldots \ldots \ldots \ldots, 64$

Leek ................ 72

Lettuce............. 126, 254

Licorice............ 20,59, 71, 116

Morning Giory

24, 26, f. 113, 211-212 f. 212

Mustard.....31, 38, 43, 46, 66, 76

Oats ....18, 19, 31, 46, 57, 58,

$64,67,149-150$

Onion.............9,59,72

Parsnip.....i1, 26, 67, $72,206-207$

Pepper grass.............33, 42

Poppy ................... 116

Potato ................ 211

Radish ................... 24

Raspberry $\mathrm{Red} . \ldots \ldots \ldots \ldots \ldots \ldots, 187$

Rice .................. 139

Rose................... 42

Senna ............... 73

Timothy.............110, ii6, 138

Willow

Willow-herb, Great............ 204

Willow-leaved Aster............ 232

Wilson $\ldots \ldots \ldots \ldots \ldots \ldots \ldots .95$

Wind as seed-carrier .........14, 16-17

Wind-flower .............. 63

Wing, J. E.................. 89

Winged Pigweed......... 15, 167, 168

Winter

Annual................... 115

Cress..$\ldots \ldots \ldots \ldots \ldots \ldots \ldots \ldots \ldots .184$

Wire

Rye ................. 115

Grass ......24, 150-151, f. 150, 152

Rush .................... 73

Wisconsin weeds ..........67,68-75

Witch Grass .....28, 31, $75,141-142$

Wood

Nettre. ... . .......... 72

Sage........... $12,125,218$

Wood-sorrel..................f. 21

Family $. . \ldots \ldots \ldots \ldots \ldots \ldots . . .191$

Yellow ................. 191

Wool as seed-carter......... 19

Woolly Thistle......... $8, \mathrm{ii6}, 247$

Wormseed..............64, 183

Wormwood $\ldots \ldots \ldots \ldots \ldots \ldots \ldots \ldots .245$

Biennial............... 75

Western ................ 75

Wright's Jimson Weed......... 71

Xanthium

canadense .....69, 235-236, £. 238

Germination ......... 42

Legislation ............ 42

spinosum................. 74,236

Yards, Weeds of ...........62, 93

Extermination .............. 93

Yarrow..........67, 75, 116, 243

Yellow

Burweed ............... 216

Clover....................69, 190

Fireweed ............ 70

Foxtail ......24, 33, 62, 70, 142

Goldenrod ............. 52

Lady's Slipper .............. 64

Oxalis................... 13

Sorrel .............. 18

Sweet Clover.......59, $\mathbf{7 4}, \mathbf{1 8 9}, \mathbf{f}, 189$

Tarweed ................ 216

Trefoil ...........31, $33,46,47$

Wood Sorrel .............. 191

Yellow-flowered Goidenrod..... 52

Yerba Mansa............. 160

Yew .................. 64

Legislation .............. 48

Zealand, New

Seed $. \ldots \ldots \ldots \ldots \ldots \ldots \ldots, 36$

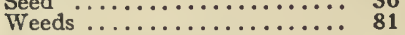

Zea Mays, Germination of ...... 42

Lerislation............... 48

ZYGOPHYLLACEAE . . 136, 192-193 



\section{STAANDARD BOOKS}

PUBLISHED BY

\section{ORANGE JUDD COMPANY}

NEW YORK

Ashland Building

315-321 Fourth Avenue
CHICAGO

People's Gas Building 150 Michigan Avenue

Any of these books will be sent by mail, postpaid, to. any part of the world, on receipt of catalog price. We are always happy to correspond with our patrons, and cordially invite them to address us on any matter pertaining to rural books. Send for our large illustrated catalog, free on application.

\section{First Principles of Soil Fertility}

By Alfren Vivian. There is no subject of more vital importance to the farmer than that of the best method of maintaining the fertility of the soll. The very evident decrease in the fertility of those soils which have been under cultivation for a number of years, combined with the increased competition and the advanced price of labor, have convinced the intelligent farmer that the agriculture of the future must be based upon more rational practices than those which have been followed in the past. We have felt for some time that there was a place for a brief, and at the same time comprehensive, treatise on this important subject of Soil Fertility. Professor Vivian's experience as a teacher in the short winter courses has admirably fitted him to present this matter in a popular style. In this little book he has given the gist of the subject in plain language, practically devoid of technical and scientific terms. It is pre-eminently a "First Book," and will be found especially valuable to those who desire an introduction to the subject, and who intend to do subsequent reading. Illustrated. $5 \times 7$ inches. 265 pages. Cloth. Net, $\$ 1.00$

\section{The Study of Corn}

By Prof. V. M. Shoesmith. A most helpful book to all farmers and students interested in the selection and improvement of corn. It is profusely illustrated from photographs, all of which carry their own story an' contribute their part in making pictures and text matter a clear, concise and interesting study of corn. Illustrated. $5 \times 7$ inches. I00 pages. Cloth. . . . . . . . . Net, \$0.50 
By Charles William Burkett, Director Kansas Agricultural Experiment Station. The most complete and popular work of the kind ever published. As a rule, a book of this sort is dry and uninteresting, but in this case it reads like a novel. The author has put into it his individuality. The story of the properties of the soils, their improvement and management, as well as a discussion of the problems of crop growing and crop feeding, make this book equally valuable to the farmer, student and teacher. Illustrated. 303 pages. $51 / 2 \times 8$ inches. Cloth. . Net, \$1.25

\section{Weeds of the Farm Garden}

By L. H. PAMmel. The enormous losses, amounting to several hundred million dollars annually in the United States, caused by weeds stimulate us to adopt a better system of agriculture. The weed question is, therefore, a most important and vital one for American farmers. This treatise will enable the farmer to treat his field to remove weeds. The book is profusely illustrated by photograplis and drawings made expressly for this work, and will prove invaluable to every farmer, land owner, gardener and park superintendent. $5 \times 7$ inches. 300 pages. Cloth.

\section{Farm Machinery and Farm Motors}

By J. B. Davidson and L. W. Chase. Farm Machinery and Farm Motors is the first American book published on the subject of Farm Machinery since that written by J. J. Thomas in 1867. This was before the development of many of the more important farm machines, and the general application of power to the work of the farm. Modern farm machinery is indispensable in present-day farming operations, and a practical book like Farm Machinery and Farm Motors will fill a much-felt need. The book has been written from lectures used by the authors before their classes for several years, and which were prepared from practical experience and a thorough review of the literature pertaining to the subject. Although written primarily as a text-book, it is equally useful for the practical farmer. Profusely illustrated. $5 \frac{1}{2} \times 8$ inches. 520 pages. Cloth. . . . . . . . . . . Net, $\$ 2.00$

\section{The Book of Wheat}

By P. T. Dondlinger. This book umprises a complete study of everything pertaining to wheat. It is the work of a student of economic as well as agricultural conditions, well fitted by the broad experience in both practical and theoretical lines to tell the whole story in a condensed form. It is designed for the farmer, the teacher, and the student as well. Illustrated. $51 / 2 \times 8$ inches. 370 pages. Cloth. . . . . . . . . . Net, $\$ 2.00$ 


\section{The Cereals in America}

By Thomas F. Hunt, M.S., D.Agri., Professor of Agronomy, Cornell University. If you raise five acres of any kind of grain you cannot afford to be without this book. It is in every way the best book on the subject that has ever been written. It treats of the cultivation and improvement of every grain crop raised in America in a thoroughly practical and accurate manner. The subject-matter includes a comprehensive and succinct treatise of wheat, maize, oats, barley, rye, rice, sorghum (kafir corn) and buckwheat, as related particularly to American conditions. First-hand knowledge has been the policy of the author in his work, and every crop treated is presented in the light of individual study of the plant. If you have this book you have the latest and best that has been written upon the subject. Illustrated. 450 pages. $5 \frac{1}{2} \times 8$ inches. Cloth.

\section{The Forage and Fiber Crops in America}

By Thomas F. Hunt. This book is exactly what its title indicates. It is indispensable to the farmer, student and teacher who wishes all the latest and most important information on the subject of forage and fiber crops. Like its famous companion, "The Cereals in America," by the same author, it treats of the cultivation and improvement of every one of the forage and fiber crops. With this book in hand, you have the latest and most up-to-date information available. Illustrated. 428 pages. $5^{1 / 2} \times 8$ inches. Cloth. . . . . $\$ 1.75$

\section{The Book of Alfalfa}

History, Cultivation and Merits. Its Uses as a Forage and Fertilizer. The appearance of the Hon. F. D. CoBurn's little book on Alfalfa a few years ago has been a profit revelation to thousands of farmers throughout the country, and the increasing demand for still more information on the subject has induced the author to prepare the present volume, which is by far the most authoritative, complete and valuable work on this forage crop published anywhere. It is printed on fine paper and illustrated with many full-page photographs that were taken with the especial view of their relation to the text. 336 pages. $6 \frac{1 / 2}{2} \times 9$ inches. Bound in cloth, with gold stamping. It is unquestionably the handsomest agricultural reference book that has ever been issued. Price, postpaid, . $\$ 2.00$

\section{Clean Milk}

By S. D. Belcher, M.D. In this book the author sets forth practical methods for the exclusion of bacteria from milk, and how to prevent contamination of milk from the stable to the consumer. Illustrated. $5 \times 7$ inches. 146 pages. Cloth. 


\section{Bean Culture}

By Glenn C. Sevey, B.S. A practical treatise on the production and marketing of beans. It includes the manner of growth, soils and fertilizers adapted, best varieties, seed selection and breeding, planting, harvesting, insects and fungous pests, composition and feeding value; with a special chapter on markets by Albert W. Fulton. A practical book for the grower and student alike. Illustrated. I44 pages. $5 \times 7$ inches. Cloth. . . . . . . . . . . . \$0.50

\section{Celery Culture}

By W. R. Beattie. A practical guide for beginners and a standard reference of great interest to persons already engaged in celery growing. It contains many illustrations giving a clear conception of the practical side of celery culture. The work is complete in every detail, from sowing a few seeds in a window-box in the house for early plants, to the handling and marketing of celery in carload lots. Fully illustrated. I50 pages. $5 \times 7$ inches. Cloth. . . . . . \$ \$0.50

\section{Tomato Culture}

By Will W. Tracy. The author has rounded up in this book the most complete account of tomato culture in all its phases that has ever been gotten together. It is no secondhand work of reference, but a complete story of the practical experiences of the best-posted expert on tomatoes in the world. No gardener or farmer can afford to be without the book. Whether grown for home use or commercial purposes, the reader has here suggestions and information nowhere else available. Illustrated. I 50 pages. $5 \times 7$ inches. Cloth. $\$ 0.50$

\section{The Potato}

By Samuel Fraser. This book is destined to rank as a standard work upon Potato Culture. While the practical side has been emphasized, the scientific part has not been neglected, and the information given is of value, both to the grower and to the student. Taken all in all, it is the most complete, reliable and authoritative book on the potato ever published in America. Illustrated. 200 pages. $5 \times 7$ inches. Cloth. . . \$0.75

\section{Dwarf Fruit Trees}

By F. A. WaUGh. This interesting book describes in detail the several varieties of dwarf fruit trees, their propagation, planting, pruning, care and general management. Where there is a limited amount of ground to be devoted to orchard purposes, and where quick results are desired, this book will meet with a warm welcome. Illustrated. II2 pages. $5 \times 7$ inches. Cloth. . . . . . . . . . . . \$0.50 


\section{Cabbage, Cauliflower and Allied Vegetables}

By C. L. Allen. A practical treatise on the various types and varieties of cabbage, cauliflower, broccoli, Brussels sprouts, kale, collards and kohl-rabi. An explanation is given of the requirements, conditions, cultivation and general management pertaining to the entire cabbage group. After this each class is treated separately and in detail. The chapter on seed raising is probably the most authoritative treatise on this subject ever published. Insects and fungi attacking this class of vegetables are given due attention. Illustrated. I26 pages. $5 \times 7$ inches. Cloth. . . . . . . . \$0.50

\section{Asparagus}

By F. M. Hexamer. This is the first book published in America which is exclusively devoted to the raising of asparagus for home use as well as for market. It is a practical and reliable treatise on the saving of the seed, raising of the plants, selection and preparation of the soil, planting, cultivation, manuring, cutting, bunching, packing, marketing, canning and drying, insect enemies, fungous diseases and every requirement to successful asparagus culture, special emphasis being given to the importance of asparagus as a farm and money crop. Illustrated. I74 pages. $5 \times 7$ inches. Cloth. . \$o.50

\section{The New Onion Culture}

By T. Greiner. Rewritten, greatly enlarged and brought up to date. A new method of growing onions of largest size and yield, on less land, than can be raised by the old plan. Thousands of farmers and gardeners and many experiment stations have given it practical trials which have proved a success. A complete guide in growing onions with the greatest profit, explaining the whys and wherefores. Illustrated. $5 \times 7$ inches. I40 pages. Cloth. . . . . . . \$0.50

\section{The New Rhubarb Culture}

A complete guide to dark forcing and field culture. Part I-By J. E. Morse, the well-known Michigan trucker and originator of the now famous and extremely profitable new methods of dark forcing and field culture. Part II-Compiled by G. B. FISKE. Other methods practiced by the most experienced market gardeners, greenhouse men and experimenters in all parts of America. Illustrated. 130 pages. $5 \times 7$ inches. Cloth. . . . . . . . . . \$0.50 


\section{Alfalfa}

By F. D. CoBurn. Its growth, uses, and feeding value. The fact that alfalfa thrives in almost any soil; that without reseeding, it goes on yielding two, three, four, and sometimes five cuttings annually for five, ten, or perhaps 100 years; and that either green or cured it is one of the most nutritious forage plants known, makes reliable information upon its production and uses of unusual interest. Such information is given in this volume for every part of America, by the highest authority. Illustrated. 164 pages. $5 \times 7$ inches. Cloth. \$o.50

\section{Ginseng, Its Cultivation, Harvesting, Marketing and Market Value}

By MaUrice G. KarNs, with a short account of its history and botany. It discusses in a practical way how to begin with either seeds or roots, soil, climate and location, preparation planting and maintenance of the beds, artificial propagation, manures, enemies, selection for market and for improvement, preparation for sale, and the profits that may be expected. This booklet is concisely written, well and profusely illustrated, and should be in the hands of all who expect to grow this drug to supply the export trade, and to add a new and profitable industry to their farms and gardens, without interfering with the regular work. New edition. Revised and enlarged. Illustrated. $5 \times 7$ inches. Cloth. . . . . \$0.50

\section{Landscape Gardening}

By F. A. WAUGH, professor of horticulture, university of Vermont. A treatise on the general principles governing outdoor art; with sundry suggestions for their application in the commoner problems of gardening. Every paragraph is short, terse and to the point, giving perfect clearness to the discussions at all points. In spite of the natural difficulty of presenting abstract principles the whole matter is made entirely plain even to the inexperienced reader. Illustrated. 152 pages. $5 \times 7$ inches. Cloth. . . . . . . . \$0.50

\section{Hedges, Windbreaks, Shelters and Live Fences}

By E. P. Powell. A treatise on the planting, growth and management of hedge plants for country and suburban homes. It gives accurate directions concerning hedges; how to plant and how to treat them; and especially concerning windbreaks and shelters. It includes the whole art of making a delightful home, giving directions for nooks and balconies, for bird culture and for human comfort. Illustrated. I 40 pages. $5 \times 7$ inches. Cloth. . . . . . . . \$0.50 


\section{Farm Grasses of the United States of America}

By William Jasper Spillman. A practical treatise on the grass crop, seeding and management of meadows and pastures, description of the best varieties, the seed and its impurities, grasses for special conditions, lawns and lawn grasses, etc., etc. In preparing this volume the author's object has been to present, in connected form, the main facts concerning the grasses grown on American farms. Every phase of the subject is viewed from the farmer's standpoint. Illustrated. 248 pages. $5 \times 7$ inches. Cloth. . . . \$1.00

\section{The Book of Corn}

By Herbert Myrick, assisted by A. D. Shambia, E. A. Burnett, Alber' W. Fulton, B. W. Snow, and other most capable specialists. A complete treatise on the culture, marketing and uses of maize in America and elsewhere for farmers, dealers and others. Illustrated. 372 pages. $5 \times 7$ inches. Cloth. . . . . . . . . . . \$1.50

\section{The Hop-Its Culture and Care, Marketing and Manufacture}

By Herbert Myrick. A practical handbook on the most approved methods in growing, harvesting, curing and selling hops, and on the use and manufacture of hops. The result of years of research and observation, it is a volume destined to be an authority on this crop for many years to come. It takes up every detail from preparing the soil and laying out the yard, to curing and selling the crop. Every line represents the ripest judgment and experience of experts. Size, $5 \times 8$; pages, 300; illustrations, nearly I50; bound in cloth and gold; price, postpaid. . . . . . . . . . \$I.50

\section{Tobacco Leaf}

By J. B. Killebrew and Herbert Myrick. Its Culture and Cure, Marketing and Manufacture. A practical handbook on the most approved methods in growing, harvesting, curing, packing and selling tobacco, with an account of the operations in every department of tobacco manufacture. The contents of this book are based on actual experiments in field, curing barn, packing house, factory and laboratory. It is the only work of the kind in existence, and is destined to be the standard practical and scientific authority on the whole subject of tobacco for many years. 506 pages and 150 original engravings. $5 \times 7$ inches. Cloth. . . . . . . . $\$ 2.00$ 


\section{Bulbs and Tuberous-Rooted Plants}

By C. L. Allen. A complete treatise on the history, description, methods of propagation and full directions for the successful culture of bulbs in the garden, dwelling and greenhouse. The author of this book has for many years made bulb growing a specialty, and is a recognized authority on their cultivation and management. The cultural directions are plainly stated, practical and to the point. The illustrations which embellish this work have been drawn from nature and have been engraved especially for this book. 312 pages. $5 \times 7$ inches. Cloth. . . . \$1.50

\section{Fumigation Methods}

By Willis G. Johnson. A timely up-to-date book on the practical application of the new methods for destroying insects with hydrocyanic acid gas and carbon bisulphid, the most powerful insecticides ever discovered. It is an indispensable book for farmers, fruit growers, nurserymen, gardeners, florists, millers, grain dealers, transportation companies, college and experiment station workers, etc. Illustrated. 313 pages. $5 \times 7$ inches. Cloth. . . . . \$1.00

\section{Diseases of Swine}

By Dr. R. A. Craig, Professor of Veterinary Medicine at the Purdue University. A concise, practical and popular guide to the prevention and treatment of the diseases of swine. With the discussions on each disease are given its causes, symptoms, treatment and means of prevention. Every part of the book impresses the reader with the fact that its writer is thoroughly and practically familiar with all the details upon which he treats. All technical and strictly scientific terms are avoided, so far as feasible, thus making the work at once available to the practical stock. raiser as well as to the teacher and student. Illustrated. $5 \times 7$ inches. I90 pages. Cloth. \$0.75

\section{Spraying Crops-Why, When and How}

By Clarence M. Weed, D.Sc. The present fourth edition has been rewritten and set throughout to bring it thoroughly up to date, so that it embodies the latest practical information gleaned by fruit growers and experiment station workers. So much new information has come to light since the third edition was published that this is practically a new book, needed by those who have utilized the earlier editions, as well as by fruit growers and farmers generally. Illustrated. I36 pages. $5 \times 7$ inches. Cloth. . . . . . . . \$0.50 


\section{Successful Fruit Culture}

By Samuel T. Maynard. A practical guide to the cultivation and propagation of Fruits, written from the standpoint of the practical fruit grower who is striving to make his business profitable by growing the best fruit possible and at the least cost. It is up-to-date in every particular, and covers the entire practice of fruit culture, harvesting, storing, marketing, forcing, best varieties, etc., etc. It deals with principles first and with the practice afterwards, as the foundation, principles of plant growth and nourishment must always remain the same. while practice will vary according to the fruit grower's immediate conditions and environments. Illustrated. 265 pages. $5 \times 7$ inches. Cloth. . . . . . . . \$1.00

\section{Plums and Plum Culture}

By F. A. Waugh. A complete manual for fruit growers, nurserymen, farmers and gardeners, on all known varieties of plums and their successful management. This book marks an epoch in the horticultural literature of America. It is a complete monograph of the plums cultivated in and indigenous to North America. It will be found indispensable to the scientist seeking the most recent and authoritative information concerning this group, to the nurseryman who wishes to handle his varieties accurately and intelligently, and to the cultivator who would like to grow plums successfully. Illustrated. 39I pages. $5 \times 7$ inches. Cloth. . . . . \$1.50

\section{Fruit Harvesting, Storing, Marketing}

By F. A. Waugr. A practical guide to the picking, storing, shipping and marketing of fruit. The principal subjects covered are the fruit market, fruit picking, sorting and packing, the fruit storage. evaporation, canning, statistics of the fruit trade, fruit package laws, commission dealers and dealing, cold storage, etc., etc. No progressive fruit grower can afford to be without this most valuable book. Illustrated. 232 pages. $5 \times 7$ inches. Cloth. . . . . . . \$1.00

\section{Systematic Pomology}

By F. A. WaUgh, professor of horticulture and landscape gardening in the Massachusetts agricultural college, formerly of the university of Vermont. This is the first book in the English language which has ever made the attempt at a complete and comprehensive treatment of systematic pomology. It presents clearly and in detail the whole method by which fruits are studied. The book is suitably illustrated. 288 pages. $5 \times 7$ inches. Cloth. . . . . . . . \$1.00 


\section{Greenhouse Construction}

By Prof. L. R. TAFT. A complete treatise on greennouse structures and arrangements of the various forms and styles of plant houses for professional florists as well as amateurs. All the best and most approved structures are so fully and clearly described that any one who desires to build a greenhouse will have no difficulty in determining the kind best suited to his purpose. The modern and most successful methods of heating and ventilating are fully treated upon. Special chapters are devoted to houses used for the growing of one kind of plants exclusively. The construction of hotbeds and frames receives appropriate attention. Over 100 excellent illustrations, especially engraved for this work, make every point clear to the reader and add considerably to the artistic appearance of the book. 210 pages. $5 \times 7$ inches. Cloth. \$1.50

\section{Greenhouse Management}

By L. R. TAFT. This book forms an almost indispensable companion volume to Greenhouse Construction. In it the author gives the results of his many years' experience, together with that of the most successful florists and gardeners, in the management of growing plants under glass. So minute and practical are the various systems and methods of growing and forcing roses, violets, carnations, and all the most important florists' plants, as well as fruits and vegetables described, that by a careful study of this work and the following of its teachings, failure is almost impossible. Illustrated. 382 pages. $5 \times 7$ inches. Cloth. . . . . . . . . \$1.50

\section{Fungi and Fungicides}

By Prof. Clarence M. Weed. A practical manual concerning the fungous diseases of cultivated plants and the means of preventing their ravages. The author has endeavored to give such a concise account of the most important facts relating to these as will enable the cultivator to combat them intelligently. 90 illustrations. 222 pages. $5 \times 7$ inches. Paper, 5o cents; cloth . . . . . . . . . \$1.00

\section{Mushrooms. How to Grow Them}

By William Falconer. This is the most practical work on the subject ever written, and the only book on growing mushrooms published in America. The author describes how he grows mushrooms, and how they are grown for profit by the leading market gardeners, and for home use by the most successful private growers. Engravings drawn from nature expressly for this work. I70 pages. $5 \times 7$ inches. Cloth. \$1.00 



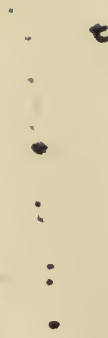

$=$

$\div$

$-$ 


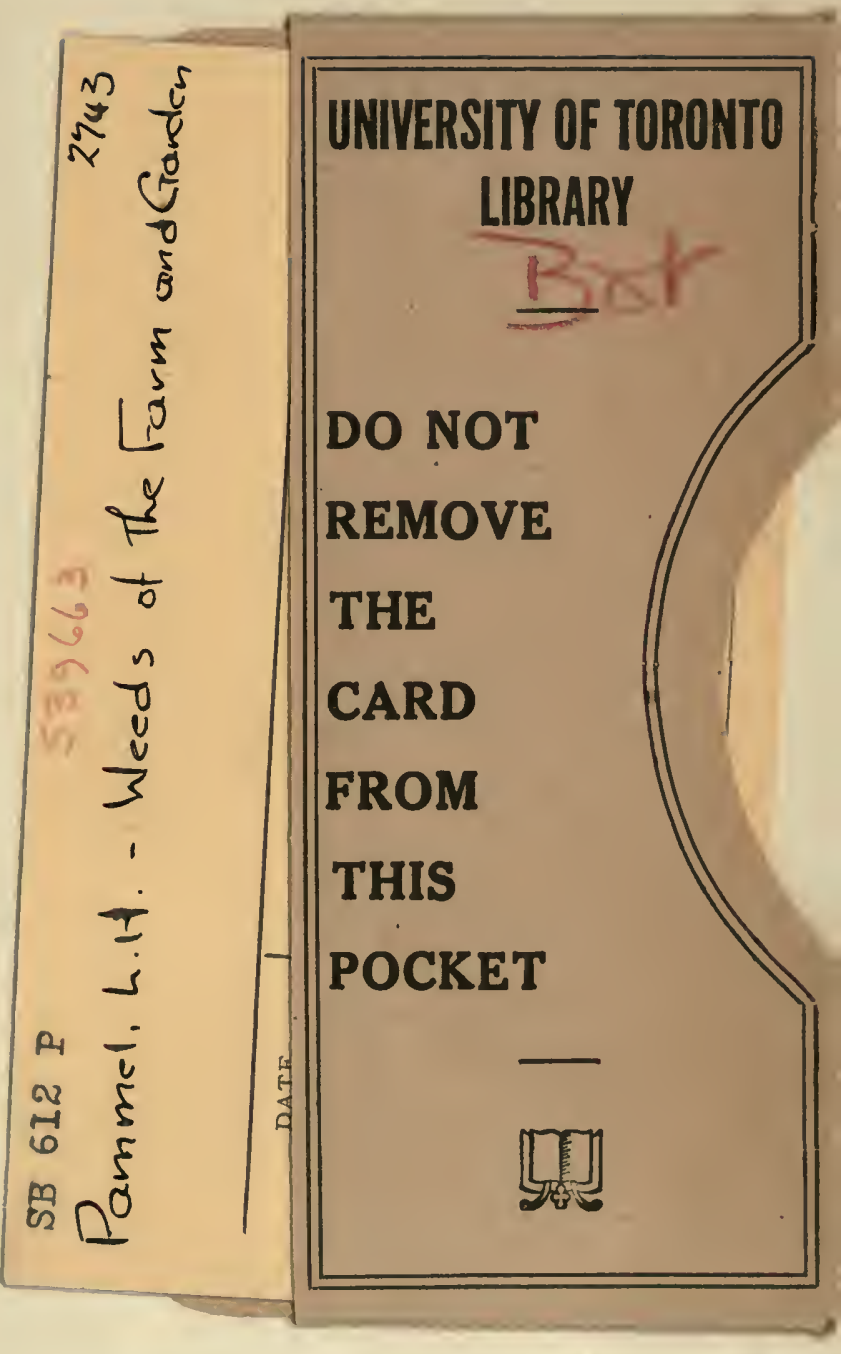




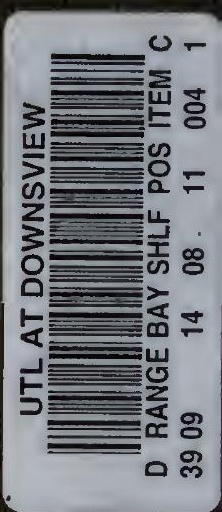

